Amanda Maria Tadini

\title{
GÊNESES DE ESPODOSSOLOS AMAZÔNICOS: UM ESTUDO SOBRE A ESTRUTURA E A MOBILIDADE DA MATÉRIA ORGÂNICA
}




\section{Gêneses de Espodossolos Amazônicos: um estudo sobre a estrutura e a mobilidade da Matéria Orgânica}

Trabalho apresentado para obtenção do título (dupla titulação), no âmbito do Convênio Acadêmico Internacional para Coorientação de Tese de Doutorado celebrado pelo Instituto de Química de São Carlos, Universidade de São Paulo, Brasil e a Université de Toulon, França.

Área de Concentração: Química Analítica e Inorgânica

Orientador no Brasil: Dra. Débora Marcondes Bastos Pereira Milori Orientador na França: Dr. Stéphane Mounier Processo FAPESP: 2013/13013-3 
Dedico a Deus por iluminar e guiar meus passos nessa caminhada. Em especial, aos meus pais, Maria de Lourdes e Walter Tadini, pelo amor, exemplo de vida e caráter, principalmente, por tudo que fizeram por mim ao longo da minha vida, sempre incentivando à nunca desistir dos nossos sonhos. Ao meu querido irmão, Waltinho, pelo carinho e amor. 


\section{Agradecer}

丸̀ Deus, pela força e coragem durante toda esta longa jornada.

$\mathcal{A}$ Professora Dra. Débora Marcondes Bastos Pereira Milori da Embrapa Instrumentação, pela orientação, ensinamentos, atenção, dedicação e, principalmente pela amizade e confiança, durante esses anos de Doutorado.

Ao Professor Dr. Stéphane Mounier da Université de Toulon, pela orientação, dedicação, oportunidade de fazer um Doutorado em Cotutela pela Université de Toulon, pelo apoio que me foi dado durante um ano em que passei em seu laboratório, e príncipalmente pela amizade durante esses anos.

$\mathcal{A}$ Professora Dra. Célía Regina Montes do Centro de Energía Nuclear na Agrícultura (USP-Piracícaba), pelas conversas e consethos a respeito da regiáo de estudo, e principalmente por ter cedido às amostras dos solos Amazônicos para o desenvolvimento do Doutorado.

Ao Professor Dr. Wilson Tadeu Lopes da Sílva da Embrapa Instrumentação, pela ajuda no planejamento para a extração das substâncias húmicas, príncípalmente da puríficação dos ácídos fúlvicos, e também pelas conversas e conselhos dados durante o desenvolvimento do projeto.

Ao Dr. Gustavo Nícolodelli, pela amizade, ensinamentos, conselhos, contribuições e colaborações dados durante o desenvolvimento do Doutorado.

Ao Dr. Yves Lucas da Université de Toulon, pelas conversas, conselhos e sugestões a respeito dos solos Amazônicos, dados durante a minha estadia na França no laboratório PROTEE. 
Ao Dr. Paulino Ribeíro Villas-Boas da Empraba Instrumentação pela colaboração e sugestões dados durante o desenvolvimento do Doutorado.

Ao Dr. Houssam Hajjoul e Dr. Roland da Université de Toulon, Campus La Garde, que ajudaram e auxiliaram nas análises de Espectroscopia de Fluorescêncía Resolvida no Tempo, durante a minha estadia na França.

ג̇ Fundação de Amparo à Pesquísa do Estado de São Paulo (FAPESP), pelo apoio financeiro e pela bolsa concedida (Processo: 2013/13013-3), imprescindível para realização desse projeto.

Ao Conselho Nacional de Desenvolvimento Científico e Tecnologico $(C \mathcal{N} P q)$ pela bolsa concedida para realização do Doutorado Sanduiche na França (Processo: 232225/2014-1-SWE)

Aos amigos do Laboratório de Ótica e Fotônica da Embrapa Instrumentação: Anielle, Carla, Alfredo, Gustavo, Alex, Cléber, Camila, Aida, Cléver, Kleydson, Manoel, José, Renata, Beatriz entre outros que passaram durante esses anos.

Aos amigos do Laboratório PROTEE da Université de Toulon, Campus La Garde, França: Houssam, Ayoubi, Amandine, Cédric, entre outros; e aos amigos Grasileiros que fiz durante 1 ano do doutorado sanduiche: Bruna, Indira, Luciana, Andarair, Felipe e Rafael.

$\mathcal{A}$ Embrapa Instrumentação pela infraestrutura e pelo excelente ambiente de trabalho proporcionado a todos.

As analistas de laboratório, Alice Raabe, Silviane Zanni Hubinger e a Viviane Soares da Embrapa Instrumentação, por toda paciência em ensinar e ajudar nos experimentos e análíses durante o desenvolvimento desse trabalho. 
$\mathcal{A}$ todos os funcionários da Embrapa Instrumentação pela ajuda prestada.

Ao Instituto de Químíca de São Carlos da Universidade de São Paulo.

$\mathcal{A}$ Univeristé de Toulon, Campus de La Garde, França.

’̀ minha família, em especial aos meus pais amados, Maria e Walter, se há algo que faz diferença na formação da personalidade e na vida de uma pessoa é o amor que ela recebe. Vocês fizeram de mím a pessoa que sou hoje, tenho muito orgutho de ser fitha de vocês, e só tenho motivos para agradecer pelos pais maravilhosos que Deus me concedeu.

Ao meu querído irmão, Waltinho, pelo carinho, amor $e$ companheirísmo em todas as horas, e por sempre se preocupar com a minha saúde física e mental.

Aos meus avós, Lourdes e Olavo, pela grandiosa fé em Deus, sempre pedindo em suas orações que o menino Jesus iluminasse a minha caminhada nos estudos.

As minhas amigas pela amizade: Ana Lúcia, Andarair, Anielle, Bruna, Carla, Flávía, Fernanda, Glaucía, Indira, Líliane, Luciana, Maraine, Natália, Nayrê, Tailine as quais sempre me fizeram esquecer as preocupações do dia-a-dia com nossos bate-papos.

O ser humano nunca consegue aprender tudo, mas é através da aprendizagem e cooperatividade que ele alcança seus objetivos. Quero agradecer, a todos que de alguma forma contribuiram para o desenvolvimento e a concretização desse Doutorado. 
".... Os sonhos não determinam o lugar onde vocês vão chegar, mas produzem força necessaría para tira-los do lugar em que vocês estão. Sonhem com as estrelas para que vocês possam pisar pelo menos na lua. Sonhem com a lua para que vocês possam pisar pelo menos nos altos montes. Sonhem com os altos montes para que vocês possam ter dignidade quando atravessarem os vales das perdas e das frustrações. Bons alunos aprendem a matemática numérica, alunos fascinantes vão além, aprendem a matemática da emoção, que não tem conta exata e que rompe a regra da lógica. Nessa matemática vocêe só aprende a multiplicar quando aprende a dividir, só consegue ganhar quando aprende a perder, só consegue receber, quando aprende a se doar...." (Angusto cury) 
Tadini, A.M. Gêneses de Espodossolos Amazônicos: um estudo sobre estrutura e mobilidade da matéria orgânica. 2017. 168f. Tese (Doutorado em Química Analítica) - Instituto de Química de São Carlos (USP - São Carlos), Université de Toulon (França), São Carlos, 2017.

\section{RESUMO}

Os solos têm um importante papel na maioria das atividades que ocorrem no planeta, dentre as quais, destaca-se a sua participação nos principais ciclos biogeoquímicos. A matéria orgânica do solo (MOS) tem um papel primordial na sustentabilidade ambiental, pois está relacionada com a ciclagem de carbono e nutrientes, sendo assim uma figura chave tanto para estudos relacionados com mudanças climáticas globais, quanto para estudos agronômicos. Um dos principais fluoróforos da MOS são as substâncias húmicas ( $\mathrm{SH}$ ), as quais são fracionadas de acordo com a sua solubilidade em ácidos húmicos $(\mathrm{AH})$, ácidos fúlvicos (FA) e humina (HU). O estudo das propriedades ópticas da matéria orgânica é uma importante ferramenta para a compreensão estrutural e molecular das frações húmicas. Frente ao exposto, esse trabalho teve com objetivo estudar a gêneses de Espodossolos Amazônicos através da avaliação das características estruturais da matéria orgânica e suas propriedades de complexação com metais empregando diversas técnicas espectroscópicas. Os resultados mostraram grandes acúmulos de carbono em profundidade e que a Matéria Orgânica nesses Espodossolos Amazônico é constituída de quatro grupos: - mais recalcitrante, humificada e antiga; - lábil e jovem; - recalcitrante, pouco humificada e antiga; - humificada e jovem. Claramente o trabalho mostrou que o processo de humificação não tem relação direta com a datação do material orgânico, e que fatores como textura, presença de água e microorganismos influenciaram nos processos de formação e humificação desse material orgânico. Por fim, a fração AF do solo parece ter uma contribuição oriunda de lençóis freáticos, sua estrutura química varia pouco no perfil e possui seletividade na interação com os metais presentes nesses solos. Basicamente, o AF tem alta afinidade de complexação com Al. A fração AH, entretanto, mostrou-se menos seletiva, associando-se com vários tipos de metais, como $\mathrm{K}, \mathrm{Fe}, \mathrm{Mg}, \mathrm{Zn}$ e $\mathrm{Al}$; e sua estrutura química varia bastante no perfil do solo. Em função da diversidade de metais associados ao $\mathrm{AH}$, ele deve ser o principal responsável pela fertilidade do solo. Desta forma, os resultados mostraram que as três frações húmicas estão envolvidas no processo de podzolização do solo, e que o AF tem papel predominante no transporte de $\mathrm{Al}$ e o $\mathrm{AH}$ é o responsável no transporte do Fe.

Palavras-chave: Matéria Orgânica, Substâncias Húmicas, Ácidos Húmicos, Ácidos Fúlvicos, Humina, Caracterização, Gêneses, Estrutura, Mobilidade. 
Tadini, A.M. Genèse des Spodosols Amazoniens: une étude sur la structure et la mobilité de la matière organique. 2017. 168f. Thèse (doctorat en chimie analytique) - Instituto de Química de São Carlos (USP - São Carlos), Université de Toulon (França), São Carlos, 2017.

\section{RÉSUMÉ}

Les sols jouent un rôle important dans la plupart des activités qui se produisent sur terre, parmi lesquelles sa participation dans les grands cycles biogéochimiques n'est pas des moindres. En effet, La matière organique des sols (MOS) joue un rôle clé dans la durabilité environnementale, car elle est liée au cycle du carbone et des nutriments et ceci est un élément primordial pour les études liées au changement climatique mondial et pour les études agronomiques. Parmi les principaux constituants de la MOS il y a les substances humiques (SH) qui sont elles mêmes fractionnées en fonction de leur solubilité en acides humiques $(\mathrm{AH})$, acides fulviques (AF) et humine (HU). L'étude des propriétés optiques de la matière organique est un outil important pour la compréhension structurale et moléculaire des fractions humiques. Ce travail porte sur la genèse de Spodosols Amazonien par l'évaluation des caractéristiques structurelles de leur matière organique et leur propriétés de complexation métallique en utilisant diverses techniques spectroscopiques. Les résultats ont montré de grandes accumulations de carbone en profondeur et que la matière organique dans ces Spodosols Amazoniens est constituée de quatre groupes: - plus récalcitrant, humifié et ancien; - labile et jeune; - récalcitrant, peu humifié et ancien; - humifié et jeune. De toute évidence, le travail a montré que le processus d'humification n'a aucune relation directe avec la datation de la matière organique et que des facteurs tels que la texture, la présence d'eau et les microorganismes ont influencé les processus de formation et d'humification de cette matière organique. Enfin, la fraction des AF du sol semble avoir une contribution provenant des eaux souterraines, sa structure chimique variant peu au sein d'un profil et ayant une interaction sélective avec les métaux présents dans ces sols. La fraction des $\mathrm{AH}$, cependant, s'est révélée moins sélective, associé divers types de métaux, tels que $\mathrm{K}, \mathrm{Fe}, \mathrm{Mg}, \mathrm{Zn}$ et Al. Par contre, la structure chimique des $\mathrm{AH}$ semble dépendre du profil de sol. En raison de la diversité des métaux que les $\mathrm{AH}$ peuvent complexer, ils pouvraient être les principaux responsables de la fertilité du sol. Les résultats ont montré que les trois fractions humiques ( $\mathrm{AF}, \mathrm{AH}$ et $\mathrm{HU}$ ) sont fortement impliquées dans le processus de podzolisation des sols et que les AF ont un rôle prédominant dans le transport d'Al tandis que les $\mathrm{AH}$ sont les responsable du transport du Fe.

Mots-clés: Matière Organique; Substances Humiques; Acides Humiques; Acides Fulviques; Humine; Caractérisation; Genèse; Structure; Mobilité. 
Tadini, A.M. Genesis of Amazonian Spodosols: a study on the structure and mobility of organic matter. 2017. 168f. Thesis (PhD in Analytical Chemistry) - Instituto de Química de São Carlos (USP - São Carlos), Université de Toulon (França), São Carlos, 2017.

\begin{abstract}
Soils play an important role in most of the activities that occur on the planet. It participation in the main biogeochemical cycles can be highlighted. Soil organic matter (SOM) plays a key role in environmental sustainability, since it is related to carbon and nutrient cycling, being essential for studies related to global climate change and agronomy. One of the major SOM fluorophore is the humic substances (HS), which is fractionated according to their solubility in humic acids (HA), fulvic acids (FA) and humin (HU). The study of the optical properties of the organic matter is an important tool for structural and molecular understanding of humic fractions. Based on that, this work aimed the study of the Amazonian Spodosols genesis through the evaluation of organic matter structural characteristics and its properties of metal complexation using different spectroscopic techniques. The main results of this research showed large carbon accumulations in depth. Furthermore, it was possible to infer how the Amazonian Spodosols organic matter is divided: - more recalcitrant, humified and old; - labile and young; - recalcitrant, little humified and old; - humified and young. The study demonstrated clearly that the humification process has no direct relationship with the organic material dating, and that factors such as texture, presence of water and microorganisms have influenced the formation and humification of that organic material. The FA fraction of the soil has a contribution from groundwater and its chemical structure varies little in depth. Additionally, FA showed selective interaction with soil metals. However, the HA fraction has been shown less selective, associate with various metal types, such as $\mathrm{K}, \mathrm{Fe}, \mathrm{Mg}, \mathrm{Zn}$ and $\mathrm{Al}$. Moreover, its chemical structure varies greatly in the soil depth. Due to the diversity of metals that the HA has affinity, it should be the main responsible of the soil fertility. After all, the results showed that all the three humic fractions are involved in the process of soil podzolization. Furthermore, the FA has a predominant role in $\mathrm{Al}$ transport as the $\mathrm{HA}$ is the responsable of $\mathrm{Fe}$ transport.
\end{abstract}

Keywords: Organic Matter; Humic Substances; Humic Acids; Fulvic Acids; Humin; Characterization; Genesis; Structure; Mobility. 


\section{Lista de Figuras}

Figura 2.1: Esquema de formação do solo do tipo Espodossolo que ocorre na região Amazônica.

Figura 2.2: Esquema da dinâmica da matéria orgânica no solo apresentando seus processos e

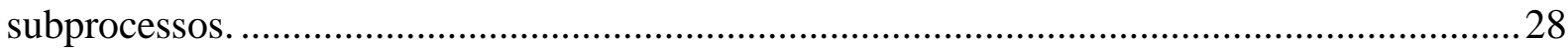

Figura 2.3: Mecanismo de formação das Substâncias Húmicas............................................... 30

Figura 2.4: Modelo do Ácido Húmico proposto por Schulten e Schnitzer (1993)................... 32

Figura 2.5: Modelo Macromolecular do Ácido Húmico proposto por Schulten e Schnitzer (1997).

Figura 2.6: Modelo Supramolecular do Ácido Húmico proposto por Piccolo (2001)............. 34

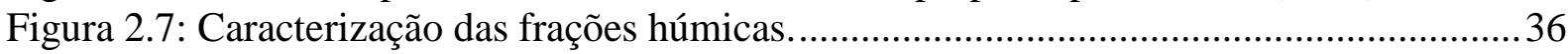

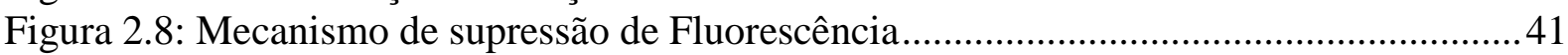

Figura 4.9: Localização da área de estudo na região Amazônica.............................................50

Figura 4.10: Representação da área de estudo e dos perfis de solos na transecção. Vale ressaltar que o Solo P3 como mostra o mapa da localização da área (Figura 4.9) está deslocado, por isso não se encontra no perfil.

Figura 5.I.11: Espectro de Emissão em $405 \mathrm{~nm}$ obtido pelo LIFS para os vários horizontes das amostras dos Espodossolos: P1 (a), P2 (b), P3 (c) e P4 (d). Observação nos P1, P2 e P3 a maioria dos seus horizontes estão em condições hidromórfica, ou seja, sob influência do

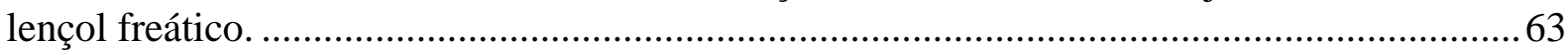
Figura 5.I.12: Valores de $\mathrm{H}_{\text {LIFS_M }}$ dos solos em função da datação de carbono dos Espodossolos P1, P3 e P4.

Figura 5.II.13: Espectro típico de Infravermelho de Ácido Húmico extraído do Espodossolo Hidromórfico (P1).

Figura 5.II.14: Espectro típico de Infravermelho de Ácido Fúlvico extraído do Espodossolo Hidromórfico (P1). 80

Figura 5.II.15: Espectro típico de Infravermelho de Humina extraído do Espodossolo

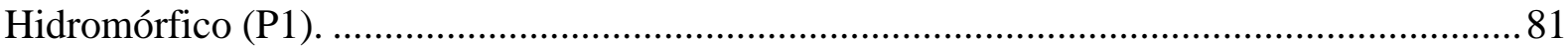
Figura 5.II.16: Espectro típico de Infravermelho das amostras (a) Ácido Húmico, (b) Ácido Fúlvico e (c) Humina extraídos do Espodossolo Hidromórfico (P2)

Figura 5.II.17: Espectro típico de Infravermelho das amostras (a) Ácido Húmico, (b) Ácido Fúlvico e (c) Humina extraídos do Espodossolo Hidromórfico (P3) .................................... 157 Figura 5.II.18: Espectro típico de Infravermelho das amostras (a) Ácido Húmico, (b) Ácido Fúlvico e (c) Humina extraídos do Espodossolo Bem Drenado (P4)...

Figura 5.II.19: Picos da intensidade da banda das amostras de: (a) ácido húmico, (b) ácido fúlvico e (c) humina extraídos do Espodossolo Hidromórfico (P1). 83 Figura 5.II.20: Picos da intensidade da banda das amostras de: (a) ácido húmico, (b) ácido fúlvico e (c) humina extraídos do Espodossolo Hidromórfico (P2) ...................................... 85 Figura 5.II.21: Picos da intensidade da banda das amostras de: (a) ácido húmico, (b) ácido fúlvico e (c) humina extraídos do Espodossolo Hidromórfico (P3) ........................................8. 87 Figura 5.II.22: Picos da intensidade da banda das amostras de: (a) ácido húmico, (b) ácido fúlvico e (c) humina extraídos do Espodossolo Bem Drenado (P4).

Figura 5.II.23: Espectros de Fluorescência bidimensional utilizando a metodologia proposta por Kalbitz et al. (1999) para as amostras de (a) ácido húmico e (b) ácido fúlvico do Espodossolo Hidromórfico (P1). 158

Figura 5.II.24: Espectros de Fluorescência bidimensional utilizando a metodologia proposta por Kalbitz et al. (1999) para as amostras de (a) ácido húmico e (b) ácido fúlvico do Espodossolo Hidromórfico (P2)................................................................................... 158 Figura 5.II.25: Espectros de Fluorescência bidimensional utilizando a metodologia proposta 
por Kalbitz et al. (1999) para as amostras de (a) ácido húmico e (b) ácido fúlvico do Espodossolo Hidromórfico (P3).

Figura 5.II.26: Espectros de Fluorescência bidimensional utilizando a metodologia proposta por Kalbitz et al. (1999) para as amostras de (a) ácido húmico e (b) ácido fúlvico do Espodossolo Bem Drenado (P4).

Figura 5.II.27: Espectros de Fluorescência bidimensional utilizando a metodologia proposta por Milori et al. (2002) para as amostras de (a) ácido húmico e (b) ácido fúlvico do Espodossolo Hidromórfico (P1). 160

Figura 5.II.28: Espectros de Fluorescência bidimensional utilizando a metodologia proposta por Milori et al. (2002) para as amostras de (a) ácido húmico e (b) ácido fúlvico do Espodossolo Hidromórfico (P2). 160 Figura 5.II.29: Espectros de Fluorescência bidimensional utilizando a metodologia proposta por Milori et al. (2002) para as amostras de (a) ácido húmico e (b) ácido fúlvico do Espodossolo Hidromórfico (P3).

Figura 5.II.30: Espectros de Fluorescência bidimensional utilizando a metodologia proposta por Milori et al. (2002) para as amostras de (a) ácido húmico e (b) ácido fúlvico do Espodossolo Bem Drenado (P4).

Figura 5.II.31: Gráfico de correlação dos índices de humificação das amostras de (a) ácido húmico e (b) ácido fúlvico empregando as metodologias Milori et al., 2002 ( $\mathrm{A}_{465 \mathrm{~nm}}$ ) e Kalbitz et al., $1999\left(\mathrm{I}_{450 \mathrm{~nm}} / \mathrm{I}_{370 \mathrm{~nm}}\right)$.

Figura 5.II..32: Valores de $\mathrm{A}_{465 \mathrm{~nm}}$ dos ácidos húmicos em função da datação de carbono dos Espodossolos P1, P3 e P4.

Figura 5.II.33: Espectro de Emissão de Fluorescência de uma solução de $3 \mathrm{mg} \mathrm{L}^{-1}$ de lignina e ácido húmico de 12,5 $\mathrm{mg} \mathrm{L}^{-1}$ (amostra utilizada foi: P1 Bh-C 240).

Figura 5.II.34: Espectros na modalidade emissão-excitação das amostras de ácido húmico do Espodossolo Hidromórfico (P1) para as diferentes profundidades: (a) P1 A 0-15, (b) P1 A-E 15-30, (c) P1 Bh 40-50, (d) P1 Bh-C 240, (e) P1 Bh-C 260 e (f) P1 C 350.

Figura 5.II.35: Espectros na modalidade emissão-excitação das amostras de ácido fúlvico do Espodossolo Hidromórfico (P1) de diferentes profundidades: (a) P1 A 0-15, (b) P1 A-E 1530, (c) P1 Bh 40-50, (d) P1 Bh-C 240, (e) P1 Bh-C 260 e (f) P1 C 350.

Figura 5.II.36: Espectros na modalidade emissão-excitação das amostras de humina do Espodossolo Hidromórfico (P1) de diferentes profundidades: (a) P1 A 0-15, (b) P1 A-E 1530, (c) P1 Bh 40-50, (d) P1 Bh-C 240, (e) P1 Bh-C 260 e (f) P1 C 350................................ 98 Figura 5.II.37: Espectros na modalidade emissão-excitação para as amostras de ácido húmico do Espodossolos Hidromórfico (P2) para as diferentes profundidades: (a) P2 A 0-15, (b) P2 A-E $15-30$ e (c) P2 Bh 290.

Figura 5.II.38: Espectros na modalidade emissão-excitação para as amostras de ácido fúlvico do Espodossolos Hidromórfico (P2) para as diferentes profundidades: (a) P2 A 0-15, (b) P2 A-E $15-30$ e (c) P2 Bh 290.

Figura 5.II.39: Espectros na modalidade emissão-excitação para as amostras de Humina do Espodossolos Hidromórfico (P2) para as diferentes profundidades: (a) P2 A 0-15, (b) P2 A-E 15-30 e (c) P2 Bh 290

Figura 5.II.40: Espectros na modalidade emissão-excitação para as amostras de Ácido Húmico do Espodossolos Hidromórfico (P3) para as diferentes profundidades: (a) P3 A 0-15, (b) P3 Bh 165-175, (c) P3 Bh 180-183, (d) P3 Bh 210, (e) P3 Bh 280-310 e (f) P3 Bh 335350 .

Figura 5.II.41: Espectros na modalidade emissão-excitação para as amostras de Ácido Fúlvico do Espodossolos Hidromórfico (P3) para as diferentes profundidades: (a) P3 A 0-15, (b) P3 Bh 165-175, (c) P3 Bh 180-183, (d) P3 Bh 210, (e) P3 Bh 280-310 e (f) P3 Bh 335350 . 
Figura 5.II.42: Espectros na modalidade emissão-excitação para as amostras de Humina do Espodossolos Hidromórfico (P3) para as diferentes profundidades: (a) P3 A 0-15, (b) P3 Bh 165-175, (c) P3 Bh 180-183, (d) P3 Bh 210, (e) P3 Bh 280-310 e (f) P3 Bh 335-350.......... 164 Figura 5.II.43: Espectros na modalidade emissão-excitação para as amostras de Ácido Húmcio do Espodossolos Bem Drenado (P4) para as diferentes profundidades: (a) P4 A 0-20, (b) P4 A 20-30, (c) P4 A 30-40, (d) P4 Bh 110-120, (e) P4 Bh 170-180, (f) P4 Bh-C 270-280,

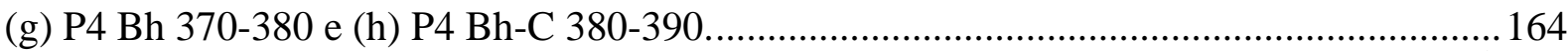
Figura 5.II.44: Espectros na modalidade emissão-excitação para as amostras de Ácido Fúlvico do Espodossolos Bem Drenado (P4) para as diferentes profundidades: (a) P4 A 0-20, (b) P4 A 20-30, (c) P4 A 30-40, (d) P4 Bh 110-120, (e) P4 Bh 170-180, (f) P4 Bh-C 270-280, (g) P4 Bh 370-380 e (h) P4 Bh-C 380-390. 165 Figura 5.II.45: Espectros na modalidade emissão-excitação para as amostras de Humina do Espodossolos Bem Drenado (P4) para as diferentes profundidades: (a) P4 A 0-20, (b) P4 A 20-30, (c) P4 A 30-40, (d) P4 Bh 110-120, (e) P4 Bh 170-180, (f) P4 Bh-C 270-280, (g) P4 Bh 370-380 e (h) P4 Bh-C 380-390.

Figura 5.II.46: Representação dos Componentes obtidos pelo PARAFAC: CI (a) e CII (b) presentes nos extratos de ácidos húmicos extraídos dos quatros Espodossolos Amazônico. ..99 Figura 5.II.47: Razão ComponenteII/ComponenteI das amostras de ácido húmico dos quatros Espodossolos Amazônico com o decorrer da profundidade................................................ 101 Figura 5.II.48: Representação dos Componentes: CI (a) e CII (b) presentes nos extratos de ácido fúlvico extraídos dos quatros Espodossolos Amazônico............................................. 101 Figura 5.II.49: Razão ComponenteII/ComponenteI das amostras de ácido fúlvico dos quatros Espodossolos Amazônico com o decorrer da profundidade............................................... 102 Figura 5.II.50: Representação dos Componentes: CI (a) e CII (b) presentes nos extratos de humina extraídos dos quatros Espodossolos Amazônico. 103 Figura 5.II.51: Razão Componente II /Componente I das amostras de humina dos quatros Espodossolos Amazônico com o decorrer da profundidade............................................... 104

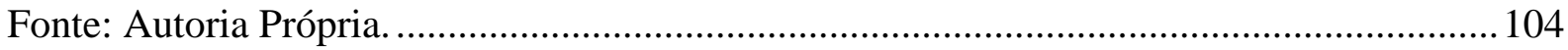
Figura 5.II.52: Espectro típico obtido pelo LIBS com duplo pulso para amostra do Espodossolo hidromórfico (P1 A 0-15): (a) solo inteiro, (b) ácido húmico, (c) ácido fúlvico e

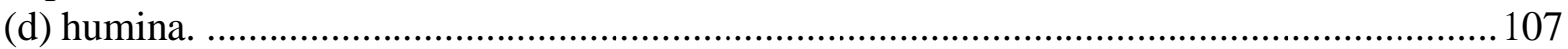
Figura 5.II.53: Representação espectral do LIBS com duplo pulso para amostra do Espodossolo hidromórfico (P1 A 0-15) das linhas: (a) $238 \mathrm{~nm}$ (Ferro), (b) $279 \mathrm{~nm}$ (Magnésio), (c) 285 nm (Manganês) e (d) 309 nm (Alumínio)................................................ 108 Figura 5.II.54: Análise de Componente Principal para as amostras de Ácido Húmico, Ácido Fúlvico e Humina extraídos dos Espodossolo hidromórfico (P1) e Espodossolo bem drenado (P4) em relação aos metais: (a) Ferro (linha $238 \mathrm{~nm}$ ); (b) Magnésio (linha $279 \mathrm{~nm}$ ); (c) Manganês (linha $285 \mathrm{~nm}$ ) e (d) Alumínio (linha $309 \mathrm{~nm}$ ). ............................................... 109 Figura 5.II.55: Curva típica obtida no tratamento do espectro de fluorescência resolvida no tempo do equipamento Quantaurus - Tau J para amostras dos ácidos húmicos do

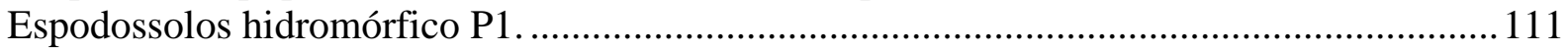
Figura 5.II.56: Gráfico Tempo de vida (T1 e T2) para os (a) ácidos húmico e (b) ácidos fúlvicos extraídos dos Espodossolos Amazônico................................................................. 112 Figura 5.II.57: Espectro obtido pelo RMN das amostras de Ácido Húmico extraídos do Espodossolo Hidromórfico P1 (P1 A 0-15)...............................................................114

Figura 5.II.58: Análise de Componentes Principais (ACP) dos ácidos húmicos e fúlvicos pelos

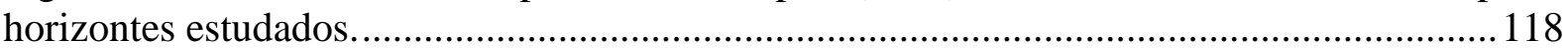
Figura 5.II.59: Análise de Componentes Principais (ACP) dos ácidos húmicos e fúlvicos pelos

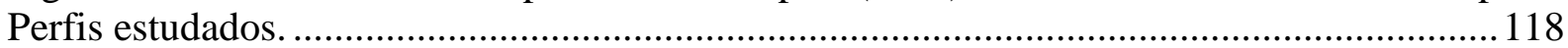
Figura 5.III.60: Espectro de fluorescência na modalidade matriz emissão-excitação (MEE) 
para a amostra de ácido húmico extraído do P1 A 0-15, em que: (a) ácido húmico sem adição de $\mathrm{Cu}$ (II); (b) ácido húmico com adição de $0,26 \mathrm{mg} \mathrm{L}^{-1}$ de $\mathrm{Cu}$ (II); e (c) ácido húmico com adição de 105,59 $\mathrm{mg} \mathrm{L}^{-1}$ de $\mathrm{Cu}$ (II). ........................................................................ 124 Figura 5.III.61: Comparações dos BIAS dos modelos: (a) 1:1 e (b) 1:2 com o metal Cobre (II). 126

Figura 5.III.62: Avaliação da Constante de Estabilidade do $\mathrm{Cu}$ (II) com os ácidos húmico e ácidos fúlvico para o modelo 1:1 127 Figura 5.III.63: Comparações dos BIAS dos modelos: (a) 1:1 e (b) 1:2 com o metal Al (III). 128

Figura 5.III.64: Avaliação da constante de estabilidade do Al (III) com os ácidos húmico e ácidos fúlvico para o modelo 1:1

Figura 5.III.65: Comparação entre as CL (CL1+CL2) dos ácidos húmicos vs dos ácidos fúlvicos para os íons Cu (II) (destacado em vermelho) e os íons Al (III) (destacado em azul) com os BIAS nas barras de erros de cada horizonte.....

Figura 5.III.66: Correlação entre a Capacidade de Complexação (CL1+CL2) dos íons Al (III) vs Cu (II) para os Espodossolos Amazônico. Figura 5.III.67: Análise de Componentes Principais (ACP) dos resultados da análise de quenching das amostras de ácidos húmicos e fúlvicos representado por perfis. 132 Figura 5.III.68: Análise de Componentes Principais (ACP) dos resultados da análise de quenching das amostras de ácidos húmicos e fúlvicos representado por parâmetros e perfis. 


\section{Lista de Tabelas}

Tabela 2.1: Descrição dos horizontes descritos nesse estudo (Embrapa, 2006). 25

Tabela 2.2: Principais bandas obtidas para as frações húmicas empregando o Infravermelho.

Tabela 2.3: Composição mineralogica (Pereira et al., 2013) dos vários horizontes das amostras de Espodossolos: Perfil 1, 2, 3 e 4. Os horizontes destacados, A, A-E, Bh, Bh-C e C, são horizontes que estão sob influência do lençol freático suspenso.

Tabela 4.4: Esquema do procedimento de preparação das amostras para análise de quenching.

Tabela 5.I.5: Valores de Carbono (\%), Nitrogênio (\%) e Hidrogênio (\%) dos Espodossolos Amazônicos.

Tabela 5.I.6: Datação de carbono, valores de cor da Carta Munsell, $\mathrm{H}_{\text {LIFS }}$ e $\mathrm{H}_{\text {LIFS_M }}$ dos horizontes do solo.

Tabela 5.I.7: Concentrações dos metais Potássio (K), Ferro (Fe), Cálcio (Ca), Magnésio (Mg), Zinco (Zn), Alumínio (Al), Manganês (Mn), Cobre (Cu), Crômio (Cr) e Cobalto (Co) nas amostras dos Espodossolos Amazônico.

Tabela 5.II.8: Valores de Carbono (\%), Nitrogênio (\%) e Hidrogênio (\%) das frações húmicas dos perfis de Espodossolos Amazônicos. Observação: consideraram-se os teores de cinzas nas amostras.

Tabela 5.II.9: Rendimento do Carbono obtido pelo processo de extração dos ácidos húmicos, ácidos fúlvicos e humina dos Espodossolos Amazônico.

Tabela 5.II.10: Valores das razões $\mathrm{C} / \mathrm{N}$ e $\mathrm{C} / \mathrm{H}$ das frações húmicas (ácido húmico, fúlvico e humina) dos solos Amazônicos.

Tabela 5.II.11: Valores obtidos pelo teste de cinza das amostras de ácido húmico, ácido fúlvico e humina extraído dos Espodossolos Amazônico.

Tabela 5.II.12: Representação dos picos de intensidade da banda pelo FTIR das frações húmicas extraídas dos Espodossolos Amazônico.

Tabela 5.II.13: Valores do índice de humificação obtido das amostras de ácido húmico e fúlvico aplicando as metodologias propostas por Kalbitz et al. (1999) e Milori et al. (2002) empregando a fluorescência bidimensional.

Tabela 5.II.14: Concentrações dos metais Potássio (K), Ferro (Fe), Magnésio (Mg), Alumínio (Al) e Zinco (Zn) nas amostras das frações húmicas dos Espodossolos Amazônico. 105

Tabela 5.II.15: Valor relativo (\% da área total) dos grupos espectrais do 13C RMN das amostras de ácido húmico e fúlvico dos Espodossolos Amazônico.

Tabela 5.II.16: Porcentagem de alifaticidade e aromaticidade das amostras de ácido húmico e ácido fúlvico dos Espodossolos Amazônico. 
Tabela 5.III.17: Componentes obtidas pelo CP/PARAFAC para as amostras de Ácido Húmico (A e B) e Fúlvico (C, D, E e F) extraídos dos Espodossolos Amazônico com os íons Cu (II) e $\mathrm{Al}$ (III). 124

Tabela 5.III.18: Componentes obtidas pelo CP/PARAFAC para cada Perfil de Espodossolos Amazônico com os íons $\mathrm{Cu}$ (II) e Al (III). 


\section{SUMÁRIO}

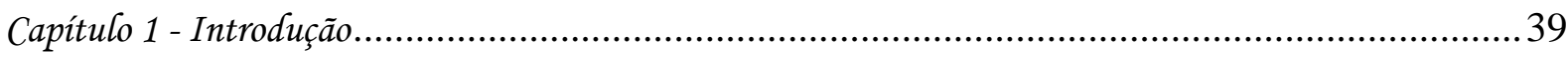

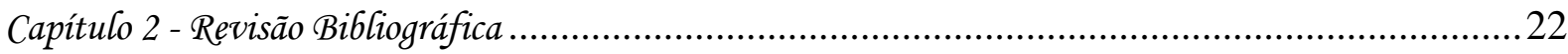

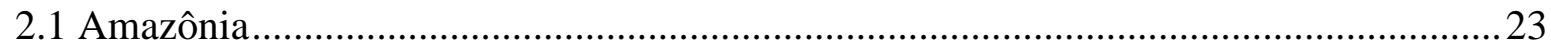

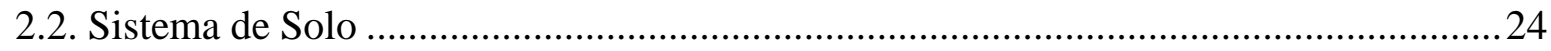

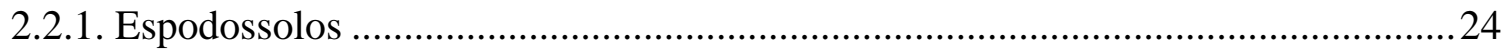

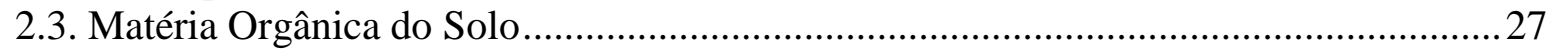

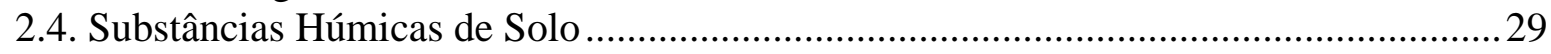

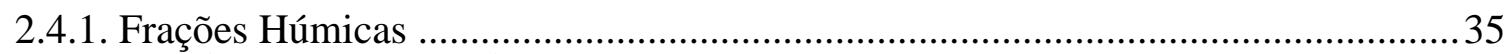

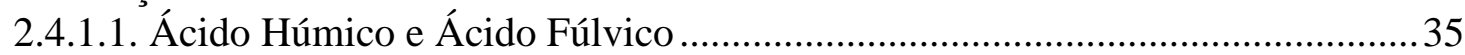

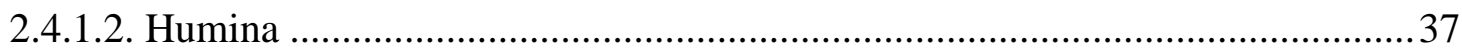

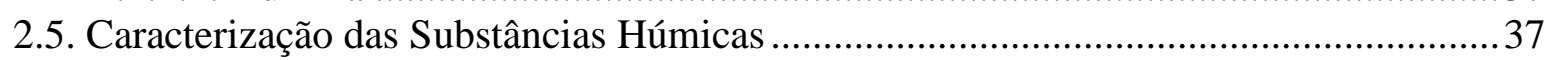

2.5.1. Espectroscopia na região do Infravermelho com Transformada de Fourier ........... 37

2.5.2. Espectroscopia de Fluorescência de luz UV-Vis................................................. 39

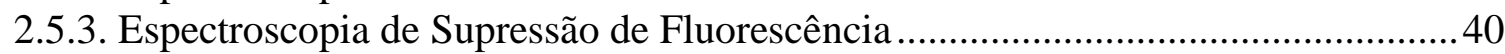

2.5.4. Espectroscopia de Fluorescência Resolvida no Tempo.............................................. 41

2.5.5. Espectroscopia de Fluorescência Induzida a Laser ..................................................42

2.5.6. Espectroscopia de Emissão Ótica com Plasma Induzido por Laser ........................ 43

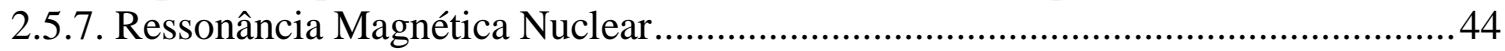

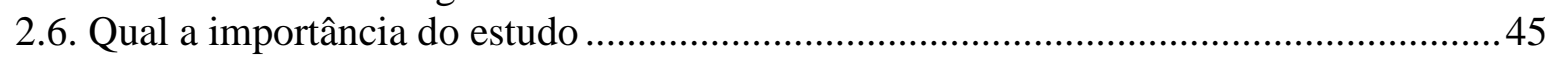

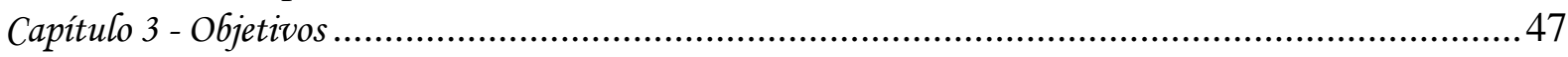

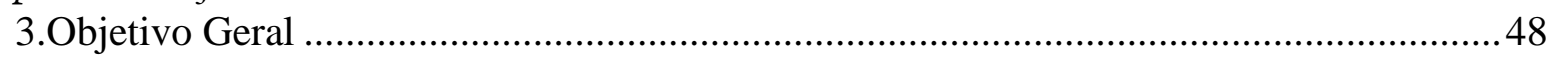

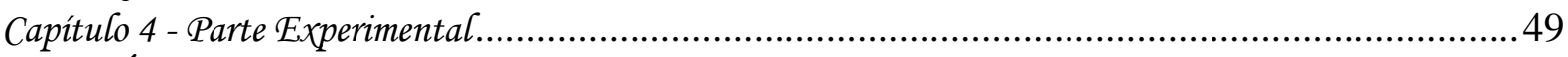

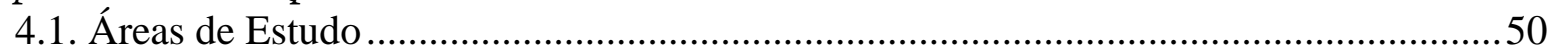

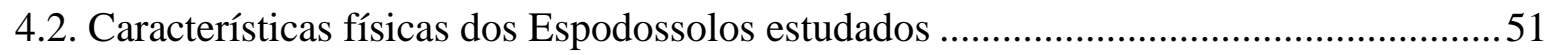

4.3. Amostragem dos solos e Fracionamento Químico das Frações Húmicas .....................53

4.4. Caracterização dos solos e das frações húmicas......................................................54

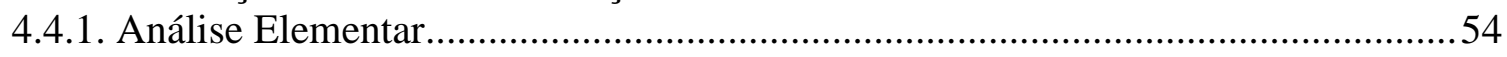

4.4.2. Espectroscopia na região do Infravermelho com Transformada de Fourier ...........54

4.4.3. Espectroscopia de Absorção e de Fluorescência de Luz UV-Visível .....................55

4.4.4 Fluorescência de Supressão (Análise de Quenching) ..............................................55

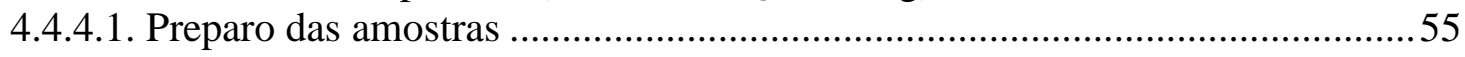

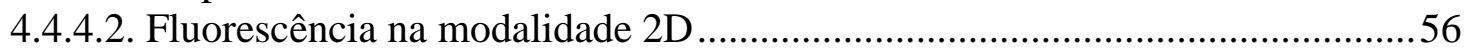

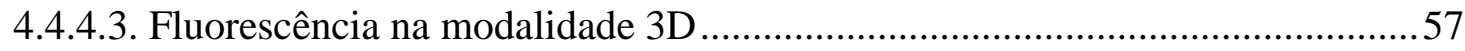

4.4.5. Espectroscopia de Fluorescência Resolvida no Tempo...........................................57

4.4.6. Espectroscopia de Fluorescência Induzida por Laser............................................57

4.4.7. Espectrometria de Absorção Atômica com Atomização por Chama (FAAS) ou

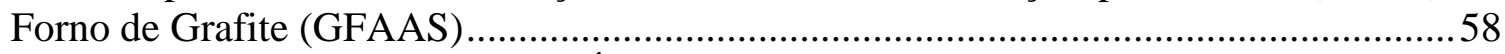

4.4.8. Espectroscopia de Emissão Óptica com Plasma Induzido por Laser ..................... 58

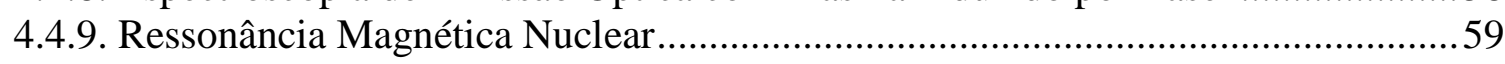

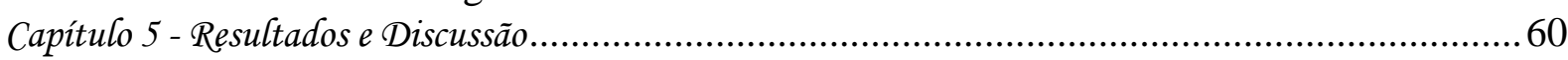

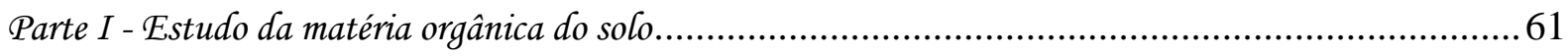

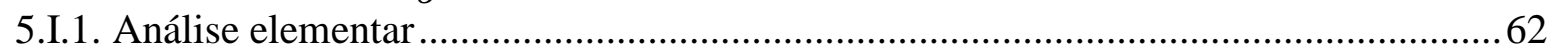

5.I.2. Espectroscopia de Fluorescência Induzida por Laser ..............................................63

5.I.3. Espectrometria de Absorção Atômica com Atomização por Chama ou Forno Grafite

5.I.4. Considerações parciais

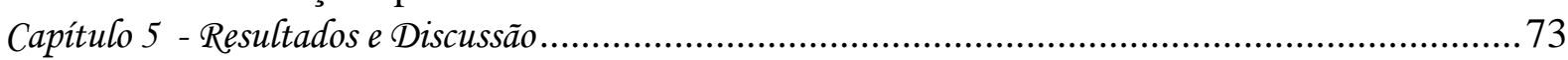




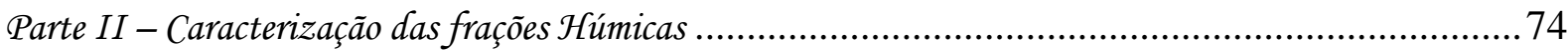

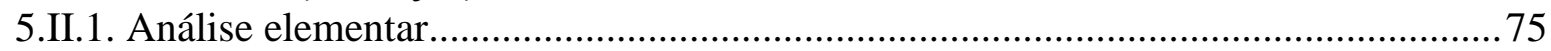

5.II.2. Estudo da Espectrometria de Infravermelho com Transformada de Fourier.............79

5.II.3. Estudo da Espectrometria de Fluorescência .......................................................... 90

5.II.3.1. Determinação dos índices de humificação...................................................... 90

5.II.3.2. Matriz Emissão Excitação (EEM - 3D) ............................................................. 95

5.II.4. Espectrometria de Absorção Atômica com Atomização por Chama ou Forno Grafite

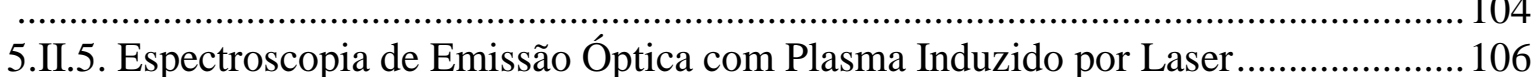

5.II.6. Espectroscopia de Fluorescência Resolvida no Tempo ............................................ 110

5.II.7. Espectroscopia de Ressonânica Magnética Nuclear .............................................. 113

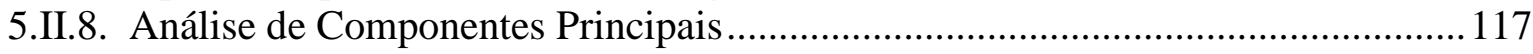

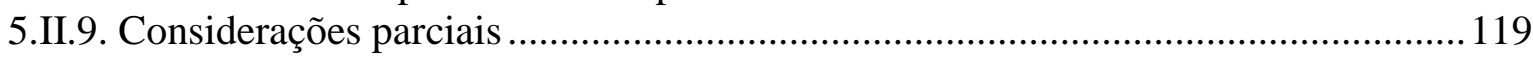

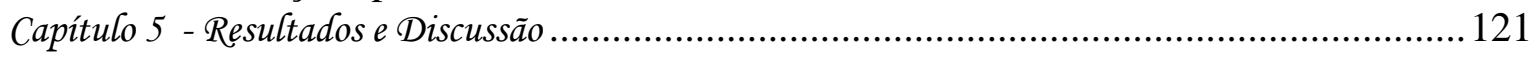

Parte III - Estudo da interação dos Ácidos Húmicos e Ácidos Fúlvicos com os metais .......................... 122

5.III.1. Interações dos Ácidos Húmicos e Ácidos Fúlvicos com os metais Cobre (II) e Al

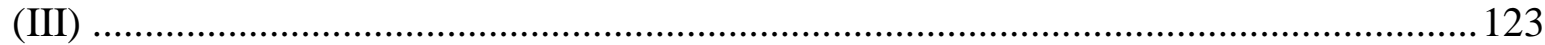

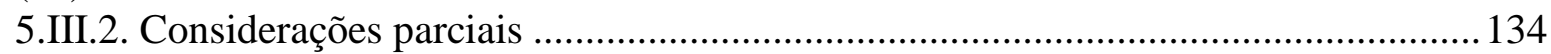

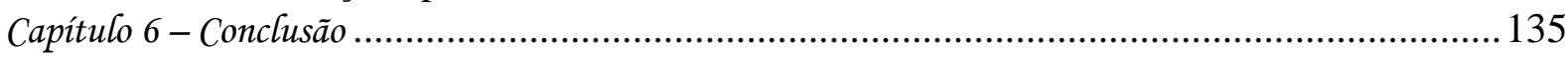

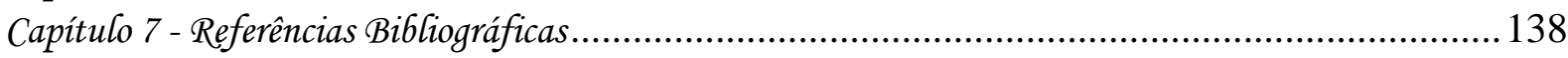

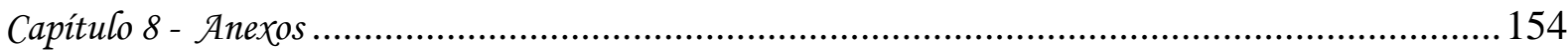

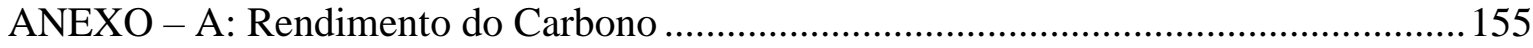

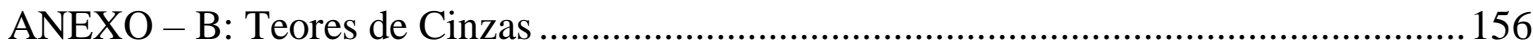

ANEXO - C: Espectros de Infravermelho com Transformada de Fourier.........................157

ANEXO - D: Espectros de fluorescência bidimensional empregando a Espectroscopia de

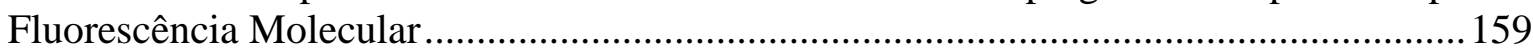
ANEXO - E: Espectros de Fluorescência Tridimensional empregando a Espectroscopia de

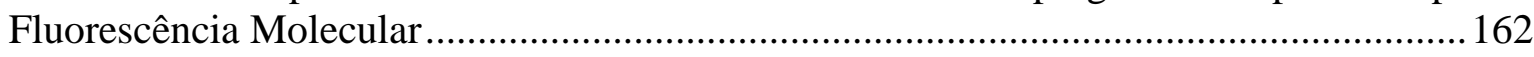

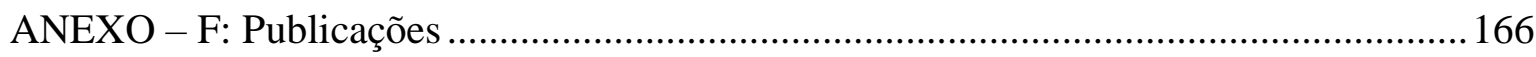


Capítulo 1 - Introdução 
A Floresta Amazônica fornece importantes serviços para a humanidade, tais como: alta biodiversidade, regulação do clima, atua no sequestro de carbono, na regulação dos recursos hídricos e nos ciclos de nutrientes. Os solos tem um importante papel na maioria das atividades que ocorrem no planeta, dentre as quais, destaca-se a sua participação nos principais ciclos biogeoquímicos (Trumbore e Camargo, 2009). Estes são formados por processos pedogenéticos que atuam sobre diferentes rochas e/ou sedimentos subjacentes, cujas características podem ser influenciadas pela combinação de alguns fatores de formação do solo, tais como, material de origem, clima, microoganismo e tempo (Fanning e Fanning, 1989). Na Amazônia, os Espodossolos podem se desenvolver com o tempo a partir de solos Argilosos. A Genesis desse solo ocorre com um movimento da matéria orgânica e óxidos de $\mathrm{Fe}$ e $\mathrm{Al}$ (organometálicos) presente nos horizontes A e/ou E, a se translocarem e acumular-se em horizontes mais profundos, originando horizontes ricos em matéria orgânica. Assim, as mudanças climáticas podem afetar diretamente a integridade física desse tipo de solo, causando alterações importantes na estrutura física e química do solo, além de interferir na qualidade e quantidade da matéria orgânica presente nesse ecossistema.

A Matéria Orgânica do Solo (MOS) tem um papel importante na sustentabilidade ambiental, pois está relacionada com a ciclagem de carbono e nutrientes. Um dos principais componentes da MOS são as substâncias húmicas ( $\mathrm{SH})$, e são fracionadas em ácidos húmicos (HA), ácidos fúlvicos (AF) e humina (HU) de acordo com a solubilidade. A quantidade de carbono orgânico armazenado na camada superficial $\left(\begin{array}{l}0 \\ \text { a }\end{array} 1,0 \mathrm{~m}\right)$ em Espodossolos hidromórficos da bacia do alto Rio Negro representa $87 \pm 7 \mathrm{~kg} \mathrm{~m}^{-2}$ de carbono nesses solos, o que corresponde a $14 \pm 1 \mathrm{Pg}$ de Carbono (Cerri et al., 2000;. Montes et al, 2011). MOS não é homogênea, e estudos com o objetivo de avaliar as características estruturais e os processos que ocorrem com essa matéria orgânica são importantes, especialmente neste ecossistema que é considerado um dos reservatórios de carbono mais importante do mundo (Cerri et al., 2000). Assim, compreender o papel, a dinâmica, as interações e os processos que ocorrem na matéria orgânica do solo são fundamentais para avaliação da qualidade e capacidade do solo em resistir às mudanças em suas propriedades físicas e químicas (Stevenson, 1994).

Frente a estas constatações esta tese de doutorado, visou avaliar as características estruturais da Matéria Orgânica e de suas substâncias húmicas (ácido húmico, ácido fúlvico e humina) em perfis de Espodossolo Amazônico, empregando diversas técnicas espectroscópicas, as quais serão discutidas a seguir. 
Capítulo 2 - Revisão Bibliográfica 


\subsection{Amazônia}

O Brasil possui uma expressiva diversidade de ecossistemas florestais, com climas, vegetações e diferentes solos, dentre os quais se destaca a Floresta Amazônica, que ocupa grandes porções dos territórios da Venezuela, Colômbia, Peru, Guiana, Bolívia e Equador, além do Brasil.

A Floresta Amazônica fornece importantes serviços para a humanidade, tais como: alta biodiversidade, regulação do clima, atua no sequestro de carbono, na regulação dos recursos hídricos e nos ciclos de nutrientes (Coe et al., 2013). Considerada a maior floresta tropical do mundo, cerca de 60\% de sua área encontra-se no Brasil. A Floresta Ombrófila é a vegetação predominante na Amazônia, ou seja, são florestas tropicais com temperatura média de $25^{\circ} \mathrm{C}$ e com alta precipitação durante o ano (IBGE, 2012). Essa vegetação corresponde a $41,67 \%$ do bioma nessa região, dos quais $12,47 \%$ foram alterados pela ação do homem. Sendo que desses $12,47 \%, 2,97 \%$ encontram-se em recuperação com o uso de vegetação secundária e 9,50\% empregado para uso agrícola ou pecuário, e a porcentagem da Floresta Amazônica que permanece inalterada em cada estado varia de 23,82\% no Maranhão a 92,84\% no Amazonas (Brasil, 2013).

A vegetação amazônica é bastante diversificada, apresenta características que variam desde savanas, cerrados e florestas, as quais estão associadas ao clima e ao solo para cada região. Mais de $18 \%$ da região Amazônica é coberta por sistema Latossolo-Espodossolo (Brasil, 1978), que são caracterizados pela justaposição de Espodossolo e Latossolo sobre as mesmas unidades de paisagem; os quais correspondem a 75\% dos solos da região Amazônica (Jacomine e Camargo, 1996; Lucas et al., 2012).

O solo é um sistema reativo quimicamente e heterogêneo sendo distribuídos em compartimentos como biótico, líquido, sólido e gasoso. No compartimento biótico, que envolve plantas, micróbios e a fauna do solo; agem as superfícies de sorção e desorção, os processos de produção e decomposição. Na fase sólida refere-se a conteúdo mineral, inorgânicos e orgânicos, responsáveis pela retenção e reatividade química. A fase líquida contém os compostos químicos dissolvidos livres ou complexados, bem como associados às partículas coloidais. A constituição gasosa do solo envolve os gases liberados pela respiração de raízes, microrganismos devido ao resultado de processos bioquímicos. Assim, a ocorrência das reações depende da mobilidade e disponibilidade química que ocorrem no solo, bem como das suas vias de transferência de massa (Wolf, 1994).

O solo é a camada que cobre a superfície terrestre sendo formado basicamente por matéria orgânica e inorgânica através da ação de fatores climáticos, bióticos e abióticos. 
Segundo a ABNT NBR6502 (1995) o solo é definido como material originário da decomposição de rochas devido a fatores físicos ou químicos, o qual pode conter ou não material orgânico. A matéria orgânica do solo (MOS) representa um dos principais reservatórios de carbono na Terra (Bot e Benites, 2005) e tem um papel fundamental no ciclo do carbono (Kheshgi e Jain, 2003). No solo a matéria orgânica é um importante constituinte, sendo que a sua principal via de formação ocorre por meio da decomposição e transformação de biomoléculas alóctone e autóctone de resíduos vegetais e animais presentes no ambiente (Rodríguez; Núñez, 2011; Paul, 2016). Assim, alterações na composição do solo e ciclo da água causada por fontes antropogênicas e/ou naturais podem interferir na quantidade e natureza química (qualidade) da matéria orgânica do solo presente neste ecossistema, consequentemente, influenciando a sua formação e composição.

\subsection{Sistema de Solo}

\subsubsection{Espodossolos}

Os solos são formados por processos pedogenéticos que atuam sobre diferentes rochas e/ou sedimentos subjacentes, cujas características podem ser influenciadas pela combinação de alguns fatores de formação do solo, tais como, material de origem, clima, microoganismo e tempo (Fanning e Fanning, 1989). O solo tem um importante papel na maioria das atividades que ocorrem no planeta, dentre as quais, destaca-se a sua participação nos principais ciclos biogeoquímico da natureza (Trumbore e Camargo, 2009). No solo, o carbono, ocorre na forma elementar, como carvão e grafite; na forma inorgânica como carbonato, hidrogeno carbonato e dióxido de carbono, e na forma orgânica como húmus de origem vegetal e animal (Hesse, 1971).

O principal processo de diferenciação que ocorre na Amazônia é a Podzolização, que vem sendo estudada por diversos autores (Lucas et al. 1988; Lucas et al. 1998; Lundström et al., 2000, Nascimento et al. 2004; Montes et al. 2007; Nascimento et al. 2008; Fritsch et al. 2009; Montes et al. 2011; Lucas et al. 2012; Pereira et al. 2015), em que os Espodossolos se desenvolvem com o tempo a partir de solos argilosos (Pereira et al. 2015).

Os Espodossolos são solos minerais que apresentam um horizonte E fortemente lixiviado acima do horizonte espódico iluvial com acumulo de matéria orgânica (Fanning e Fanning, 1989). A Tabela 2.1 apresenta a descrição de cada horizonte para o solo. 
Tabela 2.1: Descrição dos horizontes descritos nesse estudo (Embrapa, 2006).

\begin{tabular}{|c|c|}
\hline Horizonte & Descrição / Característica \\
\hline A & Horizonte mineral superficial em que há aporte de matéria orgânica e atividade biológica \\
\hline $\mathrm{E}$ & $\begin{array}{l}\text { Horizonte eluvial ou de lixiviação, resultante do processo de perda de argila, compostos } \\
\text { métlicos, tais como ferro e alumínio ou matéria orgânica provindo do horizonte A }\end{array}$ \\
\hline A-E & Horizonte transicional entre o horizonte A e E \\
\hline $\mathrm{Bh}$ & $\begin{array}{l}\text { Horizonte iluvial resultante da lixiviação de produtos provenientes do horizonte E, em que } \\
\text { ocorre acumúlo de argilas, material orgânico e compostos metálicos (ferro e alumínio) }\end{array}$ \\
\hline $\mathrm{Bh}-\mathrm{C}$ & Horizonte transicional entre o horizonte $\mathrm{Bh}$ e $\mathrm{C}$ \\
\hline $\mathrm{C}$ & $\begin{array}{l}\text { Horizonte formado de restos de minerais, pouco afetado pelos processos pedogenéticos e } \\
\text { com características morfológicas da rocha-mãe }\end{array}$ \\
\hline
\end{tabular}

Fonte: Autoria própria.

Segundo Guimarães (2014), os solos que possuem um horizonte Bh (espódico) sofreram um processo de podzolização, devido a circulação da matéria orgânica nesse solo. O processo da Podzolização dos Espodossolos da região de Barcelos na Amazônia ocorre em formação sedimentares pelo empobrecimento de óxidos de Ferro e argila dos solos arenosos devido ao ambiente hidromórfico (Figura 2.1) (Doupoux et al. 2017).

Figura 2.1: Esquema de formação do solo do tipo Espodossolo que ocorre na região Amazônica.

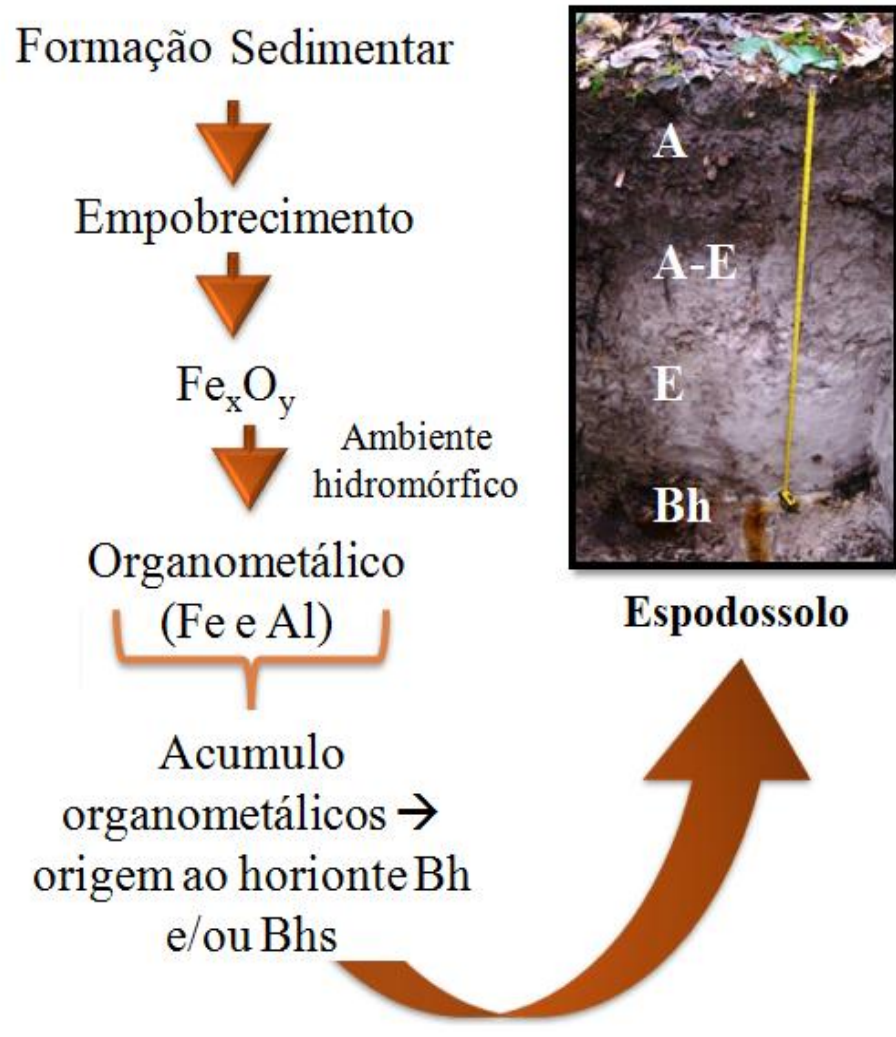

Fonte: Autoria própria.

Os produtos dos minerais aderidos à argila interagem com soluções ricas em compostos orgânicos presentes nesse ambiente saturado por água, que irá favorecer a formação de complexos organometálicos solúveis, principalmente Fe e Al (Bravard e Righi, 1989; 
Oliveira, 2011). Nessa etapa do processo o solo está pobre em argila, o que irá favorecer o movimento da matéria orgânica e de óxidos de $\mathrm{Fe}$ e $\mathrm{Al}$ (organometálicos) presente nos horizontes A e/ou E, a se translocarem e acumular em profundidades que podem variar de $1 \mathrm{a}$ 10 metros, originando horizontes ricos em matéria orgânica, denominados horizontes espódicos (Bh) (Patel-Sorrentino et al. 2007; Resende et al., 2009; Oliveira, 2011; Pereira et al. 2015). Nesses horizontes podem ocorrer o acumulo considerável de carbono em profundidade, tornando-se um reservatório de carbono em escala global (Montes et al. 2011).

Os minerais primários encontram-se nas grandes frações do solo, por exemplo, argila. O ferro ocorre geralmente na forma de óxidos ou complexado à fração orgânica. Assim, o ferro denominado disponível, está predominantemente na forma como óxidos exceto em alguns Espodossolos onde se encontra complexado a matéria orgânica. Esse ferro no solo pode ser reduzido à forma bivalente por agentes oriundos dos produtos da decomposição da matéria orgânica, cujos principais fatores envolvidos na sua mobilização no solo são a formação de complexos ou quelatos. Enquanto que o alumínio no solo pode ocorrer em silicatos de rochas como micas e feldspato, e em argilas. O hidróxido de alumínio, $\mathrm{Al}(\mathrm{OH})_{3}$ ocorre como gibbsita, mas também pode ocorrer como lateritas e óxidos livres associados ao elemento ferro. Sendo que em Espodossolos o alumínio pode ser depositado junto ao ferro como óxidos hidratados ou hidróxidos (Hesse, 1971). Segundo Russel (1961) quando o alumínio passa pelo horizonte $\mathrm{Bh}$, reage com a sílica solúvel, que irá auxiliar na formação da caulinita ou argilas ilíticas (apud Hesse, 1971).

Segundo Patel-Sorrentino e colaboradores (2007), a característica do Espodossolo, é a perda de todos os elementos presentes no horizonte E eluviado, incluindo $\mathrm{Al}$ e Fe, sendo estes poucos solúveis no solo e tornando-se a matéria orgânica o principal componente a ser transportado para os horizontes mais profundos. Na literatura, alguns modelos têm sido propostos para explicar essa interação entre matéria orgânica e os metais, Fe e Al, presente nos Espodossolos, dentre as idelogias, destaca-se a teoria do fulvato. Essa teoria preconiza que os complexos organometálicos solúveis de $\mathrm{Fe}$ e/ou $\mathrm{Al}$ foram formados a partir de compostos de fenólicos de baixo peso molecular, especialmente os ácidos fúlvicos, que podem migrar por meio do lençol freático e ao atingir sua capacidade de complexação precipitam em metais desses compostos orgânicos (Lundstrom, 1993; Patel-Sorrentino et al. 2007). Os quatro solos da região de Barcelos, Amazônia, apresentados nesse trabalho, correspondem a três Espossolos hidromórficos (mal drenados) e um Espodossolo bem drenado. Um Espodossolo bem drenado significa que ele não apresenta nível do lençol freático próximo à superfície, e exibe diferença de coloração bem definidas ao longo do perfil. 
Enquanto que nos Espodossolos mal drenados, também conhecidos como Espodossolo hidromórfico é difícel de verificar uma cor evidente entre seus horizontes. Além disso, a condição úmida proporciona uma grande mobilidade ao ferro, devido às condições redutoras, viabilizando o transporte desse elemento pelo lençol freático até os horizontes superficiais (Nascimento et al., 2004; Fritsch, 2009).

\subsection{Matéria Orgânica do Solo}

Nos compartimentos ambientais aproximadamente $20 \%$ da matéria orgânica natural consiste de compostos orgânicos com estrutura definida, tais como aminoácidos, carboidratos, proteínas e ácidos orgânicos. Os $80 \%$ restantes correspondem a um grupo de estrutura química complexa e indefinida, contendo uma grande variedade de subestruturas alifáticas e aromáticas, ricas em grupos funcionais oxigenados, tais como carbonilas, carboxilas, hidroxilas, fenólicas, sendo denominado de matéria orgânica refratária (Buffle, 1990; Stevenson, 1994). Essa matéria orgânica é resistente à degradação, permanecendo inalterada por longo tempo no ambiente (Buffle, 1990; Rocha e Rosa, 2003; Filella et al. 2005).

A matéria orgânica é um importante componente responsável por vários processos químicos e biológicos que ocorrem no solo, sendo os principais componentes da matéria orgânica as Substâncias Húmicas, as quais correspondem ao redor de $80 \%$ da matéria orgânica dos solos e de 50\% do carbono orgânico em águas superficiais (Rocha e Rosa, 2003; Rocha et al. 2004; Filella et al. 2005; Sloboda et al. 2009).

A matéria orgânica no solo pode atuar na retenção de calor, nos processos de ciclagem de nutrientes, na complexação de substâncias tóxicas (metais e pesticidas), na estruturação e na troca de gases, o que irá aumentar a permeabilidade do solo (Hesse, 1971). Além de atuar como fonte primária de nutrientes para plantas e na susceptibilidade aos processos de erosão no solo (Rocha e Rosa, 2003; Castro, 2008).

Os processos de reatividade química no solo dependem dos processos na fase aquosa, como hidrólise, hidratação, carboxilação e oxi-redução. Os processos bioquímicos, que seriam as sínteses e metabolismos, ocorrem no compartimento biótico e úmido (Wolf, 1994).

A abundância relativa de ácidos orgânicos de baixo peso molecular no solo ocorre seguindo a ordem decrescente: ácidos alifáticos voláteis > ácidos alifáticos não voláteis > ácidos aromáticos. Esses compostos de baixo peso molecular, tais como ácidos: fórmico, acético, lático, cítrico, vanílico, gálico, entre outros, são importantes agentes complexantes afetando a complexação, a disponibilidade e transporte de metais no solo (Wolf, 1994). Enquanto que os aminoácidos são produtos resultantes da atividade microbiana e podem 
ocorrer de forma livre ou complexado ou polimérico no solo. Estes podem reagir no solo por meio de sorção ou polimerização ou por adição nucleofílica de grupos de quinonas de ácidos húmicos, além de estabilizar a complexação com os ácidos húmicos (Stevenson 1982; Wolf, 1994).

A dinâmica da matéria orgânica no solo é controlada por diversos fatores de formação do solo, tais como: tempo, topografia, material de origem, vegetação e clima (Jenny, 1994). Esses fatores possuem estreita relação com a dinâmica, cujos processos (Decomposição, Humificação, Mineralização, Estabilização e Estocagem) e subprocessos (Translocação e Interação) estão exibidos na Figura 2.2.

Primeiramente a matéria orgânica sofre decomposição, na qual moléculas compostas são transformadas em moléculas simples, essas moléculas podem ser mineralizada e/ou ser decomposta por processos de fotossíntese e respiração. Em seguida, esse material sofre o processo de humificação, na qual se tornam moléculas com estrutura complexa com elevado peso molecular (substâncias húmicas), e posteriormente essas moléculas serão estabilizadas e estocadas no solo. Antes de serem estabilizadas, as moléculas de ácidos orgânicos de baixo peso molecular e/ou a matéria orgânica dissolvida pode ser deslocada para profundidades maiores no solo, e por meio da interação com metais e/ou argilas, acumulando-se em horizontes mais profundos (Stevenson, 1986; Zech et al., 1997; Fontana, 2009).

Figura 2.2: Esquema da dinâmica da matéria orgânica no solo apresentando seus processos e subprocessos.

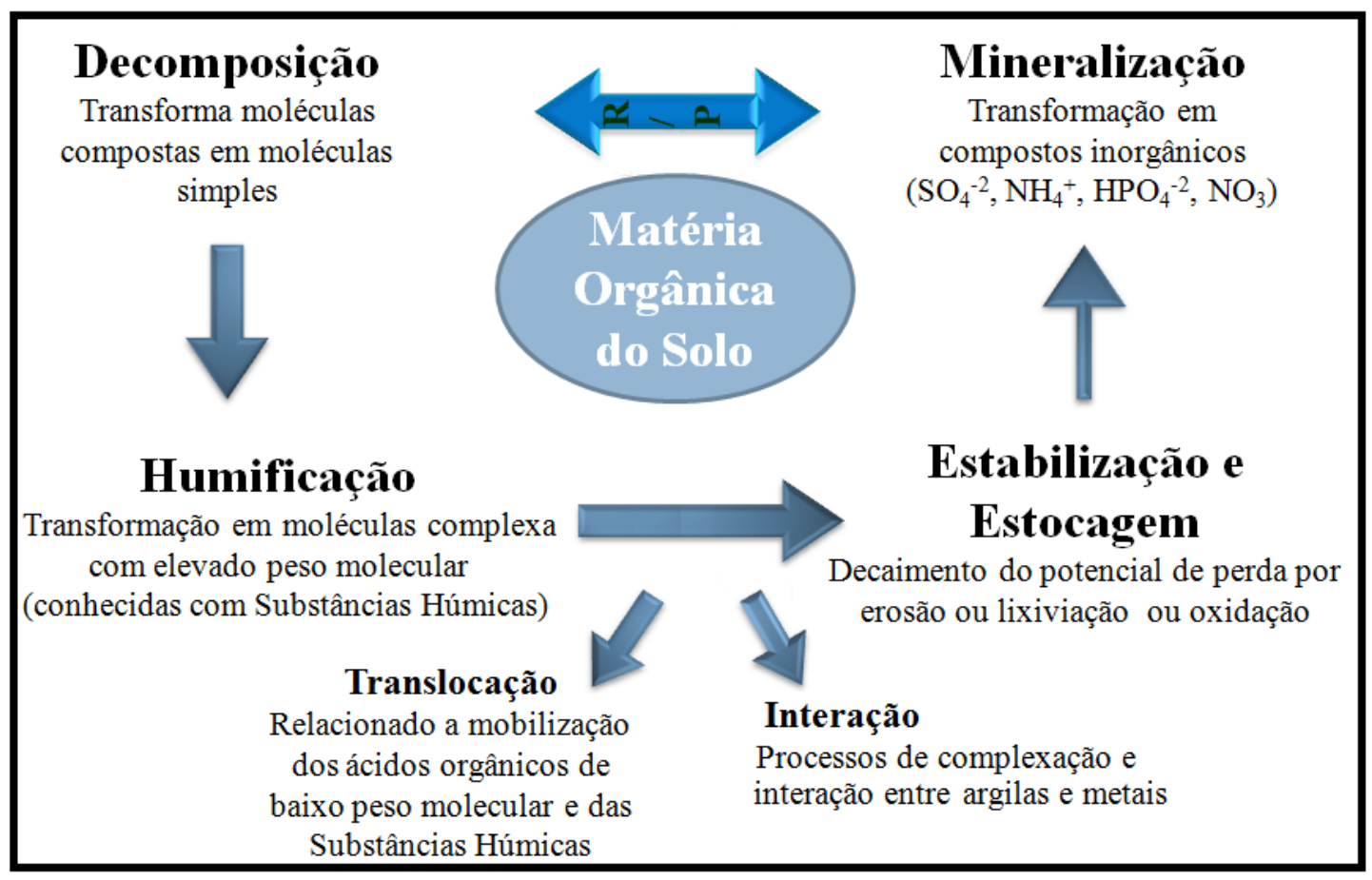

Fonte: adaptado de Fontana 2006, p. 3. 
A MOS não é homogênea, e estudos que visam avaliar as características estruturais e moleculares dessa matéria orgânica são importantes, especialmente na Amazônia, considerado um dos mais importantes reservatórios de carbono do mundo (Cerri et al., 2000). Estudos realizados por Montes e colaboradores (2011) mostroram que nos Espodosssolos o estoque de carbono pode exceder $67 \mathrm{~kg} \mathrm{C} \mathrm{m}^{-2}$ da camada superficial até 5 metros de profundidade, sugerindo que grande parte do carbono orgânico total pode estar sendo armazenado no bioma Amazônico.

De acordo com Paul (2016), a distribuição de composição global da MOS é um armazém de informação valiosa sobre a vegetação, material de origem, clima e perturbação no solo. Esse mesmo autor, diz que a composição química (recalcitrância), a proteção física, as interações química e física (argila, cátions e sesquioxidos) podem ser compreendidas através do conhecimento dos fatores que controlam a formação e dinâmica da matéria orgânica no solo. Assim, qualquer alteração na composição química e física dessa matéria orgânica, não deve ser negligenciada, uma vez que o carbono armazenado nesses solos poderá alterar a concentração de $\mathrm{CO}_{2}$ na atmosfera, sendo um tema importante no cenário atual devido às mudanças climáticas.

\subsection{Substâncias Húmicas de Solo}

As primeiras teorias da formação das substâncias húmicas descrita na literatura relatam que eram produtos de sínteses de compostos biológicos e bem organizados, produzidos durante a decomposição de restos de plantas. Além disso, essas substâncias seriam formadas de tecidos lignificados de resíduos vegetais e/ou de celulose ou ácuçares simples (Stevenson, 1982). Estudos mais recentes abordam que as principais vias de formação das Substâncias Húmicas no solo ocorrem por oxidação dos substratos hidrolisados monoméricos, promovendo a quebra e reações de seus substratos a polímeros macromoleculares de massa molecular elevada (Rocha e Rosa, 2003) e produtos de decomposição da lignina, conforme apresentado na Figura 2.3. 
Figura 2.3: Mecanismo de formação das Substâncias Húmicas.

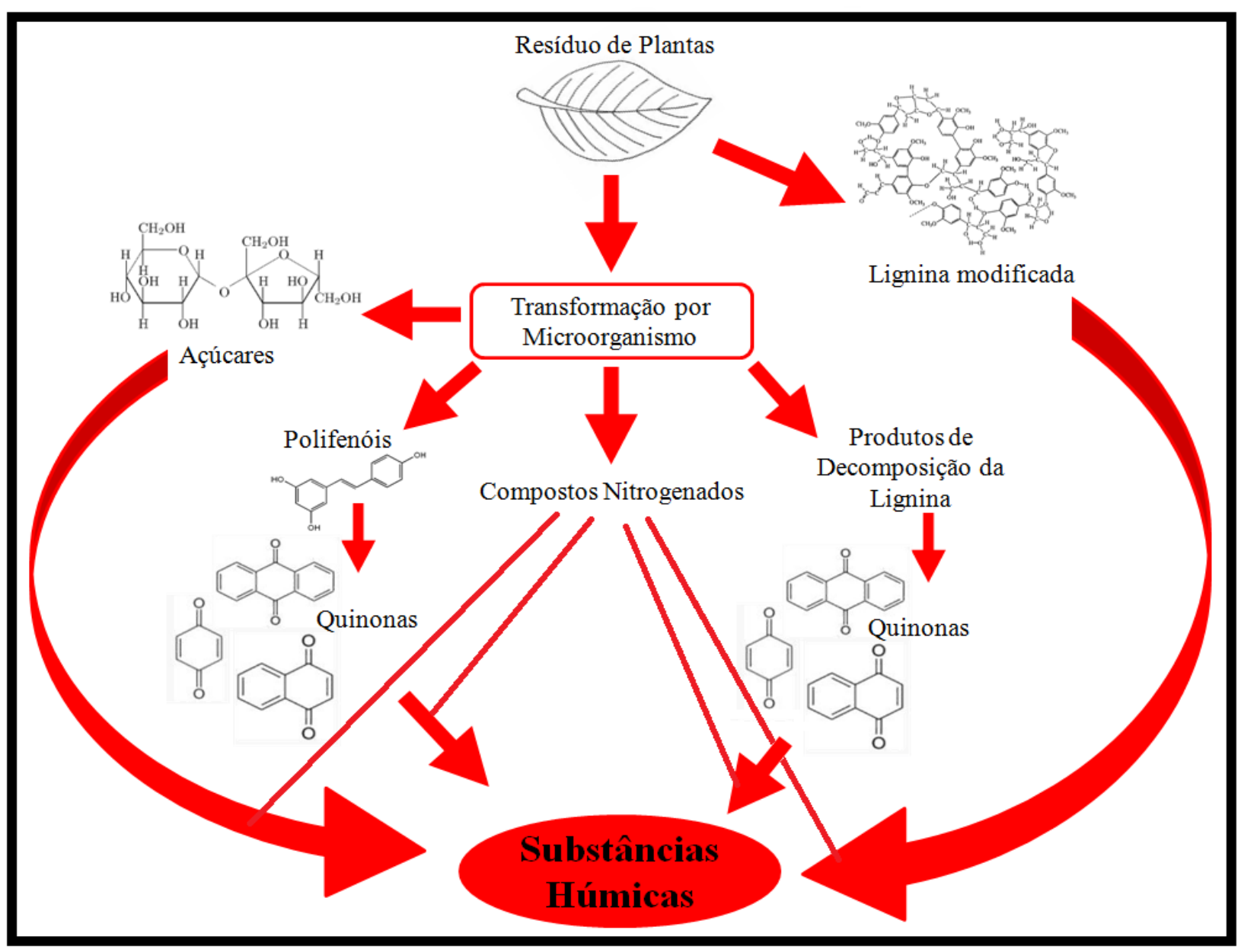

Fonte: adaptado de Rocha e Rosa, 2003, p. 31.

Na literatura é possível encontrar três possíveis fontes de origem do material húmico: (a) derivado de material fenólico de flavonóides de plantas; (b) unidades fenólicas formadas durante a decomposição da lignina e (c) substâncias fenólicas sintetizadas de microorganismos no solo (Burgues et al., 1963; Hatcher et al., 1981). Acredita-se que a lignina e os produtos de sua degradação microbiana nos solos são os progenitores das substâncias húmicas especialmente os ácidos húmicos (Flaig, 1972; Hatcher et al. 1981; Hedges et al. 1984; Piccolo 1996).

As ligninas são polifenóis bioquímicos de plantas vasculares presentes em ambientes terrestres, cuja oxidação desse material vegetal produz uma série de fenóis simples com padrões de substituição característicos (Hedges et al. 1984; Ghaffar et al. 2014; Jex et al. 2014). A quantidade de lignina varia de 15 a $40 \%$ na parede celular das plantas, e tem papel importante no transporte de água, na proteção contra ataque biológico e atua na rigidez e resistência da parede celular (Ghaffar et al. 2014; Jex et al. 2014).

A conversão da lignina às substâncias húmicas pode ocorrer por meio de pequenas 
modificações dos biopolímeros aumentando a sua solubilidade ou pela degradação da lignina em fenóis mais simples e posteriormente ocorrendo a repolimerização de sua estrutura. A presença de fenóis, aldeídos, cetonas e ácidos como produtos de oxidação sugere que esses componentes de lignina existem nas substâncias húmicas como polímeros de fenilpropanóides (presentes em plantas) que estão relativamente intactos e pouco oxidados. As ligninas modificadas podem-se apresentar como principais componentes húmicos em áreas alagadas como turfa, sedimentos e solos alagados, e não em solos bem drenados (Hedges et al. 1984).

A lignina é considerada resistente à degradação microbiana quando comparado a outros compostos como polissacarídeos, aminoácidos presentes nas plantas. Porém, o uso da lignina em estudos que avaliam o ciclo do carbono, tem-se intensificado desde o inicio dos anos 70 . Segundo Jex et al. (2014) a lignina tem um potencial significativo na sua degradação à medida que é percolada no solo. Os principais processos que podem modificar a estrutura química da lignina são: processos físicos (sorção), químicos (fotodegradação) e biológicos (degradação microbiana), cujas condições ambientais são fatores importantes para que ocorram estas modificações (Jex et al. 2014). Compostos orgânicos que persitem no solo como ligninas ou lípidios vegetais podem ser modificados. Além disso, compostos orgânicos mais lábeis como açúcares podem persistir no solo por longos tempos. Esse comportamento pode estar associado à própria natureza do ambiente que pode bloquear a ação ou não de enzimas de degradação por meio da hidrofobicidade, ácidez ou sorção do solo (Schmidt et al. 2011).

Ressalta-se que as SH controlam as principais propriedades físico-químicas de solos (Rocha et al. 2004). Assim, o tipo de uso e ocupação do solo, a sazonalidade, o clima, entre outros fatores, influenciam na formação das SH, não apenas na sua composição, mas também no tipo de processo que a originou, bem como seu grau de humificação (Cheng, 1977; Mcknight et al. 1985; Sargentini Junior et al. 2001; Alberts; Takács, 2004; Filella et al. 2005; Esteves et al. 2009).

As $\mathrm{SH}$ contem grupos funcionais, tais como grupos carboxilas, carbonilas (cetonas e quinonas), hidroxilos (presente em fenóis e em estruturas alifáticas), aminas e amidas (VanLoon et al., 2000). Resíduos de polipeptídios, proteínas, oligossacarídeos e polissacarídeos podem ser encontrados na estrutura das SH, bem como hidratos de carbono, que podem estar aderido por ligações glicosídicas e/ou ligações peptídicas (Hayes, 1985).

As SHs exercem influência diretamente nas propriedades químicas, físicas e biológicas do solo, podendo auxiliar na germinação de sementes devido a sua coloração escura proporcionando à retenção de calor e água; diminuindo a erosão do solo; propiciam uma boa 
capacidade tamponante ao solo; auxiliam na distribuição de macro e micro nutrientes; possuem a capacidade de interagir com espécies metálicas e orgânicas presentes no solo (Rocha e Rosa, 2003; Sutton e Sposito, 2005). No entanto, não há uma estrutura definida para as $\mathrm{SH}$, mas modelos propostos. Assim estudos que viabilizam elucidar e fornecer as características da sua composição molecular e estrutural torna-se de grande valia.

Há algumas propostas de estrutura na literatura para Substâncias Húmicas, sendo uma dessas propostas por Schulten e Schnitzer (1993), que apresentou uma estrutura com composição elementar dos Ácidos Húmicos de $\mathrm{C}_{308} \mathrm{H}_{328} \mathrm{O}_{90} \mathrm{~N}_{5}$, cujo peso molecular foi de 5.540 Da, o qual possuía 66,8\% de Carbono, 6\% de Hidrogênio, 26\% de Enxofre e 1,3\% de Nitrogênio, conforme apresentado na Figura 2.4. Segundo esses autores, o oxigênio presente nos AH proveria dos grupos: carboxílios, fenólicos, hidroxilas presentes em alcoóis, ésteres carboxílicos, éteres e estrutura heterocíclicas com nitrogênio e nitrilos. Os mesmos autores em 1997 propuseram um modelo tridimensional para os AH, o qual apresentavam espaços vazios de diferentes tamanhos moleculares que poderiam alojar compostos orgânicos, como carboidratos, lipídeos, bem como metais (Figura 2.5).

Figura 2.4: Modelo do Ácido Húmico proposto por Schulten e Schnitzer (1993).

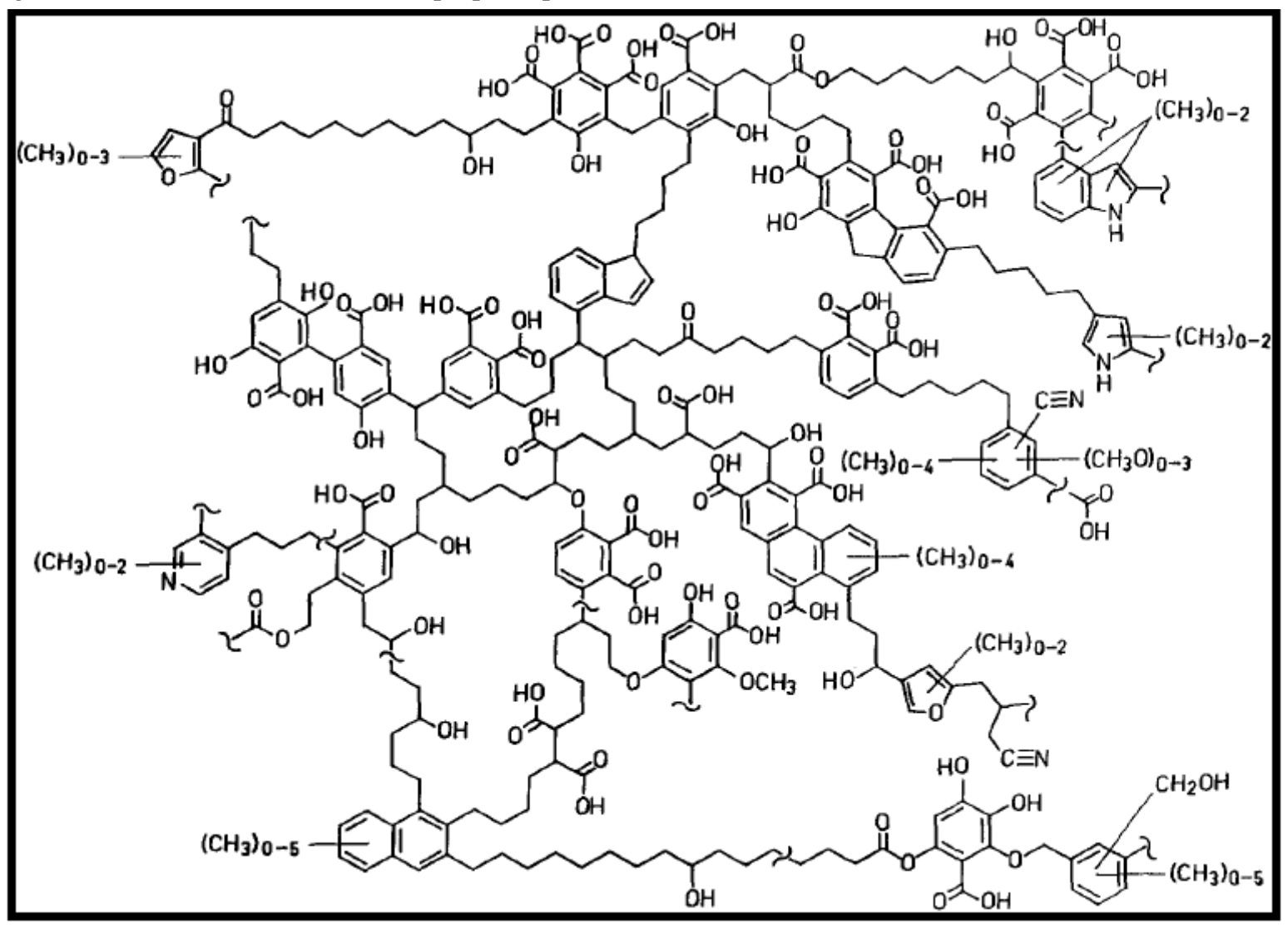

Fonte: adaptado de Schulten e Schnitzer (1993) - número da licença 4244171308544. 
Figura 2.5: Modelo Macromolecular do Ácido Húmico proposto por Schulten e Schnitzer (1997).

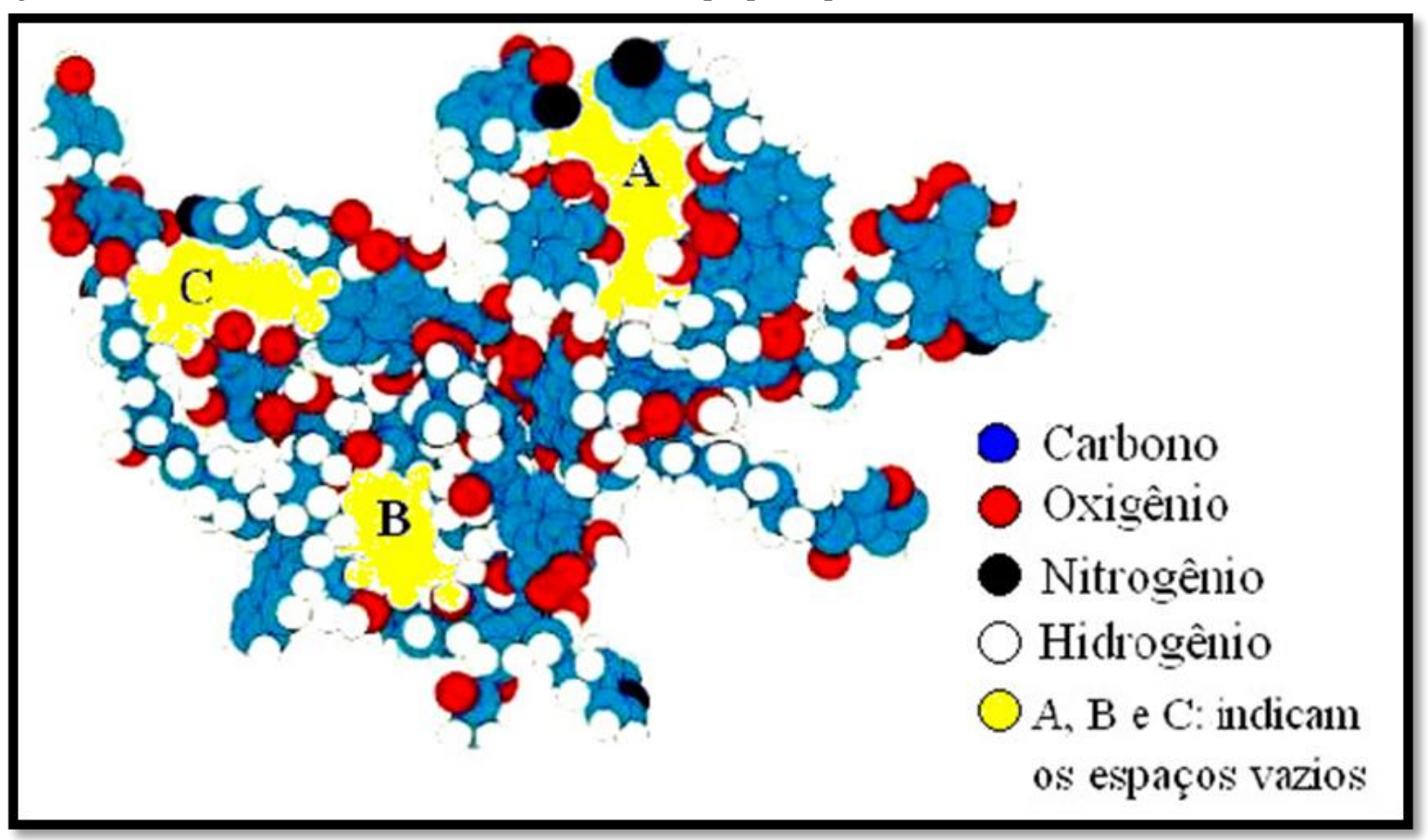

Fonte: adaptado de Schulten e Schnitzer (1997) - número da licença 4244180168726.

A Figura 2.6 apresenta um modelo mais recente, proposto por Piccolo (2001) em que SH seriam formadas por um aglomerado de moléculas heterogêneas de diferentes origens que se auto-organizam em conformações supramoleculares, as quais se unem por interações intermoleculares, tais como ligações de hidrogênio e interações hidrofóbicas. Segundo Piccolo (2016), o novo conceito que descrevem as substâncias húmicas como estrutura supramolecular revogou o conceito de estrutura macromolecular. Assim, as moléculas húmicas do solo são como biomoléculas degradadas de pequenas massas moleculares menores que 5.540 Da, e quando em solução se autorreajustam em supraestruturas metaestáveis e heterogêneas por meio de ligações fracas do tipo Van der Waals $(\pi-\pi$ e CH- $\pi$ ) e ligações de hidrogênio. Segundo Piccolo (2016), estas moléculas estão em equilibrio na fase aquosa do solo, e são estabilizadas pela adsorção hidrofóbica na superfície de aluminossilicatos ou óxidos de ferro e alumínio ou por complexos metálicos, divalentes e trivalentes presente no solo. 
Figura 2.6: Modelo Supramolecular do Ácido Húmico proposto por Piccolo (2001).

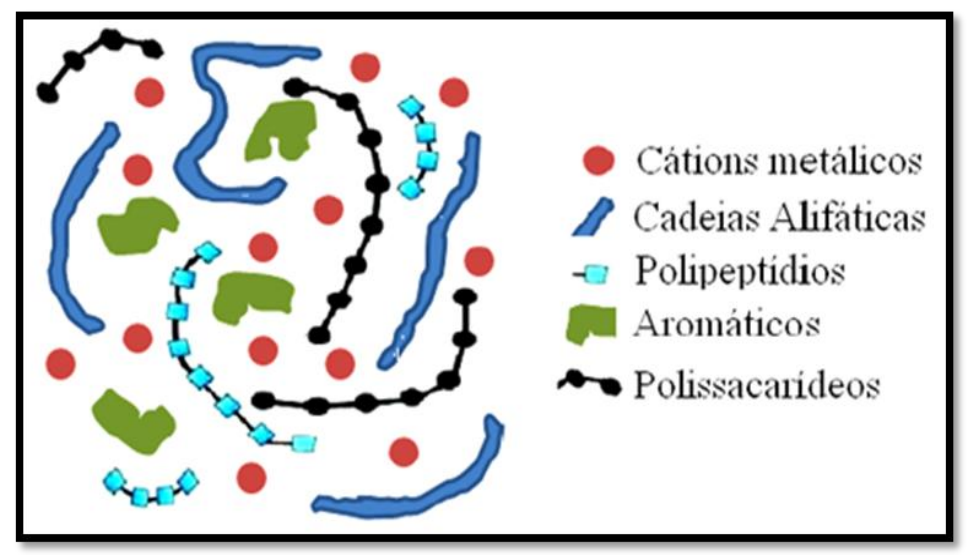

Fonte: adaptado de Piccolo (2001) - número da licença 4244180821686.

As substâncias húmicas podem ser fracionadas de acordo com a sua solubilidade em: ácidos húmicos (AH), ácidos fúlvicos (AF) e humina (HU) (Stevenson, 1994; Senesi et al 2007). Portanto, compreender a dinâmica dessas frações húmicas é fundamental para a avaliação da qualidade e da capacidade do solo em resistir às mudanças de suas propriedades físicas e químicas, que podem ser afetadas por diversos fatores, dentre eles: o clima, a água e a natureza do material de origem (Stevenson 1994; Senesi e Loffredo 1999).

Segundo Schmidt et al. (2011) antigamente as SH eram descritas como macromoléculas grande e complexas mais estáveis pertecentes a matéria orgânica. No entanto, os mesmo autores relatam que esses componentes representam apenas uma pequena parcela da fração pertencente à matéria orgânica e que possuem em sua estrutura moléculas menores e mais simples. Assim, moléculas derivadas de plantas tais como ácidos alcanóicos de cadeia longa, n-alcanos, lignina e outros grupos estruturais costumam persitir quando comparado à biomassa vegetal que sofre decomposição facilmente. Portanto, em solos minerais esses materiais persistentes tem a taxa de degradação mais rápido que a biomassa vegetal.

Recentemente, Lehmann e Kleber (2015) propuseram três modelos de degradação da matéria orgânica: (a) humificação clássica; (b) preservação seletiva e (c) decomposição progressiva. A humificação clássica vem de uma transformação ou síntese dos compostos em macromoléculas ricas em estruturas contendo carbono e nitrogênio resistente a decomposição. A preservação seletiva dita que os insumos orgânicos são compostos lábeis relativamente recalcitrante que serão decompostos por microoganismos e que serão exauridos quando esses microorganismos tiverem a capacidade de decompor esses compostos mais persistentes, tais como aromáticos, policondensados, alcanos. Por fim, a decomposição progressiva ou degradação biopolímera, vem com o conceito de que a matéria orgânica é constituída de uma 
série de fragmentos orgânicos de diferentes tamanhos e estágios de decomposição. A quantidade de carbono orgânico no solo supera a quantidade presente na atmosfera e na vegetação, podendo influenciar muito nas previsões da dinâmica da matéria orgânica, e consequentemente nas mudanças climáticas globais (Lehmann e Kleber, 2015).

Piccolo (2016) relata que a acumulação das substâncias húmicas no solo é um processo dinâmico, em que os subprodutos heterogêneos da degradação biótica e abiótica de tecidos vegetais e animais não estão ligados mais covalentemente em macropolímeros húmicos ramificados. Porém, são progessivamente protegidos da mineralização em superestruturas ligadas fracamente a componentes hidrofóbicos, que estão excluídos da água e não são mais bioacessíveis a mineralização. Esse processo também é conhecido como humificação. Nesse processo dinâmico da humificação, as substâncias húmicas são adsorvidas hidrofobicamente na argila do solo e/ou sorvido quimicamente por óxidos, e quando expostos a alterações conformacionais causados por ácidos orgânicos liberados das raízes de plantas ou da degradação microbiana, irá regular a fertilidade do solo, químicamente e físicamente. Assim, essas moléculas húmicas são capazes de percolar entre os horizontes do solo, e irão desempenhar um papel importante no crescimento de plantas, na estabilização da estrutura do solo por meio da formação de complexos organo-minerais, no controle de contaminantes e carbono com o decorrer do perfil do solo (Piccolo 2016).

\subsubsection{Frações Húmicas}

\subsubsection{1. Ácido Húmico e Ácido Fúlvico}

As frações húmicas, são distribuídas em três categorias: a fração insolúvel em todo intervalo de $\mathrm{pH}$, denominada humina, que está fortemente ligada a fração mineral do solo; a fração solúvel em todo intervalo de $\mathrm{pH}$, denominado ácido fúlvico; e a fração insolúvel em em pH ácido, denominada ácido húmico (Stevenson 1994). Devido a protonação dos grupos funcionais em $\mathrm{pH}$ menor há uma quebra da estrutura na fração ácido húmico, e consequentemente a precipitação das macromoléculas nessa faixa de $\mathrm{pH}$. As características dessas frações estão apresentadas na Figura 2.7. 
Figura 2.7: Caracterização das frações húmicas.

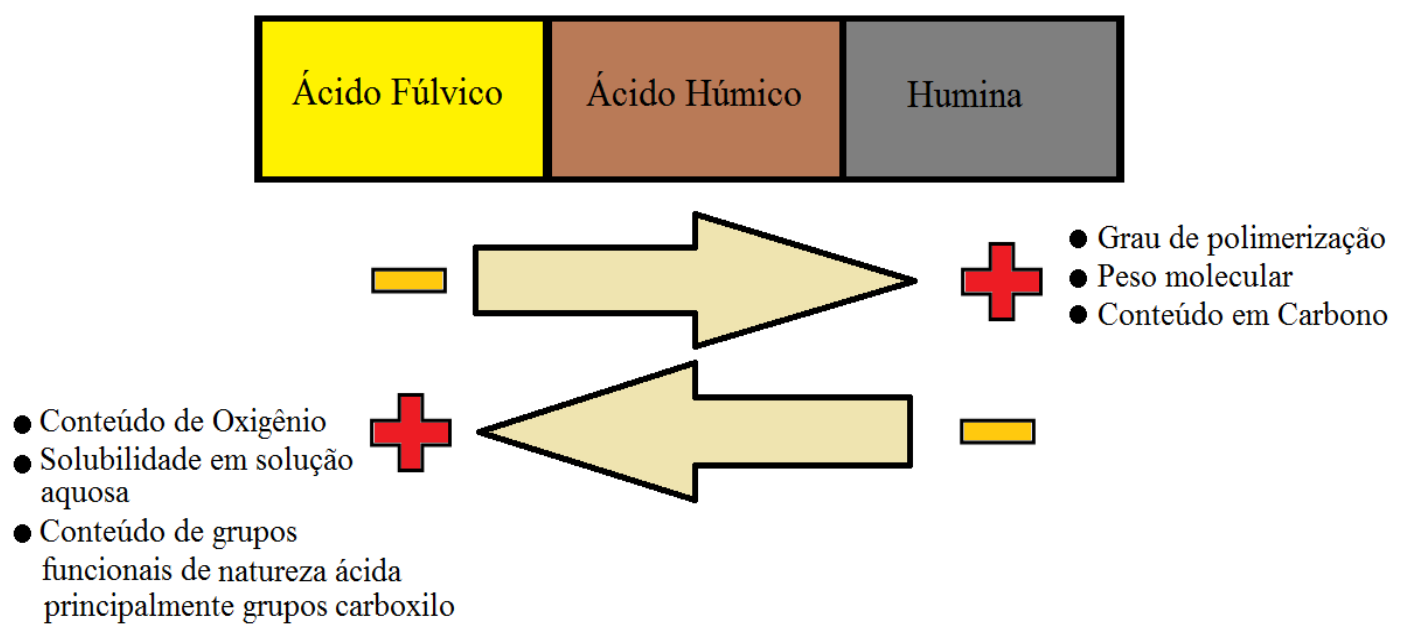

Fonte: Adaptado de Stevenson, 1994, p.44.

Conforme apresentado na Figura 2.7, as características das frações húmicas variaram de acordo com a sua estrutura, sendo que os ácidos fúlvicos apresentam menor grau de polimerização, e consequentemente menor conteúdo de carbono e peso molecular, e apresentando uma coloração amarelado quando em solução (Wolf, 1994). Já os ácidos húmicos, apresentam alto grau de polimerização, alta porcentagem de carbono (em torno $58 \%$ ) e peso molecular, e possuem uma coloração marrom escuro em solução aquosa (Stevenson, 1994; Zech et al., 1997). A acidez das frações de ácido húmico e fúlvico é devido ao hidrogênio dissociável em grupos alifáticos e aromáticos, em grupos fenóis e alcoóis hidroxílicos, pois o hidrogênio dissociável é capaz de realizar a troca de cátions da matéria orgânica (Hesse, 1971).

Os ácidos fúlvicos são classificados como material orgânico alcalino-extraível, o que incluí uma grande variedade de moléculas orgânicas de baixo peso molecular e formado de artefatos ácidos e básicos hidrolisáveis de matéria orgânica, e possuem peso molecular que podem variar de 100 a milhares de Dalton (Wolf, 1994). Os ácidos húmicos e fúlvicos, na forma desprotonada são capazes de formar complexos com cátions metálicos, formando os humatos e fulvatos, respectivamente (Hayes, 1985). Os AF e AH, com cargas aniônicas e desprotonados, respectivamente, podem formar complexos metálicos estáveis, cuja estabilidade dos complexos pode variar de acordo com o íon metálico, seguindo a seguinte ordem decrescente de estabilidade: $\mathrm{Cu}^{2+}>\mathrm{Ni}^{2+}>\mathrm{Co}^{2+}>\mathrm{Zn}^{2+}>\mathrm{Fe}^{2+}>\mathrm{Mn}^{2+}$ (Stevenson, 1994). 


\subsubsection{Humina}

Atualmente, há pouca informação disponível na literatura sobre a estrutura de humina (HU) em comparação com as outras duas frações, mesmo que a fração humina constitui entre $20 \%$ e 50\% das substâncias húmicas em massa do carbono presentes no solo (Rice e MacCarthy, 1989; Stevenson, 1994; Rice, 2001; Yang et al, 2004; Nichols e Wright, 2006). HU é definida como a porção extraída insolúvel que permanece em solução aquosa em todo $\mathrm{pH}$, e é operacionalmente tratada como se fosse resíduo restante da MOS (Stevenson, 1994; Rice, 2001). Esta fração húmica é também conhecida por se ligar fortemente a compostos orgânicos hidrofóbicos, e podem apresentar biopolímeros inalterados, tais como a lignina e polissacarídeos, em sua estrutura (Nearpass, 1976; Chiou et al., 2000). Além disso, possui grande quantidade de material inorgânico, como minerais, quartzos, silicatos aderidos a essa fração orgânica.

Rice e MacCarthy (1989) demonstraram que humina tinha características de uma mistura de lípidos de estruturas húmicas e compostos minerais (resíduo insolúvel). Rice (2001) demonstrou a importância de um conhecimento mais profundo sobre as estruturas das huminas e suas interações com o solo, permitindo uma melhor compreensão do papel na matéria orgânica e no sequestro de carbono. Estudos recentes mostraram que a estabilidade da humina no solo não é devido à baixa reatividade, mas devido a sua aglomeração de materiais húmicos, os quais são responsáveis por mecanismos de agregação das partículas no solo, e pode representar a maior parte do carbono presente no solo humificado (Benites et al., 2003; Lombardi et al., 2006).

De acordo com Stevenson (1994), humina consiste em uma variedade de materiais, tais como ácidos húmicos ligados a material mineral (argila) que não foram separados no processo de extração; e/ou materiais húmicos altamente condensados; e/ou insolúveis em meio básico; e/ou melaninas fúngicas e/ou substância parafínico que pode ser usado na recuperação de lípidos no solo. De acordo com este autor, a humina do solo pode ser dividida em duas frações com base na separação de seus microagregados, que consiste de polímeros modificados de lignina e outras partículas subcelulares de plantas retidos como microagregados.

\subsection{Caracterização das Substâncias Húmicas}

\subsubsection{Espectroscopia na região do Infravermelho com Transformada de Fourier}

A técnica de Espectroscopia na região do Infravermelho com Transformada de Fourier (FTIR) permite uma identificação de grupos funcionais e estruturas moleculares 
proporcionando uma melhor compreensão das vias de decomposição das frações húmicas, por meio dos movimentos vibracionais desses grupos (González Pérez et al., 2004; Spaccini e Piccolo, 2009; Rodríguez; Núñez, 2011; Li et al. 2014). O modo vibracional da molécula não é apresentado nos sinais de absorção dos espectros de FITR, entretanto a resposta é dada por meio do número de bandas de absorção. Essas bandas podem ser inseridas ou retiradas através das interações entre as moléculas, sendo que as ligações simples possuem bandas de absorção nas regiões de 1.200-700 $\mathrm{cm}^{-1}$ (Silverstein et al., 1994; Skoog, 2005; Zúniga 2006).

O espectro de FTIR é identificado por meio da determinação dos possíveis grupos presentes na estrutura da amostra; e diferenciação estrutural de uma molécula pode resultar em uma mudança na distribuição das bandas de absorção (Zúniga et al., 2008). Assim, em razão da diversidade de moléculas orgânicas presentes nas subtânicas húmicas, o espectro dessas pode apresentar uma sobreposição de bandas (Stevenson, 1994). Os principais grupos funcionais presentes nas frações húmicas estão apresentados na Tabela 2.2.

Tabela 2.2: Principais bandas obtidas para as frações húmicas empregando o Infravermelho.

\begin{tabular}{|c|c|}
\hline Frequência $\left(\mathrm{cm}^{-1}\right)$ & Descrição da banda \\
\hline 3390 & Banda larga de hidroxila. \\
\hline $3440-3380$ & Estiramento O-H em COOH, alcoóis ou fenóis e estiramento N-H. \\
\hline $3100-3030$ & Estiramento C-H em anéis aromáticos. \\
\hline $2800-3000$ & Banda de cera (estiramento de $\mathrm{CH}_{2}$ e $\mathrm{CH}_{3}$ alifático). \\
\hline $2940-2900$ & Estiramento $\mathrm{C}-\mathrm{H}$ em $\mathrm{CH}_{2}$ e $\mathrm{CH}_{3}$ alifáticos. \\
\hline $2860-2840$ & Estiramento $\mathrm{C}-\mathrm{H}$ em $\mathrm{CH}_{2}$ e $\mathrm{CH}_{3}$ alifáticos. \\
\hline $1725-1710$ & Estiramento $\mathrm{C}=\mathrm{O}$ em $\mathrm{COOH}$ (principalmente), cetonas alifáticas, aldeídos e ésteres. \\
\hline 1630 & Banda de carboxilatos, inclui $\mathrm{C}=\mathrm{C}$, $\mathrm{R}-\mathrm{COOH}, \mathrm{H}_{2} \mathrm{O}$ ou $\mathrm{RCONH}$. \\
\hline $1660-1630$ & $\begin{array}{l}\text { Estiramento } \mathrm{C}=\mathrm{O} \text { em amida (banda } \mathrm{I} \text { ), quinonas, ligação } \mathrm{H} \text { com } \mathrm{C}=\mathrm{O} \text { de cetonas conjugadas, } \\
\text { estiramento } \mathrm{C}=\mathrm{C} \text { em anéis aromáticos. }\end{array}$ \\
\hline $1620-1600$ & $\begin{array}{l}\text { Estiramento } \mathrm{C}=\mathrm{C} \text { em anéis aromáticos e estiramento } \mathrm{COO}-\text {, ligações fortes de } \mathrm{H} \text { com } \mathrm{C}=\mathrm{O} \text { em } \\
\text { cetonas conjugadas. }\end{array}$ \\
\hline $1545-1505$ & Deformação $\mathrm{N}-\mathrm{H}$ e estiramento $\mathrm{C}=\mathrm{N}$ em amida (banda II), estiramento $\mathrm{C}=\mathrm{C}$ em anéis aromáticos. \\
\hline $1470-1420$ & Deformação $\mathrm{C}-\mathrm{H}$ em $\mathrm{CH}_{2}$ e $\mathrm{CH}_{3}$ alifáticos, estiramento COO-. \\
\hline $1420-1380$ & $\begin{array}{c}\text { Deformação C-H em } \mathrm{CH}_{2} \text { e } \mathrm{CH}_{3} \text { alifáticos, deformação O-H e estiramento C-O em OH fenólico e } \\
\text { estiramento COO-. }\end{array}$ \\
\hline $1380-1350$ & $\begin{array}{c}\text { Deformação C-H em } \mathrm{CH}_{2} \text { e } \mathrm{CH}_{3} \text { alifáticos, estiramento C-OH em OH fenólico e estiramento } \\
\text { COO-. }\end{array}$ \\
\hline $1260-1225$ & Deformação O-H em COOH e estiramento C-O em COOH, fenóis, alcoóis e éteres aromáticos. \\
\hline 1061 & Banda de carboidrato ou polissacarídeos. \\
\hline $1080-1040$ & Estiramento C-O em alcoóis alifáticos, C-O-C de éteres e C-O em polissacarídeos. \\
\hline $1080-1000$ & Vibração de Si-O-Si e Si-O-Al (silicato) \\
\hline $800-600$ & Silicatos de granulação fina, de óxidos de ferro, goetita e hematita. \\
\hline
\end{tabular}

Fonte: Fontana 2009; Chapman et al. 2001; Russel e Fraser, 1994; Galves e Lombardi, 2010. 
Fu e Quan (2006) estudaram a complexação dos ácidos fúlvicos extraídos de solos da Província de Xinjiang (China) com óxidos de ferro presente na hematita e goethita empregando FTIR. Os autores verificaram a interação da ligação-troca envolvendo grupos funcionais carboxílicos dos AF com as superfícies da hematita e goethita. Os autores concluíram que as ligações dos óxidos de ferro com ácido fúlvico foi à seguinte ordem de afinidade: hematite > goetita. Jouraiphy e colaboradores (2008) estudaram os ácidos fúlvicos extraídos do lodo ativado da estação de tratamento de água residual de Khouribga (Marrocos). Segundo esses autores, verificaram que os ácidos fúlvicos apresentaram estruturas peptídicas e hidrocarbonetos que foram absorvidos na região de 1650-1560 e $1072 \mathrm{~cm}^{-1}$ nos espectros FTIR. Rodríguez e Núñez (2011) caracterizaram ácidos húmicos e fúlvicos empregando diversas técnicas dentre essas, a FTIR. Segundo esses autores os ácidos fúlvicos apresentam maior quantidade de grupamentos carboxílicos quando comparados aos ácidos húmicos que apresentaram maior presença de grupamentos aromáticos, corroborando com outros estudos descritos na literatura (Chen et al. 2002; Abbt-Braun et al. 2004; Giovanela et al. 2010). Deste modo, a aplicação da Espectroscopia na região do Infravermelho fornece informações importantes sobre sua natureza e a forma de disposição dos principais grupos funcionais presentes na estrutura das SH.

\subsubsection{Espectroscopia de Fluorescência de luz UV-Vis}

A fluorescência é um fenômeno de fotoluminescência, em que as moléculas são excitadas por uma radiação eletromagnética a um estado excitado singleto, e ao retornarem ao estado fundamental pode ocorrer à emissão de um fóton (Lakowicz, 1999). Os fluoróforos são grupos de cromóforos que emitem luz em comprimento de onda específico. O fenômeno de fluorescência ocorre principalmente em compostos orgânicos que contêm grupos aromáticos em sua estrutura (Skoog, 2005).

A espectroscopia de fluorescência é uma técnica seletiva e sensível, cujos espectros permitem determinar a composição e a configuração da matéria orgânica e de suas frações húmicas de várias origens. Essa técnica permite um estudo seletivo dos principais grupos cromóforos que fornecem a fluorescência na amostra em determinados comprimentos de onda específicos; esses grupos são denominados fluoróforos (Coble, 1996; Filella et al. 2005; Ziegelgruber et al. 2013). A utilização desta técnica em amostras ambientais, especialmente nas frações húmicas, fornece dados importantes sobre a estrutura química e a boa sensibilidade. Algumas metodologias têm sido sugeridas na literatura empregando essa técnica para avaliação do índice de humificação para as substâncias húmicas (Kalbitz et al. 
1999; Milori et al. 2002).

A modalidade matriz Emissão-Excitação (EEM) é uma técnica mais completa da análise de fluorescência, a qual permite que um conjunto simples ou uma mistura de componentes fluorescentes presentes nas frações húmicas possa ser avaliado, proporcionando, assim, uma impressão digital da amostra (Chen et al. 2002; Peuravuori et al. 2002; Sierra et al. 2005; Rodríguez et al. 2014; Zhu et al. 2014). Além disso, o espectro de EEM pode ser utilizado para a caracterização qualitativa e quantitativa da matéria orgânica, quando combinado com as técnicas estatísticas multivariadas avançadas, tais como Análise de Fator Paralelo (CP/PARAFAC), que pode decompor o sinal complexo dos espectros de fluorescência em componentes simples e independentes. EEM-CP/PARAFAC é uma técnica potencialmente útil na avaliação das amostras complexas, tais como frações húmicas. Esta técnica permite a avaliação da decomposição dos componentes fluorescentes, independente do complexo formado na EEM (Luciani et al. 2009; Santín et al. 2009; Ziegelgruber et al. 2013; Zhu et al. 2014).

\subsubsection{Espectroscopia de Supressão de Fluorescência}

A determinação das propriedades químicas da matéria orgânica, assim como a sua interação com espécies metálicas, é uma ferramenta importante para compreensão da sua estrutura. As SH são formadas por anéis aromáticos e por grupos funcionais reativos que são responsáveis pela elevada capacidades de complexação com metais, especialmente espécies metálicas divalentes e trivalentes, tais como, cobre, alumínio e ferro.

A fluorescência de supressão, também denominada análise de quenching, é um processo que diminui a intensidade de fluorescência de uma amostra, resultando no decaimento do sinal de fluorescência devido às interações moleculares que ocorrem no meio (Manciulea et al. 2009). Essas interações incluem reações no estado excitado, rearranjos moleculares, transferência de energia, formação do complexo no estado fundamental e da energia de colisão (Esteves da Silva et al. 1998; Mounier et al. 2011). O quenching na amostra pode ser ocasionado por dois mecanismos, supressão dinâmica (quenching dinâmica) e/ou supressão estática (quenching estático) conforme exibido na Figura 2.8. O quenching dinâmico é um processo em que o fluoróforo e o agente supressor (por exemplo, metal) entram em contato e envolvem a transferência de energia entre as moléculas no estado excitado (processo colisional). Enquanto que o quenching estático é um processo em que são formados os complexos não fluorescentes do fluoróforo no estado fundamental (processo de complexação de equilíbrio) (Kumke et al., 1998; Manciulea et al. 2009; Wu et al. 2013). 
Figura 2.8: Mecanismo de supressão de Fluorescência

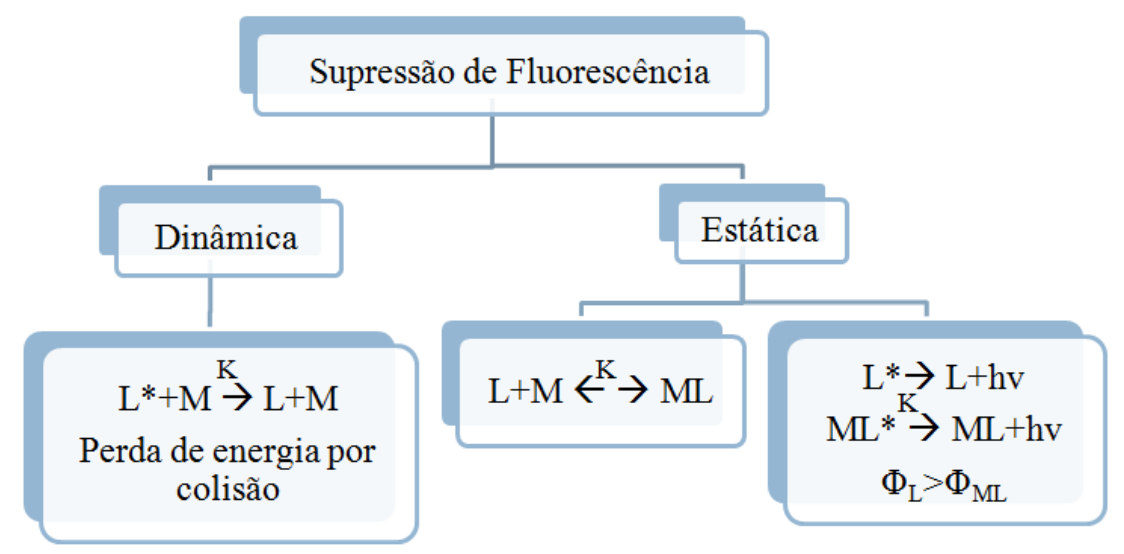

Fonte: Autoria própria.

Luster e colaboradores (1996) avaliando os diferentes comportamentos de análise de quenching, concluíram que há diferentes tipos de ligação do metal cobre com a MO, os quais são: ligações fracas, ligações fortes e ligações de complexos muito fortes. Smith e Kramer (2000) propuseram um método multi-resposta, capaz de explicar todos os sítios de fluorescência disponíveis da ligação cobre-MO. Segundo esses autores foram identificados cinco componentes fluorescentes diferentes para MO usando a técnica de resolução espectral. Estudos realizados por Yamashita e Jaffe (2008), empregando análise de fator paralelo, mostraram a contribuição de oito componentes que são responsáveis pela ligação entre cobreMO. Nas substâncias húmicas a supressão de fluorescência é uma característica essencial obtida quando essas subtâncias estão em contato com íons metálicos paramagnéticos. Assim, a sensibilidade e simplicidade da fluorescência de quenching torna-a uma técnica viável capaz de analisar essas interações a nível molecular (Esteves da Silva et al. 1998).

\subsubsection{Espectroscopia de Fluorescência Resolvida no Tempo}

A espectroscopia de fluorescência resolvida no tempo (FRT) é empregada para avaliar as interações e os movimentos moleculares de uma amostra que ocorrem no intervalo de tempo de pico e nano segundos. Assim, essa técnica torna-se útil, pois é capaz de investigar a estrutura e dinâmica de macromoléculas biológicas (proteínas e ácidos nucléicos, por exemplo).

A fluorescência resolvida no tempo monitora o que ocorre com um fluoróforo presente em uma amostra. Essa técnica é empregada para medir o decaimento da intensidade total de fluorescência da molécula após a excitação ou emissão, permitindo a determinação do tempo de vida de fluorescência desses fluoróforos, ou ser empregada para caracterizar os 
movimentos moleculares desse fluoróforo (Millar, 1996).

Devido a sua elevada sensibilidade, alta seletividade e por não ser destrutivo a técnica de espectroscopia de fluorescência resolvida no tempo torna-se importante para análise de íons metálicos fluorescentes (Collins et al. 2011). Os diferentes decaimentos que as espécies químicas de um íon metálico sofrem torna essa técnica seletiva (Lukman et al. 2012).

Estudos realizados por Lukman e colaboradores (2012), avaliaram a especiação de $\mathrm{Eu}^{3+}$ presente nas $\mathrm{SH}$ de várias origens com auxílio da espectroscopia de fluorescência resolvida no tempo. Nesse estudo os autores aplicaram nos resultados diferentes tratamentos estatísticos, dentre eles o PARAFAC, e observaram a presença de três diferentes fatores (A, B e C) que correspondiam a diferentes espécies de $\mathrm{Eu}^{3+}$ em função do $\mathrm{pH}$, que obtiveram diferentes tempos de vida. Analisando os resultados, os autores concluíram que o fator A estava livre na solução. Enquanto que o fator B estava vinculado aos grupos funcionais das SH e o fator C estaria ligado aos sítios ativos das SH devido à abundância deste fator.

Segundo Prendergas (1991), a fluorescência resolvida no tempo é uma ferramenta, no campo da espectroscopia que permite uma análise específica da estrutura e dinâmica de macromoléculas biológicas, e que permitirá um grande avanço em muitas áreas de investigação da biologia. Na literatura há muitos estudos que abordam o uso da espectroscopia de fluorescência resolvida no tempo na caracterização da estrutura, dinâmica e interações de proteínas e ácidos nucléicos, especialmente o triptofano, devido a sua fluorescência ser muito sensível a fatores ambientais. No entanto, há poucos estudos na literatura que abordam o uso dessa técnica na caracterização dos fluoróforos das frações húmicas, especialmente os ácidos húmicos e fúlvico.

\subsubsection{Espectroscopia de Fluorescência Induzida a Laser}

A Fluorescência induzida a laser (Laser Induced Flourescence Spectroscopy - LIFS) é uma técnica promissora o qual é baseado na emissão de fluorescência de componentes aromáticos presentes no solo (Martins et al. 2011). Os principais fluoróforos da MOS com alta fluorescência são sistemas moleculares contendo pares de elétrons isolados tais como $\mathrm{C}=\mathrm{O}$, aromáticos, fenólicos, quinonas e anéis insaturados de sistemas alifáticos (Milori et al. 2011).

A determinação das propriedades óticas da matéria orgânica é uma importante ferramenta para a compreensão estrutural das frações húmicas. A LIFS aplicado aos solos é uma técnica recente que demonstra ser eficaz na análise de MOS proporcionando resultados rápidos e sensíveis, limpos, e pode ser aplicada a amostra sem pré-tratamento (Milori et al, 2006a, 2011b; Martins et al, 2011). 
Bayer e coautores (2000) encontraram alto grau de humificação para amostras de cultivo convencional bem como baixo conteúdo de carbono comparado a solos que não passou por um processo de manejo. Esses autores observaram que a humificação foi caracterizada por radical livre de semiquinona, os quais foram atribuídos à presença de carbono aromático ou carbono em um estado de decomposição mais estável, o que deve estar associado ao aumento e acumulação de resíduo vegetal em solo não cultivado. Assim, a qualidade da matéria orgânica do solo aumenta de acordo com o tipo de preparo do solo.

Milori et al. (2006) avaliaram o índice de humificação $\left(\mathrm{H}_{\mathrm{LIFS}}\right)$ de $\mathrm{MO}$ em solos inteiros usando uma abordagem baseada na excitação na região do azul que irá fluorescer estruturas mais complexas, tais como anéis aromáticos conjugados. Assim, o sinal de emissão de fluorescência normalizada por carbono é proporcional ao índice de humificação da matéria orgânica do solo.

\subsubsection{Espectroscopia de Emissão Ótica com Plasma Induzido por Laser}

A Espectrometria de emissão ótica com plasma induzido por laser (Laser Induced Breakdown Spectroscopy - LIBS) é uma técnica espectro analítica baseada na observação de emissão de átomos, íons e espécies moleculares em um microplasma formado pela interação entre amostra e pulsos de laser de alta energia. Em um espectro LIBS a identificação das espécies presentes na amostra é baseada no comprimento de onda de emissão, o qual é característico para cada elemento, e a quantidade da espécie é determinada pela intensidade (área) dos picos.

Durante o processo analítico amostra é irradiada por um pulso de laser de alta energia que a absorve. Essa absorção causa aquecimento no local no qual o pulso atingiu o material, resultando na evaporação ou sublimação desse material. A alta temperatura de ablação do material gera pequena nuvem de plasma. A ablação do material provoca a excitação de espécies atômicas e iônicas, e durante essa colisão as espécies excitadas, muda do estado mais energético para o estado menos energético. Ocorrendo assim, a liberação de fóton e ao retornarem ao seu estado fundamental emitem radiação eletromagnética em comprimentos de onda característicos permitindo a determinação dos principais elementos que compõem as substâncias húmicas (Ferreira et al. 2011).

O LIBS é baseado em três etapas: ablação estequiométrica; emissão espectral e o equilíbrio termodinâmico. São inúmeras as vantagens do emprego da técnica LIBS: trata-se de uma técnica simples e versátil, permitindo a detecção dos elementos químicos em qualquer estado físico (sólido, líquido, ou gasoso). Essa técnica se torna mais sensível para elementos 
mais leves da tabela periódica, tais como $\mathrm{He}, \mathrm{Li}, \mathrm{Be}, \mathrm{B}, \mathrm{C}, \mathrm{N}$ e S, sendo que seu limite de detecção está na ordem de $\mu \mathrm{g}$ a g; a maioria das amostras não precisa de um pré-tratamento antes da análise, ou seja, o LIBS requer pouca ou nenhuma preparação da amostra; fornece resultados em tempo-real; é necessária pequena quantidade da amostra para ser analisada, permitindo a realização da análise em situ (Harmon et al. 2013). Além disso, a técnica LIBS apresenta simplicidade e versatilidade na detecção e medição, tornando-se uma técnica voltada aos princípios de química verde (Hahn e Omenetto, 2012; Ferreira et al., 2014; Nicolodelli et al., 2014; Senesi e Senesi, 2016).

\subsubsection{Ressonância Magnética Nuclear}

Uma ferramenta que permite a identificação de grupos funcionais e estruturas moleculares é a Espectroscopia de Ressonância Magnética Nuclear do isótopo ${ }^{13}$ carbono. Esta técnica é capaz de fornecer características conformacionais dos núcleos de carbono presentes na amostra, permitindo estimar a quantidade relativa e os tipos de carbono, alifático e aromático presente nas amostras de substâncias húmicas. A técnica de ${ }^{13} \mathrm{C}$ RMN consiste em irradiar um pulso curto e potente de radiofrequência, que excita todos os núcleos de ${ }^{13} \mathrm{C}$ existentes na amostra. Os dados são digitalizados automaticamente e guardados em computador em uma série de pulsos repetidos, que acumula os pulsos, construindo os sinais (Fonte: Skoog, 2002).

Os espectros de ${ }^{13} \mathrm{C}$ RMN das substâncias húmicas extraídas do solo são geralmente divididos em quatro regiões de deslocamento químico, os quais são representados pelo carbono: alquilo (0- 45 ppm), alquil-oxigênio (45-110 ppm), aromático (110-160 ppm) e carboxílico (160-210 ppm). Especificamente em 15 ppm refere-se a carbono de grupos com metil no final da cadeia; em 30-45 ppm atribuí-se a carbono alquil sem substituição que incluem cadeias lineares de carbono metilenos, e em 45-46 ppm a carbono de alquilo substituído encontrado em aminas e em 56 ppm a carbono presente em grupos metóxi. Enquanto que entre 65-95 ppm pode ser atribuído a carbono ligado a substituintes de oxigênio e anéis de carbono em carbohidratos e carbonos presentes em éteres. Já em 95-110 ppm atribuí-se a dois-oxigênio substítuido em carbonos alifáticos e carbono anomérico em carbohidrato (105 ppm); em 160-190 ppm atribui-se aos grupos carboxílicos, amidas e carbono de ésteres, especialmente ao redor de $170 \mathrm{ppm}$ pode ser referido a presença de carbonos ligados a grupos de ésteres ou amidas (Simpson e Simpson, 2009).

A MO presente no solo pode conter diferentes grupos, os quais podem variar dependendo do tipo de solo, efeitos pedogenéticos e do uso desse solo (Piccolo e Conte, 
1997). Assim, sinais entre 72 a 105 ppm podem ser atribuídos a presença de polissacarídeos, enquanto que, sinal em 30 ppm, pode estar associado a presença de carbonos alifáticos, presentes em lípideos, biopolímeros alifáticos, ácidos graxos e cutina. Já sinais largos, entre 30 e 55 ppm pode atribuir a presença de proteínas ou peptídeos. Os sinais entre, 56, 119, 130 e 150 ppm contribuem para a presença de carbono de: metoxilas; aromáticos protonados e substituídos; e carbonos fenólicos, presentes na lignina. Sinal alto em 130 ppm do carbono aromático substituído pode estar associado a uma estrutura de lignina que foi alterada. $\mathrm{O}$ sinal em 175 ppm é derivado de grupos carboxilo e amidas (Kögel-Knabner, 1997).

Segundo Kögel-Knabner (1997), a quantidade do carbono alquil aumenta com a biodegradação da $\mathrm{MO}$, diminuindo a quantidade do carbono O-alquil. Essa relação pode ser utilizada como um indice do grau de decomposição, o qual pode ser empregado dentro de um perfil do solo ou com um conjunto de materiais de mesma origem, uma vez que a natureza do grupo alquil e O-alquil podem variar durante o processo de biodegradação.

Conforme, Segnini e colaboradores (2013), a presença de íons paramagnéticos nos solos pode causar interferência na maioria das técnicas espectroscópicas. A presença de íons paramagnéticos (especialmente $\mathrm{Fe}^{3+}$ ) na amostra pode acarretar o quenching da intensidade do sinal, devido ao encurtamento dos tempos de relaxação do carbono presente nos grupos funcionais. Assim, o carbono ligado diretamente a íons paramagnéticos, será invisível ao RMN, tornando-se a interpretação quantitativa dos espectros difícil e às vezes impossível de analisar (Kögel-Knabner, 1997). Entretanto, a técnica ${ }^{13} \mathrm{C}$ RMN tem sido empregada para investigar a funcionalidade da MO e de suas frações húmicas, tanto qualitativamente como quantitativamente, a qual permite distinguir entre diferentes núcleos de carbono presentes em sua estrutura, tornando uma técnica promissora e de grande importância na caracterização da matéria orgânica do solo.

\subsection{Qual a importância do estudo}

A matéria orgânica do solo atua na ciclagem de nutrientes, retenção de água, controle térmico, dentre outros fatores. Estudos que visam avaliar as características estruturais e as propriedades complexantes da MO são fundamentais para compreender os processos de formação do solo. Os Espodossolos na região Amazônica são caracterizados por armazenarem grandes quantidades de carbono orgânico nos horizontes superficiais e profundos. Em função da dificuldade de acesso, pouco se sabe a respeito do comportamento da matéria orgânica na gêneses destes solos. 
O modelo macromolecular de estrutura química das $\mathrm{SH}$, onde a humificação aumenta com o decorrer do tempo, não explica muitos comportamentos da MO destes solos e, de certa forma, dificulta o entendimento da gêneses dos espodossolos Amazônicos. Assim, lançou-se a seguinte hipótese: “O processo de Podzolização é diretamente influenciado pelas propriedades química das substâncias húmicas. As diferentes frações húmicas agem de maneira seletiva no processo". Para testar essa hipótese, este trabalho buscou o auxílio de diversas técnicas espectroscópicas, datação de carbono e de análise elementar. As implicações de um modelo estrutural mais simples e com maior mobilidade pode impactar muito a forma que encaramos o acúmulo de carbono no solo e sua estabilidade. É importante enfatizar, que neste novo modelo em que há presença de um carbono com estruturas mais simples torna-se mais frágil à decomposição. Assim, a conservação desses solos torna-se fundamental para evitar grandes fluxos de emissão de carbono por exposição de perfis profundos ou alteração do regime de chuvas, impondo prolongados períodos de seca e aumentando atividade microbiológica do solo, e consequentemente emissão de $\mathrm{CO}_{2}$. 
Capítulo 3 - Objetivos 


\section{Objetivo Geral}

Estudar a matéria orgânica de Espodossolos Amazônicos com o intuito de entender o processo de gênesis destes solos. Para tanto, o trabalho visa avaliar as características estruturais da Matéria Orgânica e suas frações Húmicas e suas propriedades de complexação com metais em perfis de Espodossolos Amazônicos.

No estudo estrutural foram empregadas diversas técnicas espectroscópicas: Espectroscopia de Infravermelho com Transformada de Fourier (FTIR), Espectroscopia de absorção de radiação no ultravioleta-visível (UV-Vis), Espectroscopia de Fluorescência, Espectroscopia de Supressão de Fluorescência, Espectroscopia de Ressonância Magnética Nuclear (RMN), Espectroscopia de Fluorescência Induzida por Laser (LIFS) e a Espectroscopia de Fluorescência Resolvida no Tempo (FRT). Além disso, foram empregadas técnicas de análise elementar para avaliar a interação com metais: Espectrometria de Absorção e Emissão Atômica no modo Chama e/ou Forno de Grafite e Espectroscopia Emissão Óptica com Plasma Induzido por Laser (LIBS).

Detalhando um pouco melhor o estudo, podem-se considerar os seguintes objetivos específicos:

1. Avaliar as características estruturais e a humificação da MO dos solos da região Amazônica;

2. Correlacionar o índice de humificação com a datação de carbono $\left({ }^{14} \mathrm{C}\right)$ para cada horizonte de solo coletado;

3. Avaliar as propriedades de complexação e interação da MO dos solos e suas frações húmicas com os metais. 
Capítulo 4 - Parte Experimental 


\section{Parte Experimental| 2017}

\section{1. Áreas de Estudo}

A área de estudo situa-se no Município de Barcelos, na bacia do Rio Demeni, afluente médio do Rio Negro (Figura 4.9). Na Figura 4.9 apresenta-se o sítio de estudo (polígono tracejado em preto) no qual foi estudada uma transecção de quatro solos do tipo Espodossolo. A geologia regional é representada por sedimentos da Formação Içá, cujos sedimentos mais recentes são encontrados nas várzeas atuais. De acordo com o IBGE (2012), Latossolos, Espodossolos e Gleissolos são os tipos de solos mais comuns nesta região. O clima é tipicamente equatorial, caracterizado por temperatura média anual de $25^{\circ} \mathrm{C}$ e por elevada pluviosidade (cerca de $3000 \mathrm{~mm}$ ), sem estação de seca pronunciada.

Figura 4.9: Localização da área de estudo na região Amazônica.

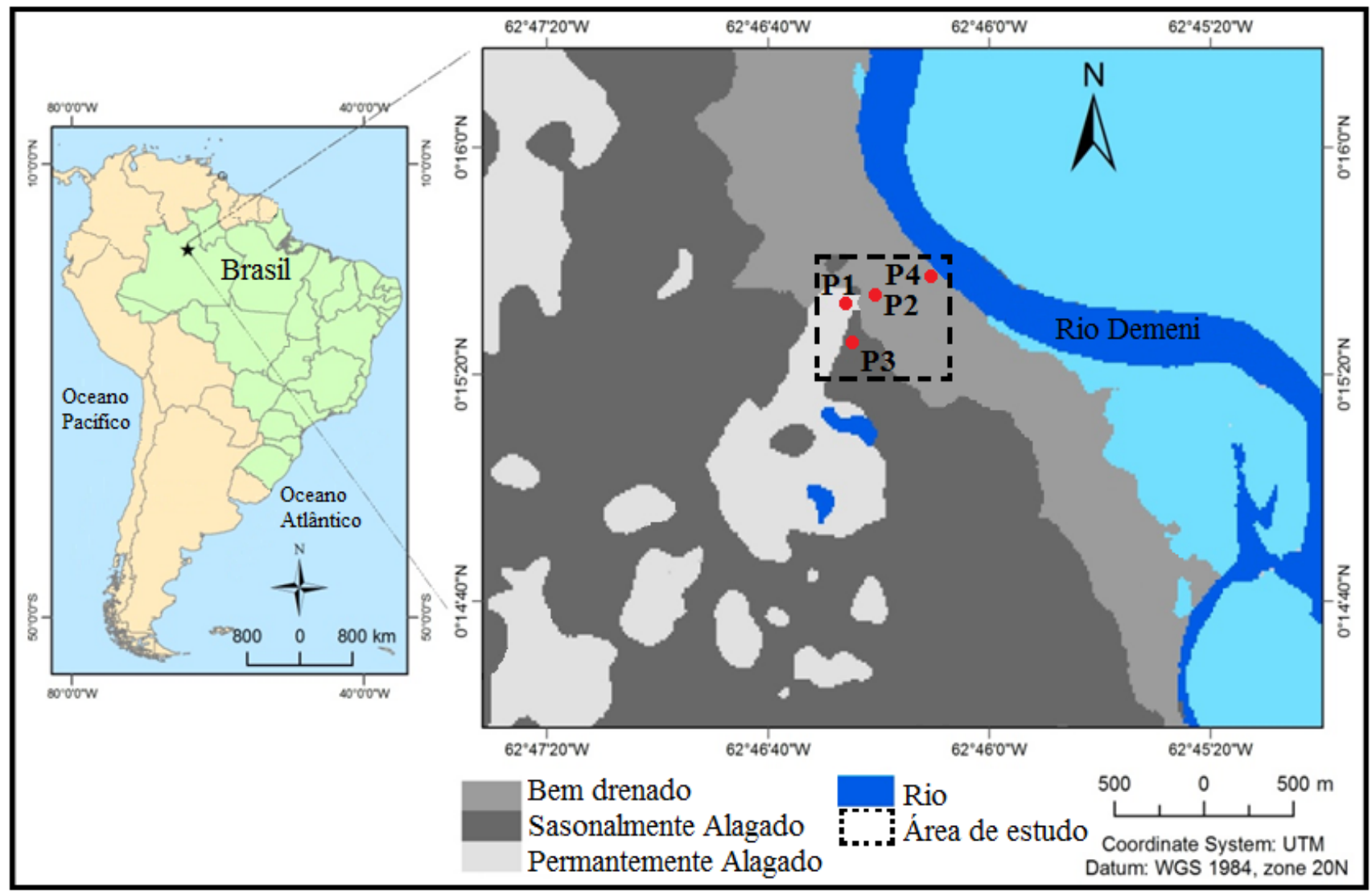

Fonte: Cedido por Dr. Osvaldo Pereira.

Os solos estudados foram classificados como Espodossolo (EMBRAPA, 2006; IBGE, 2012), os quais foram amostrados em perfis, localizados em trincheiras alinhadas em transecto Leste-Oeste, a partir da margem do Rio Demeni até depressão localizada no interflúvio, conforme apresentado na Figura 4.10. A partir do centro da depressão existem: 
Espodossolo permanentemente alagado coberto por campina herbácea (Ponto 1); dois Espodossolos sazonalmente alagados cobertos por vegetação de campina e campinarana árborea (Pontos 2 e 3); Espodossolo bem drenado de floresta e vegetação de campinarana (Ponto 4).

Figura 4.10: Representação da área de estudo e dos perfis de solos na transecção. Vale ressaltar que o Solo P3 como mostra o mapa da localização da área (Figura 4.9) está deslocado, por isso não se encontra no perfil.

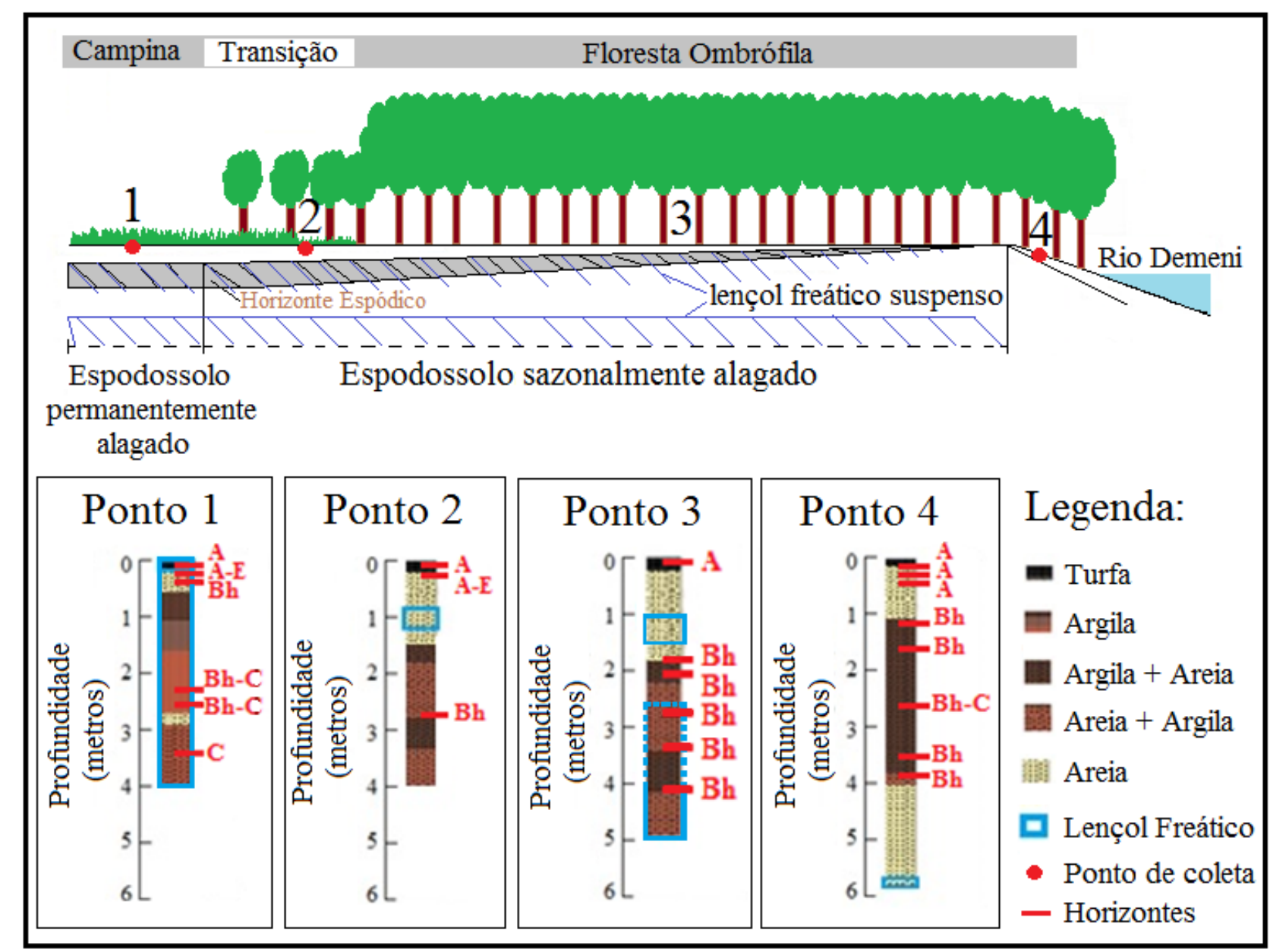

Fonte: adaptado Guimarães, 2014 e Pereira et al., 2013.

\subsection{Características físicas dos Espodossolos estudados}

Os Espodossolos discutidos nesse trabalho apresentaram uma textura arenosa predominantemente de quartzo conforme exibido na Tabela 2.3. 


\section{Parte Experimental| 2017}

Tabela 2.3: Composição granulométrica (Pereira et al., 2013) dos vários horizontes das amostras de Espodossolos: Perfil 1, 2, 3 e 4. Os horizontes destacados, A, A-E, Bh, Bh-C e C, são horizontes que estão sob influência do lençol freático suspenso.

\begin{tabular}{|c|c|c|c|c|c|c|c|c|c|}
\hline Solos & $\begin{array}{c}\begin{array}{c}\text { Profundidade } \\
\text { (cm) }\end{array} \\
\end{array}$ & $\begin{array}{c}\text { Tipo de } \\
\text { Horizonte }\end{array}$ & $\begin{array}{c}\text { Gibbsita } \\
(\%)\end{array}$ & $\begin{array}{c}\text { Caolinita } \\
(\%)\end{array}$ & $\begin{array}{c}\text { Goethita } \\
(\%)\end{array}$ & $\begin{array}{c}\text { Areia } \\
\text { grossa }(\%)\end{array}$ & $\begin{array}{c}\text { Areia } \\
\text { Fina }(\%)\end{array}$ & $\begin{array}{l}\text { Silte } \\
(\%)\end{array}$ & $\begin{array}{c}\text { Argila } \\
(\%)\end{array}$ \\
\hline \multirow{6}{*}{$\begin{array}{l}\text { Perfil } \\
1\end{array}$} & $0-15$ & $\mathrm{~A}$ & 0,00 & 0,00 & 0,00 & $*$ & $*$ & $*$ & $*$ \\
\hline & $15-30$ & A-E & 0,00 & 0,00 & 0,00 & 13,24 & 45,13 & 40,63 & 1,00 \\
\hline & $40-50$ & Bh & 0,00 & 0,00 & 0,00 & 14,47 & 45,25 & 37,26 & 3,02 \\
\hline & 240 & Bh-C & 0,00 & 8,76 & 0,00 & $*$ & $*$ & $*$ & $*$ \\
\hline & 260 & Bh-C & 0,00 & 3,28 & 0,00 & 40,92 & 48,96 & 5,26 & 4,86 \\
\hline & 350 & $\mathrm{C}$ & 0,00 & 1,66 & 0,00 & 48,80 & 46,90 & 2,79 & 1,50 \\
\hline \multirow{3}{*}{$\begin{array}{l}\text { Perfil } \\
2\end{array}$} & $0-15$ & $\mathrm{~A}$ & 0,00 & 0,00 & 0,00 & 18,16 & 64,74 & 16,60 & 0,50 \\
\hline & $15-30$ & A-E & $*$ & $*$ & $*$ & $*$ & $*$ & $*$ & * \\
\hline & 290 & Bh & * & $*$ & * & * & $*$ & * & $*$ \\
\hline \multirow{6}{*}{$\begin{array}{l}\text { Perfil } \\
3\end{array}$} & $0-15$ & A & 0,00 & 0,00 & 0,00 & 12,91 & 55,56 & 30,53 & 1,00 \\
\hline & $165-175$ & Bh & 0,00 & 2,09 & 0,00 & 37,72 & 41,07 & 15,66 & 5,55 \\
\hline & $180-183$ & Bh & $*$ & $*$ & $*$ & $*$ & $*$ & $*$ & $*$ \\
\hline & $210-215$ & Bh & $*$ & $*$ & * & $*$ & $*$ & $*$ & $*$ \\
\hline & $280-310$ & Bh & 0,00 & 1,17 & 0,00 & 70,08 & 23,74 & 0,33 & 5,84 \\
\hline & $335-350$ & Bh & 0,00 & 4,25 & 0,00 & 9,65 & 81,49 & 4,31 & 4,54 \\
\hline \multirow{8}{*}{$\begin{array}{c}\text { Perfil } \\
4\end{array}$} & $0-20$ & $\mathrm{~A}$ & 0,20 & 0,38 & 0,00 & 64,62 & 30,53 & 4,35 & 0,50 \\
\hline & $20-30$ & A & 0,51 & 1,22 & 1,49 & 48,35 & 44,30 & 5,85 & 1,51 \\
\hline & $30-40$ & A & 0,43 & 1,45 & 1,72 & $*$ & $*$ & $*$ & $*$ \\
\hline & $110-120$ & $\mathrm{Bh}$ & $*$ & $*$ & $*$ & $*$ & $*$ & $*$ & $*$ \\
\hline & $170-180$ & $\mathrm{Bh}$ & * & $*$ & $*$ & $*$ & $*$ & $*$ & $*$ \\
\hline & $270-280$ & $\mathrm{Bh}$ & $*$ & $*$ & $*$ & $*$ & $*$ & $*$ & $*$ \\
\hline & $370-380$ & $\mathrm{Bh}$ & 0,52 & 2,07 & 1,06 & 30,31 & 59,52 & 7,16 & 3,02 \\
\hline & $380-390$ & $\mathrm{Bh}$ & $*$ & $*$ & $*$ & $*$ & $*$ & $*$ & $*$ \\
\hline
\end{tabular}

* Não foi realizado análise dessa amostra (Fonte: adaptado de Pereira et al., 2013)

Fonte: Autoria própria.

Nos Espodossolos hidromórficos, sazonalmente alagados dos Perfils 1, 2 e 3 não foram identificados óxidos ou oxihidróxidos de ferro, uma vez que estes solos estão sob condições de hidromorfia na maior parte do ano. No Espodossolo bem drenado (Perfil 4) verificou-se alternância de períodos redutores e oxidantes, o que permitiu a formação da goethita, com teores entre 1,0 e 1,7 \%. Isto pode estar relacionado à sua localização que permitem tanto a mobilização como a precipitação da goethita, em razão do controle exercido pela oscilação do nível dos aquíferos suspensos. Os períodos mais chuvosos propiciam a mobilização do ferro reduzido, enquanto nos períodos menos chuvosos, o nível dos aquíferos diminui e as condições oxidantes permitem a precipitação do ferro na forma de goethita.

Os solos estudados apresentam predominantemente textura arenoso-quartzosa com 
diferentes distribuições de areia grossa e fina, silte e argila em cada horizonte do solo. Areia fina e o silte são as texturas dominantes em todos os Perfils de solo, com caulinita e gibssita com minerais acessórios presentes nos horizontes mais profundos em quantidades variadas. Os horizontes $\mathrm{Bh}$ em profundidade tem coloração heterogenea, formando Bh sub-horizonte variando da cor preta a marron avermelhado ou amarelo brunado.

Assim, o Perfil 1 é um Espodossolo sem desenvolvimento de horizonte E bem diferenciado, devido à condição alagada permanente em uma área de campo aberto. Os Perfis 2 e 3, são Espodossolos tipicamente Amazônico, com horizonte E bem diferenciado e com a presença de água permanente situado acima do horizonte Bh. Por fim, o Perfil 4, é um Espodossolo bem desenvolvido, onde o horizonte E, foi removido por processo de erosão consecutiva do desenvolvimento do meandro do rio Demeni.

\subsection{Amostragem dos solos e Fracionamento Químico das Frações Húmicas}

A amostragem foi efetuada em horizontes representativos de cada solo, que foram previamente descritos (item 4.1.). Os procedimentos de amostragem, preservação e preparação das amostras seguiram métodos descritos na literatura (Boulet et al. 1982; Santos et al., 2005; Embrapa, 2006).

A partir de um estudo preliminar utilizando a Espectroscopia de Fluorescência Induzida por Laser, selecionou-se amostras que foram fracionadas em Ácidos Húmicos (AH), Ácidos Fúlvicos (AF) e Humina (HU), totalizando 23 amostras de diferentes profundidades (Figura 4.10, item 4.1). A extração dos Ácidos Húmicos, Fúlvicos e Humina, seguiram as recomendações descritas pela Sociedade Internacional de Substâncias Húmicas (IHSS), Rice e MacCarthy (1989) e Swift (1996). Cabe ressaltar que todas as amostras foram liofilizadas. As sucessões verticais descendente das amostras dos solos selecionados no fracionamento químico para os quatros Espodossolos utilizados foram:

- Solo 1: P1 A 0-15, P1 A-E 15-30, Pl Bh 40-50, P1 Bh-C 240, P1 Bh-C 260, P1 C 350;

- Solo 2: P2 A 0-15, P2 A-E 15-30, P2 Bh 290;

- Solo 3: P3 A 0-15, P3 Bh 165-175, P3 Bh 180-183, P3 Bh 210, P3 Bh 280-310, P3 Bh 335350 ;

- Solo 4: P4 A 0-20, P4 A 20-30, P4 A 30-40, P4 Bh 110-120, P4 Bh 170-180, P4 Bh-C 270280, P4 Bh 370-380, P4 Bh 380-390. 
A nomenclatura das amostras foi padronizada da seguinte maneira: perfil do Espodossolo (P1 ou P2 ou P3 ou P4), em seguida o tipo de horizonte (A ou E ou AE ou Bh ou Bh-C ou C) e, finalmente, a profundidade de cada horizonte $(0-390 \mathrm{~cm})$.

A determinação do carbono $14 \quad\left({ }^{14} \mathrm{C}\right)$ do solo foi realizado no laboratório de Radiocarbono em Poznań, Poland, como o descrito por Doupoux et al. (2017).

\subsection{Caracterização dos solos e das frações húmicas}

\subsubsection{Análise Elementar}

A determinação de carbono do solo inteiro e das frações húmicas (Ácido Húmico, Ácido Fúlvico e Humina) foram realizadas em duplicata, utilizando-se $3 \mathrm{mg}$ de amostras para os Ácido Húmico e Ácido Fúlvico, e 10mg de amostras para o solo inteiro e Humina. O equipamento empregado foi um analisador elementar da marca Perkin Elmer modelo 2400, pertencente à Embrapa Instrumentação. Para isto as amostras do solo inteiro e humina foram homogeneizadas e passadas em uma peneira de $106 \mathrm{~mm}$ (150 mesh), enquanto que as frações húmicas (AH e AF) foram homogenizadas apenas. Todas as amostras foram pesadas diretamente em cápsulas de estanho, utilizando uma balança analítica e por fim, analisadas por combustão. $\mathrm{O}$ padrão empregado para essa análise foi a acetanilida $(\% \mathrm{C}=71,09 ; \% \mathrm{H}=$ $6,71$ e $\% \mathrm{~N}=10,36)$. A determinação do limite de detecção do equipamento seguiu as recomendações descritas por Miller e Miller (2010), cujos valores calculados nesse estudo foram: $\% \mathrm{C}=0,04 ; \% \mathrm{H}=0,03 ; \% \mathrm{~N}=0,1$.

\subsubsection{Espectroscopia na região do Infravermelho com Transformada de Fourier}

A caracterização por FTIR foi realizada conforme a metodologia adaptada de Stevenson (1994), utilizando pastilhas de 1mg de amostra (Ácido Húmico ou Ácido Fúlvico ou Humina) para cada $400 \mathrm{mg}$ de brometo de potássio (KBr), obtendo uma proporção 1:4 (amostra/KBr). Os espectros foram obtidos de 4.000 a $450 \mathrm{~cm}^{-1}$, com resolução de $4 \mathrm{~cm}^{-1}$ e 32 varreduras. As análises foram realizadas em um Espectrômetro da Bruker modelo Vertex 70 FT-IR Spectrometer acoplado ao modulo RAM II FT-Raman, pertencente a Embrapa Instrumentação - São Carlos.

Uma caracterização dos ácidos húmicos foi realizado empregando um espectrômetro da Thermo Scientific modelo Nicolet iS 50 FT-IR Spectrometer, pertencente a Université de Toulon, França. Para isto, adicionou-se em torno de $1 \mathrm{~g}$ de ácido húmico puro no "porta amostra" do equipamento e em seguida, mediu-se nas condições de 4.000 a $450 \mathrm{~cm}^{-1}$, com 
resolução de $4 \mathrm{~cm}^{-1}$ e 32 varreduras.

\subsubsection{Espectroscopia de Absorção e de Fluorescência de Luz UV-Visível}

Primeiramente, antes de utilizar Espectroscopia de Absorção e de Fluorescência de luz UVVisível, foram realizados testes de concentrações com as amostras de Ácido Húmico e Ácido Fúlvico, a fim de evitar o efeito de filtro interno (Guo et al. 2015). As amostras de ácido húmico e ácido fúlvico foram dissolvidos em uma solução de bicarbonato de sódio $\left(\mathrm{NaHCO}_{3}\right)$ $0,05 \mathrm{~mol} \mathrm{~L}^{-1}$ obtendo-se uma solução com concentração de $12,5 \mathrm{mg} \mathrm{L}^{-1}(\mathrm{pH}=8)$. As medidas foram realizadas empregando Espectrômetro de Luminescência, modelo LS50B da Perkin Elmer. A determinação do índice de humificação das amostras de ácido húmico e ácido fúlvico foi determinada seguindo as metodologias propostas pelos autores: Kalbitz et al. (1999) e Milori et al. (2002).

A metodologia proposta por Kalbitz et al. (1999), mediu-se espectros de varredura na modalidade sincronizada entre 300 a $520 \mathrm{~nm}$ com excitação e emissão com filtro aberto e tendo como diferença de constante de comprimento de onda de $55 \mathrm{~nm}$. O índice de humificação para essa metodologia foi determinado pela razão entre as intensidades de fluorescência em $450 \mathrm{~nm}$ e $370 \mathrm{~nm}\left(\mathrm{I}_{450 \mathrm{~nm}} / \mathrm{I}_{370 \mathrm{~nm}}\right)$, respectivamente. Já na metodologia proposta por Milori et al. (2002) foi obtido espectro de emissão com excitação em 465 nm com varredura de 480 a $700 \mathrm{~nm}$ com filtro aberto, cujo o índice de humificação é baseado na área sob a curva de emissão com excitação em 465 nm $\left(\mathrm{A}_{465 \mathrm{~nm}}\right)$.

Para as análises na modalidade matriz excitação-emissão (EEM) foram empregadas soluções diluídas de ácido húmico e ácido fúlvico, obtendo uma concentração de final da solução de $3 \mathrm{mg} \mathrm{L}^{-1}$ e $2 \mathrm{mg} \mathrm{L}^{-1}$. Assim, os espectros de fluorescência EEM foram adquiridos no intervalo de varredura entre 240-700 nm para emissão e 220-510 nm para excitação. Foram obtidos com filtro de $290 \mathrm{~nm}$ com um incremento de $10 \mathrm{~nm}$ de excitação totalizando 30 varreduras. Os espectros obtidos foram tratados usando método estatístico denominado Análise de Fatores Paralelos (CP/PARAFAC).

\subsubsection{Fluorescência de Supressão (Análise de Quenching)}

\subsubsection{Preparo das amostras}

Os estudos da capacidade de complexação dos Ácidos Húmicos e Ácidos Fúlvicos com os íons $\mathrm{Cu}$ (II) e $\mathrm{Al}$ (III) foram preparados em dezesseis cubetas seguindo o esquema apresentado na Tabela 4.4. As concentrações de Ácido Húmico e Ácido Fúlvico utilizados 
para os estudos envolvendo os íons $\mathrm{Cu}$ (II) e $\mathrm{Al}$ (III) foi de $8,0 \mathrm{mg} \mathrm{L}^{-1}$ de $\mathrm{AH}$ ou AF. A solução de Acetato de Sódio $\left(0,001 \mathrm{~mol} \mathrm{~L}^{-1}\right)$ foi utilizada como solução tampão para o estudo, cujo $\mathrm{pH}$ variou de 5,0 a 6,0. As soluções de metal empregada nesse estudo foram: $\mathrm{CuSO}_{4} \cdot 5 \mathrm{H}_{2} \mathrm{O}\left(0,01 \mathrm{~mol} \mathrm{~L}^{-1}\right)$ e $\mathrm{Al}_{2}\left(\mathrm{SO}_{3}\right) \cdot 18 \mathrm{H}_{2} \mathrm{O}\left(0,01 \mathrm{~mol} \mathrm{~L}^{-1}\right)$, e as concentrações do metal adicionados às soluções variam de: 0 a $105,9 \mathrm{mg} \mathrm{L}^{-1}$ para os íons $\mathrm{Cu}$ (II) e $\mathrm{Al}$ (III). A constante de estabilidade foi determinada de acordo com o procedimento proposto por Ryan e Weber (1982), por meio da supressão de intensidade de fluorescência das amostras.

Tabela 4.4: Esquema do procedimento de preparação das amostras para análise de quenching.

\begin{tabular}{c|c|c|c|c|c|c|c}
\hline CUBETAS & $\begin{array}{c}\text { Volume } \\
\text { amostra } \\
(\boldsymbol{\mu L})\end{array}$ & $\begin{array}{c}\text { Volume } \\
\text { Tampão } \\
(\boldsymbol{\mu L})\end{array}$ & $\begin{array}{c}\text { Volume } \\
\text { Solução } \\
\mathbf{M e t a l ~ 1 ~} \\
(\boldsymbol{\mu L}) *\end{array}$ & $\begin{array}{c}\text { Volume } \\
\text { Solução } \\
\text { Metal 2 } \\
(\boldsymbol{\mu L}) * *\end{array}$ & $\begin{array}{c}\text { Volume } \\
\text { Solução } \\
\text { Metal 3 } \\
(\boldsymbol{\mu L})^{* * *}\end{array}$ & $\begin{array}{c}\text { Volume } \\
\text { água }(\boldsymbol{\mu L})\end{array}$ & $\begin{array}{c}\text { Concentração } \\
\text { final da solução } \\
(\mathbf{m g} / \mathbf{L})\end{array}$ \\
\hline Branco & 480 & 1000 & 0 & 0 & 0 & 1520 & - \\
Amostra 1 & 480 & 1000 & 25 & 0 & 0 & 1495 & 0,00026 \\
Amostra 2 & 480 & 1000 & 50 & 0 & 0 & 1470 & 0,00053 \\
Amostra 3 & 480 & 1000 & 100 & 0 & 0 & 1420 & 0,00106 \\
Amostra 4 & 480 & 1000 & 250 & 0 & 0 & 1270 & 0,00265 \\
Amostra 5 & 480 & 1000 & 500 & 0 & 0 & 1020 & 0,00530 \\
Amostra 6 & 480 & 1000 & 0 & 25 & 0 & 1495 & 0,02648 \\
Amostra 7 & 480 & 1000 & 0 & 50 & 0 & 1470 & 0,05296 \\
Amostra 8 & 480 & 1000 & 0 & 100 & 0 & 1420 & 0,10591 \\
Amostra 9 & 480 & 1000 & 0 & 250 & 0 & 1270 & 0,26478 \\
Amostra 10 & 480 & 1000 & 0 & 500 & 0 & 1020 & 0,52955 \\
Amostra 11 & 480 & 1000 & 0 & 1000 & 0 & 520 & 1,05910 \\
Amostra 12 & 480 & 1000 & 0 & 0 & 100 & 1420 & 10,59100 \\
Amostra 13 & 480 & 1000 & 0 & 0 & 200 & 1320 & 21,18200 \\
Amostra 14 & 480 & 1000 & 0 & 0 & 600 & 920 & 63,54600 \\
Amostra 15 & 480 & 1000 & 0 & 0 & 1000 & 520 & 105,91000 \\
\hline
\end{tabular}

*Solução Metal 1 (Concentração de $\left.5 \times 10^{-6} \mathrm{~mol} \mathrm{~L}^{-1}\right)$;**Solução Metal 2 (Concentração de $\left.5 \times 10^{-5} \mathrm{~mol} L^{-1}\right)$; ***Solução Metal 3 (Concentração de $5 \times 10^{-3} \mathrm{~mol} \mathrm{~L}^{-1}$ )

Fonte: Autoria própria.

\subsubsection{Fluorescência na modalidade $2 \mathrm{D}$}

As medidas de fluorescência foram realizadas empregando Espectrômetro de Luminescência, modelo F4500 da Hitachi. Os espectros de emissão de fluorescência, foram obtidos empregando as metodologias propostas por Mouiner et al. (1999) e Milori et al. (2002). Os espectros foram obtidos realizando excitação em $350 \mathrm{~nm}$ e varredura de 360 a 700 nm de emissão; e com excitação em 465 nm e varredura de 480 a 700 nm de emissão, ambos os métodos foram realizados com incremento de onda de $1 \mathrm{~nm}$ e filtro aberto. 


\subsubsection{Fluorescência na modalidade 3D}

As análises EEM, os espectros de fluorescência foram adquiridos no intervalo de varredura entre $240-700 \mathrm{~nm}$ para emissão e 220-510 nm para excitação. Foram obtidos com filtro aberto e com um incremento de $10 \mathrm{~nm}$ de excitação totalizando 30 varreduras. Os espectros obtidos foram tratados usando CP/PARAFAC.

\subsubsection{Espectroscopia de Fluorescência Resolvida no Tempo}

Para o estudo da Fluorescência Resolvida no Tempo (FRT), foram selecionadas algumas amostras para a análise, a partir dos dados obtidos na Fluorescência de Supressão. Para a preparação da amostra, foram adicionados a cubeta de quartzo, $480 \mu \mathrm{L}$ de uma Solução de $8 \mathrm{mg} \mathrm{L}^{-1}$ de Ácido Húmico extraído do Espodossolo Amazônico, $1.000 \mu \mathrm{L}$ de Solução Tampão de Acetato de Sódio $\left(0,001 \mathrm{~mol} \mathrm{~L}^{-1}\right)$ e completou-se o volume final para $3.300 \mu \mathrm{L}$ com água deionizada. A solução da amostra preparada foi deixada por 10 minutos sob atmosfera de nitrogênio gasoso para eliminar o $\mathrm{O}_{2}$ que induz fotodegradação, e em seguida, realizou-se a medida empregando um Quantaurus-Tau (Hamamatsu). Os espectros de fluorescência resolvida no tempo foram adquiridos no intervalo de varredura entre 300-700 nm para emissão e com excitação em $280 \mathrm{~nm}$. O mesmo estudo foi realizado com as amostras de ácido fúlvico extraídos dos Espodossolos Amazônicos.

\subsubsection{Espectroscopia de Fluorescência Induzida por Laser}

Os espectros LIFS foram registados em pastilhas, contendo $0,5 \mathrm{~g}$ de amostra de solo seco ou de humina, mediante a aplicação de um laser de onda contínua em $405 \mathrm{~nm}$, com potência de $20 \mathrm{~mW}$ e resolução de $10 \mathrm{~nm}$, utilizando um equipamento portátil (Santos et al. 2015). O feixe de laser foi dirigido sobre a superfície da pastilha por meio de seis fibras ópticas externas, e a emissão de fluorescência resultante da decomposição de espécies excitadas foi transferido para o espectrômetro através de um feixe de fibras ópticas central. $\mathrm{O}$ comprimento de onda usado variou de $420 \mathrm{~nm}$ a $800 \mathrm{~nm}$, a intensidade máxima de emissão foi de 1000 counts, e o tempo de integração, média e boxcar selecionados, foram de $400 \mathrm{~ms}, 3$ e 3, respectivamente, para todas as medições. Quatro repetições foram registrados para cada amostra, e utilizou-se o espectro médio na apresentação dos dados. Os valores do índice de humificação $\left(\mathrm{H}_{\mathrm{LIFS}}\right)$ foram determinados seguindo as descrições proposta por Milori e colaboradores (2006), conforme apresentado na equação (1): 


$$
\mathrm{H}_{\mathrm{FIL}}=\frac{\mathrm{ACF}}{\mathrm{COT}}
$$

Equação (1)

Onde, ACF: área do espectro de emissão em 405 nm com excitação de 420-800 nm e COT: quantidade de carbono presente na amostra.

\subsubsection{Espectrometria de Absorção Atômica com Atomização por Chama (FAAS) ou Forno de Grafite (GFAAS)}

Primeiramente para a análise dos solos inteiros empregando a Espectrometria de Absorção Atômica com Atomização por Chama ou Forno de Grafite, fez-se necessário realizar uma decomposição química nos quatros Espodossolos preconizados nesse estudo.

A decomposição das amostras dos solos seguiram as recomendações descritas no Método 3052 da EPA (1996), empregou-se um Espectrômetro de Absorção Atômica com Atomização por Chama (FAAS) e/ou Forno de Grafite (GFAAS), modelo PinAAcle 900T, marca PerkinElmer para determinação dos seguintes elementos químicos: Potássio (K), Ferro $(\mathrm{Fe})$, Cálcio $(\mathrm{Ca})$, Magnésio $(\mathrm{Mg})$, Zinco ( $\mathrm{Zn})$, Alumínio (Al), Manganês (Mn), Cobre $(\mathrm{Cu})$, Crômio (Cr), Cádmio (Cd) e Cobalto (Co).

Para as amostras de ácido húmico, ácido fúlvico e humina empregou-se a mesma metodologia e os elementos químicos quantificados foram: Potássio (K), Ferro ( $\mathrm{Fe}$ ), Magnésio (Mg), Zinco (Zn) e Alumínio (Al). As amostras selecionadas para esse estudo foram dos Espodossolos dos P1 e P4, sendo um Espodossolo hidromórfico e outro Espodossolo bem drenado, respectivamente.

\subsubsection{Espectroscopia de Emissão Óptica com Plasma Induzido por Laser}

Os espectros LIBS foram obtidos utilizando um modelo de LIBS comercial sistema 2500 (Ocean Optics, EUA). Este sistema inclui sete espectrômetros que são capazes de produzir uma resolução de 0,1 nm (FWHM) para análise espectral na gama 188-980 nm, um laser de Nd comutação-Q: YAG operando a 1.064 nm, uma câmara de ablação, uma lente de focalização do laser, e um sistema óptico para recolher a emissão de plasma e enviá-lo para os espectrômetros. Um pulso de laser de $50 \mathrm{~mJ}$ da energia para uma duração de $8 \mathrm{~ns}$ foi usado para todas as medições. O laser tinha uma fluência de cerca de $1,2 \times 103 \mathrm{~J} \mathrm{~cm}^{-2}$. O tempo de atraso e o tempo de integração usado eram $6 \mathrm{~ms}$ e $2 \mathrm{~ms}$, respectivamente, que são fixos condições instrumentais.

A distância entre a lente da radiação e a amostragem do plasma era aproximadamente $1 \mathrm{~cm}$. Para cada amostra, 30 medições foram feitas em diferentes posições da pastilha de 
amostra de solo e frações húmicas, e cada medição corresponde a dois disparos de laser, o que gerou um espectro médio. Antes da análise, um tiro de laser também foi usado para limpar a superfície da amostra. O deslocamento dos espectros LIBS foi corrigido subtraindo a média da região ruído aleatório perto da linha de emissão elemento, o que está diretamente relacionado com a sua concentração, no qual foi calculado a sua área, utilizando um ajuste de Lorentz.

\subsubsection{Ressonância Magnética Nuclear}

A Caracterização por Espectroscopia de Ressonância Magnética Nuclear de Alto Campo foi realizada empregando um Avance III HD / Bruker $400 \mathrm{MHz}$. Os espectros de RMN foram obtidos aplicando uma frequência de rotação do rotor de $10 \mathrm{KHz}$, com tempo de aquisição de 30 milisegundos e 256-512 varreduras para análise do Carbono 13. As amostras de AH foram medidas em rotores cilíndricos de zircône com diâmetro de 4,0 mm carregados com 100-200 mg da amostra. Os deslocamentos químicos foram expressos em PPM, sendo utilizado como referência externa o hexametilbenzeno (HMB), cujo sinal do grupo metila foi referenciado em $17,3 \mathrm{ppm}$.

A partir dos espectros obtidos, determinou-se a porcentagem de aromaticidade e alifaticidade seguindo as descritos proposta por Stevenson (1994):

$$
\begin{aligned}
& \text { Aromaticidade }(\%)=\frac{\text { Area dos sinais de Carbono aromático de } 110-160 \mathrm{ppm}}{\text { Area dos sinais de Carbono de } 0-160 \mathrm{ppm}} \times 100 \\
& \text { Alifaticidade }(\%)=\frac{\text { Area dos sinais de Carbono Alifáticos de } 0-110 \mathrm{ppm}}{\text { Area dos sinais de Carbono de } 0-160 \mathrm{ppm}} \times 100
\end{aligned}
$$


Capítulo 5 - Resultados e Discussão 


\section{$\underline{\text { Parte I - Estudo da matéria }}$ orgânica do solo}




\section{I.1. Análise elementar}

As quantidades de Carbono obtido pela Análise Elementar dos Espodossolos Amazônico estão apresentadas na Tabela 5.I.5.

Tabela 5.I.5: Valores de Carbono (\%), Nitrogênio (\%) e Hidrogênio (\%) dos Espodossolos Amazônicos.

\begin{tabular}{|c|c|c|c|}
\hline Amostras & \% Carbono & \% Hidrogênio & \% Nitrogênio \\
\hline P1 A $0-15$ & $22,5 \pm 0,9$ & $2,0 \pm 0,1$ & $1,02 \pm 0,06$ \\
\hline P1 A $15-30$ & $1,01 \pm 0,09$ & $0,04 \pm 0,01$ & $*$ \\
\hline $\mathrm{P} 1 \mathrm{Bh} 40-50$ & $2,1 \pm 0,2$ & $0,12 \pm 0,01$ & $*$ \\
\hline P1 Bh-C 240 & $3,2 \pm 0,2$ & $1,05 \pm 0,07$ & $0,10 \pm 0,01$ \\
\hline P1 Bh-C 260 & $0,80 \pm 0,03$ & $0,23 \pm 0,02$ & $*$ \\
\hline P1 C 350 & $1,2 \pm 0,2$ & $0,22 \pm 0,02$ & $*$ \\
\hline P2 A $0-15$ & $3,0 \pm 0,2$ & $0,23 \pm 0,02$ & $0,20 \pm 0,02$ \\
\hline P2 A-E $15-30$ & $1,6 \pm 0,1$ & $0,07 \pm 0,01$ & $*$ \\
\hline P2 Bh 290 & $18,2 \pm 0,5$ & $1,42 \pm 0,05$ & $0,35 \pm 0,02$ \\
\hline P3 A $0-15$ & $2,3 \pm 0,1$ & $0,16 \pm 0,01$ & $0,12 \pm 0,02$ \\
\hline P3 Bh 165-175 & $5,0 \pm 0,1$ & $0,58 \pm 0,02$ & $0,15 \pm 0,01$ \\
\hline P3 Bh 180-183 & $4,56 \pm 0,04$ & $0,70 \pm 0,03$ & $0,19 \pm 0,05$ \\
\hline P3 Bh 210 & $3,6 \pm 0,3$ & $0,76 \pm 0,08$ & $0,11 \pm 0,01$ \\
\hline P3 Bh 280-310 & $9,7 \pm 0,4$ & $1,02 \pm 0,06$ & $0,27 \pm 0,02$ \\
\hline P3 Bh 335-350 & $6,3 \pm 0,6$ & $0,86 \pm 0,02$ & $0,17 \pm 0,03$ \\
\hline P4 A 0-20 & $3,9 \pm 0,2$ & $0,35 \pm 0,01$ & $0,23 \pm 0,01$ \\
\hline P4 A $20-30$ & $3,5 \pm 0,2$ & $0,38 \pm 0,04$ & $0,27 \pm 0,02$ \\
\hline P4 A $30-40$ & $0,89 \pm 0,01$ & $0,07 \pm 0,02$ & $0,11 \pm 0,04$ \\
\hline P4 Bh 110-120 & $0,42 \pm 0,02$ & $0,04 \pm 0,01$ & $*$ \\
\hline P4 Bh 170-180 & $0,38 \pm 0,01$ & $*$ & $*$ \\
\hline P4 Bh-C 270-280 & $0,25 \pm 0,01$ & $*$ & $*$ \\
\hline P4 Bh 370-380 & $0,48 \pm 0,01$ & $0,05 \pm 0,02$ & $*$ \\
\hline P4 Bh 380-390 & $0,78 \pm 0,01$ & $0,10 \pm 0,02$ & $*$ \\
\hline
\end{tabular}

$*$ Valores abaixo do limite de detecção do equipamento $(\% \mathrm{C}=0,04 ; \% \mathrm{H}=0,03 ; \% \mathrm{~N}=0,1)$.

Fonte: Autoria própria

Os resultados mostraram que a alta quantidade de carbono presente na matéria orgânica do solo foi observada no horizonte A dos Espodossolo permanentemente alagado (P1) e no Espodossolo bem drenado (P4), representados pelos pontos: P1 A 0-15 e P4 A 0-20, respectivamente. Nos Espodossolo sazonalmente alagado, os P2 e P3, os maiores valores de carbono obtidos foi nos horizontes Bh, sendo P2 Bh 290 e P3 Bh 280-310, respectivamente. Destacando-se o horizonte do P2 Bh 290, que obteve um valor de carbono de 18,2 \pm 0,5. Segundo Montes et al. (2011), os Espodossolos Amazônico mal drenados podem ter horizontes Bh com espessura superior a 1 metro e armazenar quantidades inesperadas de 
carbono nesses horizontes. Enquanto que os valores de hidrogênio e nitrogênio não conferiram variações significativas com o decorrer da profundidade, os quais variaram de 2,00 a $0,04 \%$ e 1,02 a $0,1 \%$, respectivamente, para todos os solos estudados. Um fator interessante verificado na Tabela 5.I.5, foi que quando há um acumulo de carbono nos horizontes $\mathrm{Bh}$ mais profundos observou-se um aumento na quantidade de hidrogênio para o mesmo horizonte. Este comportamento pode estar associado à incorpoação de estrutura mais simples com cadeias alifáticas e/ou estruturas mais instáveis da MOS, o que irá refletir em uma humificação menor em alguns desses horizontes, conforme será abordado a seguir.

\section{I.2. Espectroscopia de Fluorescência Induzida por Laser}

O LIFS foi aplicado nas amostras de solos inteiro e os espectros obtidos estão exibidos na Figura 5.I.11.

Figura 5.I.11: Espectro de Emissão em $405 \mathrm{~nm}$ obtido pelo LIFS para os vários horizontes das amostras dos Espodossolos: P1 (a), P2 (b), P3 (c) e P4 (d). Observação nos P1, P2 e P3 a maioria dos seus horizontes estão em condições hidromórfica, ou seja, sob influência do lençol freático.
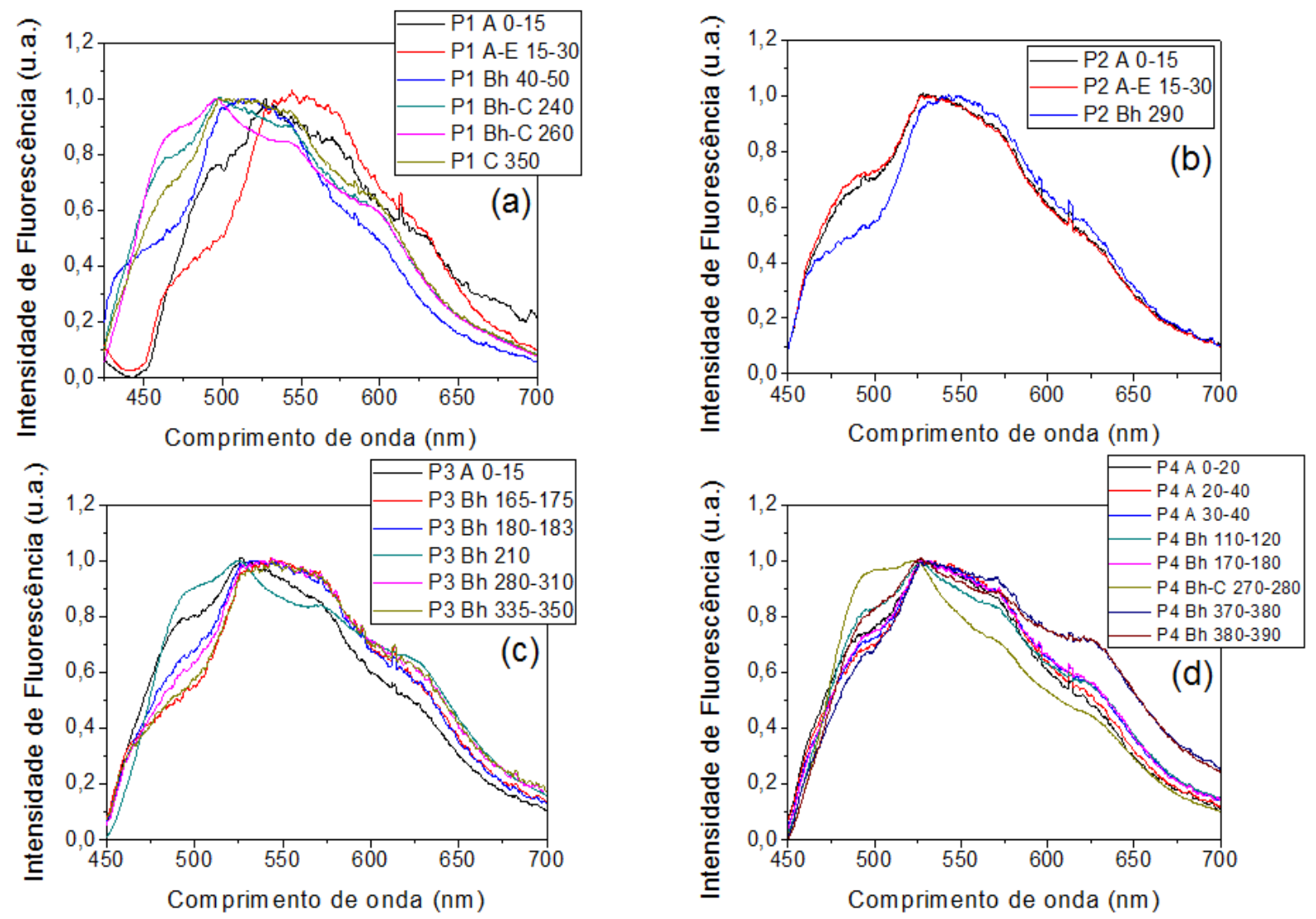

Fonte: Autoria própria.

Os espectros de emissão dos quatros Espodossolos mostram uma banda larga com uma 
intensidade máxima de 525-550 nm, com ombros de ambos os lados, e são semelhantes aos relatados na literatura para MOS (Senesi et al., 1991; Milori et al., 2002; Tivet et al., 2013; Santos et al., 2015) conforme observado na Figura 5.I.11. Essa região de comprimentos de onda de 525-550 $\mathrm{nm}$ sugere a presença relevante de componentes moleculares caracterizados por uma estrutura aromática resistente de policondensado com um elevado grau de conjugação e podem transportar substituintes, como grupos carbonilas e carboxílicos.

Com o aumento da profundidade do solo para os P1, P3 e P4, foi possível verificar o aparecimento de uma banda de intensidade em $475 \mathrm{~nm}$, o que corresponde a uma excitação na região do azul. No P2, esse pico apareceu nos horizontes superficiais $(0-30 \mathrm{~cm})$. Essa região favorece excitação de grupos com estrutura mais simples, como cadeias alifáticas e compostos mais simples (Senesi et al., 1991; Tivet et al., 2013). Na Figura 5.I.11, pode-se também observar o aparecimento de uma banda entorno de $625 \mathrm{~nm}$, principalmente para os horizontes mais profundos dos P3 e P4, o que representa uma excitação na região do vermelho, o que favorece a emissão de grupos mais condensados, como grupos de carbono contendo anéis aromáticos na sua estrutura.

Os valores do índice de humificação $\left(\mathrm{H}_{\mathrm{LIFS}}\right)$ foram calculados a partir de espectros LIFS (Figura 5.I.11) conforme proposto por Milori et al. (2002). A partir do cálculo desse índice de humificação (item 4.5.6 da parte experimental, página 58), nós propusemos que as amostras escuras possam apresentar auto-absorção de fluorescência, pois se observou que quanto mais escuras eram as amostras menores foram os valores de $\mathrm{H}_{\text {LIFS }}$ obtidos. Assim, aplicamos uma correção na emissão de fluorescência obtida pelo LIFS por um fator que leva em conta esse fenômeno. $\mathrm{O}$ índice $\mathrm{H}_{\mathrm{LIFS}}$ foi dividido pelo valor da cor da amostra presente na Carta Munsell (Munsell, 2000): quanto mais escura a amostra, menor o valor. Assim, encontramos $\mathrm{H}_{\text {LIFS_M }}$, que trata do índice corrigido (Tabela 5.I.6). Esse estudo foi apresentado no artigo publicado à Science of the Total Environment (STOTEN) em junho e encontra-se em análise (Anexo F, página 168).

As amostras dos horizontes Bh, abaixo de 240 e $210 \mathrm{~cm}$ dos solos P1 e P4, respectivamente, apresentam índices de humificação mais elevados em comparação com os horizontes de superfície e, P2 e P3. Esse comportamento pode ser associado à percolação da matéria orgânica mais humificada que se deposita em esses horizontes. No solo P4, o índice de humificação mais elevado (HLIF__M $)$ estava no perfil profundo, como P4 Bh-C 270-280. No horizonte abaixo, P4 Bh 370-380, observou-se uma acumulação de carbono, mas com baixa humificação, que pode estar relacionada a uma baixa quantidade de carbono aromático condensado neste horizonte. 
Nos perfis de solos P1 e P4, pode-se observar que há uma variação dos índices de humificação (HIF__M $)$ em profundidade crescente, enquanto que não foi observado para os solos P2 e P3, cujos valores apresentaram pouca variação $\left(\mathrm{H}_{\text {LIFS_M }}\right.$ foi 0,2 a $6 \times 10^{3}$ ). Esses resultados corroboram estudos descritos por González-Pérez et al. (2007) que mostraram que a acumulação de mais aromáticos e humificados conjugados da MOS ocorre nos horizontes mais profundos dos solos sob plantio direto e vegetação nativa, enquanto que a humificação da MOS é menor nos horizontes superficiais. De acordo com Bardy et al. (2008), o caráter aromático observado nos horizontes Bh do Podzol Amazônico pode ser adquirido durante o processo de humificação e/ou percolação deste material húmico aromático. Este material, de baixo peso molecular e maior solubilidade, migrará e se acumulará em horizontes que podem ser mais macroporosos. Assim, sugerindo que este processo pode estar ocorrendo nos horizontes Bh profundo desses solos, P1 e P4.

Tabela 5.I.6: Datação de carbono, valores de cor da Carta Munsell, $\mathrm{H}_{\text {LIFS }}$ e $\mathrm{H}_{\mathrm{LIFS} \_\mathrm{M}}$ dos horizontes do solo.

\begin{tabular}{|c|c|c|c|}
\hline \multirow{2}{*}{$\begin{array}{l}\text { Descrição das } \\
\text { amostras }\end{array}$} & \multicolumn{3}{|c|}{ Solo } \\
\hline & Datação do solo (anos) & Cor Munsell & H $_{\text {LIFS_M }}\left(\mathbf{x 1 0 ^ { 3 }}\right)$ \\
\hline P1 A $0-15$ & $*$ & 10YR3/2 & $0,2 \pm 0,1$ \\
\hline P1 A-E 15-30 & $2.645 \pm 30$ & $10 \mathrm{YR} 4 / 3$ & $2 \pm 1$ \\
\hline $\mathrm{P} 1 \mathrm{Bh} 40-50$ & $3.240 \pm 35$ & $10 \mathrm{YR} 3 / 2$ & $4 \pm 1$ \\
\hline P1 Bh-C 240 & $*$ & 7,5YR4/4 & $22 \pm 5$ \\
\hline P1 Bh-C 260 & * & 7,5YR4/4 & $17 \pm 2$ \\
\hline $\mathrm{P} 1 \mathrm{C} 350$ & $*$ & $2,5 \mathrm{Y} 4 / 3$ & $15 \pm 2$ \\
\hline P2 A $0-15$ & $105 \pm 1$ & 10YR4/1 & $3 \pm 2$ \\
\hline P2 A-E $15-30$ & $50 \pm 30$ & 10YR5/1 & $4 \pm 1$ \\
\hline $\mathrm{P} 2 \mathrm{Bh} 290$ & $*$ & $5 \mathrm{YR} 2.5 / 2$ & $0,2 \pm 0,1$ \\
\hline P3 A $0-15$ & $106 \pm 1$ & 7,5YR3/2 & $2,8 \pm 0,4$ \\
\hline P3 Bh 165-175 & $5.060 \pm 30$ & 7,5YR2/1 & $3 \pm 1$ \\
\hline P3 Bh 180-183 & $5.860 \pm 35$ & $7,5 \mathrm{YR} 3 / 3$ & $1,3 \pm 0,2$ \\
\hline P3 Bh 210 & $8.480 \pm 40$ & $10 Y R 5 / 4$ & $6 \pm 4$ \\
\hline P3 Bh 280-310 & $6.165 \pm 35$ & $5 Y R 2.5 / 1$ & $5 \pm 1$ \\
\hline $\mathrm{P} 3 \mathrm{Bh} 335-350$ & $5.590 \pm 40$ & $5 Y R 2.5 / 1$ & $4 \pm 1$ \\
\hline P4 A $0-20$ & $107 \pm 1$ & $10 \mathrm{YR} 4 / 2$ & $2,7 \pm 0,2$ \\
\hline P4 A 20-30 & $105 \pm 1$ & $10 \mathrm{YR} 2 / 2$ & $10 \pm 2$ \\
\hline P4 A $30-40$ & $460 \pm 30$ & $10 \mathrm{YR} 2 / 2$ & $11 \pm 2$ \\
\hline P4 Bh $110-120$ & $2.510 \pm 30$ & $10 \mathrm{YR} 4 / 2$ & $24 \pm 3$ \\
\hline P4 Bh 170-180 & $7.570 \pm 50$ & $10 \mathrm{YR} 2 / 2$ & $23 \pm 2$ \\
\hline P4 Bh-C 270-280 & $*$ & 2,5YR6/4 & $132 \pm 44$ \\
\hline P4 Bh 370-380 & $9.980 \pm 60$ & $10 \mathrm{YR} 2 / 2$ & $20 \pm 1$ \\
\hline P4 Bh 380-390 & $*$ & 7,5YR3/3 & $37 \pm 4$ \\
\hline
\end{tabular}

*Amostras não analisada.

Fonte: Autoria própria. 
Os maiores valores do $\mathrm{H}_{\text {LIFS_M }}$ nesses solos (P1 e P4) foram observados para o horizonte Bh, dos solos P1 Bh-C 240, P1 Bh-C 260 e P4 Bh-C 270-280, sendo o maior valor obtido para o solo do P4 (Espodossolo bem drenado). Aparentemente, a MOS infiltra para baixo do perfil do P4, e em seguida, se acumula sob a forma mais humificada persistindo no horizonte Bh mais profundo (P4 Bh 270-280).

Nos Espodossolos sazonalmente alagados dos P2 e P3, em particular, o maior valor de

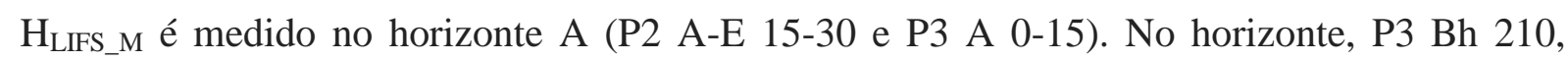
verifica-se um acumulo de carbono e uma humificação relativamente alta (Tabela 5.I.6). Sendo assim, a quantidade de carbono e o índice de humificação podem estar sendo afetados pelo nível do lençol freático, principalmente nos solos Espodossolos dos P1, P2 e P3 que sofrem ação diretamente do lençol freático suspenso. Além de um movimento vertical descendente da MOS, há um transporte horizontal de Carbono pelo movimento das águas subterrâneas e que ocorre a partir da superfície para os horizontes mais profundos.

Senesi e colaboradores (2016) realizando um estudo crítico do trabalho proposto por Gonzalez-Perez et al. (2007), determinou o índice de humificação dos solos sob diferentes

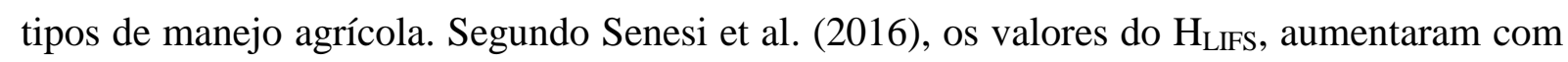
a empregabilidade do solo, ou seja, solos de preparo convencional > solo de plantio direto > solo de vegetação nativa. Esses autores, preconizaram que nos solos sob vegetação nativa, o baixo valor de $\mathrm{H}_{\text {LIFS }}$ pode estar associado à inacessibilidade espacial, em que a matéria orgânica nesse tipo de solo, possui uma proteção física, dando características de agregados ou microagregados mais estáveis a MO mais lábil ao invés de ocorrer uma preservação seletiva e/ou de interação entre MOS-minerais.

Nos Espodossolos hidromórficos P1 a P3, pode-se observar que os valores de HLIFS_M $_{\text {L }}$ aumentaram com a profundidade. Este resultado sugere que a presença de água nesses solos pode provocar uma diminuição na taxa de decomposição da MOS devido à condição anaeróbica do meio. Esta condição favorece o aumento da estabilização da MOS, promovendo a humificação e um aumento dos componentes mais recalcitrantes da matéria orgânica com a profundidade, enquanto que componentes instáveis predominam na camada superficial devido ao aporte constante de resíduos vegetais frescos que a floresta providencia (Senesi et al. 2016).

Zúñiga (2006) empregando as substâncias húmicas aquáticas extraídas do Rio Negro AM mostrou que o mecanismo de produção está diretamente dependente de fatores, tais como temperatura, umidade, precipitações, fluxos de água e disponibilidade de oxigênio, os quais apresentam impacto direto na produção química e microbiana da MO e posteriormente a sua 
liberação por lixiviação e drenagem dos solos circundantes. Segundo esse mesmo autor, o principal mecanismo de ingresso das SH Aquática do rio Negro deve-se à drenagem dos rios de águas pretas, em que a matéria orgânica dissolvida destes rios é de origem terrestre, derivada dos solos das florestas circundantes. Demonstrando assim, uma importante contribuição da percolação e lixiviação dessas MOD presentes nesses solos que são carreadas por meio dos lençóis freáticos até esses rios.

Segundo Von Lutzow e colaboradores (2006) os mecanismos de estabilidade da matéria orgânica no solo dependem: da preservação seletiva do material acumulado, da inacessibilidade espacial dos agregados e das interações da matéria orgânica com a superfície dos minerais, sendo esse último mecanismo verificado nesse estudo. Entre as áreas discutidas neste estudo, os menores valores do índice de humificação foram verificados nos horizontes superficiais, sugerindo que a houve uma decomposição da matéria orgânica mais lábil pela ação de microrganismos (Bayer et al., 2000).

Segundo Senesi e Colaboradores (2016), a estabilização da matéria orgânica do solo deve-se ao processo de humificação. Esse processo além de inserir compostos mais recalcitrantes, incluindo lignina, compostos fenólicos e componentes alifáticos resistentes, pode também incorporar fragmentos moleculares menores provenientes de uma matéria orgânica mais lábil devido à atividade microbiana no meio. Assim, os índices de humificação mais baixos medidos para o MOS nos horizontes de superfície podem ser atribuídos à presença de matéria orgânica mais lábil, isto é, derivados de plantas e/ou compostos nãohúmicos originados pela ação recente de microorganismos, enquanto ocorreria uma decomposição crescente da MOS com aumento da profundidade do solo. Esse aumento está associado ao deslocamento das moléculas mais solúveis e de menor tamanho molecular aos horizontes mais profundos devido aos processos físicos (tamanho) e químicos (afinidade mineral) (Bayer et al., 2000; Senesi et al., 2016).

Foi realizado um estudo de correlação entre o índice de humificação ( HLIFS_M $_{-}$e a datação do carbono $\left({ }^{14} \mathrm{C}\right)$ no solo inteiro das amostras dos Espodossolos P1, P3 e P4. A Figura 5.I.12 mostra os valores HLIFS_M $_{\text {dos }}$ solos em função da datação por radiocarbono dos horizontes dos solos e observaram-se a formação de quatro grupos. Vale ressaltar que o Perfil 2 não foi adicionado nesse estudo devido a pouca quantidade de horizontes analisados. 
Figura 5.I.12: Valores de $\mathrm{H}_{\text {LIFS_M }}$ dos solos em função da datação de carbono dos Espodossolos P1, P3 e P4.

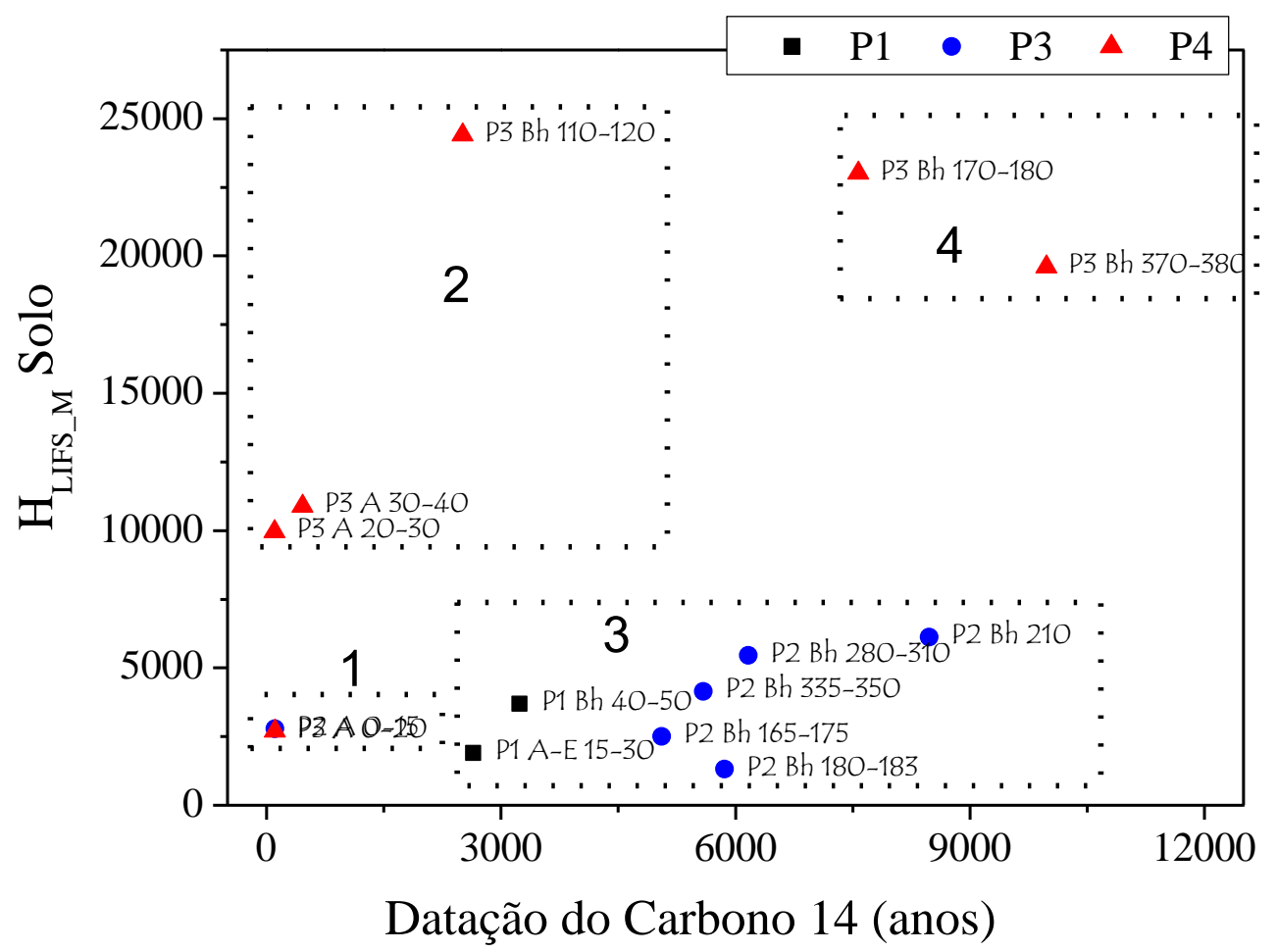

Fonte: Autoria Própria (Artigo Tadini et al. 2017 - Anexo F, página 168).

Na Figura 5.I.12, o primeiro grupo inclui solos de horizontes de superficiais com valores baixos de $\mathrm{H}_{\text {LIFS_M }} \mathrm{e}$ idade de carbono mais recente, isto é, estruturas ricas em compostos lábeis. O segundo grupo de amostras de solos é observado apenas para horizontes de superfície que se referem a uma matéria orgânica jovem, mas com humificação intermediária $\left(\mathrm{H}_{\text {LIFS_M }}\right)$. Este resultado demonstra a rápida contribuição das estruturas de carbono com anéis aromáticos condensados que possivelmente vem da recente atividade microbiana levando a uma matéria orgânica aromática condensada, mas nova. Uma hipótese sugerida é que este material orgânico é originado por vias de formação de polifenóis (condensação de polifenóis) e transformados em quinonas, que reagem com outros compostos (Wu et al., 2017).

O terceiro grupo tem influência direta das águas subterrâneas e inclui o horizonte P1 A-E 15-30 e P1 Bh 40-50 e todos os horizontes Bh da P3. Eles apresentam baixa humificação para o solo $\left(\mathrm{H}_{\text {LIFS_M }}\right)$. No entanto, esse grupo mostra carbono mais antigo do que na superfície, que pode ser associado à presença de poucas modificações estruturais. Uma hipótese é que este grupo apresente compostos ricos em derivados de lignina. O quarto grupo 


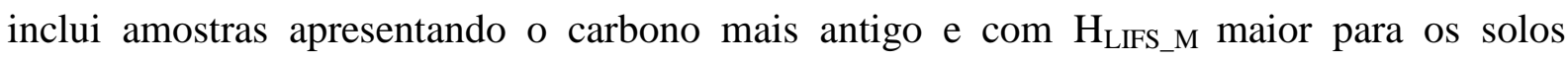
inteiros. Além disso, esses resultados sugerem que o MOS nos horizontes de superfície inclui compostos simples e lábeis e pouco humificado, ao passo que os compostos humificados mais complexos são lixiviados e acumulados ou retidos em horizontes mais profundos enquanto a molécula pequena e menos condensada é direcionada pelo fluxo de água (Lucas et al., 2012). Portanto, existem quatro tipos de matéria orgânica: - uma humificada, recalcitrante e antiga; lábil e jovem; - pouco humificada e antiga; - humificada e jovem. Desta forma, o processo de humificação não tem relação direta com a datação do material orgânico.

\section{I.3. Espectrometria de Absorção Atômica com Atomização por Chama ou Forno Grafite}

A Tabela 5.I.7 apresenta os dados obtidos para os principais elementos encontrados nas amostras dos solos inteiros dos Espodossolos Amazônicos. Na Tabela 5.I.7, apresentou uma variedade de macro e micronutrientes obtidos para os Espodossolos Amazônico. Sendo os maiores valores observados para o Potássio, Ferro e Alumínio, sendo os esses dois últimos os metais atuam diretamente no processo de gênese desse tipo de solo.

Em solos mais arenosos do tipo do Espodossolos, a quantidade de cálcio é baixa conforme observado na Tabela 5.I.7, em que os valores foram abaixo do limite de detecção do equipamento (menor que $0,05 \mathrm{mg} / \mathrm{kg}$ ) e apenas dois horizontes apresentaram valores acima, os quais foram: P1 A 0-15 e P4 A 30-40, em que o P1 pode estar associado a condição aneróbica desse solo (Bispo, 2010), bem como a incorporação de resíduo de plantas decorrente da vegetação florestal no Espodossolo bem drenado (P4) (Salvador et al. 2011).

Em solos alagados, como os Espodossolos hidromórficos P1, P2 e P3, a água substitui os espaços porosos do solo, o que restringe a troca de gases com a atmosfera e a perda de oxigênio pelos organismos, tornando o meio em um ambiente redutor (Bispo, 2010; Sousa et al. 2010). O meio redutor permite a redução de alguns macro e micronutrientes, como o Ferro e Manganês, respectivamente. Os microorganismos anaeróbicos presente nesse sistema podem utilizar receptores de elétrons de origem orgânica para a fermentação dos compostos orgânicos complexos em substâncias mais simples, como ácidos orgânicos, aminas, entre outros (Sousa et al. 2010). Ao observar a Tabela 5.I.7, os valores do Ferro e Manganês para esses solos alagados (P1, P2 e P3), foram maiores nos horizontes que são influenciados diretamente pelo lençol freático suspenso. 
Tabela 5.I.7: Concentrações dos metais Potássio (K), Ferro (Fe), Cálcio (Ca), Magnésio (Mg), Zinco (Zn), Alumínio ( $\mathrm{Al})$, Manganês $(\mathrm{Mn})$, Cobre $(\mathrm{Cu})$, Crômio $(\mathrm{Cr})$ e Cobalto $(\mathrm{Co})$ nas amostras dos Espodossolos Amazônico.

\begin{tabular}{|c|c|c|c|c|c|c|c|c|c|c|c|}
\hline \multirow[b]{2}{*}{ Amostras } & \multicolumn{6}{|c|}{ Concentração de metais em g/kg } & \multicolumn{5}{|c|}{ Concentração de metais em mg/kg } \\
\hline & $\begin{array}{c}\mathbf{K} \\
( \pm \mathbf{0 , 1})\end{array}$ & $\begin{array}{c}\mathbf{F e} \\
( \pm \mathbf{0 , 1})\end{array}$ & $\begin{array}{c}\mathrm{Ca} \\
( \pm \mathbf{0 , 1})\end{array}$ & $\begin{array}{c}\mathrm{Mg} \\
( \pm \mathbf{0 , 0 1})\end{array}$ & $\begin{array}{c}\mathbf{Z n} \\
( \pm \mathbf{0 , 0 1})\end{array}$ & $\begin{array}{c}\text { Al } \\
( \pm 1)\end{array}$ & $\begin{array}{l}\text { Mn } \\
( \pm 1)\end{array}$ & $\begin{array}{c}\text { Cd } \\
( \pm 1)\end{array}$ & $\underset{( \pm \mathbf{0 , 1})}{\mathbf{C u}}$ & $\begin{array}{c}\mathrm{Cr} \\
( \pm 1)\end{array}$ & $\begin{array}{c}\text { Co } \\
( \pm 0,1)\end{array}$ \\
\hline P1 A 0-15 & 3,0 & 1,2 & 0,1 & 0,46 & 0,07 & 43 & 20 & 3 & 5,5 & 8 & 1,7 \\
\hline P1 A 15-30 & 1,9 & 0,9 & * & 0,17 & $*$ & 39 & 22 & 1 & 2,4 & 7 & $*$ \\
\hline P1 Bh 40-50 & 2,1 & 0,8 & $*$ & 0,20 & $*$ & 57 & 16 & 2 & 2,3 & 8 & 0,4 \\
\hline P1 Bh-C 240 & 3,5 & 6,4 & $*$ & 0,22 & 0,07 & 92 & 22 & 3 & 4,1 & 27 & 2,1 \\
\hline P1 Bh-C 260 & 3,0 & 2,1 & $*$ & 0,21 & 0,01 & 71 & 23 & 3 & 2,8 & 13 & 1,6 \\
\hline P1 C 350 & 5,0 & 1,8 & $*$ & 0,20 & 0,05 & 52 & 35 & 2 & 3,9 & 12 & 1,5 \\
\hline P2 A 0-15 & 2,0 & 0,6 & $*$ & 0,13 & $*$ & 31 & 17 & 1 & 2,7 & 5 & 0,4 \\
\hline P2 A-E 15-30 & 2,2 & 0,7 & $*$ & 0,29 & 0,05 & 40 & 22 & 3 & 3,8 & 6 & 0,5 \\
\hline P2 Bh 290 & 1,2 & 0,7 & $*$ & 0,16 & 0,04 & 25 & 29 & 1 & 5,1 & 11 & 0,8 \\
\hline P3 A 0-15 & 2,3 & 0,6 & $*$ & 0,26 & * & 51 & 12 & 1 & 2,5 & 6 & 1,1 \\
\hline P3 Bh 165-175 & 2,6 & 2,9 & $*$ & 0,45 & 0,05 & 60 & 26 & 1 & 4,4 & 12 & 0,9 \\
\hline P3 Bh 180-183 & 2,7 & 4,8 & $*$ & 0,22 & 0,08 & 78 & 27 & 2 & 3,7 & 16 & 1,2 \\
\hline P3 Bh 210 & 4,1 & 5,9 & $*$ & 0,48 & 0,01 & 83 & 30 & 2 & 6,0 & 25 & 1,9 \\
\hline P3 Bh 280-310 & 4,4 & 2,4 & $*$ & 0,23 & 0,01 & 68 & 29 & 4 & 7,3 & 17 & 1,8 \\
\hline P3 Bh 335-350 & 3,7 & 3,6 & $*$ & 0,19 & 0,05 & 48 & 27 & 3 & 4,8 & 16 & 1,7 \\
\hline P4 A 0-20 & 3,6 & 1,0 & $*$ & 0,22 & 0,08 & 48 & 15 & 1 & 3,2 & 7 & 0,6 \\
\hline P4 A 20-30 & $*$ & 0,4 & $*$ & 0,03 & $*$ & 13 & 5 & 1 & 2,3 & 3 & $*$ \\
\hline P4 A 30-40 & 5,8 & 1,8 & 0,2 & 0,46 & 0,02 & 46 & 20 & 2 & 3,8 & 10 & 1,5 \\
\hline P4 Bh 110-120 & $*$ & 0,1 & $*$ & 0,03 & * & 11 & 5 & 2 & 2,9 & 3 & 0,3 \\
\hline P4 Bh 170-180 & 3,9 & 1,2 & $*$ & 0,20 & 0,03 & 49 & 13 & 2 & 2,8 & 7 & 0,9 \\
\hline P4 Bh-C 270-280 & 6,3 & 2,0 & $*$ & 0,54 & 0,03 & 51 & 22 & 3 & 4,4 & 11 & 1,0 \\
\hline P4 Bh 370-380 & 4,5 & 0,9 & $*$ & 0,27 & 0,07 & 41 & 16 & 1 & 4,6 & 8 & 0,8 \\
\hline P4 Bh 380-390 & $*$ & 0,2 & $*$ & $*$ & $*$ & 15 & 6 & 1 & 3,1 & 6 & 0,9 \\
\hline
\end{tabular}

*Abaixo do limite de detecção do equipamento $(0,05 \mathrm{mg} / \mathrm{Kg})$.

Fonte: Autoria própria.

Os valores do metal aluminio foram maiores que os valores do metal ferro para os quatros Espodossolos, sugerindo assim, uma maior participação das espécies de alumínio no processo de Podzolização (Santos, 2014). Uma tendência de aumento desses metais foi verificado nos horizontes subsuperficiais (A e A-E) até os horizontes Bh mais profundos, sendo que os maiores valores foram: P1 Bh-C 240; P2 A-E 15-30; P3 Bh 210 e P4 Bh-C 270280. Destaca-se ainda, que os horizontes mencionados anteriormente foram os que obtiveram 
os maiores índice de humificação, conforme apresentado na Tabela 5.I.6. Assim, sugerindo que o acúmulo dos metais nesses solos, deve-se a interação e a formação de complexos estáveis com a matéria orgânica nesses horizontes. Além disso, a condição anaeróbica, não favorece o acúmulo do $\mathrm{Fe}^{3+}$ nos horizontes mais profundos, uma vez que esse metal esteja se perdendo por reação de redução de óxidos férricos.

Os resultados obtidos nesse estudo corroboram com a literatura, como os trabalhos descritos por Ishida (2010) e Santos (2014), os quais analisaram um Sistema LatossoloEspodossolo da região Amazônica. Os autores, observaram que nesses solos houve um acúmulo dos metais Alumínio e Ferro nos horizontes Bh, sendo maior valor obtido para o metal Alumínio. Segundo esses autores, essa acumulação é resultado da translocação do metal Ferro, e principalmente do Alumínio na forma de complexos orgânicos para esses horizontes Bh espódicos.

Correlacionado os teores dos metais alumínio e ferro nos Espodossolos hidromórficos (P1) e Espodossolo bem drenado (P4), verificam-se menores valores de coeficientes de correlação para o solo P4. Uma hipótese que nos Espossolos P1, P2 e P3, ocorrem à mobilização dos complexos organometálicos e dos óxidos metálicos, os quais são controlados pela oscilação do nível do lençol freático suspenso. Assim, o Espodossolo hidromórfico propicia maior mobilização dos complexos organometálicos e do ferro reduzido quando comparado ao Espodossolo bem drenado que permite a precipitação do ferro e uma menor mobilização dos complexos organometálicos.

\section{I.4. Considerações parciais}

A partir das caracterizações da MOS empregando o LIFS, os resultados sugerem que menores índices de humificação ocorreram nos horizontes de superfície, os quais podem ser atribuídos à presença de MO mais lábil, isto é, derivadas de plantas e/ou compostos nãohúmicos originados pela ação recente de microorganismos. Além disso, observou-se um aumento da humificação com o decorrer da profundidade nos Espodossolos Amazônicos, especialmente nos perfis P1 e P4, o que pode estar associado ao deslocamento das moléculas mais solúveis e de menor tamanho molecular para os horizontes mais profundos devido aos processos físicos e químicos.

O metal alumínio tem uma maior participação no processo de formação desses solos, uma vez que foram observados maiores quantidades quando comparados ao metal Ferro. Além disso, há uma tendência de aumento desses metais com aumento da profundidade. Uma hipotése lançada é que nesses solos a mobilização dos complexos organometálicos e dos 
óxidos metálicos esteja sendo controlada pela oscilação do nível do lençol freático suspenso, especialmente para os perfis P1, P2 e P3.

Nesses solos, existem a presença de quatro tipos de matéria orgânica as quais são: recalcitrantes, humificada e antiga; lábil e jovem; pouco humificada e antiga; e por fim humificada e jovem, ao correlacionar a datação do ${ }^{14} \mathrm{C}$ com o $\mathrm{H}_{\text {LIFS_M. Assim, fatores como }}$ textura, presença de água e microorganismos influenciaram nos processos de formação e humificação desse material orgânico. Além disso, os compostos orgânicos do tipo lignina parecem ser preservados por muitos anos nos horizontes mais profundos do solo. Portanto, o processo de humificação não tem associação direta com a datação da matéria orgânica nos Espodossolos Amazônicos. 
Capítulo 5 - Resultados e Discussão 


\section{$\underline{\text { Parte II - Caracterização das }}$ frações Húmicas}




\section{II.1. Análise elementar}

Os valores obtidos pela análise elementar dos ácidos húmicos, ácidos fúlvicos e huminas estão expostos na Tabela 5.II.8.

Tabela 5.II.8: Valores de Carbono (\%), Nitrogênio (\%) e Hidrogênio (\%) das frações húmicas dos perfis de Espodossolos Amazônicos. Observação: consideraram-se os teores de cinzas (Anexo B, página 156).

\begin{tabular}{|c|c|c|c|c|c|c|c|c|c|}
\hline \multirow[b]{2}{*}{ Amostras } & \multicolumn{3}{|c|}{ Ácidos Húmicos } & \multicolumn{3}{|c|}{ Ácidos Fúlvicos } & \multicolumn{3}{|c|}{ Huminas } \\
\hline & $\% \mathrm{C}$ & $\% \mathbf{H}$ & $\% \mathbf{N}$ & $\% \mathrm{C}$ & $\% \mathbf{H}$ & $\% \mathbf{N}$ & $\% \mathrm{C}$ & $\% \mathbf{H}$ & $\% \mathrm{~N}$ \\
\hline P1 A 0-15 & $45 \pm 3$ & $2,4 \pm 0,3$ & $1,96 \pm 0,06$ & $18,2 \pm 0,5$ & $\begin{array}{c}2,49 \pm \\
0,04\end{array}$ & $1,0 \pm 0,5$ & $\begin{array}{c}52,03 \pm \\
0,08\end{array}$ & $\begin{array}{c}0,76 \pm \\
0,01\end{array}$ & $\begin{array}{c}0,26 \pm \\
0,01\end{array}$ \\
\hline P1 A 15-30 & $51 \pm 1$ & $\begin{array}{c}3,85 \pm \\
0,05\end{array}$ & $0,96 \pm 0,05$ & $26,9 \pm 0,2$ & $\begin{array}{c}2,45 \pm \\
0,03\end{array}$ & $0,2 \pm 0,1$ & $\begin{array}{c}24,38 \pm \\
0,01\end{array}$ & $*$ & $*$ \\
\hline P1 Bh 40-50 & $56,2 \pm 0,2$ & $\begin{array}{c}4,085 \pm \\
0,005\end{array}$ & $0,90 \pm 0,01$ & $36,8 \pm 0,8$ & $3,1 \pm 0,0$ & $0,1 \pm 0,2$ & $\begin{array}{c}36,67 \pm \\
0,03\end{array}$ & $*$ & $*$ \\
\hline P1 Bh-C 240 & $46 \pm 2$ & $3,6 \pm 0,2$ & $1,16 \pm 0,04$ & $47,9 \pm 0,1$ & $1,4 \pm 0,0$ & $0,4 \pm 0,2$ & $*$ & $*$ & $*$ \\
\hline P1 Bh-C 260 & $47 \pm 1$ & $\begin{array}{c}3,57 \pm \\
0,09\end{array}$ & $1,01 \pm 0,03$ & $26,6 \pm 0,1$ & $2,9 \pm 0,0$ & $0,2 \pm 0,1$ & $\begin{array}{c}3,25 \pm \\
0,00\end{array}$ & $*$ & $*$ \\
\hline P1 C 350 & $51 \pm 3$ & $4,1 \pm 0,1$ & $0,99 \pm 0,03$ & $\begin{array}{c}38,7 \pm \\
0,9 \\
\end{array}$ & $\begin{array}{c}3,12 \pm \\
0,01\end{array}$ & $0,4 \pm 0,0$ & $\begin{array}{c}5,17 \pm \\
0,00\end{array}$ & $*$ & $*$ \\
\hline P2 A 0-15 & $59 \pm 1$ & $3,3 \pm 0,1$ & $2,42 \pm 0,06$ & $\begin{array}{c}20,2 \pm \\
0,3\end{array}$ & $4 \pm 1$ & $0,3 \pm 0,1$ & $*$ & $*$ & $*$ \\
\hline P2 A-E 15-30 & $48,7 \pm 0,5$ & $\begin{array}{c}3,16 \pm \\
0,04\end{array}$ & $1,7 \pm 0,2$ & $28,3 \pm 0,3$ & $1,1 \pm 0,3$ & $\begin{array}{c}0,22 \pm \\
0,02\end{array}$ & $\begin{array}{c}5,83 \pm \\
0,01\end{array}$ & $*$ & $*$ \\
\hline P2 Bh 290 & $50,2 \pm 0,3$ & $\begin{array}{c}3,58 \pm \\
0,08 \\
\end{array}$ & $0,96 \pm 0,03$ & $21 \pm 1$ & $2,7 \pm 1,9$ & $\begin{array}{c}0,23 \pm \\
0,03\end{array}$ & $*$ & $*$ & $\begin{array}{c}0,10 \pm \\
0,01\end{array}$ \\
\hline P3 A 0-15 & $53,9 \pm 0,8$ & $4,7 \pm 0,1$ & $2,58 \pm 0,03$ & $\begin{array}{c}27,2 \pm \\
0,4\end{array}$ & $3 \pm 1$ & $1,2 \pm 0,3$ & $*$ & $*$ & $*$ \\
\hline P3 Bh 165-175 & $46,8 \pm 0,1$ & $3,3 \pm 0,2$ & $0,79 \pm 0,06$ & $53 \pm 2$ & $1,7 \pm 0,1$ & $0,4 \pm 0,1$ & $\begin{array}{c}1,11 \pm \\
0,01\end{array}$ & $*$ & $*$ \\
\hline P3 Bh 180-183 & $54 \pm 6$ & $4,0 \pm 0,4$ & $1,3 \pm 0,1$ & $\begin{array}{c}42,1 \pm \\
0,8\end{array}$ & $2,6 \pm 0,1$ & $\begin{array}{c}0,53 \pm \\
0,03\end{array}$ & $*$ & $*$ & $*$ \\
\hline P3 Bh 210 & $45 \pm 1$ & $\begin{array}{c}2,98 \pm \\
0,00\end{array}$ & $1,2 \pm 0,1$ & $48,6 \pm 0,8$ & $2,2 \pm 0,1$ & $0,5 \pm 0,1$ & $\begin{array}{c}14,00 \pm \\
0,02\end{array}$ & $*$ & $*$ \\
\hline P3 Bh 280-310 & $53 \pm 3$ & $\begin{array}{c}3,25 \pm \\
0,09\end{array}$ & $1,6 \pm 0,3$ & $37,4 \pm 0,1$ & $2,1 \pm 0,3$ & $\begin{array}{c}0,50 \pm \\
0,02\end{array}$ & $\begin{array}{c}1,67 \pm \\
0,01\end{array}$ & $*$ & $*$ \\
\hline P3 Bh 335-350 & $54,2 \pm 0,8$ & $3,5 \pm 0,4$ & $1,17 \pm 0,00$ & $25 \pm 2$ & $1,0 \pm 0,6$ & $\begin{array}{c}0,38 \pm \\
0,04\end{array}$ & $\begin{array}{c}6,67 \pm \\
0,01\end{array}$ & $*$ & $*$ \\
\hline P4 A 0-20 & $45,2 \pm 0,3$ & $\begin{array}{c}3,91 \pm \\
0,04\end{array}$ & $2,65 \pm 0,02$ & $34 \pm 3$ & $1,5 \pm 0,5$ & $\begin{array}{c}0,4 \pm \\
0,1\end{array}$ & $\begin{array}{c}41,43 \pm \\
0,07\end{array}$ & $*$ & $\begin{array}{c}0,10 \pm \\
0,01\end{array}$ \\
\hline P4 A 20-30 & $\begin{array}{c}49,4 \pm \\
0,01\end{array}$ & $\begin{array}{c}4,24 \pm \\
0,02\end{array}$ & $3,30 \pm 0,04$ & $21,6 \pm 0,2$ & $1,5 \pm 0,5$ & $0,4 \pm 0,1$ & 0,0 & $*$ & $*$ \\
\hline P4 A 30-40 & $50 \pm 2$ & $3,4 \pm 0,1$ & $3,0 \pm 0,1$ & $\begin{array}{c}10,8 \pm \\
0,1\end{array}$ & $1,0 \pm 0,1$ & $0,2 \pm 0,1$ & $\begin{array}{c}5,76 \pm \\
0,02\end{array}$ & $*$ & $\begin{array}{c}0,2 \pm \\
0,1\end{array}$ \\
\hline P4 Bh 110-120 & $50,0 \pm 0,1$ & $\begin{array}{c}1,64 \pm \\
0,02\end{array}$ & $1,39 \pm 0,06$ & $\begin{array}{c}39,8 \pm \\
0,6\end{array}$ & $1,6 \pm 0,2$ & $0,4 \pm 0,2$ & $*$ & $*$ & $\begin{array}{c}0,11 \pm \\
0,01\end{array}$ \\
\hline P4 Bh 170-180 & $52 \pm 6$ & $3,0 \pm 0,2$ & $2,6 \pm 0,3$ & $3,1 \pm 0,0$ & $*$ & $*$ & $\begin{array}{c}5,33 \pm \\
0,02\end{array}$ & $*$ & $*$ \\
\hline P4 Bh-C 270-280 & $51 \pm 3$ & $3,4 \pm 0,2$ & $2,9 \pm 0,1$ & $\begin{array}{c}20,0 \pm \\
0,3\end{array}$ & $\begin{array}{c}0,23 \pm \\
0,01\end{array}$ & $\begin{array}{c}0,13 \pm \\
0,03\end{array}$ & $*$ & $*$ & * \\
\hline P4 Bh 370-380 & $52,8 \pm 0,3$ & $\begin{array}{c}3,14 \pm \\
0,01\end{array}$ & $2,26 \pm 0,09$ & $\begin{array}{c}32,8 \pm \\
0,2\end{array}$ & $0,8 \pm 0,3$ & $\begin{array}{c}0,31 \pm \\
0,02\end{array}$ & $\begin{array}{c}2,26 \pm \\
0,01\end{array}$ & $*$ & $*$ \\
\hline P4 Bh 380-390 & $54,5 \pm 0,5$ & $\begin{array}{c}3,25 \pm \\
0,02\end{array}$ & $2,2 \pm 0,1$ & $\begin{array}{c}34,5 \pm \\
0,3 \\
\end{array}$ & $0,7 \pm 0,2$ & $\begin{array}{c}0,27 \pm \\
0,01\end{array}$ & $*$ & $*$ & $*$ \\
\hline
\end{tabular}

*Valores abaixo do limite de deteção do equipamento $(\% \mathrm{C}=0,04 ; \% \mathrm{H}=0,03 ; \% \mathrm{~N}=0,1)$.

Fonte: Autoria própria. 
Na Tabela 5.II.8, mostrou que as frações de ácido húmico obtiveram valores de carbono de 45 a 56,2\% corroborando com estudos descritos na literatura (Senesi et al. 1989; Grasset e Amblès, 1998; Vaz et al. 2015). As frações de ácido fúlvico obtiveram valores menores de 3,1 a 48,6\% de carbono. Esses valores não estão preconizado com o divulgado como sendo padrão pela Sociedade Internacional de Substâncias Húmicas, os quais variam de 49,79 a 51,03\% de carbono. Assim, os valores abaixo de $40 \%$ para as amostras de ácido fúlvico não são confiáveis, conforme apresentado na Tabela 5.II.8. Os valores dos redimento de carbono obtido pelo processo de extração das substâncias húmicas (Tabela 5.II.9, na sessão de Anexo A, página 155), mostrou valores de rendimento de carbono que variaram de 0,06 a 24,42\% para os ácidos fúlvicos, os quais podem estar associados a perda durante o processo de extração e purificação. Enquanto que os ácidos húmicos e humina os valores variaram de 1,52 a $51,02 \%$ e de 0,10 a $93,57 \%$ de carbono, respectivamente.

Os valores de hidrogênio e nitrogênio das frações de ácido húmico e fúlvico estão dentro dos valores descritos na literatura (Rocha e Rosa, 2003; IHSS, 2016) com valores que variam de 0,2 a 4,7 \%. Há poucos estudos que abordam a fração humina (Almendros et al. 1996; Nam e Kim, 2002; Pan et al., 2006; Calace et al. 2007; Tadini et al., 2015), porém os resultados desse trabalho mostraram que essa fração tem valores significantes de carbono na sua estrutura, o que demonstra a sua importância, uma vez que se trata de uma fração conhecida por se ligar fortemente a compostos orgânicos hidrofóbicos, e apresentar biopolímeros inalterados, tais como a lignina e polissacarídeos, na sua estrutura (Nearpass, 1976; Chiou et al., 2000). A fração humina pode representar uma fração maior da MO: cerca de 80-93\% de alguns solos Amazônico. Assim, trata-se de uma importante fração húmica, indicando seu papel na análise ambiental (Tadini et al., 2015, Anexo H, página 166). Os solos apresentados nesse estudo possuem 87 a 99\% de humina inorgânica e 0.90 a 12,3\% de humina orgânica (Tadini et al., 2015).

Nos Espodossolos hidromórficos (P1 e P2) observou-se baixos valores de carbono da fração ácido húmico nos horizontes superficiais, sendo 45\% para o P1 A 0-15 e 48,7\% para o P2 A-E 15-30. Nos Espodossolo hidromorfico (P3) e Espodossolo bem drenado (P4), houve pouca variação na quantidade de carbono considerando o erro analítico da medida, apenas destacando-se o horizonte com $45 \%$ de carbono (P3 Bh 210) e 50\% de carbono (P4 Bh 110120) para as amostras de ácido húmico. Na fração humina os maiores valores de carbono foram nos horizontes superficiais para os Espodossolos P1 e P4. Enquanto que na fração ácido fúlvico, verificou-se pouca variação entre os valores de carbono com o decorrer da profundidade, com exceção dos solos P1 Bh-C 240 e P3 Bh 165-175, com maiores valores de 
carbono de 47 e $53 \%$ respectivamente. Além da determinação elementar da amostra, a análise elementar tem sido utilizada para avaliar o grau de condensação dos anéis aromáticos e a origem das frações húmicas, através do emprego das razões Hidrogênio/Carbono (H/C) e Carbono/Nitrogênio $(\mathrm{C} / \mathrm{N})$, respectivamente. As razões $\mathrm{C} / \mathrm{N}$ e $\mathrm{H} / \mathrm{C}$ foram determinadas nas amostras de ácidos húmicos, ácidos fúlvicos e huminas dos Espodossolos Amazônicos, conforme exibido na Tabela 5.II.10.

A razão $\mathrm{C} / \mathrm{N}$ está associada ao processo de humificação da matéria orgânica (Stevenson 1994; Landgraf et al. 1999; Rocha e Rosa, 2003; Giovanela et al. 2010) e tem sido empregada como fonte de informação a respeito da quantidade de nitrogênio e carbono incorporado no material húmico, ou seja, em geral amostras contendo material mais humificado apresentaram maiores valores de C/N (Rocha e Rosa, 2003; Vaz Jr. et al. 2015).

Tabela 5.II.10: Valores das razões $\mathrm{C} / \mathrm{N}$ e $\mathrm{C} / \mathrm{H}$ das frações húmicas dos solos Amazônicos.

\begin{tabular}{|c|c|c|c|c|c|c|}
\hline \multirow[b]{2}{*}{ Amostras } & \multicolumn{2}{|c|}{ Ácido Húmico } & \multicolumn{2}{|c|}{ Ácido Fúlvico } & \multicolumn{2}{|c|}{ Humina } \\
\hline & $\mathbf{C} / \mathbf{N}$ & $\mathrm{H} / \mathrm{C}$ & $\mathrm{C} / \mathrm{N}$ & $\mathbf{H} / \mathbf{C}$ & $\mathbf{C} / \mathbf{N}$ & H/C \\
\hline P1 A 0-15 & 22,6 & 0,7 & 20 & 1,7 & 29,3 & 0,7 \\
\hline P1 A 15-30 & 60,4 & 0,9 & 30 & 7,1 & $*$ & $*$ \\
\hline P1 Bh 40-50 & 68,5 & 0,9 & 55 & 7,6 & $*$ & $*$ \\
\hline P1 Bh-C 240 & 46,3 & 0,9 & 28 & 1,7 & $*$ & $*$ \\
\hline P1 Bh-C 260 & 49,5 & 1,0 & 28 & 7,6 & $*$ & $*$ \\
\hline P1 C 350 & 56,5 & 1,0 & 22 & 5,0 & $*$ & $*$ \\
\hline P2 A 0-15 & 19,5 & 1,0 & 22 & 9,5 & $*$ & $*$ \\
\hline P2 A-E 15-30 & 24,1 & 1,1 & 27 & 2,6 & $*$ & $*$ \\
\hline P2 Bh 290 & 58,0 & 0,9 & 28 & 5,8 & 0,3 & $*$ \\
\hline P3 A 0-15 & 24,1 & 1,1 & $*$ & $*$ & $*$ & $*$ \\
\hline P3 Bh 165-175 & 66,8 & 0,9 & 47 & 1,4 & $*$ & $*$ \\
\hline P3 Bh 180-183 & 49,8 & 0,9 & 48 & 1,4 & $*$ & $*$ \\
\hline P3 Bh 210 & 37,6 & 1,0 & 28 & 2,2 & $*$ & $*$ \\
\hline P3 Bh 280-310 & 38,1 & 0,8 & 21 & 2,7 & $*$ & $*$ \\
\hline P3 Bh 335-350 & 53,6 & 0,8 & 15 & 2,5 & $*$ & $*$ \\
\hline P4 A 0-20 & 18,2 & 1,1 & 18 & 2,6 & 3,0 & $*$ \\
\hline P4 A 20-30 & 16,6 & 1,1 & 13 & 4,4 & $*$ & $*$ \\
\hline P4 A 30-40 & 15,7 & 1,0 & 13 & 4,9 & 2,0 & $*$ \\
\hline P4 Bh 110-120 & 22,2 & 0,7 & 20 & 2,6 & 1,5 & $*$ \\
\hline P4 Bh 170-180 & 22,3 & 0,7 & $*$ & $*$ & $*$ & $*$ \\
\hline P4 Bh-C 270-280 & 20,9 & 0,8 & 19 & 1,3 & $*$ & $*$ \\
\hline P4 Bh 370-380 & 25,5 & 0,8 & 16 & 2,2 & $*$ & $*$ \\
\hline P4 Bh 380-390 & 26,8 & 0,8 & 22 & 1,8 & $*$ & $*$ \\
\hline
\end{tabular}

*Valores não determinados, pois estavam abaixo do limite de deteção no \%C ou \%H ou \%N.

Fonte: Autoria própria. 
Segundo Rocha e Rosa (2003), os ácidos húmicos apresentam menor razão H/C que está associada a uma estrutura mais aromática e condensada que as frações de ácidos fúlvicos, como verificado nos resultados exibidos na Tabela 5.II.10. Essa razão refere-se à quantidade de hidrogênio presente na estrutura da matéria orgânica, permintindo associar ao grau de alifacidade do material húmico, ou seja, quanto maior a razão, maior é o número de carbonos alifáticos $\left(\mathrm{CH}_{2}\right)$, e consequentemente, há uma diminuição de carbonos aromáticos $(\mathrm{C}=\mathrm{C})$ na estrutura das frações húmicas (Stevenson 1994; Sargentini Junior et al. 2001; Rocha e Rosa, 2003; Allard, 2006; Zhang et al. 2011; Vaz Jr. et al. 2015).

Analisando os dados exibidos na Tabela 5.II.10, verificou-se que as menores razões $\mathrm{C} / \mathrm{N}$ ocorreram nos horizontes superficiais das frações de ácido húmico e fúlvico dos quatros Espodossolos Amazônicos. Sugerindo assim, que nesses horizontes superficiais há incorporação de um material mais fresco e lábil, caracterizado por um material menos humificado e com estruturas mais alifáticas.

Nos Espodossolos hidromórficos P1 e P3 obtiveram comportamentos semelhantes para a razão $\mathrm{C} / \mathrm{N}$ dos ácidos húmicos em que nos horizontes $\mathrm{Bh}$ intermediários e mais profundos, houve um aumento dessa razão, permintindo associar a um aumento de carbono mais humificado com estruturas aromáticas associados, conforme observado na Tabela 5.II.10. Esse aumento com o decorrer da profundidade é nítido para as amostras dos Espodossolo hidromórfico e bem drenado, P2 e P4, respectivamente. Esse fato pode ser devido ao aporte de carbono proveniente da vegetação, permitindo uma maior adição de substâncias orgânicas nessas frações, o que acarreta em um aumento da atividade microbiana, principalmente nos horizontes superficiais, promovendo a mineralização da matéria orgânica e consequentemente liberando os nutrientes para o solo (Ribeiro, 2007). Além disso, os resultados de $\mathrm{C} / \mathrm{N}$ mostraram que a fração de ácido húmico apresenta um contéudo mais humificado nos horizontes mais profundos, nos quais foram verificados os maiores valores de $\mathrm{C} / \mathrm{N}$, quanto comparados às demais frações, ácidos fúlvicos e huminas.

Destaca-se ainda nos horizontes P1 Bh 240, P2 A-E 15-30, P3 Bh 180-183 e P4 Bh 380-390 das amostras de ácido fúlvico (Tabela 5.II.10) houve uma menor razão H/C porém uma maior razão $\mathrm{C} / \mathrm{N}$ foi observado para esses horizontes, caracterizando amostras mais humificadas. De maneira geral, os valores da razão H/C para as amostras de ácido húmico foram menores que alguns estudos descritos na literatura (Senesi et al. 1989; Grasset e Amblès, 1998; Rocha e Rosa, 2003; Vaz Jr. et al 2015; Boguta et al. 2016; Volikov et al. 2016) que mostraram valores acima de 1,0. Este comportamento sugere que os menores valores para a razão H/C podem estar associados há um aumento de cadeias alifáticas na 
estrutura das substâncias húmicas. Assim, uma diminuição da razão H/C pode estar associada à perda de hidrogênio e um aumento na conjugação da estrutura da matéria orgânica, em estrutura mais aromáticas, o que foi comprovado pelo aumento da razão $\mathrm{C} / \mathrm{N}$ nesses horizontes (P1 Bh 40-50; P2 Bh 290; P3 Bh 165-175 e P3 Bh 335-350). Horizontes estes, que tem influência direta do lençol freático suspenso, dando condições a ambientes anaeróbicos nesses solos.

Ademais, ressalta-se que foi realizado teste de cinzas para todas as amostras de ácido húmico, ácido fúlvico e humina, os quais foram exibidos na Tabela 5.II.11 na sessão de Anexos (Anexo B, página 156). Os resultados obtidos do teste de cinza mostraram que a fração humina há presença de matéria orgânica, cujo valor variou de 0,5 a 54,1\%. Deste modo, demonstrando que mesmo por ser uma fração mais arenosa, é possível obter a contribuição da matéria orgânica em sua estrutura, permitindo inferir a sua importância em estudos ambientais.

\section{II.2. Estudo da Espectrometria de Infravermelho com Transformada de Fourier}

As Figuras 5.II.13 a 5.II.15 exibem um espectro típico obtido das amostras de ácido húmico, ácido fúlvico e humina para os Espodossolos Amazônicos, representado pelo Solo P1. Os demais espectros de FTIR dos Solos P2, P3 e P4 foram apresentados nas Figuras 5.II.16 a 5.II.18, na sessão de Anexos (Anexo C, páginas 157).

Figura 5.II.13: Espectro típico de Infravermelho de Ácido Húmico extraído do Espodossolo Hidromórfico (P1).

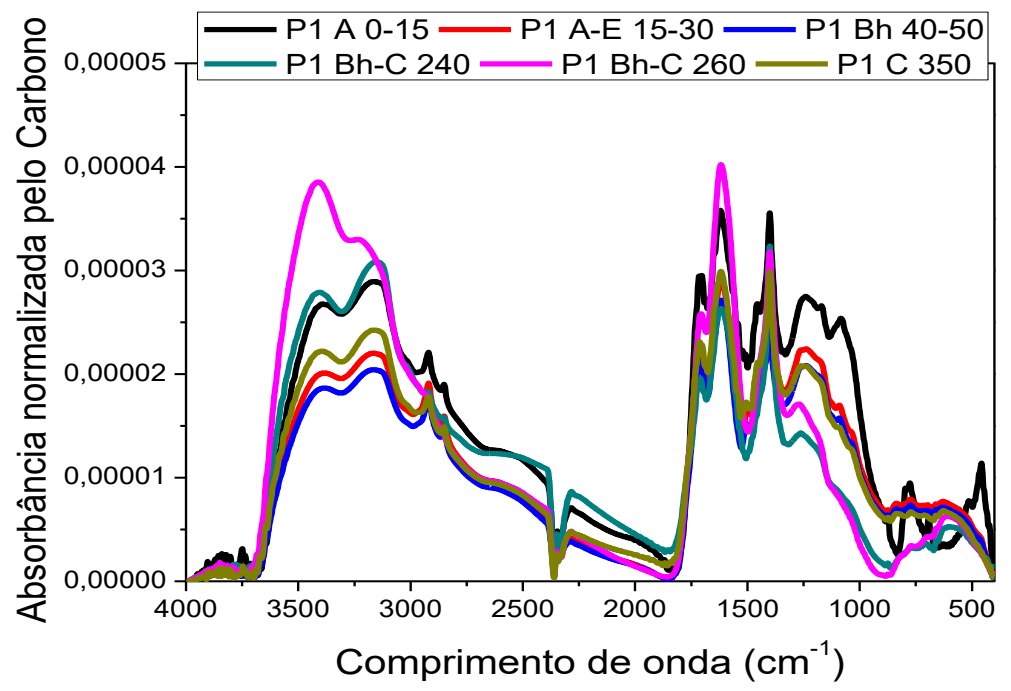

Fonte: Autoria própria.

Na Figura 5.II.13, verifica-se a presença de duas bandas entre 3.440 a $3.100 \mathrm{~cm}^{-1}$ a 
qual pode ser atribuída ao estiramento e deformação de ligação $\mathrm{OH}$, ligação de Si-O presente em minerais e de estiramento de grupos carboxílicos. Uma banda na região de 2.920 a 2.900 $\mathrm{cm}^{-1}$ pode ser atribuído a presença de estiramentos $\mathrm{C}-\mathrm{H}$ de grupos metilas e metilenos alifáticos, uma banda na região de 1.710 a $1.730 \mathrm{~cm}^{-1}$ pode ser conferida a vibrações de carbonilas de grupos carboxilatos e/ou cetonas (Havers et al. 1998; Araújo et al. 2002; Rocha e Rosa, 2003; Giovanela et al. 2010; Rodríguez e Núñez, 2011), uma banda na região de 1.600 a $1.620 \mathrm{~cm}^{-1}$ associada a presença de vibrações de estiramento de $\mathrm{C}=\mathrm{C}$ de alcenos conjugados e estiramento de $\mathrm{COO}^{-}$e $\mathrm{C}=\mathrm{O}$ de quinonas. Bandas na região de 1.400 a 1.390 $\mathrm{cm}^{-1}$ podem ser conferida a estiramento $\mathrm{OH}$ de fenóis e deformação de ligações de $\mathrm{CH}_{2} \mathrm{e}$ $\mathrm{CH}_{3}$ e/ou estiramento assimétrico de $\mathrm{COO}^{-}$. Regiões de 1.280 a $1.200 \mathrm{~cm}^{-1}$ atribuem-se a presença de deformação $\mathrm{OH}$ de grupos carboxílicos e estiramentos de C-O-C de aril éter e fenóis, e bandas nas regiões de 1.100 a $1.000 \mathrm{~cm}^{-1}$ associadas à presença de polissacarídeos. As mesmas bandas relatadas acima foram observadas nas outras amostras de ácido húmico extraídos dos solos P2, P3 e P4, conforme pode ser verificado nas Figuras 5.II.16 a 5.II.18, na sessão de Anexos (Anexo C, página 157).

A Figura 5.II.14 apresenta o espectro típico de uma amostra de ácido fúlvico extraído de Espodossolo Amazônico. Pode-se observar uma banda na região de 3.800 a $3.000 \mathrm{~cm}^{-1}$ que pode ser atribuída às vibrações de $\mathrm{OH}$ ou N-H livres presente na estrutura dos AF.

Figura 5.II.14: Espectro típico de Infravermelho de Ácido Fúlvico extraído do Espodossolo Hidromórfico (P1).

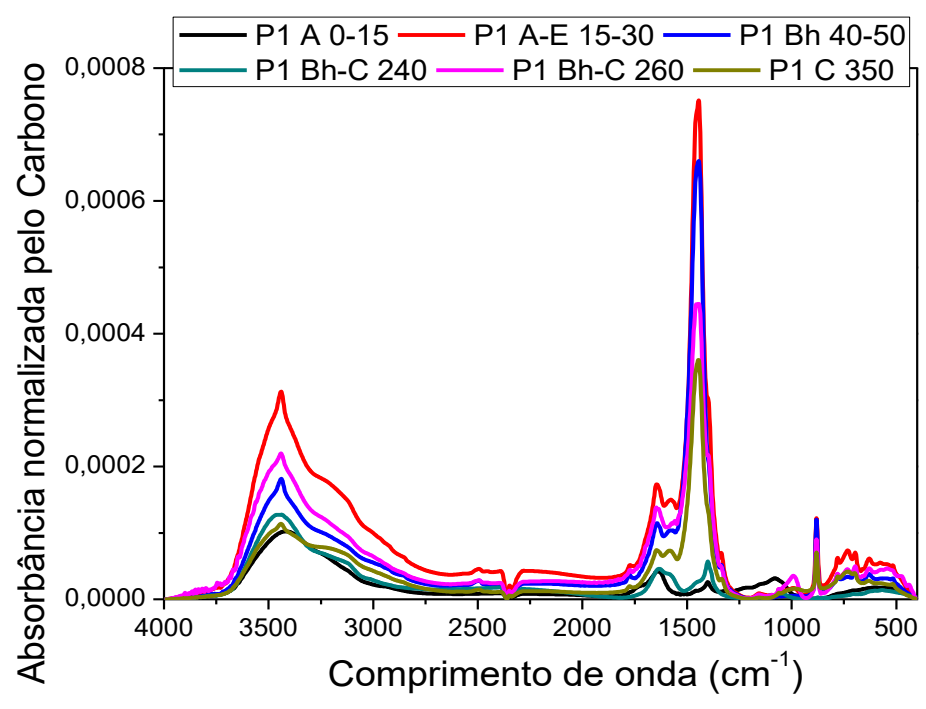

Fonte: Autoria própria.

Na Figura 5.II.14 foi possível verificar uma banda em $1.650 \mathrm{~cm}^{-1}$ pode ser conferida a 
deformação axial assimétrica de grupos carboxilatos e $1.643 \mathrm{~cm}^{-1}$ atribuído à vibração de duplas ligações de conjugados. Banda na região de 1.550 a $1.507 \mathrm{~cm}^{-1}$ que pode ser atribuída à presença de grupos amidas. Banda na região de 1.400 a $1.465 \mathrm{~cm}^{-1}$ pode atribuídas a presença de grupamentos $\mathrm{CH}_{3}$ e $\mathrm{CH}_{2}$ dando um caráter mais alifático à estrutura dos $\mathrm{AF}$. Pode-se verificar uma banda na região 900 a $650 \mathrm{~cm}^{-1}$ que expressa o grau de substituição de átomos nas ligações de grupamentos aromáticos (Rocha e Rosa, 2003; Schiavo et al. 2007; Giovanela et al. 2010; Rodríguez e Núñez, 2011), o mesmo comportamento foi observado nos demais Espodossolos P2, P3 e P4 como exibido nas Figuras 5.II.16 a 5.II.18, na sessão de Anexos (Anexo C, página 157).

A Figura 5.II.15 apresenta um espectro típico obtido do FTIR para amostra de humina extraída do Espodossolo Amazônico.

Figura 5.II.15: Espectro típico de Infravermelho de Humina extraído do Espodossolo Hidromórfico (P1).

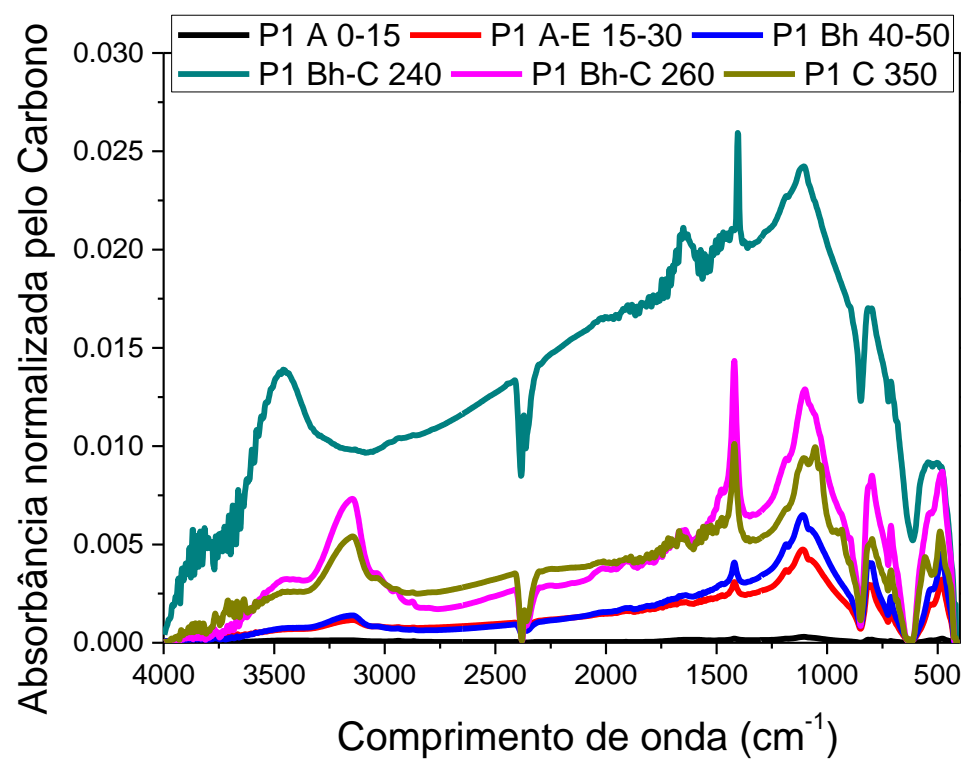

Fonte: Autoria própria.

Na Figura 5.II.15 pode-se verificar a presença de uma banda na região de 3.500 a $3.300 \mathrm{~cm}^{-1}$ podem ser conferida a estiramento $\mathrm{OH}$ de alcoóis e/ou fenóis e/ou grupos carboxílicos. Uma banda na região 2.920 a $2.850 \mathrm{~cm}^{-1}$ que pode ser atribuída a vibrações de $\mathrm{CH}$ de grupos alifáticos. Na região de 1.000 a $1.200 \mathrm{~cm}^{-1}$ observa-se uma banda a qual pode ser atribuída à vibração de Si-O-Si e Si-O-Al presente em estruturas inorgânicas de silicatos. Uma banda na região de 800 a $600 \mathrm{~cm}^{-1}$ foi verificada que pode ser atribuído a materiais 
silicatos de granulação fina, de óxidos de ferro, goetita e hematita (Russel e Fraser, 1994; Galves e Lombardi, 2010).

Destaca-se, para o Espodossolo hidromórfico (P2) no horizonte superficial P2 A 0-15, mostrou diferentes picos os quais não apareceram no decorrer da profundidade para esse solo (Figura 5.II.16(c) - Anexo C: Página 157). Os picos foram: 3.477, 2.922, 2.846 e $1.614 \mathrm{~cm}^{-1}$ referindo-se a contribuição de $\mathrm{O}-\mathrm{H}$ alifático, deformação axial assimétrica de $\mathrm{C}-\mathrm{H}$ de metil e metileno, e deformação axial de $\mathrm{C}=\mathrm{C}$ de anéis aromáticos.

As bandas 796 a $457 \mathrm{~cm}^{-1}$ foram mais intensas nas amostras até $50 \mathrm{~cm}$ de profundidade, a qual se refere à deformação angular de $\mathrm{O}-\mathrm{H}$ de gibbsita ou caolinita e/ou deformação angular de Si-O em caulinita. Já a banda $1.087 \mathrm{~cm}^{-1}$ foi mais intensa no perfil mais profundo para amostra P2 Bh 290 (Figura 5.II.16(c) na sessão Anexo C, página 157), a qual refere-se a deformação axial de C-O de polissacarídeos. No Espodossolo hidromórfico (P3) pode-se verificar que pico em $3.458 \mathrm{~cm}^{-1}$, o qual apareceu apenas no horizonte P3 Bh 210 (Figura 5.II.17(c) sessão de Anexo C, página 157). Enquanto que a banda $1.464 \mathrm{~cm}^{-1} \mathrm{e}$ a faixa de picos de 1.087 a $457 \mathrm{~cm}^{-1}$ foram mais intensos no Espodossolo bem drenado (P4) no horizonte P4 A 20-30, conforme apresentado na Figura 5.II.18(c) (Anexo C, página 157).

Para uma melhor compreensão dos espectros obtidos pelo FTIR, foram selecionados 5 picos principais presente nas amostras de ácido húmico, ácido fúlvico e humina extraídos dos Espodossolos Amazônico, conforme apresentado na Tabela 5.II.12.

Tabela 5.II.12: Representação dos picos de intensidade da banda pelo FTIR das frações húmicas extraídas dos Espodossolos Amazônico.

\begin{tabular}{c|c|c}
\hline Picos & Frequência $\left(\mathbf{c m}^{\mathbf{- 1}}\right)$ & Descrição: \\
\hline 1 & 3.440 a 3.100 & Deformação axial de O-H em grupo fenólico \\
2 & 2.940 a 2.900 & Deformação axial assimétrica de C-H em grupos metilas e metilenos alifáticos \\
3 & 1.720 a 1.660 & Deformação axial de C=O em grupos carboxílicos \\
4 & 1.590 & Deformação axial de C=C em anel aromático \\
5 & 1.050 & Deformação axial de C-O em polissacarídeos \\
\hline
\end{tabular}

Os picos selecionados estão exibidos nas Figuras 5.II.19 a 5.II.22, os quais foram relacionados à intensidade da banda de cada pico avaliado em todas as amostras estudadas. 
Figura 5.II.19: Picos da intensidade da banda das amostras de: (a) ácido húmico, (b) ácido fúlvico e (c) humina extraídos do Espodossolo Hidromórfico (P1).
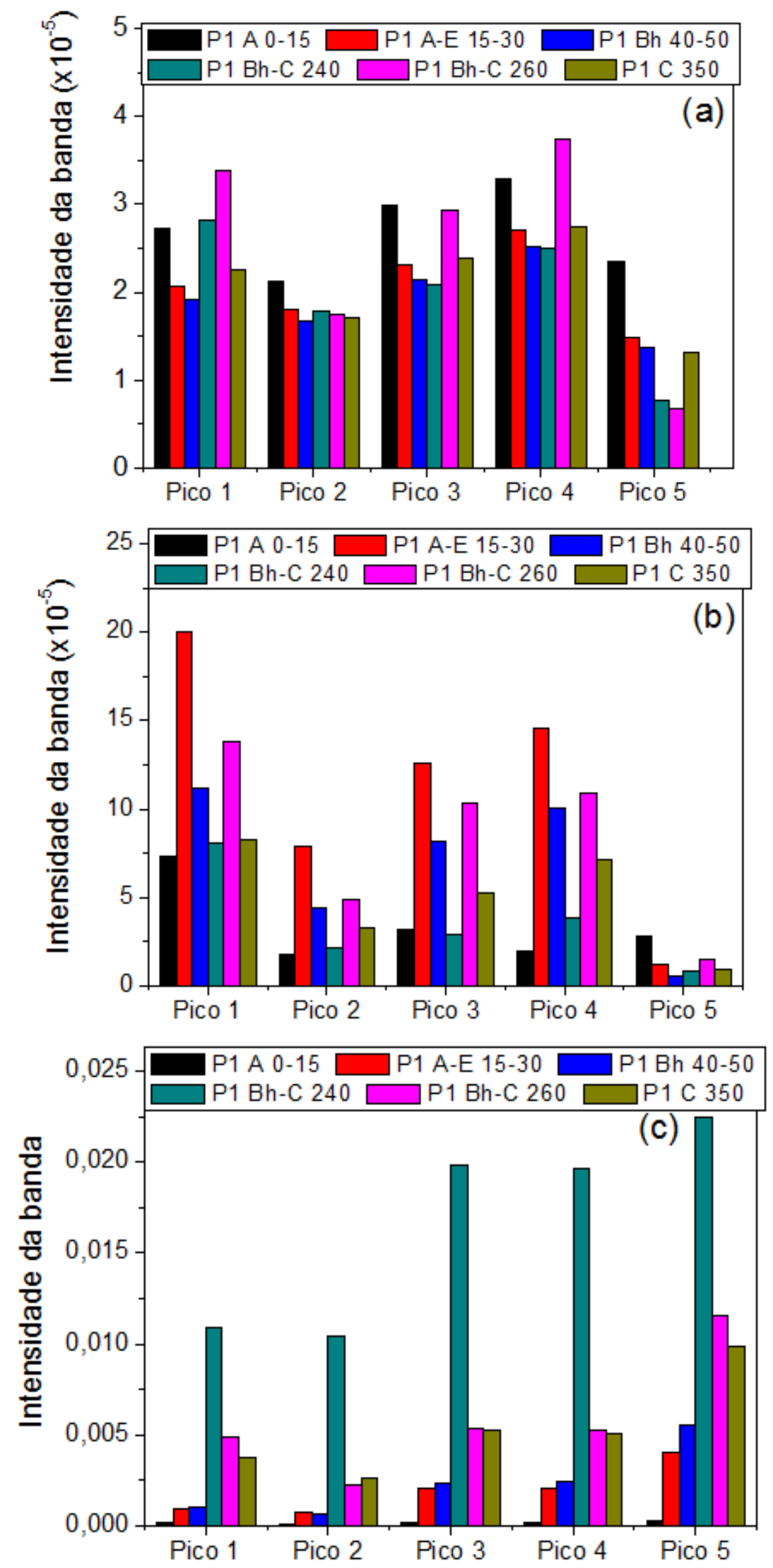

Fonte: Autoria própria. 
Na Figura 5.II.19(a) a intensidade dos Picos 1, 3 e 4 dos ácidos húmicos, atribuídos a presença de hidroxila de grupos fenólicos, ligações de $\mathrm{C}=\mathrm{O}$ de carboxílicos e $\mathrm{C}=\mathrm{C}$ de anéis aromáticos, respectivamente, foram maiores no horizonte $\mathrm{P} 1 \mathrm{Bh}-\mathrm{C} 260$ sugerindo uma maior aromaticidade nesse horizonte. Destaca-se o horizonte superficial P1 A 0-15 que teve uma maior intensidade no Pico 5, referente à presença de polissacarídeos, demonstrando a incoporação de um material mais lábil no horizonte superficial.

Na Figura 5.II.19(b) observou-se que no horizonte P1 A-E 15-30 há uma maior intensidade de banda para os Picos 1, 2, 3 e 4 em relação aos demais horizontes. Assim, sugerindo que os ácidos fúlvicos desse tipo de Espodossolo tem uma mistura complexa em sua estrutura, com contribuição de estruturas simples presentes em grupos metilas e metilenos alifáticos (Pico 2), mas também a presença de grupos funcionais maiores, como fenólicos e carboxílicos (Picos 1 e 3). Para a fração humina observou-se um aumento crescente da intensidade da banda em relação aos Picos 1 a 5 no horizonte P1 Bh-C 240, sendo a maior intensidade para o Pico 5, refere-se a presença de polissacarídeos nas sua estrutura, conforme apresentado na Figura 5.II.19(c).

Na Figura 5.II.20 exibe os picos de intensidade da banda das frações húmicas do Espodossolo hidromórfico P2. Pode-se observar para as amostras de ácido húmico (Figura 5.II.20(a)) que a intensidade da banda no horizonte superficial (P2 A 0-15) foi para os Picos 1 e 3, referentes à presença de grupos fenólicos e ligação $\mathrm{C}=\mathrm{O}$ de grupos carboxílicos, enquanto que no horizonte mais profundo, P2 Bh 290, observou-se uma maior contribuição de ligações $\mathrm{C}=\mathrm{O}$ e $\mathrm{C}=\mathrm{C}$ presente em grupos carboxílicos e anéis aromáticos.

Esse mesmo horizonte, P2 Bh 290 das amostras de ácido fúlvico obtiveram comportamento semelhante ao perfil superficial, em que a maior intensidade de banda foi obtido para o Pico 1, atribuído a presença de ligação $\mathrm{OH}$ de grupos fenólicos, conforme apresentado na Figura 5.II.20(b). Nas amostras da fração humina para esse solo P2 (Figura 5.II.20(c)) observou-se um aumento crescente da intensidade de banda para o Pico 5, referente à presença de polissacarídeos na sua estrutura. 
Figura 5.II.20: Picos da intensidade da banda das amostras de: (a) ácido húmico, (b) ácido fúlvico e (c) humina extraídos do Espodossolo Hidromórfico (P2).
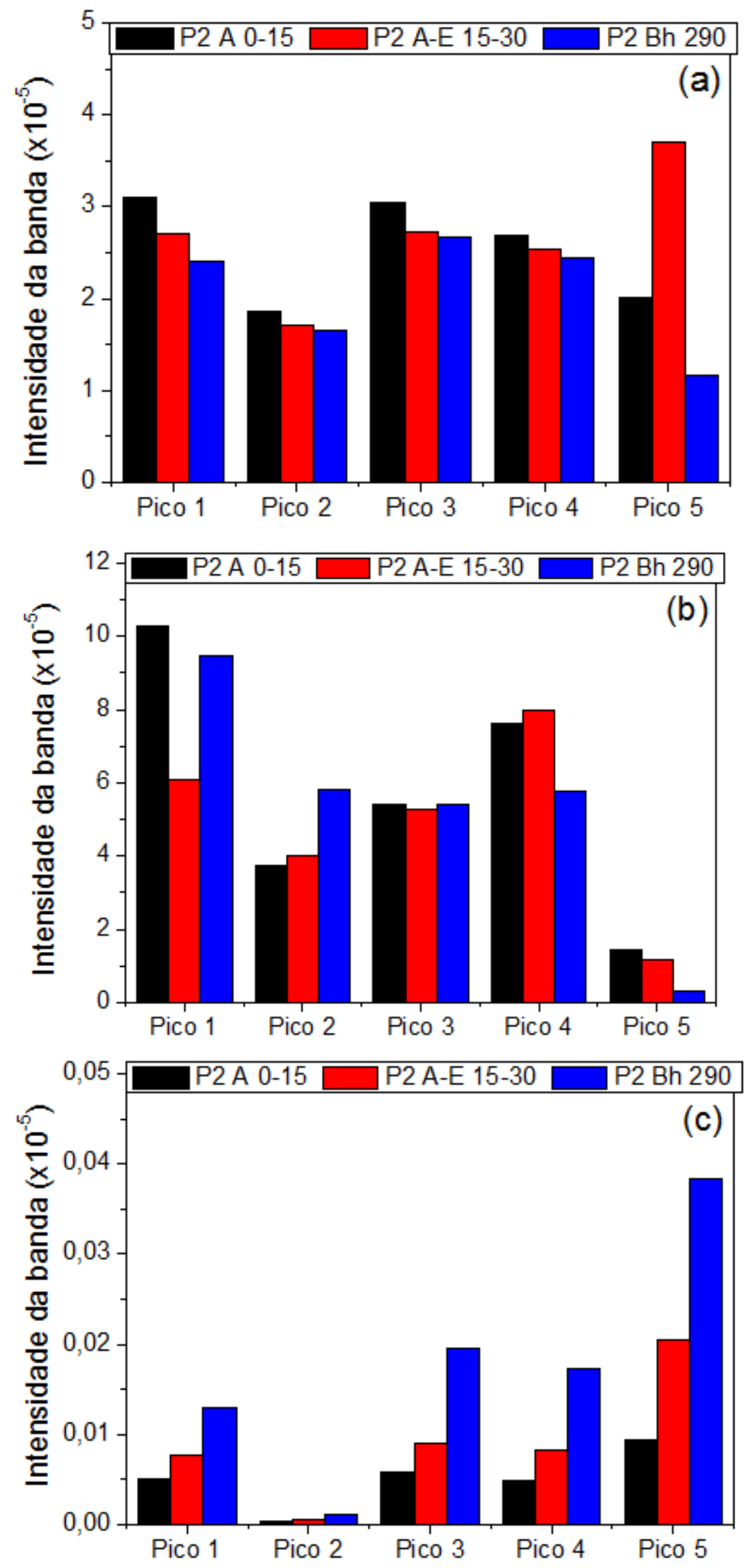

Fonte: Autoria própria. 
A Figura 5.II.21 apresenta as intensidades da banda obtidas pelo FTIR das frações húmicas extraídas do solo P3. Pode-se observar uma maior intensidade da banda para o horizonte superficial até o P3 Bh 180-183 correspondente ao Pico 1 e 3 para as amostras de ácido húmico (Figura 5.II.21(a)), os quais referem-se a presença de grupos fenólicos e carboxílicos.

Nas frações de ácido fúlvico, dois horizontes a serem destacados foram o horizonte superficial e o mais profundo, P3 A 0-15 e P3 Bh 335-350, respectivamente, conforme apresentado na Figura 5.II.21(b). Horizontes estes, que apresentaram maior intensidade de banda para o Pico 1, referente à presença da deformação axial de $\mathrm{O}-\mathrm{H}$ em grupo fenólico. $\mathrm{O}$ Pico 5 (polissacarídeos) nessa fração húmica apresentou menor intensidade de banda para todos os horizontes analisados.

A Figura 5.II.21(c) exibiu um aumento dos picos selecionados em função dos horizontes analisados para a fração humina, sendo a maior intensidade para o Pico 5, referente à presença de polissacarídeos, os quais foram mais intenso nos horizontes Bh (P3 Bh 165-175 e P3 Bh 280-310). 
Figura 5.II.21: Picos da intensidade da banda das amostras de: (a) ácido húmico, (b) ácido fúlvico e (c) humina extraídos do Espodossolo Hidromórfico (P3).
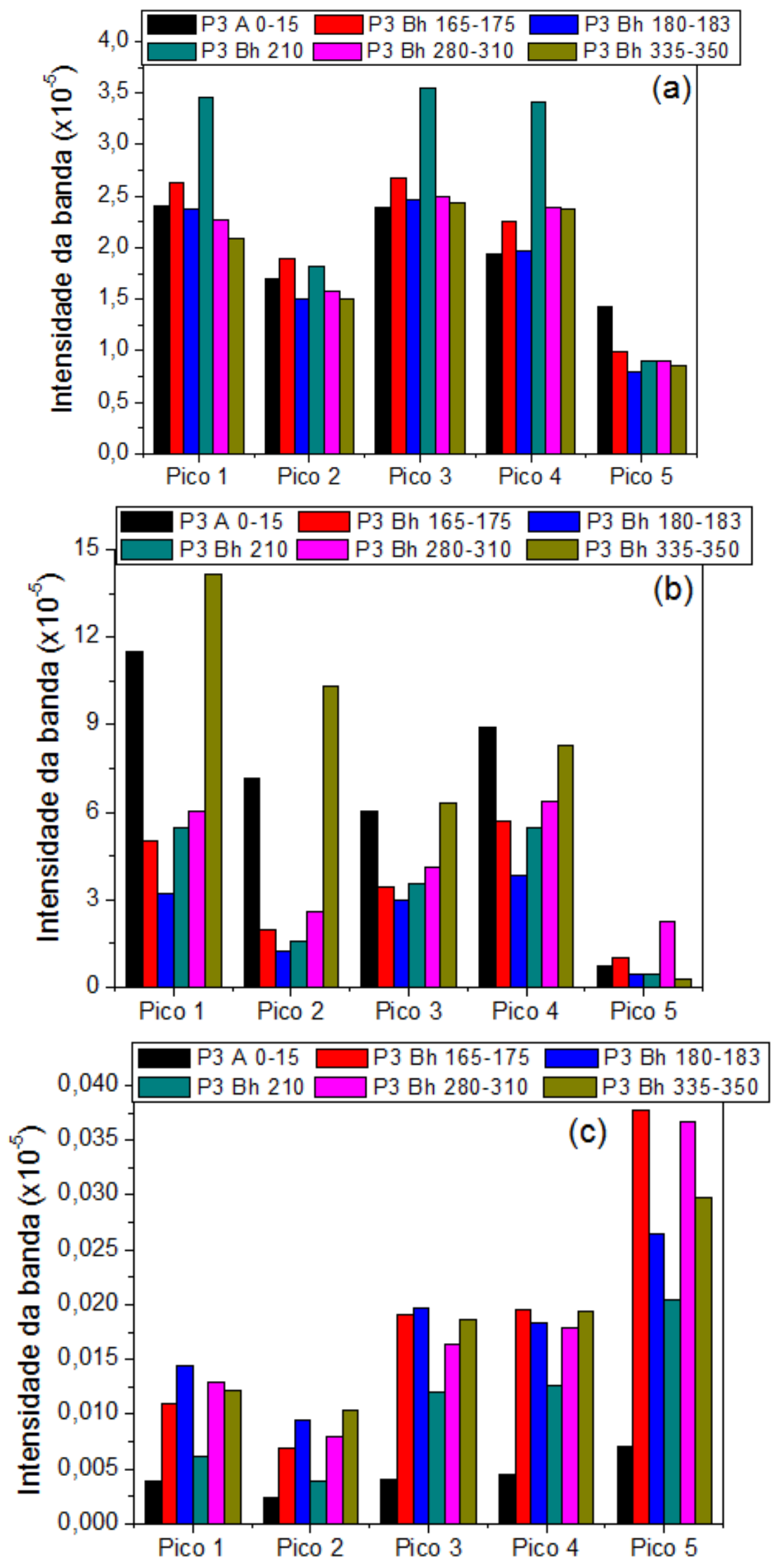

Fonte: Autoria própria. 
A Figura 5.II.22 exibe a intensidade dos picos das frações húmicas extraídas do Espodossolo bem drenado (P4). Pode-se observar para a fração ácido húmico que houve pouca variação entre os horizontes para os cincos picos, destacando-se apenas o horizonte P4 Bh 110-120, cuja a maior intensidade de banda foram para os Picos 3 e 4, os quais referem-se a deformação axial de $\mathrm{C}=\mathrm{O}$ e $\mathrm{C}=\mathrm{C}$ em grupos carboxílicos e aromáticos, e mostrando uma maior presença de polissacarídeos no horizonte superficial para essa fração, conforme apresentado na Figura 5.II.22(a).

Os ácidos fúlvicos desse Espodossolo (Figura 5.II.22(b)), mostrou um aumento crescente com o decorrer do horizonte para os Picos 1 e 2, que se refere a uma estrutura com grupos mais simples, tais como grupos metilas e metilenos alifáticos. Na fração humina, Figura 5.II.22(c), pode-se verificar que a presença da banda de polissacarídeos foi maior em todos os horizontes estudados, sendo mais intenso nos horizontes, subsuperficie e Bh mais profundos (P4 A 20-30, P4 Bh-C 270-280 e P4 Bh 370-380). Destaca-se também nessa fração o horizonte P4 Bh 380-390, houve uma maior intensidade da banda da deformação axial de O-H de grupos fenólicos.

De maneira geral, os resultados do FTIR mostraram comportamentos semelhantes para todas as amostras de ácido húmico, ácido fúlvico e humina extraídos dos quatros Espodossolos Amazônico. Destacando-se apenas para os Espodossolos hidromórficos P1, P2 e P3, o Pico 1 que é atribuído aos grupos carboxílicos, foi mais intenso em maiores profundidades, enquanto que para o Espodossolo bem drenado P4, esse Pico foi mais intenso nos horizontes superficiais. Ressalta-se o Pico 4 referente aos grupos aromáticos foi observado para os quatros Espodossolos estudados (P1, P2, P3 e P4). Sendo esta banda, mais intensa nos horizontes mais profundos, podendo associar a presença de um material mais humificado nesses horizontes. 
Figura 5.II.22: Picos da intensidade da banda das amostras de: (a) ácido húmico, (b) ácido fúlvico e (c) humina extraídos do Espodossolo Bem Drenado (P4).
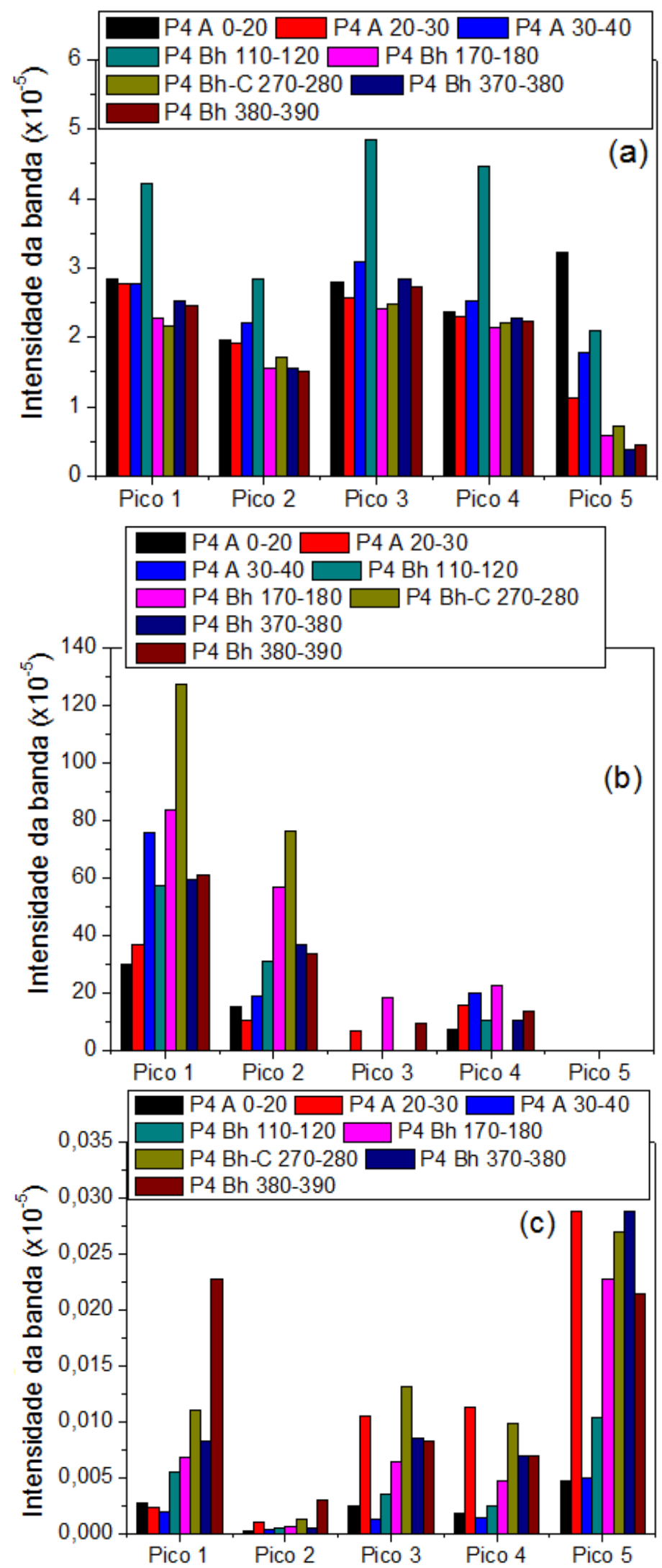

Fonte: Autoria própria. 
Especificamente, as frações de ácido húmico dos Espodossolos Amazônico aparesentaram presença de grupos contendo ligações do tipo $\mathrm{C}=\mathrm{C}$ e $\mathrm{C}=\mathrm{O}$, os quais podem ser oriundos de cadeias aromáticas e carboxílicas, nos horizontes mais profundos, especialmente nos horizontes $\mathrm{Bh}$, permitindo inferir uma maior condensação estrutural com decorrer da profundidade para esse tipo de solo. Em contrapartida, o horizonte superficial dos Espodossolos P2 e P4 observou-se uma maior predonância de polissacarídeos, o que remete a uma matéria orgânica mais "fresca". A análise da fração de ácido fúlvico mostrou que nos horizontes $\mathrm{Bh}$ mais profundos há maior presença de ligação do tipo $\mathrm{C}=\mathrm{O}$ e $\mathrm{OH}$ pertencentes a grupos carboxílicos e fenólicos, especialmente nos Espodossolos do solos P2 e P3, sugerindo que essa fração possui uma estrutura molecular mais simples. A fração humina mostrou fortemente a banda referente aos polissacarídeos, o qual aumenta com o decorrer da profundidade principalmente para os Espodossolos P1 e P2, enquanto que nos Espodossolos P3 e P4, mostrou maior contribuição nos horizontes superficiais. Demonstrando a importância de estudar essa fração, uma vez que a sua constituição não é apenas de um material mais humificado.

\section{II.3. Estudo da Espectrometria de Fluorescência}

\section{II.3.1. Determinação dos índices de humificação}

Os espectros obtidos empregando as metodologias proposta por Kalbitz et al. (1999) e Milori et al. (2002) foram apresentados nas Figuras 5.II.23 a 5.II.30 na sessão de Anexo D (páginas 158 a 161), a fim de avaliar o índice de humificação. A partir dos espectros bidimensionais obtidos foi possível determinar o índice de humificação para cada metodologia empregada, e os resultados estão apresentados na Tabela 5.II.13.

Para os Ácidos Húmicos do Espodossolo hidromórfico (P1), observou-se um aumento com o decorrer da profundidade nos índices de humificação, sendo os maiores valores encontrados nos horizontes Bh-C mais profundo (P1 Bh-C 240 e P1 Bh-C 260) para as duas metodologias analisadas, enquanto que os menores valores foram encontrados nos horizontes superficiais. O mesmo comportamento foi verificado para o Espodossolo hidromórfico P2 e P3, cujos maiores valores foram nos horizontes Bh (P2 Bh 290 e P3 Bh 280-310). No Espodossolo bem drenado P4, verificou-se um aumento gradativo com o decorrer da profundidade, principalmente para os índices de humificação proposto por Kalbitz et al. (1999) e Milori et al. (2002), em que os maiores valores foram obtidos para os horizontes mais profundos, P4 Bh 370-380 e P4 Bh-C 380-390. 
Tabela 5.II.13: Valores do índice de humificação obtido das amostras de ácido húmico e fúlvico aplicando as metodologias propostas por Kalbitz et al. (1999) e Milori et al. (2002) empregando a fluorescência bidimensional.

\begin{tabular}{|c|c|c|c|c|}
\hline \multirow{2}{*}{$\begin{array}{l}\text { Amostra / } \\
\text { Horizonte }\end{array}$} & \multicolumn{2}{|c|}{ Ácido Húmico } & \multicolumn{2}{|c|}{ Ácido Fúlvico } \\
\hline & $\mathbf{I}_{450 \mathrm{~nm}} / \mathbf{I}_{\mathbf{3 7 0 n m}}$ & $\mathbf{A}_{465 \mathrm{~nm}}$ & $\mathbf{I}_{450 \mathrm{~nm}} / \mathbf{I}_{370 \mathrm{~nm}}$ & $\mathbf{A}_{465 \mathrm{~nm}}$ \\
\hline P1 A $0-15$ & 0,55 & 3.773 & 0,11 & 972 \\
\hline P1 A-E 15-30 & 1,02 & 7.799 & 0,13 & 1.008 \\
\hline P1 Bh 40-50 & 0,99 & 7.543 & 0,23 & 1.870 \\
\hline P1 Bh-C 240 & 1,56 & 15.900 & 0,25 & 2.882 \\
\hline P1 Bh-C 260 & 1,37 & 11.956 & 0,12 & 1.149 \\
\hline P1 C 350 & 1,10 & 9.144 & 0,18 & 1.282 \\
\hline P2 A $0-15$ & 0,38 & 2.725 & 0,77 & 517 \\
\hline P2 A-E 15-30 & 0,18 & 2.681 & 1,02 & 497 \\
\hline P2 Bh 290 & 0,42 & 3.481 & 0,70 & 7.605 \\
\hline P3 A $0-15$ & 0,30 & 2.146 & 0,09 & 924 \\
\hline P3 Bh 165-175 & 0,56 & 3.172 & 0,15 & 2.080 \\
\hline P3 Bh 180-183 & 0,47 & 2.912 & 0,29 & 4.168 \\
\hline P3 Bh 210 & 0,64 & 4.840 & 0,16 & 2.189 \\
\hline P3 Bh 280-310 & 1,26 & 7.844 & 0,14 & 1.441 \\
\hline $\mathrm{P} 3 \mathrm{Bh} 335-350$ & 1,00 & 5.399 & 0,09 & 924 \\
\hline P4 A $0-20$ & 0,47 & 2.723 & 0,09 & 547 \\
\hline P4 A $20-30$ & 0,79 & 6.398 & 0,15 & 1.563 \\
\hline P4 A $30-40$ & 0,86 & 11.598 & 0,17 & 2.061 \\
\hline P4 Bh 110-120 & 1,14 & 11.708 & 0,17 & 1.400 \\
\hline P4 Bh 170-180 & 1,56 & 14.897 & 0,09 & 676 \\
\hline P4 Bh-C 270-280 & 1,38 & 13.299 & 0,07 & 434 \\
\hline P4 Bh 370-380 & 2,06 & 24.762 & 0,20 & 1.402 \\
\hline P4 Bh-C 380-390 & 2,31 & 21.773 & 0,21 & 1.640 \\
\hline
\end{tabular}

$I_{450 \mathrm{~nm}} / I_{370 \mathrm{~nm}}$ : índice de humificação proposto por Kalbitz et al. (1999) e $A_{465 \mathrm{~nm}}$ : índice de humifiação proposto por Milori et al. (2002).

Fonte: Autoria própria.

A fração de ácido fúlvico do Espodossolo hidromórfico P1, observou-se que os índices de humificação aumentaram com o decorrer da profundidade, e o maior valor obtido foi no horizonte P1 Bh-C 240 para metodologias proposta por Kalbitz et al. (1999) e Milori et al. (2002). Nas amostras dos ácidos fúlvicos do Espodossolo P2, verifica-se comportamentos distintos entre as duas metodologias empregadas, as quais na determinação empregando Kalbitz et al. (1999), o maior valor encontrado foi no horizonte P2 A-E 15-30, enquanto que para Milori et al. (2002) o maior valor foi no horizonte P2 Bh 290. Comportamento semelhante foi observado nas amostras de ácido fúlvico do Espodossolo bem drenado (P4), em que não houve uma semelhança de comportamento nos valores obtidos empregando as 
duas metodologias, apenas destaca-se que os menores valores do índice de humificação nesse solo para essa fração húmica foram horizontes superficiais, P4 A 0-20 e P4 A 30-40. Enquanto que para as amostras de ácido fúlvico do Espodossolo hidromórfico (P3), observouse que os valores dos índices de humificação foram menores nos horizontes superficial e no mais profundo, enquanto que os maiores valores obtidos para os índices proposto por Kalbitz et al. (1999) e Milori et al. (2002), foram nos horizontes Bh (P3 Bh 180-183).

A partir dos valores dos índices de humificação exibido na Tabela 5.II.13, foram realizadas as correlações com duas metodologias para as amostras de ácido húmico e ácido fúlvico, conforme apresentado na Figura 5.II.31.

Figura 5.II.31: Gráfico de correlação dos índices de humificação das amostras de (a) ácido húmico e (b) ácido fúlvico empregando as metodologias Milori et al., 2002 ( $\left.\mathrm{A}_{465 \mathrm{~nm}}\right)$ e Kalbitz et al., $1999\left(\mathrm{I}_{450 \mathrm{~nm}} / \mathrm{I}_{370 \mathrm{~nm}}\right)$.
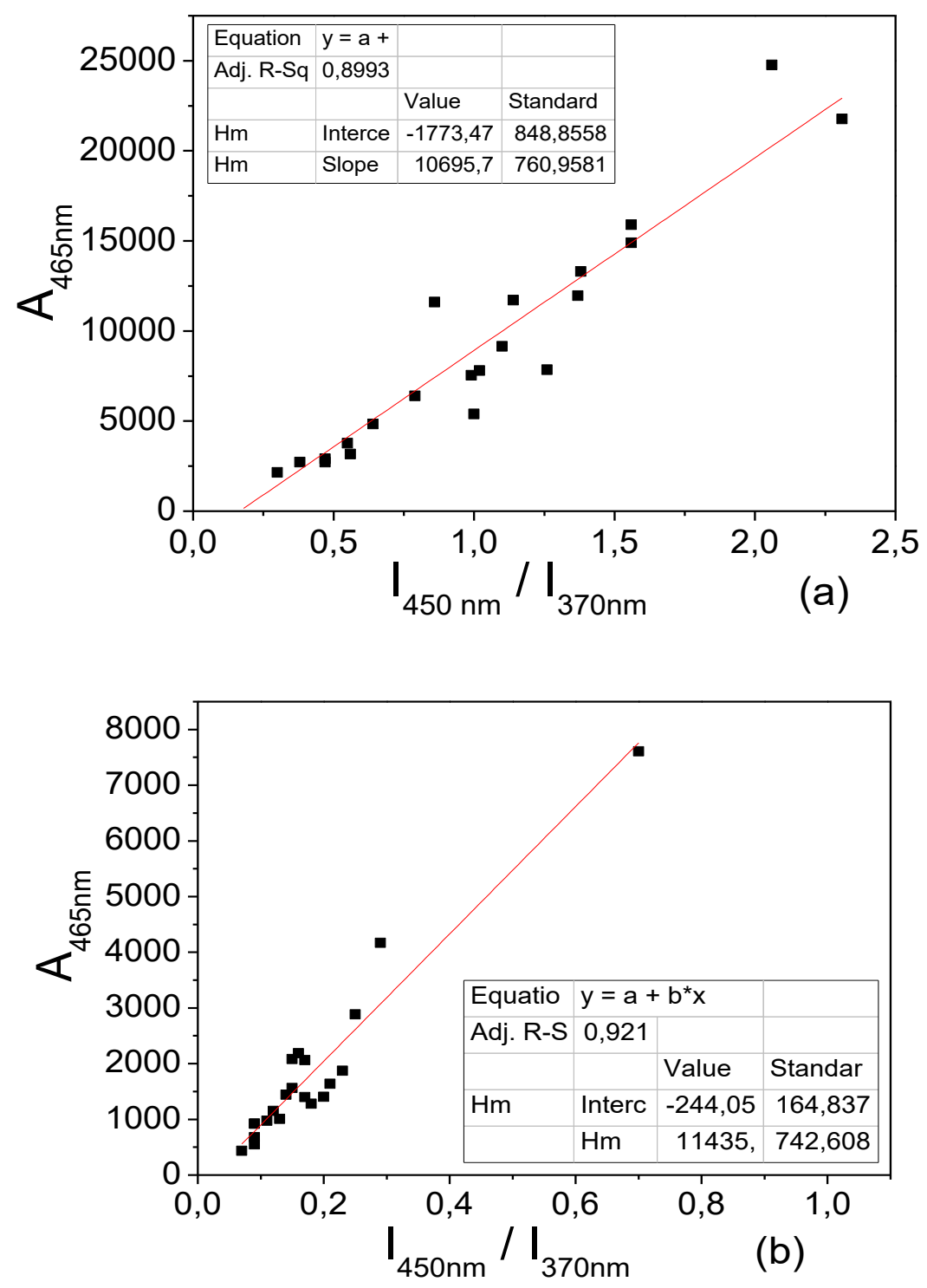

Fonte: Autoria própria. 
Na Figura 5.II.31, pode-se observar que houve uma correlação de moderada a forte para as amostras de ácido húmicos e fúlvicos, com coeficientes de correlação $R=0,89$ e 0,92 respectivamente. Assim, os resultados obtidos pela correlação demonstraram que as metodologias proposta por Kalbitz et al. (1999) e Milori et al. (2002) foram eficientes, visto que há uma correlação forte entre si, as quais demonstraram que a humificação de maneira geral aumenta com o decorrer da profundidade para os quatros Espodossolos Amazônico analisado.

Foi realizado um estudo de correlação entre o índice de humificação $\left(\mathrm{A}_{465 \mathrm{~nm}}\right)$ dos ácidos húmicos em relação à datação do solo inteiro das amostras dos Espodossolos P1, P3 e P4, conforme a Figura 5.II.32. O mesmo estudo foi realizado com o solo inteiro, conforme foi apresentado no item 5.I.2. (Página 67 e 68). Esses resultados foram apresentados em um artigo está publicado na Science of the Total Environmental (STOTEN, Anexo F, página 168).

Figura 5.II..32: Valores de $\mathrm{A}_{465 \mathrm{~nm}}$ dos ácidos húmicos em função da datação de carbono dos Espodossolos P1, P3 e P4.

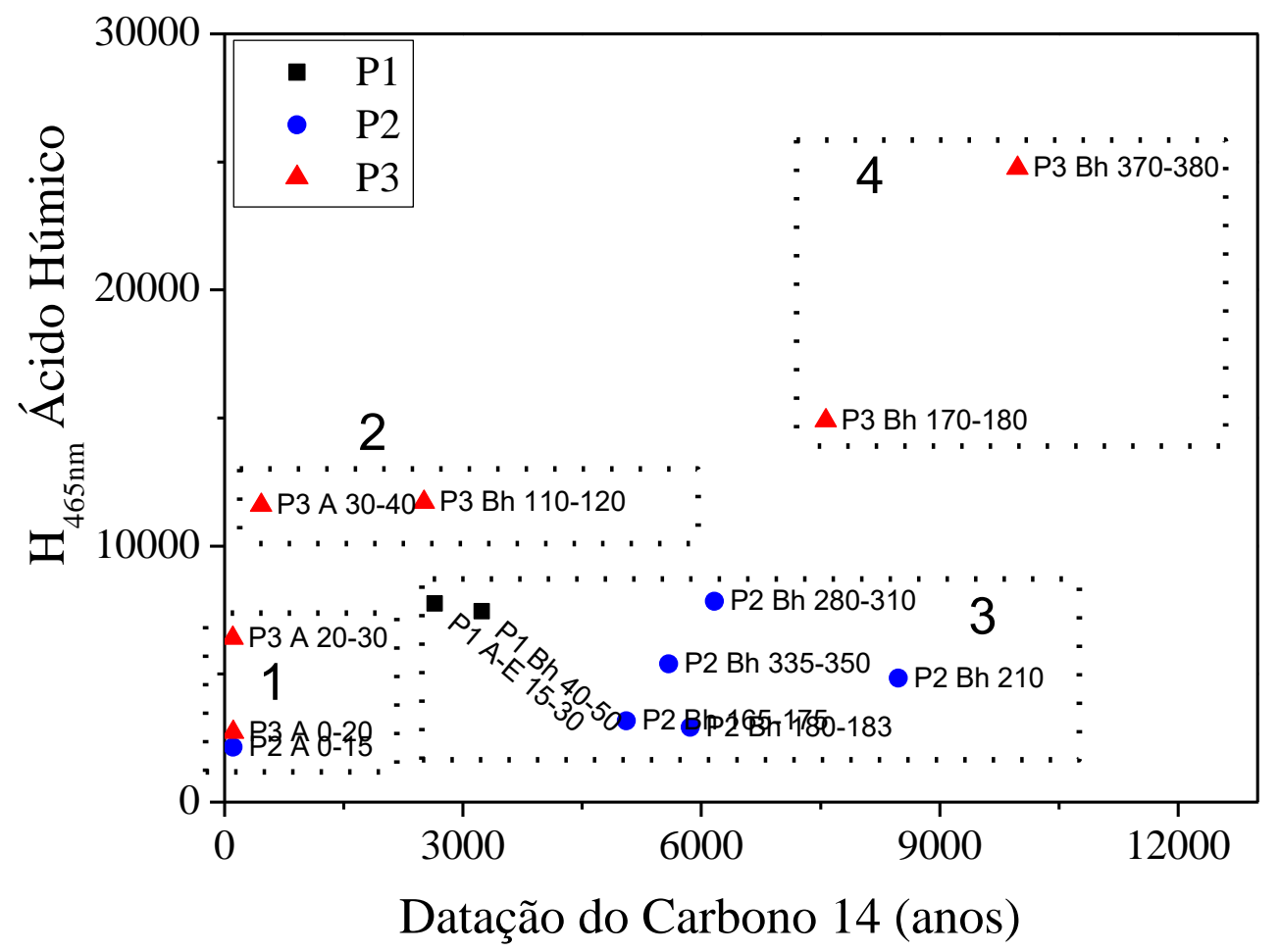

Fonte: Autoria Própria (Artigo Tadini et al. 2018, Anexo F, página 168). 
Os resultados apresentado na Figura 5.II.32, foram semelhantes ao apresentado na Figura 5.I.12, em que há observação de quatro grupos. Esses resultados sugerem que o MOS nos horizontes de superfície inclui compostos simples e lábeis e $\mathrm{AH}$ pouco humificado, ao passo que os compostos humificados mais complexos são lixiviados e acumulados ou retidos em horizontes mais profundos enquanto a molécula pequena e menos condensada é

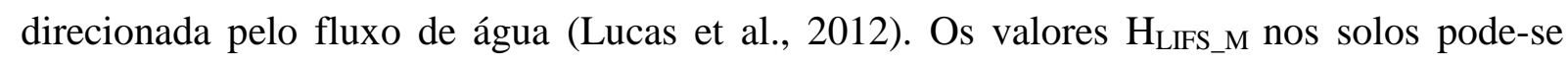
observar a contribuição direta do ácido húmico porque tem o mesmo comportamento em relação aos solos inteiros, como mostra o grupo 3 (Figura 5.II.32, especialmente para os solos P1 e P4). Em outros grupos (1, 2 e 4) (Figura 5.I.12), seu comportamento pode ser influenciado pelas outras frações, como ácidos fúlvicos e humina, que apresentam um índice de humificação diferente (HLIF__M $)$. Confirmando assim, que existem quatro tipos de matéria orgânica: - humificada, recalcitrante e antiga; - lábil e jovem; - pouco humificada e antiga; humificada e jovem. Isso permite inferir que o processo de humificação não tem relação direta com a datação do material orgânico, bem com de suas frações húmicas. Além disso, no terceiro grupo das amostras de ácido húmico em que há presença de um carbono mais antigo do que na superfície, levantamos a hipótese que esse carbono deva estar associado à presença de composto com poucas modificações estruturais, tais como derivados de lignina.

A acumulação de material mais humificado foi hipótese de estar associada à presença de estruturas contendo lignina e derivados de lignina para o terceiro grupo. Assim, um experimento exploratório foi realizado pela adição de quantidades controladas de lignina à amostra de Espodossolo que apresentou o maior índice de humificação, isto é, P3 Bh-C 270280. O valor do índice de humificação $\mathrm{H}_{\text {LIFS_M }}$ da amostra P3 Bh-C 270-280 diminuiu com o aumento das adições de lignina. Em particular, o valor HLIFS_M $_{\text {da }}$ amostra com 1, 5 e $10 \%$ de lignina relacionada à massa de pelota (massa do solo $400 \mathrm{mg}$ ) apresentou valores aproximados de 19.798, 6.279 e 2.740, respectivamente. Além disso, a determinação do índice de humificação $\mathrm{A}_{465 \mathrm{~nm}}$ de uma solução de lignina foi realizado, conforme observado na Figura 5.II.33. O resultado sugere que os ácidos húmicos presentes nos horizontes $\mathrm{Bh}$, como P1 Bh-C 240, P1 Bh-C 260, P1 C 350, P3 Bh 170-180 e P3 Bh-C 270-280, obtiveram valores de $\mathrm{A}_{465 \mathrm{~nm}}$ muito semelhantes ao $\mathrm{A}_{465 \mathrm{~nm}}$ da lignina. Portanto, sugerindo que existe uma influência da lignina na composição de ácidos húmicos, uma vez que ambos têm a mesma intensidade de fluorescência $(512 \mathrm{~nm})$ conforme observado na Figura 5.II.33. Os ácidos húmicos têm fluorescência mais intensa quando comparados com a lignina, o que pode ser explicado com o fato de que o ácido húmico possui mais compostos, como grupos carboxílicos, fenóis e aminas. Esse estudo foi apresentado no artigo sob revisão na Science of 
the Total Environment (Tadini et al. 2018, Anexo F, página 168) que mostra por meio da humificação do solo inteiro e dos ácidos húmicos, que dos ácidos húmicos extraídos desses solos podem ser originados de derivados de lignina.

Figura 5.II.33: Espectro de Emissão de Fluorescência de uma solução de $3 \mathrm{mg} \mathrm{L}^{-1}$ de lignina e ácido húmico de $12,5 \mathrm{mg} \mathrm{L}^{-1}$ (amostra utilizada foi: P1 Bh-C 240).

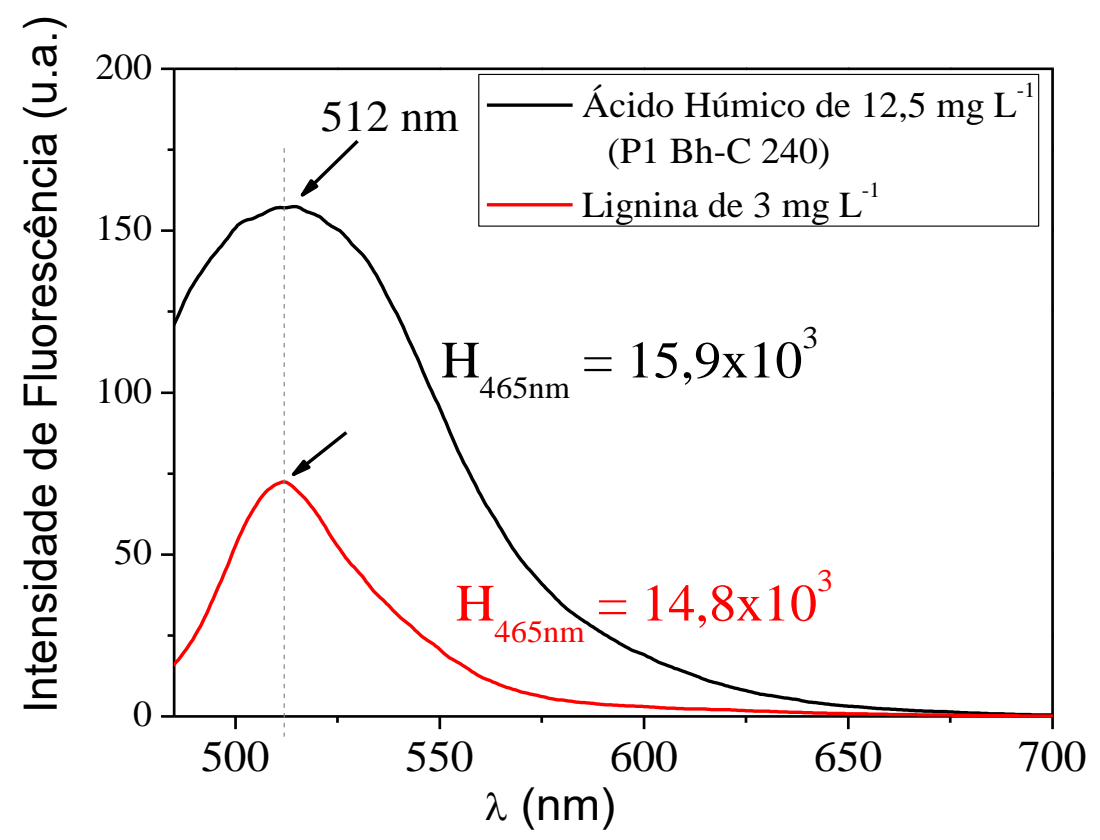

Fonte: Autoria Própria (Artigo Tadini et al. 2018, Anexo F, página 168).

\section{II.3.2. Matriz Emissão Excitação (EEM - 3D)}

A Figura 5.II.34 mostra os espectros obtidos pela Fluorescência na modalidade Matriz Emissão-Excitação (MEE) das amostras de ácido húmico extraído do Espodossolo Hidromórfico (P1). Os demais espectros dos Espodossolos P2, P3 e P4 encontram-se em Anexo F, nas Figuras 5.II.37, 5.II.40 e 5.II.43 (Anexo E, páginas 162 a 165).

A Figura 5.II.34 exibe os espectros das frações de ácidos húmicos do Espodossolo hidromórfico (P1), cuja emissão foi de 450-485 nm e excitação entre 250-275 nm, com as intensidades de fluorescência aumentando com o decorrer da profunidade, destacando-se os horizontes: P1 Bh 40-50, P1 Bh-C 240 e P1 C 350. Esse comprimento de onda com emissão na região do vermelho caracteriza compostos com estruturas complexas, as quais estão presentes ligações do tipo $\mathrm{C}=\mathrm{C}$ presente em anéis aromáticos (Valencia et al. 2013; Wei et al. 2014). 
Figura 5.II.34: Espectros na modalidade emissão-excitação das amostras de ácido húmico do Espodossolo Hidromórfico (P1) para as diferentes profundidades: (a) P1 A 0-15, (b) P1 A-E 15-30, (c) P1 Bh 40-50, (d) P1 Bh-C 240, (e) P1 Bh-C 260 e (f) P1 C 350.
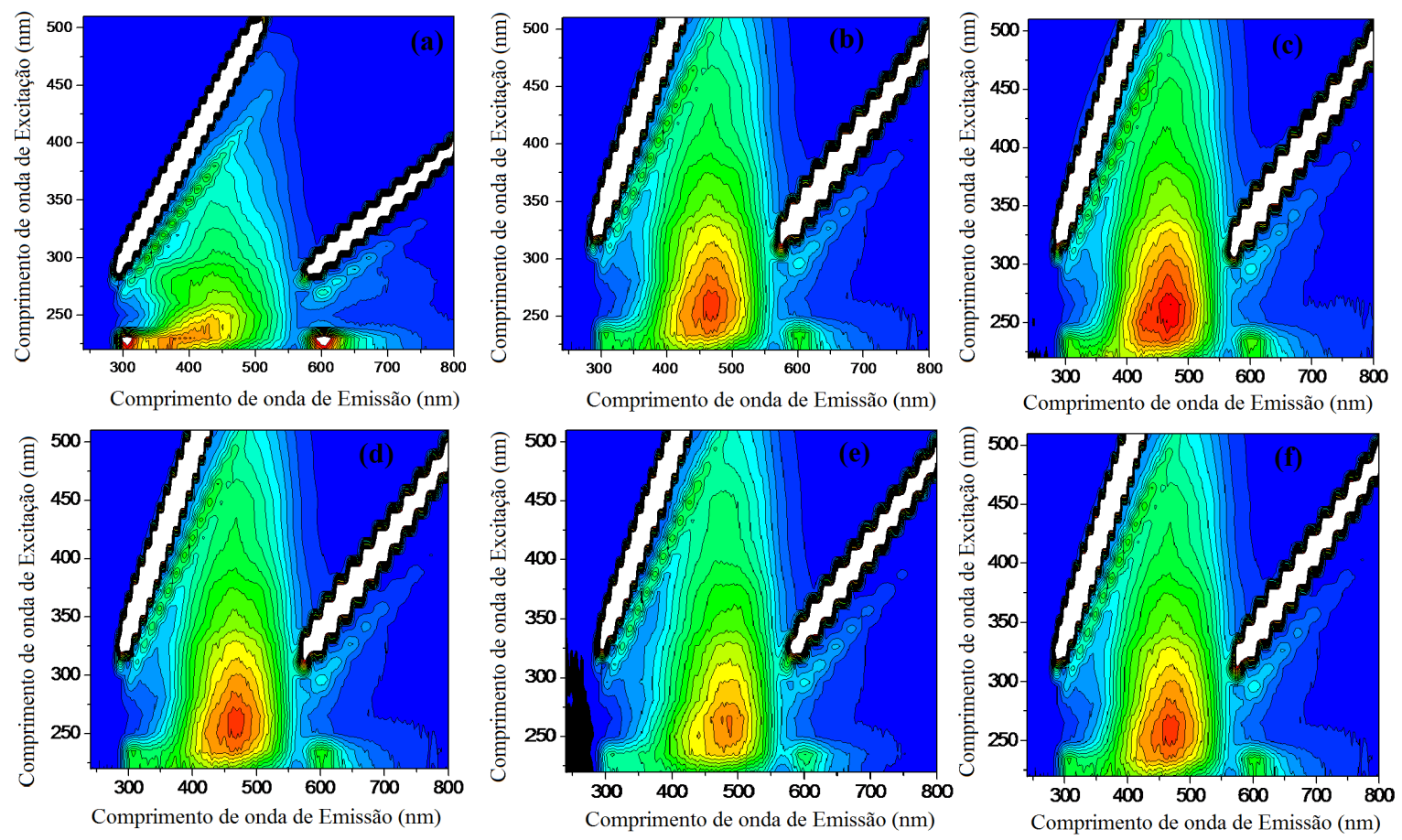

Fonte: Autoria Própria.

De maneira geral, os demais Espodossolos hidromórficos P2 e P3 apresentaram espectros de MEE semelhantes ao mostrado na Figura 5.II.34, cuja intensidade máxima de emissão variou de 350-370nm e excitação de 240-250 nm, sendo que intensidade de fluorescência aumentou com o decorrer da profundidade e os maiores picos foram observados nos horizontes P2 A-E 15-30 e P3 Bh 180-183 (Anexo E, páginas 163 a 166, Figuras 5.II.37 e 5.II.40, respectivamente). Enquanto que para o Espodossolo bem drenado P4 para essa fração de ácido húmico, pode-se observar um deslocamento na intensidade de emissão de fluorescência para comprimentos de onda maiores com o decorrer da profundidade nesse solo. Os picos de intensidade de fluorescência foram de $\lambda_{\text {excitação }} / \lambda_{\text {emissão }}: 240-250 \mathrm{~nm} / 400-50 \mathrm{~nm}$, cujo deslocamento sendo verificado nos comprimentos de onda de emissão com o decorrer da profundidade do solo, e as maiores intensidades obtidas nos horizontes $\mathrm{Bh}$ intermediários e mais profundos, tais como: P4 Bh 110-120, P4 Bh 170-180 e P4 Bh-C 380-390, respectivamente (Figura 5.II.43, sessão Anexo E, páginas 162 a 165).

A Figura 5.II.35 mostra os espectros obtidos pela Fluorescência na modalidade MEE das amostras de ácido fúlvico extraído do Espodossolo Hidromórfico (P1), cujos demais 
espectros dos Espodossolos P2, P3 e P4 encontram-se na sessão Anexo E, páginas 166 a 169, nas Figuras 5.II.38, 5.II.41 e 5.II.44.

A Figura 5.II.35 exibe os espectros das frações de ácidos fúlvicos do Espodossolo hidromórfico (P1), cuja emissão foi de 400-450 nm, e a formação de dois picos de excitação entre 240-250 nm e 350-375 nm, com as intensidades de fluorescência aumentando com o decorrer da profunidade até os horizontes P1 Bh 40-50 e P1 Bh-C 240. Ao reportar na literatura, tais picos na região mais próxima ao azul, refere-se a estruturas mais simples, como cadeias alifáticas e grupos carboxílicos. Comportamento semelhante foi verificado para o Espodossolo hidromórfico P2 (Figura 5.II.41, sessão Anexo E, páginas 162 a 165), em que os picos de emissão de fluorescência foram em comprimentos de onda menores, mais para a região do azul como observado no Espodossolo hidromórfico P1, cuja maior intensidade foi no horizonte Bh, P2 Bh 290.

Figura 5.II.35: Espectros na modalidade emissão-excitação das amostras de ácido fúlvico do Espodossolo Hidromórfico (P1) de diferentes profundidades: (a) P1 A 0-15, (b) P1 A-E 15-30, (c) P1 Bh 40-50, (d) P1 Bh-C 240, (e) P1 Bh-C 260 e (f) P1 C 350.

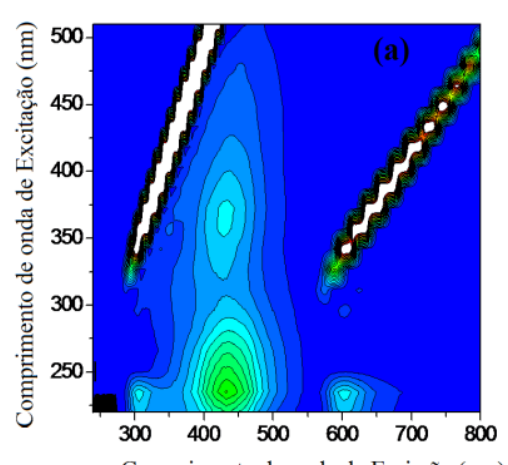

Comprimento de onda de Emissão (nm)
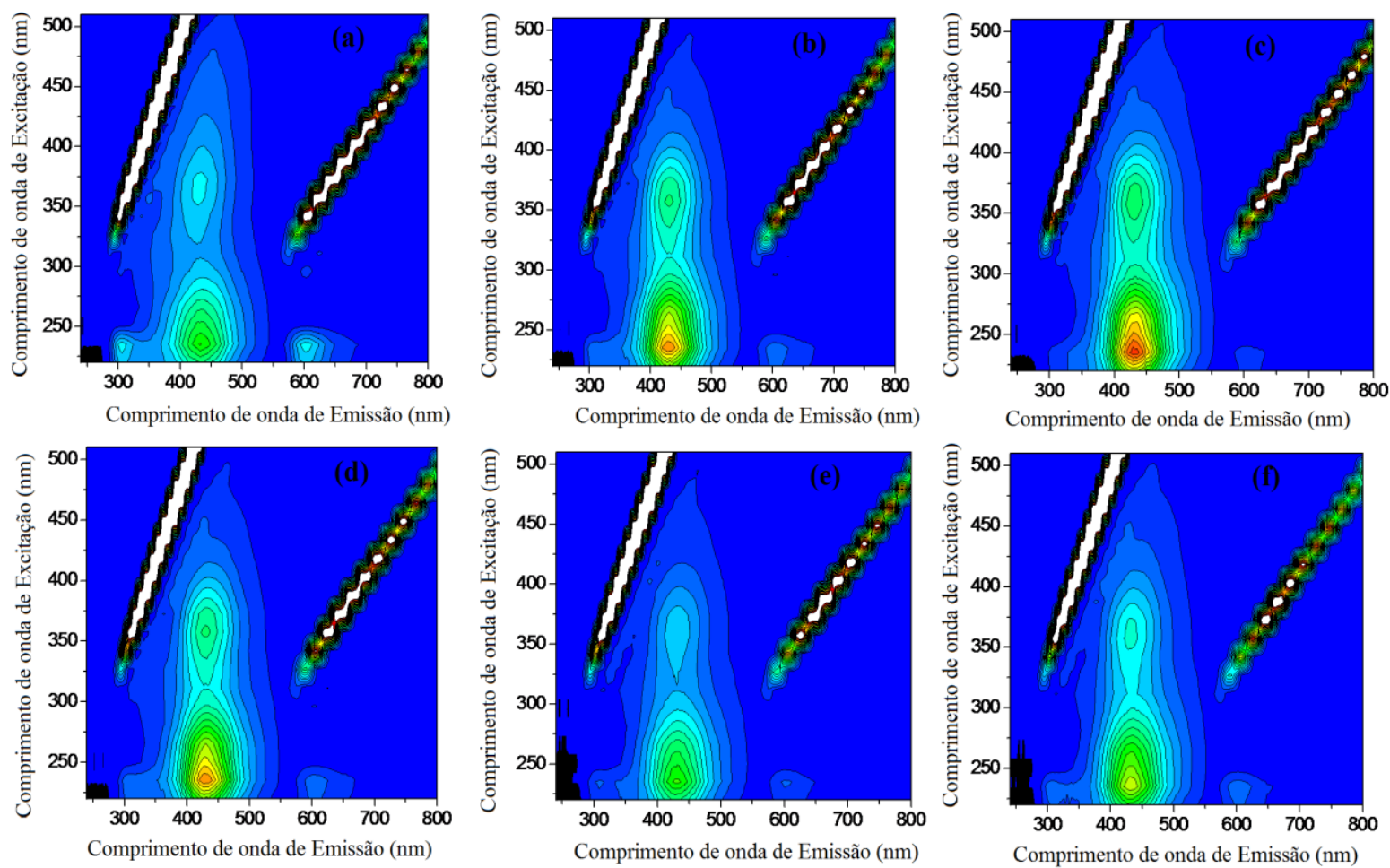
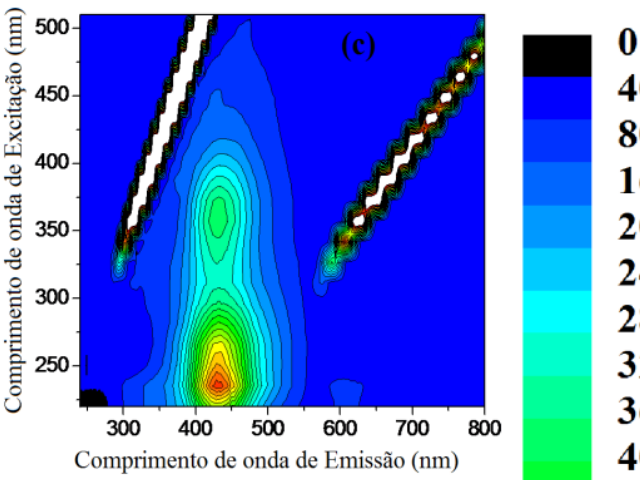

Fonte: Autoria Própria.

Nos demais Espodossolos, P3 e P4, observou-se intensidade de emissão de fluorescência para comprimentos de onda maiores, na região do vermelho para fração ácido 
fúlvico desses solos, em que os picos variaram de 240-250 nm excitação e 400-425 nm emissão e a formação de um segundo pico de excitação de 350-375 nm, sendo as maiores intensidade observadas nos horizontes Bh e A, P3 Bh 210 e P4 A 20-30, respectivamente (Figuras 5.II.41 e 5.II.44, sessão Anexo E, páginas 162 a 165).

A Figura 5.II.36 mostra os espectros obtidos pela Fluorescência no modo MEE realizado em pastilhas de amostras sólidas das frações humina do Espodossolo hidromórfico (P1), cujos demais espectros dos Espodossolos P2, P3 e P4 encontram-se na Sessão Anexo E (páginas 162 a 165), nas Figuras 5.II.39, 5.II.42 e 5.II.45.

Figura 5.II.36: Espectros na modalidade emissão-excitação das amostras de humina do Espodossolo Hidromórfico (P1) de diferentes profundidades: (a) P1 A 0-15, (b) P1 A-E 15-30, (c) P1 Bh 40-50, (d) P1 Bh-C 240, (e) P1 Bh-C 260 e (f) P1 C 350.
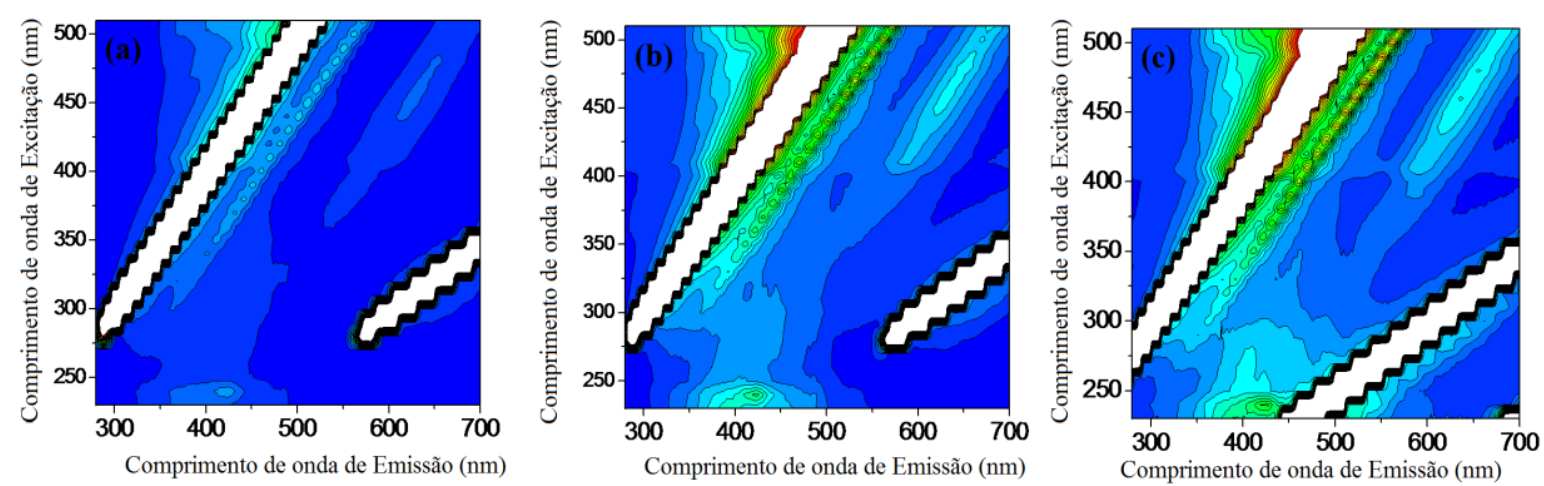

0

40

80

160

200

240

280

320

360

400
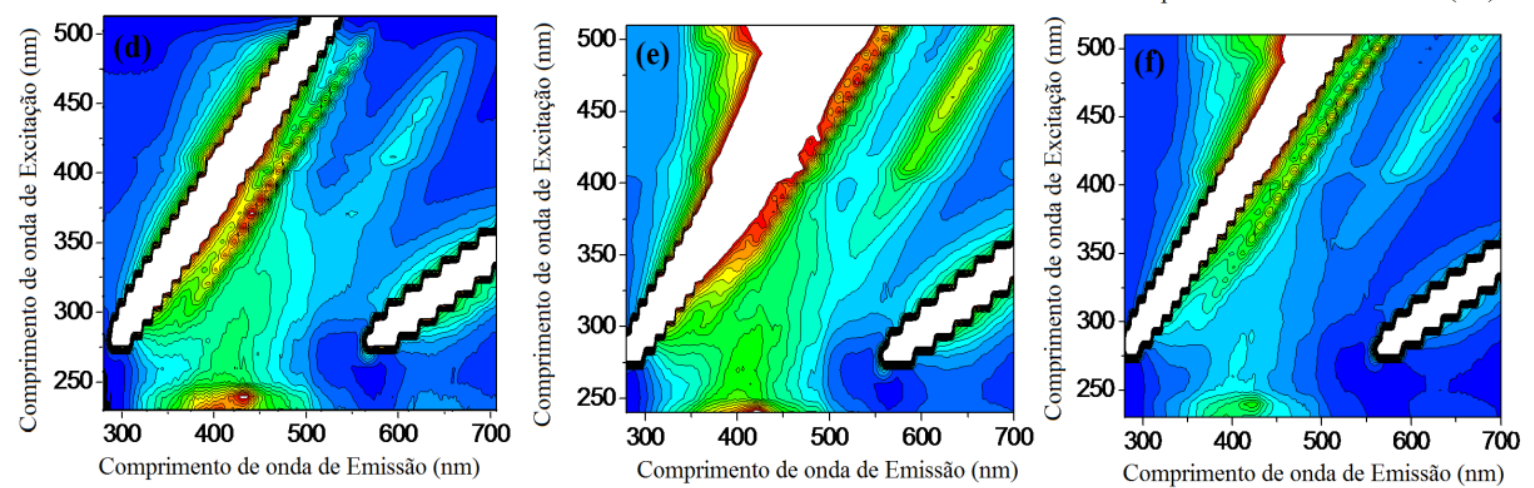

440

480

520

560

600

640

680

720

760

800

Fonte: Autoria Própria.

A Figura 5.II.36 exibe os espectros das frações de humina do Espodossolo hidromórfico (P1), cuja emissão foi de $425 \mathrm{~nm}$ e excitação entre 240-250 nm, com as intensidades de fluorescência aumentando com o decorrer da profunidade até os horizontes P1 Bh-C 240 e P1 Bh-C 260. Ao reportar na literatura, não há estudos de fluorescência no estado sólido envolvendo a fração humina, este trabalho rendeu um artigo publicado no Science of Total Environmental Science em 2015 (Tadini et al. 2015, Anexo F, página 166). Deste modo, 
esse estudo demonstra a importância de estudar essa fração húmica que representa em termos de massa a maior parcela das frações húmicas da matéria orgânica no solo.

De maneira geral, os demais Espodossolos P2, P3 e P4, obtiveram comportamentos semelhantes, com comprimento de ondas de excitação que variaram de 240-260 nm e emissão de 300-410 nm, sendo observado um aumento desses picos com o decorrer da profundidade do solo, destacando-se os horizontes, P2 Bh 290, P3 Bh 210, P4 A 20-30, P4 Bh 170-180 e P4 Bh-C 270-280, que obtiveram os maiores picos de intensidade de fluorescência da fração humina.

Os espectros de fluorescência na modalidade matriz emissão-excitação das frações húmicas (ácidos húmicos, ácidos fúlvicos e humina), foram tratados empregando o método matemático denominado, Análise de Fatores Paralelos (CP/PARAFAC). Assim, nas amostras de ácido húmico extraídos dos quatros Espodossolos Amazônico, observou-se a contribuição de duas componentes que foram responsáveis pela fluorescência nessa fração húmica, conforme exibido na Figura 5.II.46, cujo diagnóstico de consistência de tensor de core (concordia) foi de $94,67 \%$.

Figura 5.II.46: Representação dos Componentes obtidos pelo PARAFAC: CI (a) e CII (b) presentes nos extratos de ácidos húmicos extraídos dos quatros Espodossolos Amazônico.
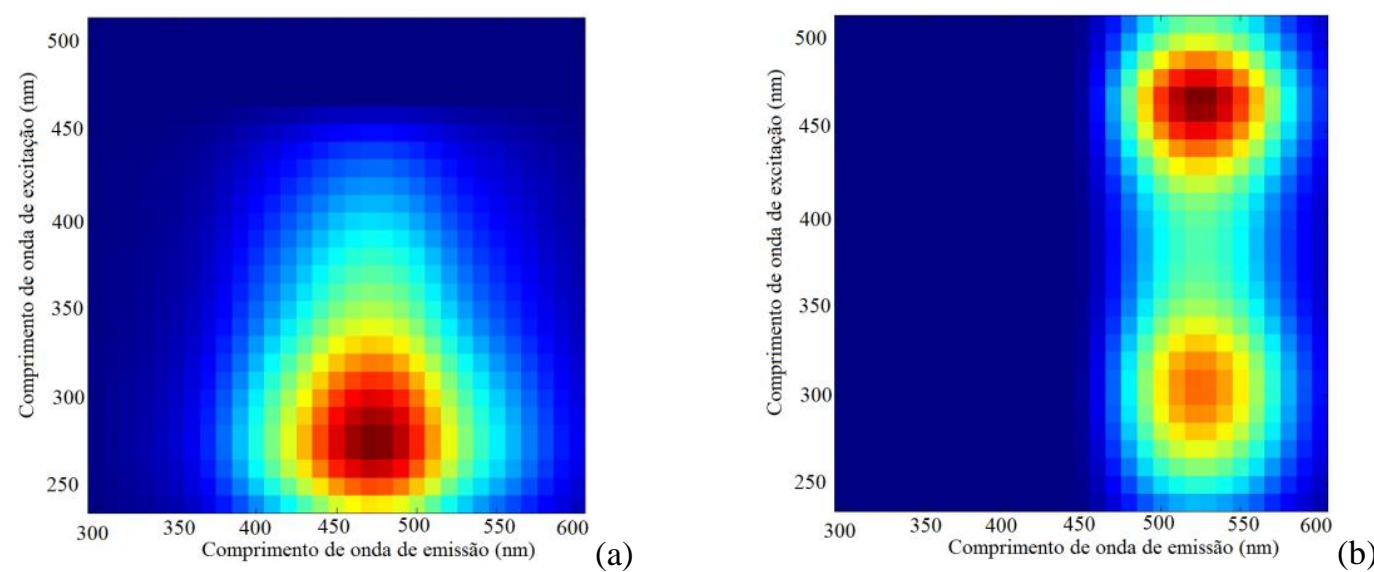

Fonte: Autoria Própria.

Na Figura 5.II.46, pode-se observar que o CI ( $\left.\lambda_{\mathrm{ex}} / \lambda_{\mathrm{em}}: 275-320 / 460 \mathrm{~nm}\right)$, refere-se ao pico A, o qual apresenta baixa energia e são conhecidos por ser tipicamente de ácido húmico terrestre (Coble, 1996; Matthews et al., 1996; Stedmon et al., 2003; Coble et al., 2014). Enquanto que o CII apresentou dois picos de excitação $\left(\lambda_{\text {ex }} / \lambda_{\text {em }}: 300 / 525 \mathrm{~nm}\right.$ e $\lambda_{\text {ex }} / \lambda_{\text {em }}$ : $455 / 525 \mathrm{~nm}$ ) referindo-se a um caráter com estruturas mais complexas, uma vez que a 
excitação foi em comprimentos de onda maiores na região do vermelho, e o pico $\lambda_{\mathrm{ex}} / \lambda_{\mathrm{em}}$ : 455/525nm, atribui-se ao Pico E, presente em ácido fúlvico de solo (Stedmon et al., 2003; Coble et al., 2014).

Segundo Lumb (1978), qualquer molécula que contém elétrons $\pi$ deslocalizados tem chance de serem fluorescentes como polienos, e hidrogenos carbonos aromáticos. A molécula de benzeno tem uma eficiência quântica baixa e um tempo de vida de 29 nanosegundo, se substituir um grupo metil no benzeno, originando a molécula de touleno, a eficiência quântica aumenta. Assim, à medida que os grupos alquilos se tornam maiores, a mudança para comprimentos de onda mais longos torna-se progressivamente menor em comparação com o efeito de substituição de grupos alquilo adicionais em outras posições no anel. Deste modo, aumentando o tamanho do grupo alquilo produz uma pequena mudança para comprimentos de onda mais longos. Outro fator importante mencionado por Lumb (1978), é que a maioria dos compostos alifáticos não é luminescente ou emitem em comprimentos de onda menores.

A Figura 5.II.47 mostra a razão Componente II/Componente I das amostras de ácido húmico com o decorrer da profundidade para os quatros Espodossolos Amazônico. Pode-se observar que os Espodossolos hidromórficos P1 e P2, há pouca variação da razão da CII/CI com o decorrer da profundidade para esses solos, permitindo inferir que uma mesma estrutura para esses dois Espodossolos hidromórficos. Assim, nesses dois Espodossolos, verifica-se que há uma mistura de estruturas com características mais simples e complexas.

Nos Espodossolo hidromórfico P3 e Espodossolo bem drenado P4, observou-se que a razão CII/CI é menor nos horizontes superficiais e aumenta com o decorrer da profundidade, verificando assim, uma maior variação com o perfil do solo. Deste modo, pode-se inferir que há um aumento da estrutura com características mais complexas (Componente II) com o decorrer da profundidade, podendo-se associar a um aumento no índice de humificação, conforme observado pela razão $\mathrm{C} / \mathrm{N}$ e a presença de grupamentos mais aromáticos pelo FTIR. 
Figura 5.II.47: Razão ComponenteII/ComponenteI das amostras de ácido húmico dos quatros Espodossolos Amazônico com o decorrer da profundidade.

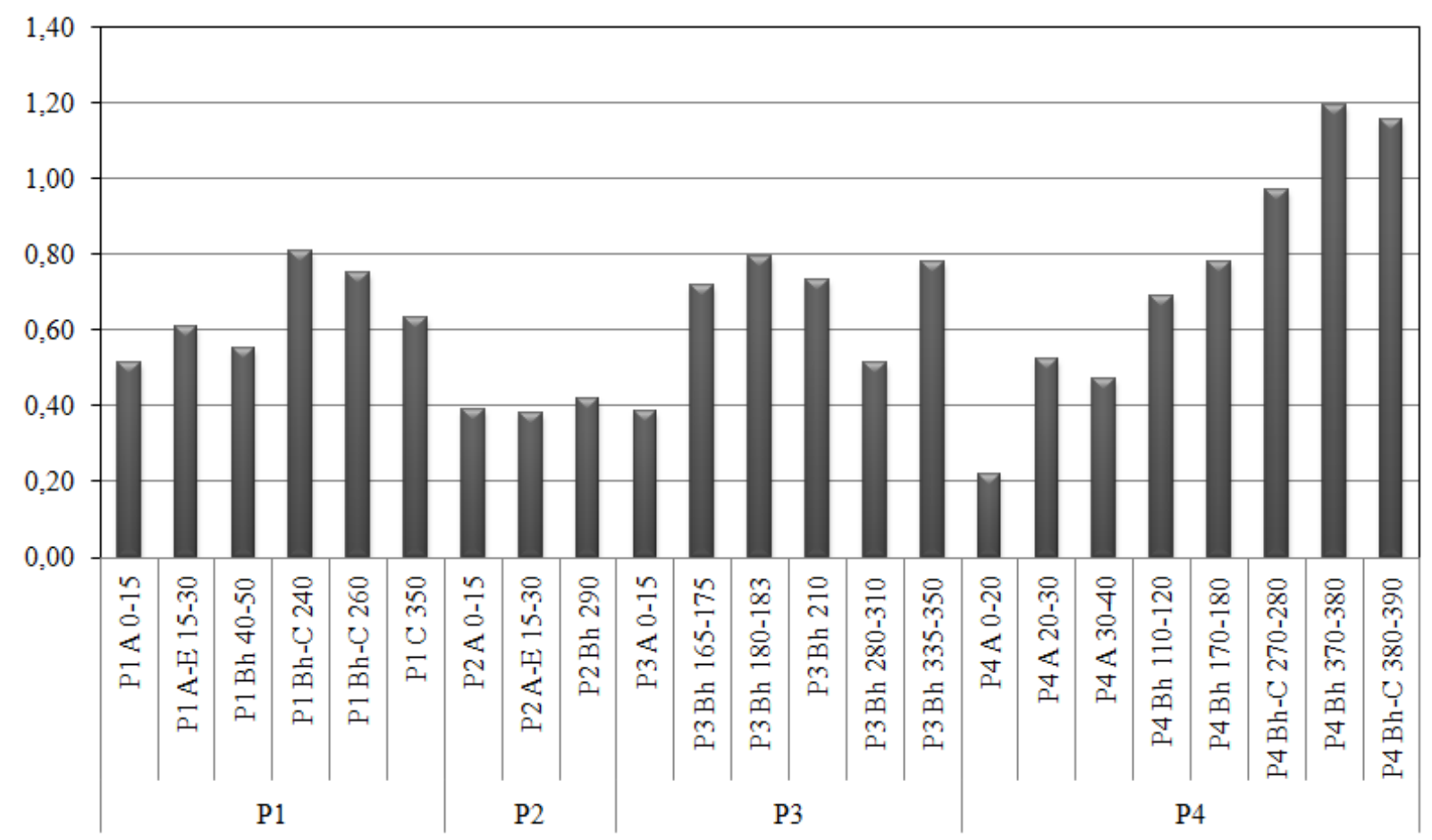

Fonte: Autoria Própria.

As amostras de Ácido Fúlvico para os quatros Espodossolos Amazônico foram possíveis verificar a contribuição de duas Componentes, conforme apresentado na Figura 5.II.48 com um concordia de $97,32 \%$.

Figura 5.II.48: Representação dos Componentes: CI (a) e CII (b) presentes nos extratos de ácido fúlvico extraídos dos quatros Espodossolos Amazônico.
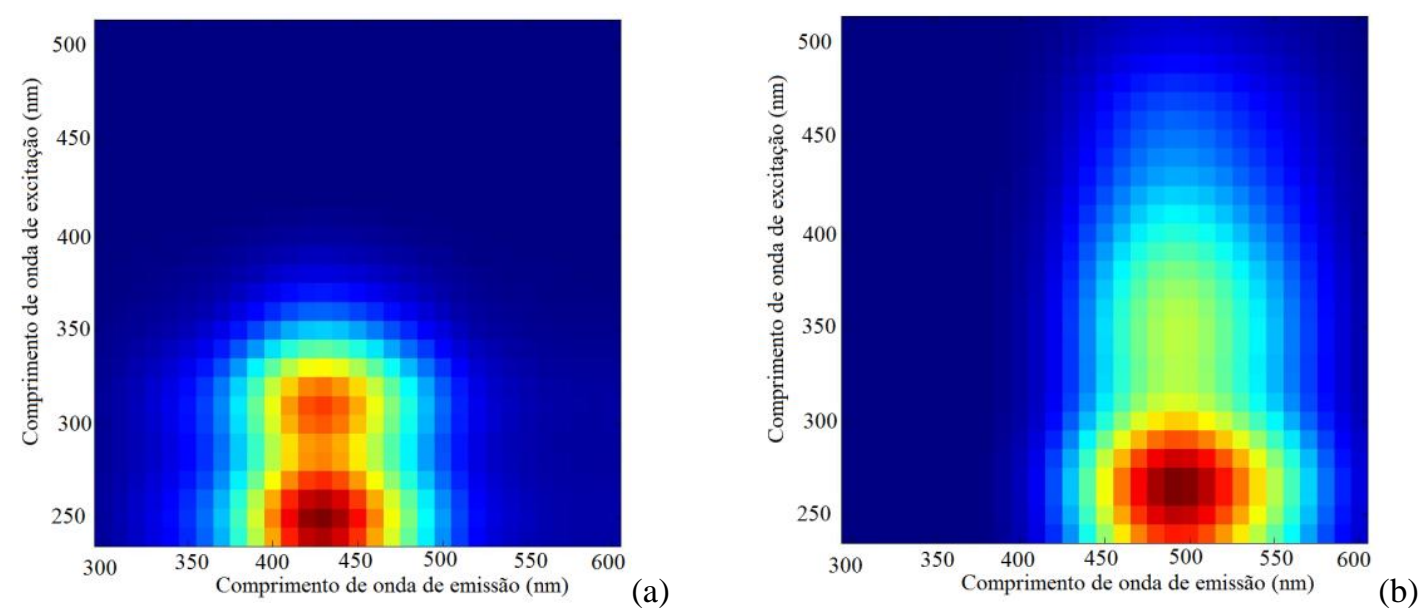

Fonte: Autoria Própria. 
O Componente I ( $\lambda_{\text {ex }} / \lambda_{\text {em }}: 260 / 400-460 \mathrm{~nm}$ e $\left.\lambda_{\text {ex }} / \lambda_{\text {em }}: 320-360 / 400-460 \mathrm{~nm}\right)$, referem-se aos picos A e C, que são característicos de $\mathrm{SH}$ provenientes de ambientes terrestres, sendo o pico A, tipicamente húmico, e o pico C, tipicamente fúlvico (Coble, 1996; Matthews et al., 1996; Stedmon et al., 2003; Coble et al., 2014). Enquanto que o Componente II ( $\lambda_{\text {ex }} / \lambda_{\text {em }}$ : 275/500 nm), refere-se ao pico D, e atribuí-se a ácidos fúlvicos de solos (Stedmon et al., 2003; Coble et al., 2014).

A Figura 5.II.49 exibe a razão da Componente II/Componente I das amostras de ácido fúlvico dos Espodossolos Amazônico. Pode-se observar que nos Espodossolos hidromórfico e bem drenado, $\mathrm{P} 2$ e $\mathrm{P} 4$, respectivamente, não há variação significativa entre a razão CII/CI, o que permite inferir que há uma continuidade na estrutura dessa fração nesses solos, ou seja, trata-se de uma mesma estrutura com o decorrer do perfil para esses dois Espodossolos. O mesmo comportamento foi observado para as amostras de ácido fúlvico dos Espodossolos hidromórficos P1 e P3, porém nesses dois solos, nos horizontes P1 Bh-C 240, P3 Bh 180-183 e P3 Bh 210, verificou-se uma aumento da razão CII/CI, o que demonstra que nesses horizontes a Componente II varia muito mais que a Componente I, assim, dando características com grupos mais aromáticos na estrutura da fração fúlvica nesses horizontes.

Figura 5.II.49: Razão ComponenteII/ComponenteI das amostras de ácido fúlvico dos quatros Espodossolos Amazônico com o decorrer da profundidade.

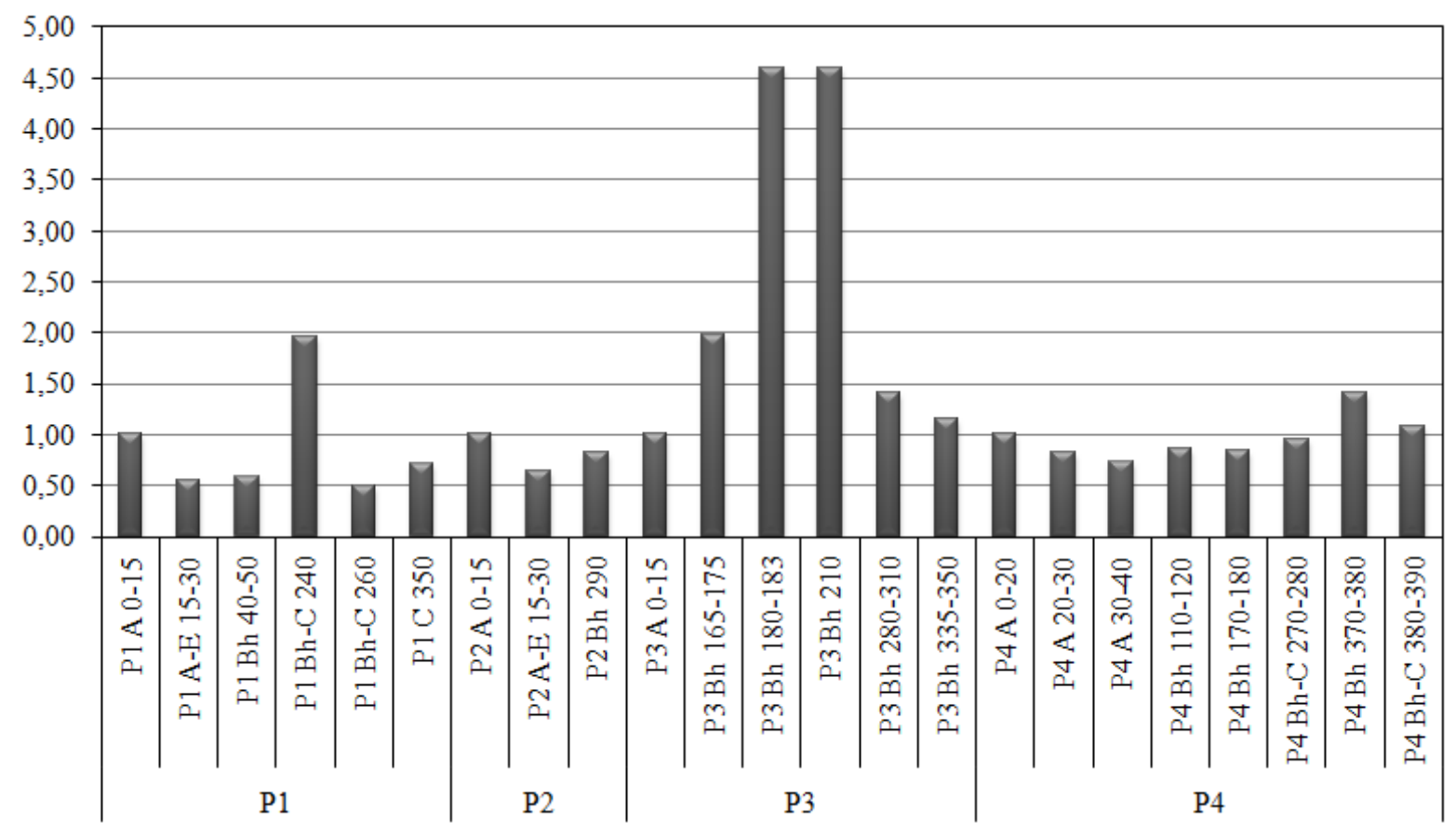

Fonte: Autoria Própria. 
Os espectros de fluorescência das frações huminas também foram tratados pelo CP/PARAFAC, e foi possível observar a contribuição de duas componentes para os quatros Espodossolos Amazônico conforme exibido na Figura 5.II.50, obtendo um concordia de $88,67 \%$.

Figura 5.II.50: Representação dos Componentes: CI (a) e CII (b) presentes nos extratos de humina extraídos dos quatros Espodossolos Amazônico.
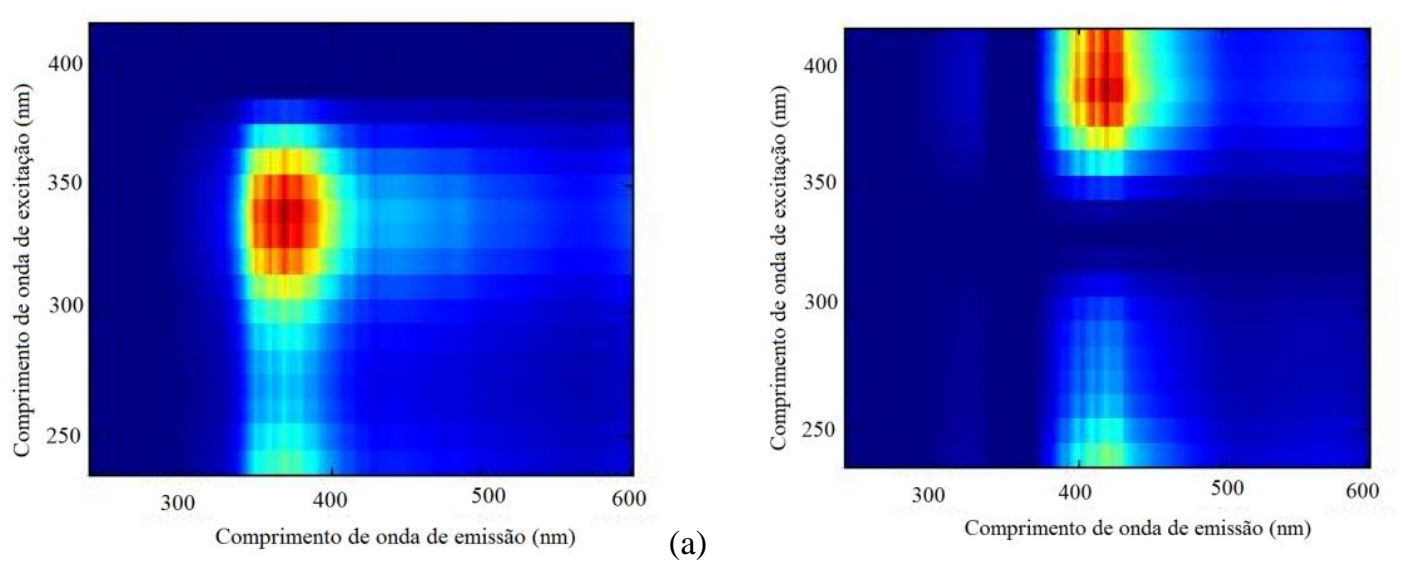

(b)

Fonte: Autoria Própria.

O Componente I ( $\left.\lambda_{\mathrm{ex}} / \lambda_{\mathrm{em}}: 340 / 390 \mathrm{~nm}\right)$ é típico de estruturas mais simples presentes em SH de ambientes terrestres e o Componente II $\left(\lambda_{\mathrm{ex}} / \lambda_{\mathrm{em}}: 390 / 410 \mathrm{~nm}\right)$ são típicos de $\mathrm{AH}$ terrestre e referente ao Pico $\mathrm{C}$, os quais são associados a uma estrutura mais complexa e humificada, com a presença de anéis aromáticos fundidos e/ou combinação de anéis aromáticos simples (Coble, 1996; Matthews et al. 1996). Os resultados obtidos mostraram que houve contribuição de compostos derivados de lignina na estrutura das huminas extraídas de solos da região Amazônica. Assim, demonstrando a importância do estudo dessa fração das substâncias húmicas que atualmente há pouco interesse ambiental.

A Figura 5.II.51 mostra a razão da Componente II/Componente I para as amostras de humina extraída dos Espodossolos Amazônico. Pode-se observar que não há variação significativa da razão CII/CI para os quatros Espodossolos Amazônico para essa fração, podendo inferir que não há variação na estrutura dessa fração com o decorrer do perfil do solo. Destaca-se apenas, os horizontes P1 Bh-C 240 e P3 Bh 210 em que houve uma diminuição da razão CII/CI para esses dois Espodossolos, podendo associar a uma maior presença da Componente II a qual refere-se a uma estrutura mais complexa. 
Figura 5.II.51: Razão Componente II /Componente I das amostras de humina dos quatros Espodossolos Amazônico com o decorrer da profundidade.

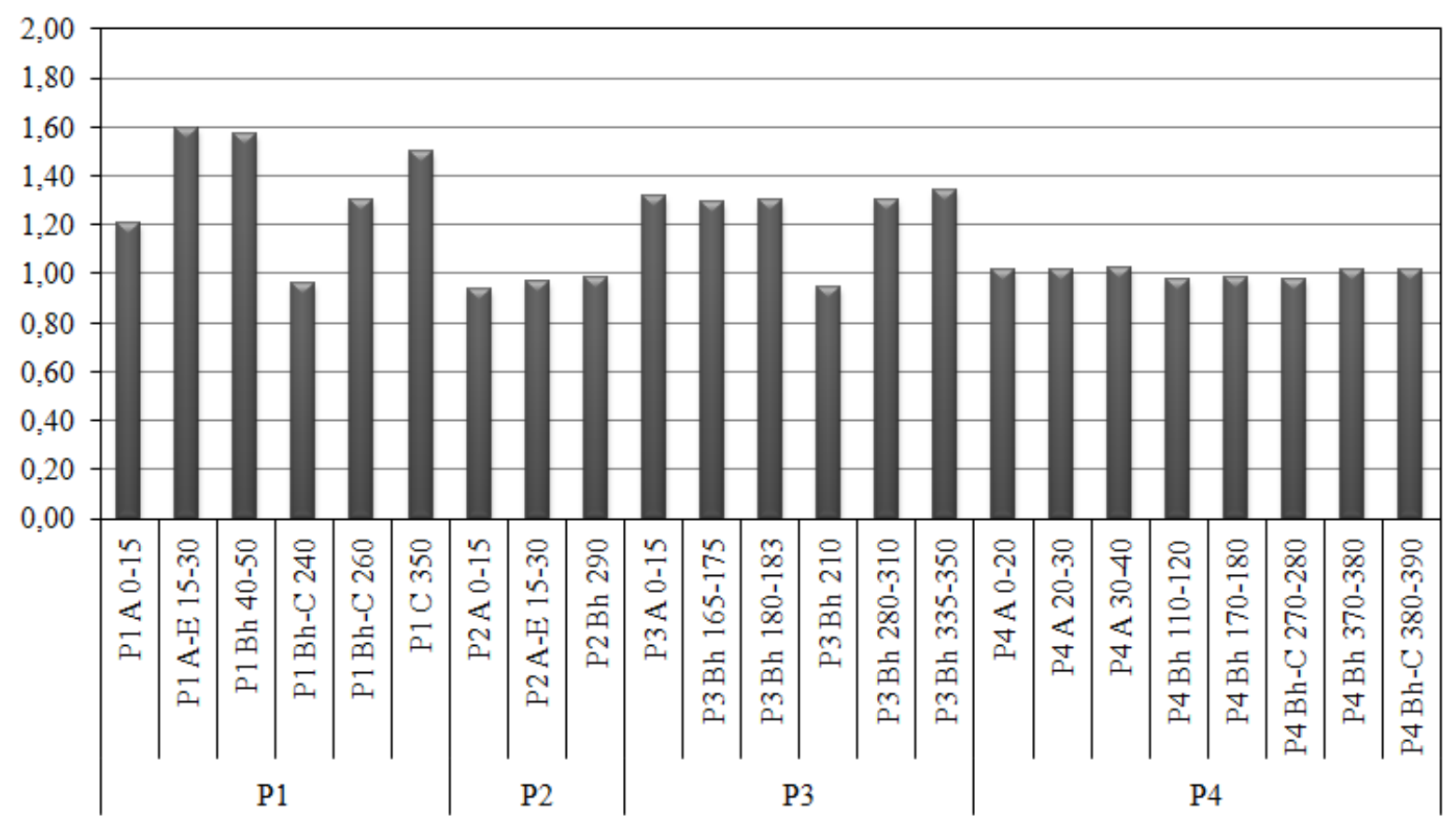

Fonte: Autoria Própria.

\section{II.4. Espectrometria de Absorção Atômica com Atomização por Chama ou Forno}

\section{Grafite}

Para uma melhor compreensão dos dados obtidos do solo inteiro, foi realizada a determinação de metais presentes nas frações húmicas, as quais foram selecionadas nas amostras dos Espodossolo hidromórfico (P1) e Espodossolo bem drenado (P4) conforme apresentado na Tabela 5.II.14. Ressalta-se que foram selecionados alguns metais para esse estudo, dentre os quais se destaca os metais Ferro e Alumínio.

$\mathrm{Na}$ Tabela 5.II.14 verificou-se que as maiores concentrações dos metais Zinco, Ferro e Potássio seguiram a seguinte ordem decrescente: ácido húmico > ácido fúlvico > humina. $\mathrm{O}$ metal Magnésio obteve a seguinte ordem decrescente de concentração: ácido húmico > humina > ácido fúlvico; enquanto que para o metal Alumínio observou-se um comportamento diferente, cuja concentração do metal seguiu a ordem decrescente: ácido fúlvico > ácido húmico > humina. Destaca-se ainda, que no Espodossolo hidromórfico (P1) das amostras de ácido húmico foram observados valores de concentração de alumínio abaixo do limite de detecção do equipamento. Sugerindo que os altos valores do metal Aluminio obtido, nas amostras de solo inteiro (Tabela 5.I.7), possam estar associados à fração mais simples da matéria orgânica, com os ácidos fúlvicos, e também a fração mineral do solo. O metal Potássio não foi verificado nas amostras de ácido fúlvico e humina para os dois Espodossolos. 
Tabela 5.II.14: Concentrações dos metais Potássio (K), Ferro (Fe), Magnésio (Mg), Alumínio (Al) e Zinco (Zn) nas amostras das frações húmicas dos Espodossolos Amazônico.

\begin{tabular}{|c|c|c|c|c|c|c|}
\hline & \multirow{2}{*}{ AMOSTRA } & \multicolumn{5}{|c|}{ Concentração de metais em g/kg } \\
\hline & & Potássio & Ferro & Magnésio & Aluminio & Zinco \\
\hline \multirow{12}{*}{ 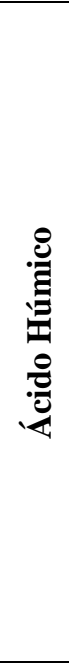 } & P1 A 0-15 & $1,2 \pm 0,3$ & $0,4 \pm 0,4$ & $0,9 \pm 0,3$ & $*$ & $0,05 \pm 0,01$ \\
\hline & P1 A-E 15-30 & $1,1 \pm 0,3$ & $0,3 \pm 0,3$ & $1,1 \pm 0,4$ & $*$ & $0,24 \pm 0,02$ \\
\hline & P1 Bh 40-50 & $1,2 \pm 0,4$ & $0,3 \pm 0,1$ & $0,8 \pm 0,1$ & $*$ & $0,10 \pm 0,01$ \\
\hline & P1 Bh-C 240 & $1,1 \pm 0,2$ & $0,6 \pm 0,7$ & $4,7 \pm 0,6$ & $*$ & $0,18 \pm 0,02$ \\
\hline & P1 C 350 & $1,0 \pm 0,1$ & $0,2 \pm 0,2$ & $1,7 \pm 0,1$ & $*$ & $0,23 \pm 0,01$ \\
\hline & P4 A 0-20 & $1,2 \pm 0,1$ & $1,8 \pm 0,5$ & $0,8 \pm 0,6$ & $6,4 \pm 0,3$ & $*$ \\
\hline & P4 A 20-30 & $1,4 \pm 0,1$ & $1,9 \pm 0,4$ & $1,5 \pm 0,3$ & $*$ & $0,10 \pm 0,02$ \\
\hline & P4 A 30-40 & $2,6 \pm 0,1$ & $2,3 \pm 0,3$ & $0,6 \pm 0,3$ & $*$ & $*$ \\
\hline & P4 A Bh 110-120 & $2,1 \pm 0,1$ & $1,1 \pm 0,2$ & $0,9 \pm 0,1$ & $*$ & $0,09 \pm 0,02$ \\
\hline & P4 Bh 170-180 & $1,0 \pm 0,1$ & $1,4 \pm 0,2$ & $1,2 \pm 0,2$ & $*$ & $0,14 \pm 0,03$ \\
\hline & P4 Bh 370-380 & $1,1 \pm 0,1$ & $1,2 \pm 0,6$ & $1,3 \pm 0,5$ & $*$ & $0,16 \pm 0,03$ \\
\hline & P4 Bh 380-390 & $1,1 \pm 0,1$ & $1,3 \pm 0,2$ & $1,9 \pm 0,7$ & $*$ & $0,19 \pm 0,01$ \\
\hline \multirow{12}{*}{$\frac{8}{\frac{8}{2}}$} & P1 A 0-15 & $*$ & $0,1 \pm 0,4$ & $*$ & $16,8 \pm 0,2$ & $*$ \\
\hline & P1 A-E 15-30 & $*$ & $*$ & $*$ & $13,8 \pm 0,5$ & $0,04 \pm 0,02$ \\
\hline & P1 Bh 40-50 & $*$ & $0,1 \pm 0,7$ & $0,2 \pm 0,4$ & $8,8 \pm 0,3$ & $0,07 \pm 0,02$ \\
\hline & P1 Bh-C 240 & $*$ & $*$ & $0,1 \pm 0,1$ & $*$ & $*$ \\
\hline & P1 C 350 & $*$ & $0,1 \pm 0,1$ & $*$ & $20,0 \pm 0,1$ & $*$ \\
\hline & P4 A 0-20 & $*$ & $0,2 \pm 0,1$ & $*$ & $9,5 \pm 0,1$ & $*$ \\
\hline & P4 A 20-30 & $*$ & $*$ & $*$ & $27,2 \pm 0,2$ & $*$ \\
\hline & P4 A 30-40 & $*$ & $*$ & $*$ & $17,5 \pm 0,1$ & $*$ \\
\hline & P4 A Bh 110-120 & $*$ & $*$ & $*$ & $13,7 \pm 0,4$ & $*$ \\
\hline & P4 Bh 170-180 & $*$ & $*$ & $*$ & $16,5 \pm 0,3$ & $*$ \\
\hline & P4 Bh 370-380 & $*$ & $*$ & $*$ & $20,5 \pm 0,2$ & $*$ \\
\hline & P4 Bh 380-390 & $*$ & $*$ & $*$ & $20,7 \pm 0,5$ & $*$ \\
\hline \multirow{12}{*}{ 䄈 } & P1 A 0-15 & $*$ & $0,3 \pm 0,1$ & $0,5 \pm 0,2$ & $*$ & $*$ \\
\hline & P1 A-E 15-30 & $*$ & $0,2 \pm 0,4$ & $0,3 \pm 0,3$ & $*$ & $*$ \\
\hline & P1 Bh 40-50 & $*$ & $0,2 \pm 0,2$ & $0,3 \pm 0,1$ & $*$ & $*$ \\
\hline & P1 Bh-C 240 & $*$ & $0,4 \pm 0,1$ & $0,3 \pm 0,2$ & $*$ & $*$ \\
\hline & P1 C 350 & $*$ & $1,0 \pm 0,2$ & $0,2 \pm 0,2$ & $5,0 \pm 0,1$ & $*$ \\
\hline & P4 A 0-20 & $*$ & $0,2 \pm 0,1$ & $0,2 \pm 0,1$ & $*$ & $*$ \\
\hline & P4 A 20-30 & $*$ & $0,2 \pm 0,1$ & $0,1 \pm 0,1$ & $*$ & $*$ \\
\hline & P4 A 30-40 & $*$ & $0,3 \pm 0,1$ & $0,2 \pm 0,3$ & $*$ & $*$ \\
\hline & P4 A Bh 110-120 & $*$ & $0,4 \pm 0,1$ & $0,2 \pm 0,3$ & $*$ & $*$ \\
\hline & P4 Bh 170-180 & $*$ & $0,3 \pm 0,1$ & $0,2 \pm 0,1$ & $*$ & $*$ \\
\hline & P4 Bh 370-380 & $*$ & $0,4 \pm 0,1$ & $0,3 \pm 0,3$ & $*$ & $*$ \\
\hline & P4 Bh 380-390 & $*$ & $0,3 \pm 0,1$ & $0,1 \pm 0,4$ & $*$ & $*$ \\
\hline
\end{tabular}

*Abaixo do limite de detecção da curva de calibração (K: 0,25 mg/kg; Fe: 0,10 mg/kg; $\mathrm{Mg}: 0,1 \mathrm{mg} / \mathrm{kg} ; \mathrm{Al:} 2,5$ $\mathrm{mg} / \mathrm{kg} ; \mathrm{Zn:} 0,05 \mathrm{mg} / \mathrm{kg}$ ).

Fonte: Autoria Própria. 
Na Tabela 5.II.14 pode-se observar que ao comparar as frações húmicas, a maior quantidade de metais que auxiliam na nutrição do solo, como Potássio, Ferro, Magnésio e Zinco estão presentes em maiores concentração na fração de ácido húmico. Os ácidos fúlvicos mostrou ter maior quantidade de $\mathrm{Al}$ em sua estrutura, permintindo inferir uma maior seletividade na interação com os metais, enquanto que o ácido húmico mostrou-se menos seletiva, pois possui em sua estrutura maiores quantidades de metais. Desta forma, o ácido húmico por ter essa maior afinidade pelos metais, deve ser o principal responsável pela fertilidade do solo. Por fim, a podzolização desses Espodossolos, mostra que as três frações húmicas estão envolvidas em seu processo de formação. O AF tem papel predominante no transporte de $\mathrm{Al}$ (8,8 a 27,2 g/kg), uma vez que essa fração apresentou maior quantidade desse metal em sua estrutura, enquanto que o $\mathrm{AH}$ é responsável pelo transporte do metal Fe, devido a sua grande quantidade que variaram de 0,2 a $2,3 \mathrm{~g} / \mathrm{kg}$.

\section{II.5. Espectroscopia de Emissão Óptica com Plasma Induzido por Laser}

A Figura 5.II.52 apresenta um espectro típico da Espectrometria de Emissão Ótica com Plasma Induzido por Laser, do acrônimo inglês LIBS, operando em regime de duplo pulso para amostras de solo inteiro e frações húmicas extraídos dos Espodossolos Amazônicos. 
Figura 5.II.52: Espectro típico obtido pelo LIBS com duplo pulso para amostra do Espodossolo hidromórfico (P1 A 0-15): (a) solo inteiro, (b) ácido húmico, (c) ácido fúlvico e (d) humina.
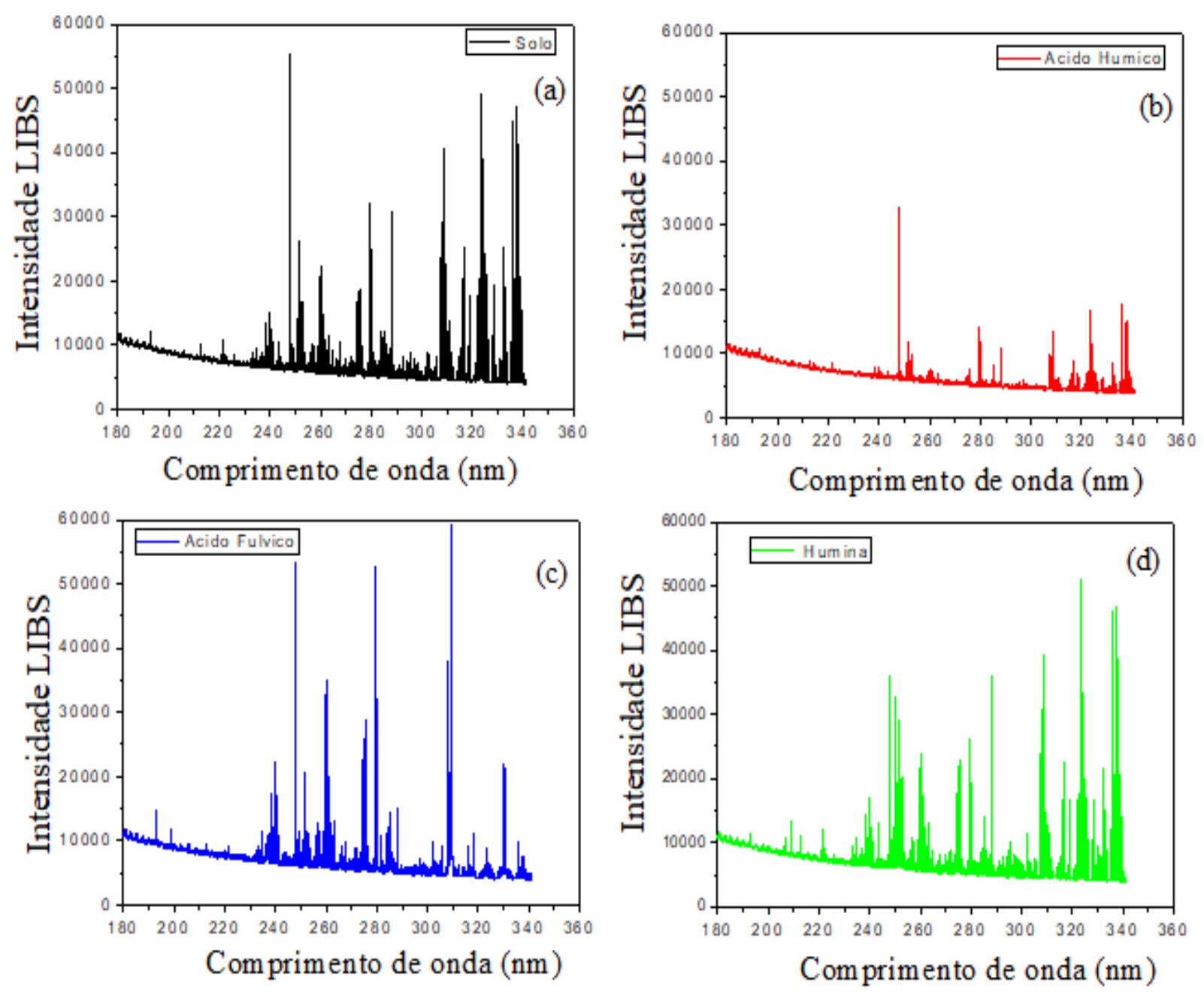

Fonte: Autoria Própria.

Após a obtenção dos espectros pelo LIBS, selecionaram-se algumas linhas para o tratamento dos dados, a fim de determinar a concentração de alguns elementos presentes na amostra. As linhas selecionadas nesse estudo foram 238, 279, 285 e $309 \mathrm{~nm}$ que correspondem aos macro e micronutrientes: Ferro, Magnésio, Manganês e Alumínio, conforme observado na Figura 5.II.53. 
Figura 5.II.53: Representação espectral do LIBS com duplo pulso para amostra do Espodossolo hidromórfico (P1 A 0-15) das linhas: (a) $238 \mathrm{~nm}$ (Ferro), (b) $279 \mathrm{~nm}$ (Magnésio), (c) $285 \mathrm{~nm}$ (Manganês) e (d) $309 \mathrm{~nm}$ (Alumínio).

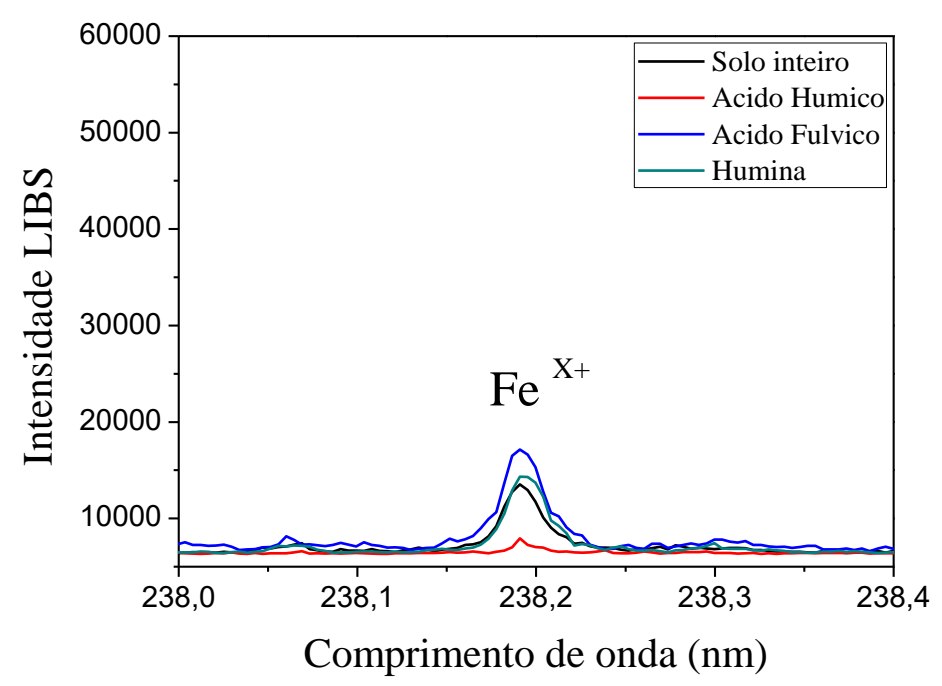

(a)

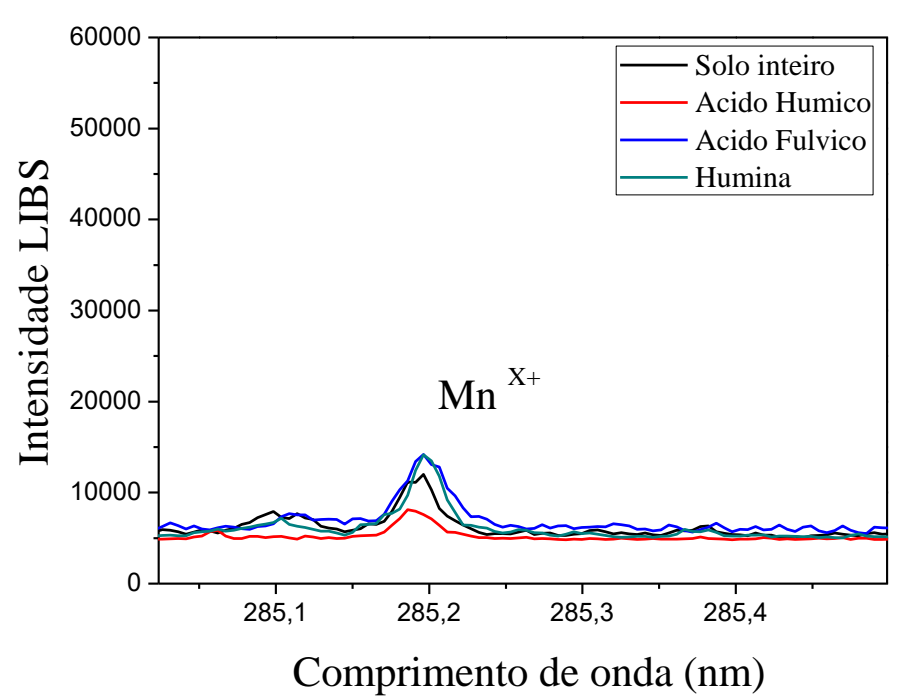

(c)

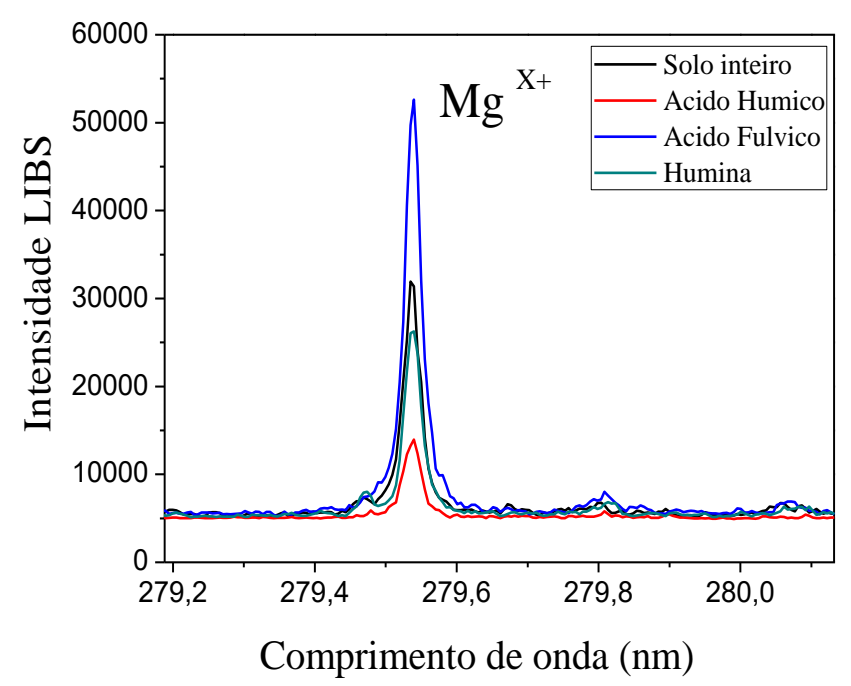

(b)

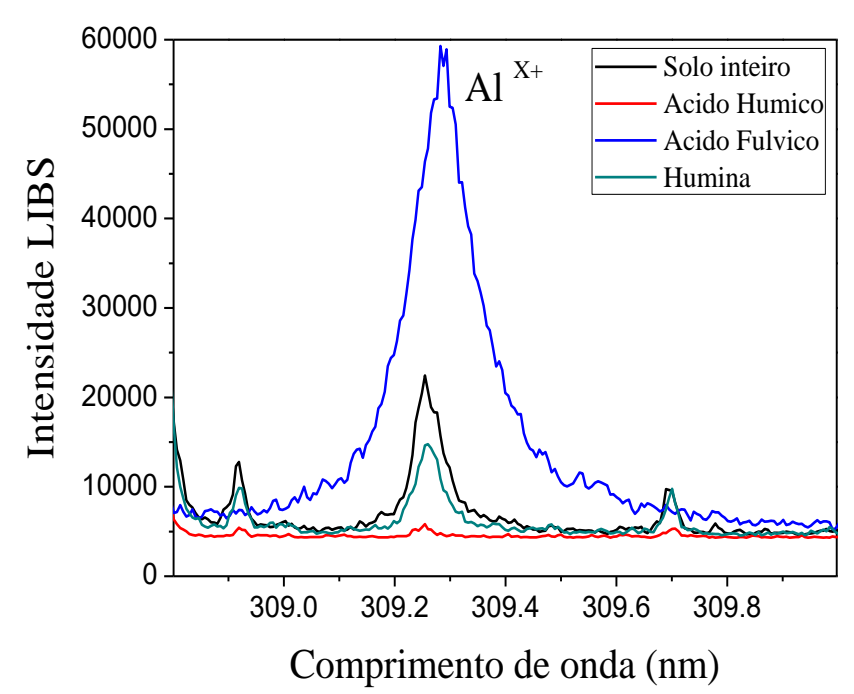

(d)

Fonte: Autoria própria.

Os espectros de emissão do LIBS oferece uma visão qualitativa da composição elementar da amostra. A análise quantitativa de um espectro LIBS, não é uma tarefa fácil, uma vez que cada linha de emissão representa um elemento químico, e essas linhas estão relacionadas com a complexidade da amosta, principalmente em solos, os quais não são homogêneos. Assim, os efeitos de matriz dos espectros LIBS podem ocorrer, dentre os quais: o plasma pode não ionizar igualmente todos os elementos presente na amostra, podendo criar variações no equilíbrio entre os átomos neutros e ionizados (Ferreira et al. 2011). 
Assim, os espectros LIBS foram utilizados a fim de permitir uma classificação mineralógica para esses solos em função de algumas linhas espectrais descritas na Figura 5.II.53, e posteriomente realizado um tratamento estatístico Análise de Componente Principal (ACP) utilizando o programa Matlab R2013a, cujo resultado está apresentado na Figura 5.II.54.

Figura 5.II.54: Análise de Componente Principal para as amostras de Ácido Húmico, Ácido Fúlvico e Humina extraídos dos Espodossolo hidromórfico (P1) e Espodossolo bem drenado (P4) em relação aos metais: (a) Ferro (linha 238 nm); (b) Magnésio (linha 279 nm); (c) Manganês (linha 285 nm) e (d) Alumínio (linha 309 nm).

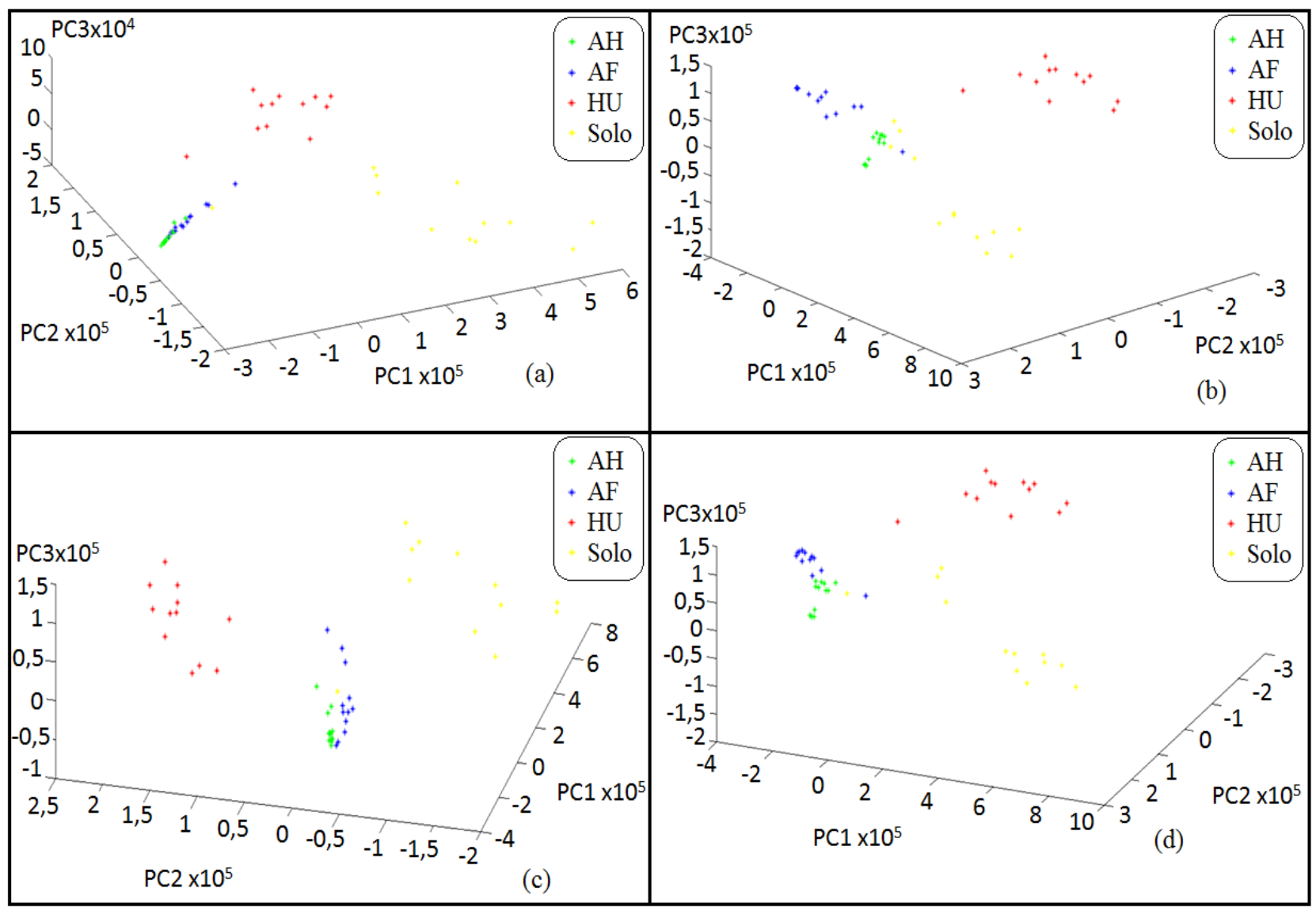

Fonte: Autoria própria.

Na Figura 5.II.54 observaram-se três grupamentos, sendo um formado pelo solo inteiro, o segundo pela fração humina e o terceiro pela mistura das amostras de ácido húmico e fúlvico que se aglomeram em um grupo único para os quatros linhas de metais estudadas. No entanto, ao observar atentamente os resultados, a maior separação dos grupos ocorreu nas linhas de Ferro em 238 nm (Figura 5.II.54(a)) e Manganês em 285 nm (Figura 5.II.54(b)). Enquanto que para as linhas de Magnésio em 279 nm (Figura 5.II.54(b)) e Alumínio em 309 
nm (Figura 5.II.54(d)) há uma parcela da fração humina e solo inteiro que mistura ao grupo pertencente às frações ácido húmico e fúlvico.

Assim, os resultados permitiram inferir que os ácidos húmicos e fúlvicos presentes nos Espodossolo hidromórfico (P1) e bem drenado (P4) apresentaram características semelhantes para as quatro linhas de elementares de Ferro, Magnésio, Manganês e Alumínio. Entretanto, as amostras da fração humina e do solo inteiro verificaram uma variação significativa para esta linha nesses solos. Além disso, a técnica de LIBS apresentou ser uma análise descritiva simples e rápida, capaz de auxiliar na determinação da composição elementar desse tipo de solo seguindo os princípios da química verde.

\section{II.6. Espectroscopia de Fluorescência Resolvida no Tempo}

A análise de Espectroscopia de Fluorescência Resolvida no Tempo (FRT) foi realizada durante o Doutorado em Cotutela na Université de Toulon - França no laboratório PROTEE sob a supervisão do Professor Dr. Stéphane Mounier.

A FRT tem sido empregada na determinação da constante de estabilidade de complexos metálicos, além de auxiliar na investigação da natureza do complexo, especialmente complexos ternários envolvendo mais de um ligante, como misturas de complexos hidroxi carbonatos e compostos orgânicos (Jain et al. 2008). Porém há poucos estudos que abordam como material de estudo a matéria orgânica e suas frações na análise de FRT. Assim, os dados apresentados nesse item foram os resultados inéditos para esse tipo de solos, os quais foram obtidos empregando um espectrômetro portátil da Quantaurus - Tau J da Hamatsu modelo C11367. Os resultados foram tratados empregando o software desenvolvido pelo fabricante do equipamento, e a curva típica obtida está representado na Figura 5.II.55. 
Figura 5.II.55: Curva típica obtida no tratamento do espectro de fluorescência resolvida no tempo do equipamento Quantaurus - Tau J para amostras dos ácidos húmicos do Espodossolos hidromórfico P1.
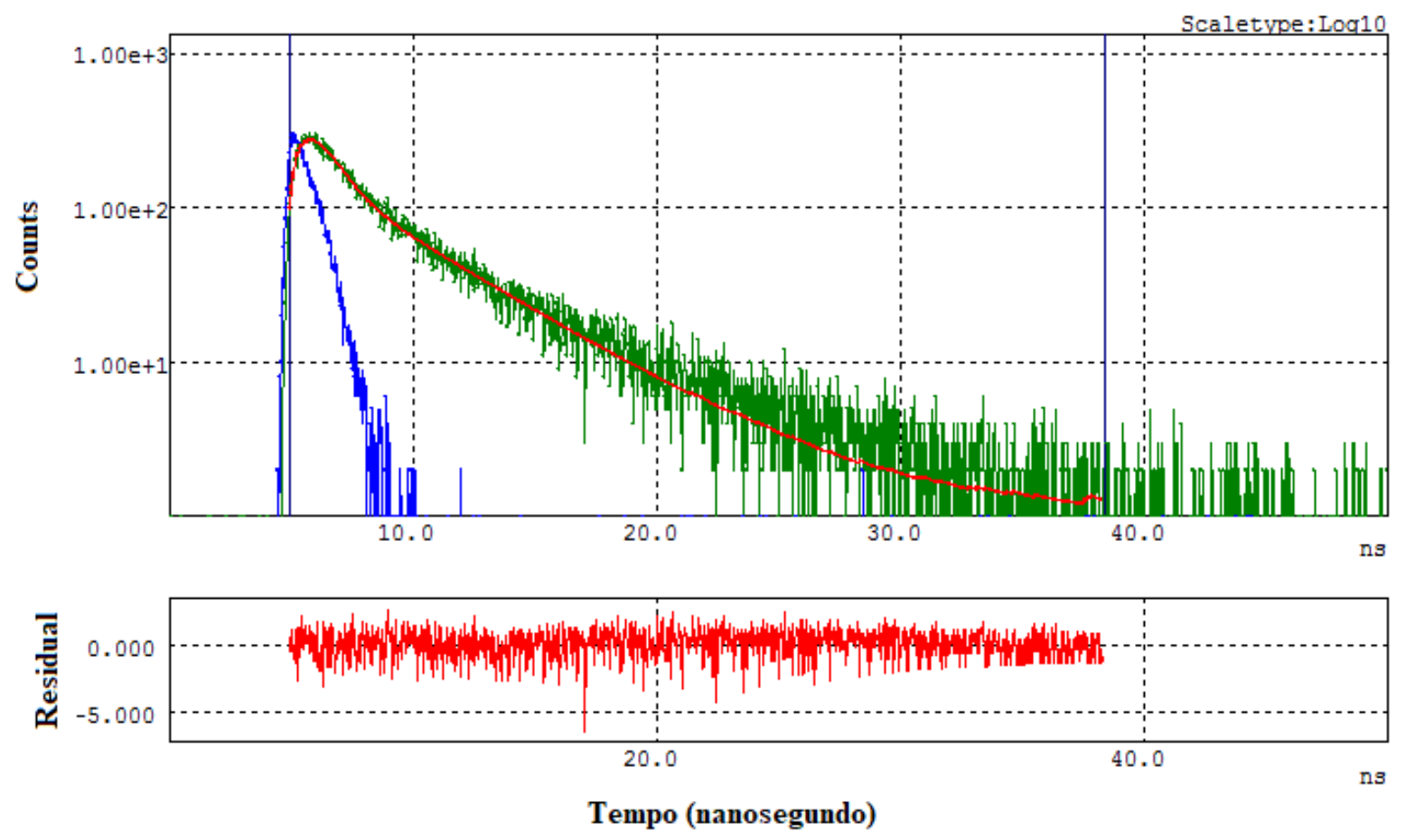

Fonte: Autoria Própria.

A Figura 5.II.56, apresenta os valores obtidos dos tempos de vida (T) 1 e 2, ou seja tempos de vida dos fluoróforos presente nas amostras de ácido húmico e ácido fúlvico dos Espodossolos Amazônico, empregando um Espectrômetro Portátil de Fluorescência Resolvida no Tempo. A curva de decaimento de fluorescência foi determinada por uma função bi-exponencial (Nicolodelli et al. 2017), conforme (equação 2):

$$
F(t)=a_{1} e^{\frac{t}{\tau_{1}}}+a_{2} e^{\frac{t}{\tau_{2}}}
$$

onde o T1 e T2 são valores dos tempos de vida de fluorescência curto e longo, respectivemante, e a1 e a2 são os coeficientes relacionados a cada componente.

Na Figura 5.II.56(a) destacam-se os horizontes P1 A 0-15 e P2 A 0-15 que obtiveram maiores valores de T1 na fração fúlvica quando comparado ao ácido húmico, comportamento contrário foi observado nos horizontes P3 Bh 180-183 e P4 Bh 170-180 em que os maiores valores de $\mathrm{T} 1$ foram na fração húmica. Os demais horizontes apresentaram valores intermediários de tempos de vidas para ambas as frações. Além disso, destacam-se os horizontes subsuperficiais e superficial (P1 A-E 15-30; P2 A-E 15-30 e P4 A 0-20, respectivamente) foram os que obtiveram os menores valores $\mathrm{T} 1$. 
Figura 5.II.56: Gráfico Tempo de vida (T1 e T2) para os (a) ácidos húmico e (b) ácidos fúlvicos extraídos dos Espodossolos Amazônico.
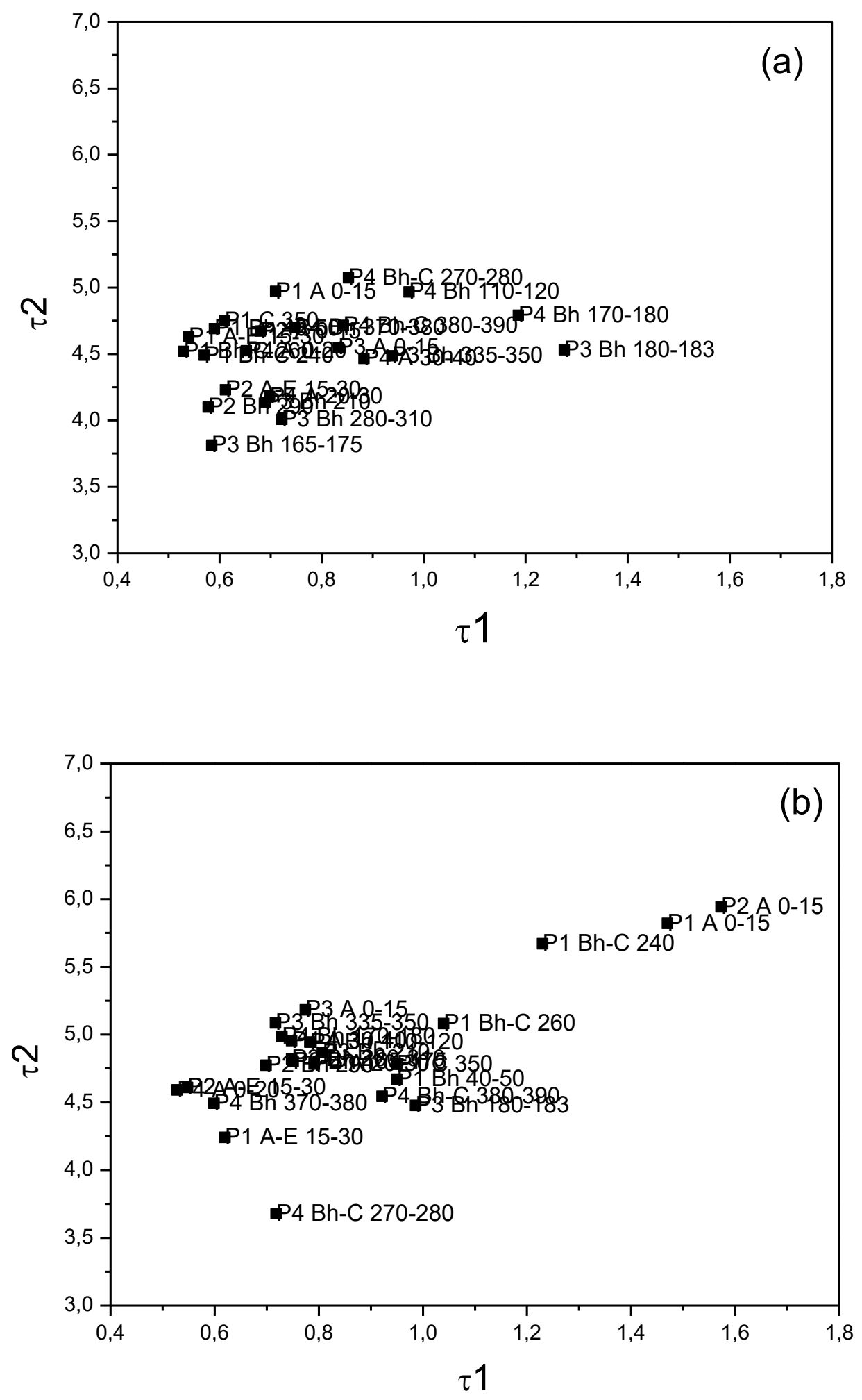

Fonte: Autoria própria. 
O T2 (Figura 5.II.56(b)) verificou-se maiores valores para ambas as frações nos horizontes P1 A 0-15, P1 Bh-C 240 e P2 A 0-15, e um maior grupamentos de horizontes com valores intermediários de tempo de vida foram observados para ambas as frações. O horizonte P4 Bh-C 270-280, destacou-se por apresentar o maior T2 para a fração húmica. Ademais, observa-se que o T1 há uma maior variação nos valores obtidos quando comparados ao T2 para as frações de ácido húmico e fúlvico, permintindo sugerir que T2 para ambas as frações, podem estar relacionadas a uma mesma origem de grupos de moléculas que foram excitadas.

Um fator interessante exibido nas Figuras 5.II.56(b), é que o T1 decai mais rápido para amostras de ácido fúlvico do que para amostras de ácido húmico. No que diz respeito ao tempo de decaimento, pode-se ver que a variabilidade é menor para as amostras de AH do que para os AF. Isso significa que AF pode ser mais reativo que $\mathrm{AH}$, assim, o AF é mais fácil de ligar a metais do que AH, podendo causar uma variação no tempo de vida entre as frações.

Além disso, no tempo de vida (T1, Figura 5.II.56(a)) dos ácidos fúlvicos observa-se uma diferenciação principalmente para os perfis P1 e P2, os quais são Espodossolos sob condição de hidromórfia, que está associado a estruturas mais simples e com emissão para comprimentos de onda menores na região do azul, favorecendo assim a complexação por metais dessa fração fúlvica.

Como existe uma variação maior entre os T1 e T2 para os ácidos fúlvicos, pode-se considerar que, mesmo se a decomposição CP/PARAFAC dá dois componentes, há mais fontes fluorescentes na fração de ácido fúlvico extraída desses solos Amazônicos. Esta dinâmica química no pool de ácido fúlvico é mais complexa do que no pool de ácido húmico. Ao comparar os dados obtidos pelo CP/PARAFAC na sessão 5.II.3.2 (páginas 99 e 104) as componentes CI e CII dos ácidos húmicos e fúlvicos respectivamente, apresentaram picos semelhantes, permitindo sugerir estar relacionados à mesma origem de moléculas nesses horizontes, especialmente para o tempo de vida T2 (Figura 5.II.56(b)), em que não há variação significativa entre as frações húmicas (Tadini et al. 2017, Anexo F, página 167).

\section{II.7. Espectroscopia de Ressonânica Magnética Nuclear}

A Figura 5.II.57, apresenta um espectro típico de Ressonância Magnética Nuclear (RMN) dos ácidos húmico e fúlvico extraídos do Espodossolo Hidromorfico P1. 
Figura 5.II.57: Espectro obtido pelo RMN das amostras de Ácido Húmico extraídos do Espodossolo Hidromórfico P1 (P1 A 0-15). Sendo que os deslocamentos químicos referem-se a: R1 (0-45 ppm) - carbonos alifáticos saturados (alcanos); R2 (45-90 ppm) - carbonos alifáticos ligados a O ou N (polissacarídeos); R3 (90-110 ppm) - carbonos anoméricos ligados a dois O (polissacarídeos); R4 (110-160 ppm) - carbonos aromáticos; R5 (160-190 ppm) - carbonos carbonílicos de ácidos carboxílicos, éster e amida (lipídeos e proteínas) e R6 (190-220 ppm) - carbonos carbonílicos de aldeídos e cetonas (Dignac et al. 2002; Simpson e Simpson, 2009).

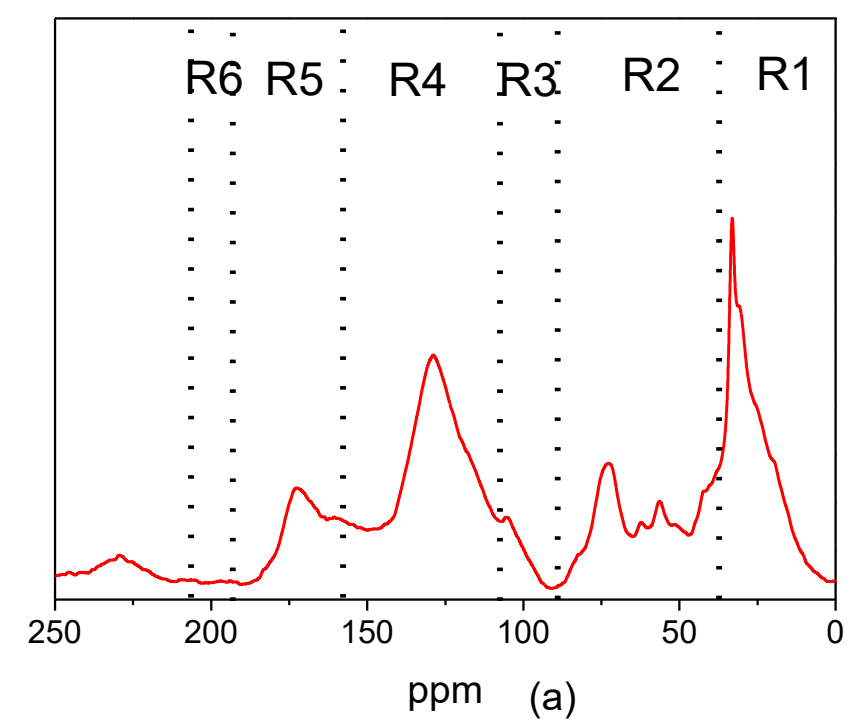

Fonte: Autoria Própria.

Na Figura 5.II.57, representando o espectro típico de RMN de uma amostra de ácido húmico num horizonte superficial (P1 A 0-15) e um horizonte mais profundo (P1 C 350). Pode-se observar picos na região de 30 a 34 ppm que pode ser atribuída ao carbono alquil sem substituição que incluem cadeias lineares de carbono metilenos; um pico em 56 ppm pode ser atribuído a grupos metóxila presente na lignina que aparecerá novamente em torno de 150 ppm com um ou dois picos, mais também essa região pode ser atribuída ao carbono alquil com N-substituído em proteínas e peptídeos; picos na região 65 a 95 ppm referente a presença de carbono ligado a substituintes de oxigênio e/ou carbonos ligados a grupos de éteres; picos na região de 110 a 160 ppm atribuído a presença de carbono ligados a grupos aromáticos e fenólicos, bem com um pico na região próximo a 175 ppm que pode se referir a presença de carbonos ligados a grupos carboxílicos, amidas e ésteres (Dignac et al. 2002; Simpson e Simpson, 2009).

Além disso, nesses espectros foi observado que com o decorrer da profundidade há uma variação da intensidade da região pertencente aos grupos aromáticos conforme apresentado na Figura 5.II.57(a), comportamento semelhante foram observados para os 
Espodossolos hidromórficos P2 e P3, e o Espodossolo bem drenado P4. Destaca-se a região dos grupos de carbonos alifáticos (0-45 ppm e 45-60 ppm) que obteve maiores intensidade com o decorrer da profundidade especialmente nos Espodossolos hidromórficos P2 e P3. Destaca-se, que devido a grande quantidade de cinzas obtida na fração ácido fúlvico, essa amostra não foi analisado o espectro de Ressonância Magnética Nuclear.

A Tabela 5.II.15 apresenta os valores relativos de cada grupo estrutural do carbono nas amostras de ácido húmico, extraídos dos Espodossolos Amazônico, após a integração da área para faixa espectral. As amostras de ácido húmico apresentaram uma mistura de área relativa dos grupamentos alifáticos e aromáticos, destacando-se o Espodossolo bem drenado P4. Há um aumento da área relativa do carbono aromático com o decorrer da profundidade, enquanto que nos outros Espodossolos P1, P2 e P3 não verificou variação significativa entre as áreas relativas $(22,8$ a $33,3 \%)$.

Tabela 5.II.15: Valor relativo (\% da área total) dos grupos espectrais do ${ }^{13} \mathrm{C}$ RMN das amostras de ácido húmico dos Espodossolos Amazônico.

\begin{tabular}{c|cccc}
\hline \multirow{2}{*}{ Horizontes } & \multicolumn{4}{|c}{ Deslocamento químico (ppm) } \\
& Alquil & Metóxilas & Aromáticos & Carboxílas e Carbonilas \\
& $\mathbf{0 - 4 5}$ & $\mathbf{4 5 - 1 1 0}$ & $\mathbf{1 1 0 - 1 6 0}$ & $\mathbf{1 6 0 - 2 3 0}$ \\
\cline { 2 - 5 } & \multicolumn{4}{|c}{ Ácido Húmico } \\
\hline P1 A 0-15 & 29,9 & 21,7 & 33,3 & 15,1 \\
P1 A 15-30 & 38,6 & 22,0 & 27,8 & 11,6 \\
P1 Bh-C 260 & 34,4 & 23,0 & 26,3 & 16,3 \\
P1 Bh-C 350 & 36,4 & 25,8 & 27,9 & 10,0 \\
\hline P2 A 0-15 & 36,3 & 25,7 & 27,9 & 10,1 \\
P2 A-E 15-30 & 27,5 & 39,8 & 23,6 & 9,1 \\
P2 Bh 290 & 30,9 & 27,4 & 28,8 & 13,0 \\
\hline P3 A 0-15 & 26,5 & 40,9 & 22,8 & 9,8 \\
P3 Bh 165-175 & 32,0 & 26,2 & 28,3 & 13,5 \\
P3 Bh 210 & 32,5 & 23,1 & 30,0 & 14,4 \\
P3 Bh 280-310 & 25,5 & 20,3 & 37,2 & 17,0 \\
\hline P4 A 0-20 & 29,7 & 42,6 & 19,6 & 8,2 \\
P4 Bh 110-120 & 30,8 & 15,8 & 38,5 & 14,8 \\
P4 Bh-C 270-280 & 33,6 & 14,7 & 35,9 & 15,7 \\
P4 Bh 380-390 & 5,2 & 16,7 & 53,2 & 24,9 \\
\hline
\end{tabular}

Fonte: Autoria Própria.

Os espectros de ${ }^{13} \mathrm{C}$ RMN dos ácidos húmicos de maneira geral apresentaram detritos de plantas frescas como celulose (picos em 73 e 103 ppm, O-alquil e di-O-alquil respectivamente) e grupos de carbono alquil (picos 0-40 ppm) e compostos vegetais como 
cutina, suberina e ceras, além de sinais da presença de lignina (145-162 ppm de grupos O-aril e 56 ppm de grupos O-aril e N-alquil) (Kögel-Knabner, 1997; Song et al., 2008; Segnini et al. 2012). O sinal de intensidade elevado na região de 130 ppm para carbono aromático substituído nas frações húmicas mostra que a estrutura de lignina presente nesse material está altamente alterada e/ou materiais com estrutura derivadas de fontes como carvão vegetal está presente no solo (Kögel-Knabner, 1997).

Nas amostras de ácidos húmicos ficou evidente um aumento significativo na área relativa a grupos de carbono carboxílicos, principalmente nos Espodossolos hidromórficos e bem drenados, P3 e P4, respectivamente. Assim, podendo associar a uma oxidação parcial desse material, levando a um processo de humificação maior nos horizontes mais profundos, no entanto ácidos graxos como cutina, suberina e ceras, podem contribuir para o sinal de grupos carboxílicos (Song et al., 2008). Segnini et al. (2012) utilizando amostras de matéria orgânica de solos alagados (região de Huayllapata, Puno, Peru) observaram que nos espectros de ${ }^{13} \mathrm{C}$ RMN o sinal de carbono carboxílicos próximo a 169 ppm foram nos horizontes mais profundos nesses solos alagados. Segundo esses autores, este sinal pode ser atribuído a carbono carboxílico de anéis aromáticos provenientes de resíduos de proteínas. Além disso, esses autores observaram a entrada de lignina e seus derivados com o aparecimento de picos na região de 150-160 ppm, porém sendo confirmado com o aparecimento também do pico em $56 \mathrm{ppm}$. Comportamento semelhante foi observado nas frações húmicas estudadas nesse trabalho, principalmente na fração de ácido húmico para os Espodossolos Amazônico.

$\mathrm{Na}$ Tabela 5.II.16 são exibidas as porcentagens de alifaticidade e aromaticidade calculada a partir dos espectros obtidos pelo RMN, seguindo as equações descritas no item 4.3.9 (página 59).

Observou que a aromaticidade das frações de ácido húmico aumentou com o decorrer da profundidade o que pode ser explicado pelo processo de humificação aumentando assim, a concentração de estruturas mais aromáticas nesses horizontes. González-Pérez et al. (2008) analisando amostras de ácido húmico de Espodossolo da Ilha de Cardoso em SP, observou-se que a contribuição dos grupos alifáticos nessas amostras foram maiores que do grupos aromáticos, obtendo valores de 75 a $24 \%$ de porcentagem relativa. Os resultados obtidos nesse trabalho corroboram com outros estudos descritos na literatura em relação aos valores de alifaticidade e aromaticidade (Chen et al. 2002; González-Pérez et al. 2004; GonzálezPérez et al. 2008; Song et al. 2008; Tadini et al. 2015). Os ácidos húmicos apresentaram maiores valores de alifaticidade quando comparados à aromaticidade, com exceção dos horizontes: P3 Bh 280-310 que apresentaram maiores valores de aromaticidade. 
Tabela 5.II.16: Porcentagem de alifaticidade e aromaticidade das amostras de ácido húmico dos Espodossolos Amazônico.

Fonte: Autoria Própria.

\begin{tabular}{|c|c|cc}
\hline & Amostras / Horizontes & Alifaticidade (\%) & Aromaticidade (\%) \\
\cline { 2 - 4 } & P1 A 0-15 & 54,41 & 45,65 \\
P1 A 15-30 & 60,89 & 39,11 \\
P1 Bh-C 260 & 60,91 & 39,09 \\
P1 Bh-C 350 & 60,66 & 39,34 \\
\hline P2 A 0-15 & 60,54 & 39,46 \\
P2 A-E 15-30 & 66,09 & 33,91 \\
P2 Bh 290 & 57,57 & 42,43 \\
\hline P3 A 0-15 & 58,88 & 41,12 \\
P3 Bh 165-175 & 52,79 & 47,21 \\
P3 Bh 210 & 53,74 & 46,26 \\
P3 Bh 280-310 & 38,8 & 61,2 \\
\hline P4 A 0-20 & 69,79 & 30,21 \\
P4 Bh 110-120 & 50,44 & 49,53 \\
P4 Bh-C 270-280 & 53,76 & 46,24 \\
P4 Bh 380-390 & 52,39 & 47,61 \\
\hline
\end{tabular}

\section{II.8. Análise de Componentes Principais}

Para uma melhor compreensão e correlação dos resultados foi aplicada uma Analise de Componentes Principais (ACP), nos resultados obtidos cada fração húmica pelas técnicas: de análise elementar, Ultravioleta Vísivel, Espectroscopia de Fluorescência e Espectroscopia de Infravermelho com Transformada de Fourier das amostras de ácido húmico e fúlvico extraídos dos Espodossolos Amazônico, conforme a Figura 5.II.58.

A Figura 5.II.58 observou-se uma boa separação entre os horizontes das amostras de ácidos húmico destacados nos tons de verde, em que se verificaram agrupamentos entre os horizontes A e A-E, e principalmente entre os horizontes Bh e Bh-C. Enquanto que para as amostras de ácidos fúlvicos essa separação entre os horizontes não foi nítido. Assim, esse resultado mostrou uma boa separação entre as frações húmicas, cujo parâmetro que responsável por essa separação foi à banda C-O do FTIR, demonstrando assim, que a fração húmica apresenta maiores características aromáticas que os ácidos fúlvicos. Ademais, foi verificado se houve separação entres os perfis estudados pela ACP, o resultado está apresentado na Figura 5.II.59. 
Figura 5.II.58: Análise de Componentes Principais (ACP) dos ácidos húmicos e fúlvicos pelos horizontes estudados.

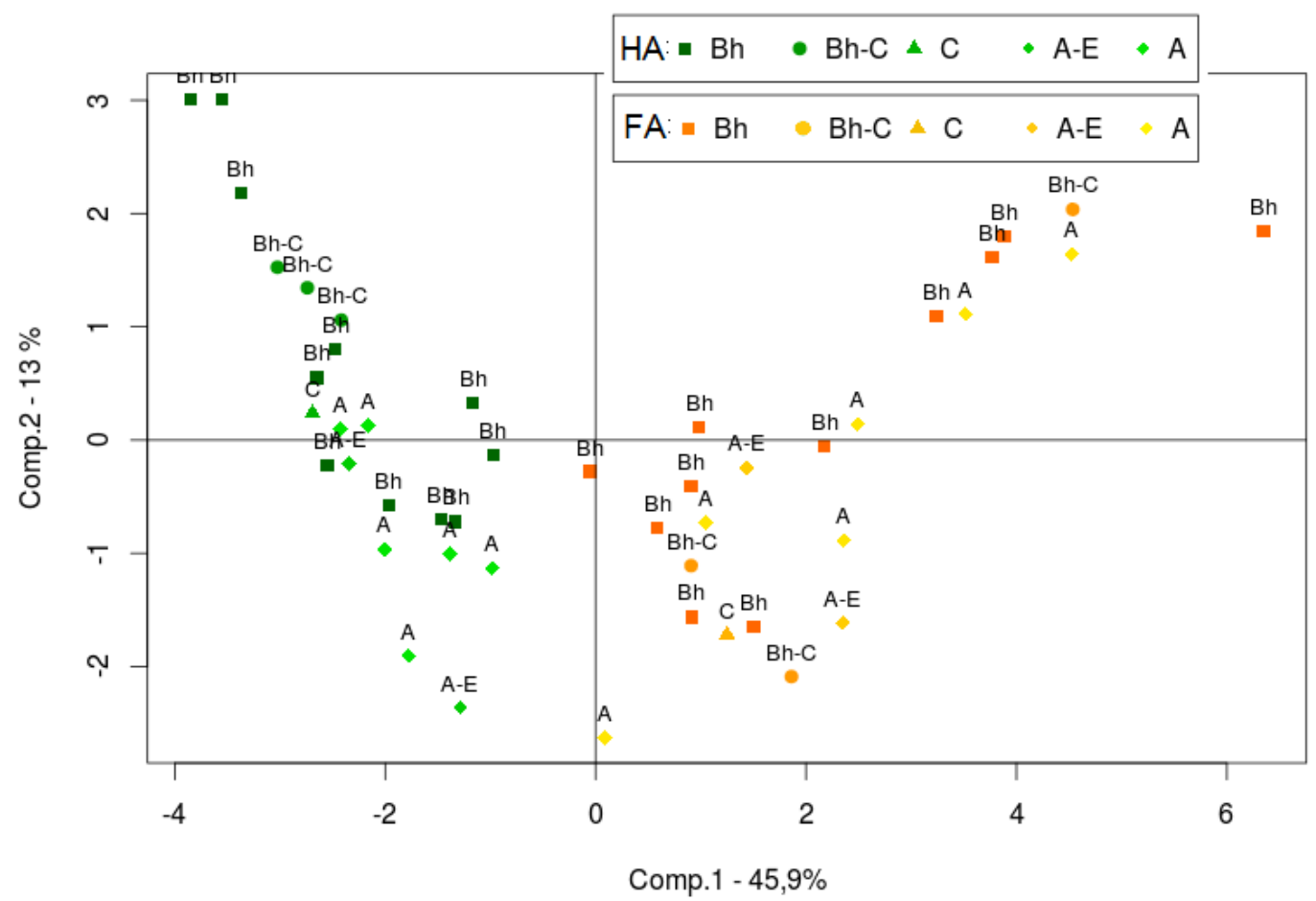

Fonte: Autoria Própria.

Figura 5.II.59: Análise de Componentes Principais (ACP) dos ácidos húmicos e fúlvicos pelos Perfis estudados.

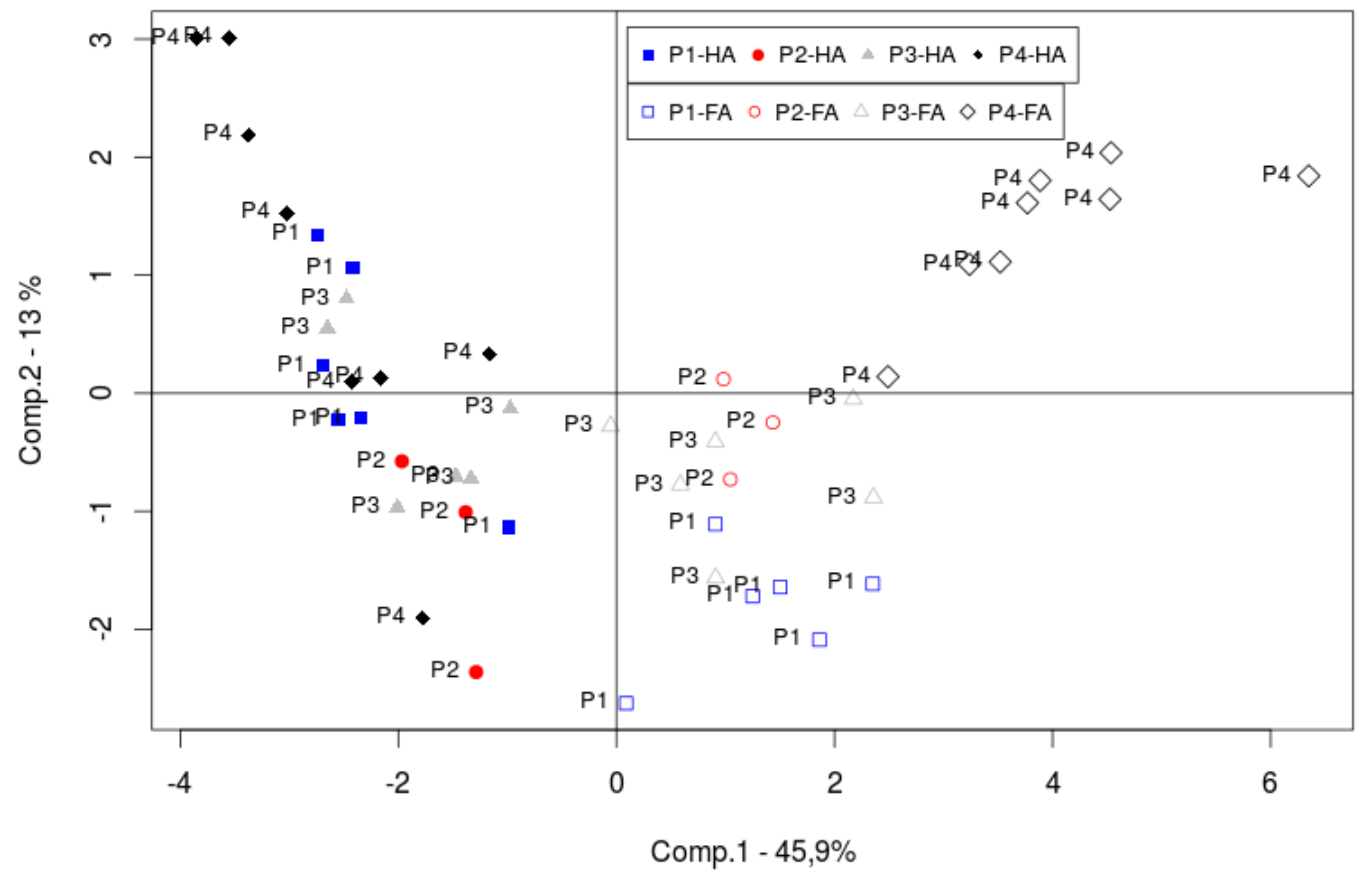

Fonte: Autoria Própria. 
Na Figura 5.II.59, verificou-se uma boa separação por Perfil estudado para as frações fúlvicas, destacando-se os Perfis P1, P2 e P3, que possuem a influência do lençol freático em alguns horizontes, permitindo associar que os ácidos fúlvicos com características mais alifáticas possuem uma maior mobilidade e interação com a água. Enquanto que para as frações de ácidos húmicos não foi possível verificar essa separação por Perfil, mas sim por horizonte, demonstrando assim, que essa fração está associada a uma maior interação com os constituintes do solo.

\section{II.9. Considerações parciais}

Os ácidos húmicos do Espodossolos Amazônicos apresentaram características estruturais dependendo do processo pedológico, conforme observado pelos $\mathrm{H}_{\text {LIFS-M }}$ do solo e $\mathrm{A}_{465 \mathrm{~nm}}$ do ácido húmico. Além disso, essa fração apresentou maior variabilidade com o decorrer do horizonte. Desta forma, os valores dos índices de humificação sugerem que nos horizontes superficiais inclui compostos simples, lábeis e um ácido húmico menos humificado, enquanto que os compostos humificados mais complexos são lixiviados e acumulados em horizontes mais profundos. Os resultados sugerem que a lignina possui características semelhantes às dos ácidos húmicos presentes nos horizontes intermediários de humificação, como observado na Figura 5.I.12 e Figura 5.II.32. Portanto, uma hipótese, é que há dois processos de gêneses da MO nesses solos, uma de origem de derivado de ligninas modificadas e a outra da transformação (condensação) de polifenóis.

A quantificação de carbono nas frações húmicas mostrou a importância da Humina para o estudo da MO em diferentes horizontes no Espodossolos Amazônicos. As frações húmicas (AH, AF e HU) possuem em sua estrutura molecular dois Fluoróforos, sendo um Fluoróforo (CI) referente a grupos mais alifáticos e o Fluoróforo (CII) a grupos mais aromáticos.

Os espectros de ${ }^{13} \mathrm{C}$ RMN dos ácidos húmicos apresentaram detritos de plantas frescas como celulose, grupos de carbono alquil, compostos vegetais (cutina, suberina e ceras), além de sinais da presença de lignina. Nas amostras de ácidos fúlvicos apresentaram maiores quantidades de grupos oxigenados, tais como carboxílicos e cetônicos. A fração AF do solo parece ter uma contribuição oriunda de lençóis freáticos, sua estrutura química varia pouco no perfil e possui seletividade na interação com os metais presentes nesses solos.

Ao avaliar a quantidade de metais nas frações húmicas verificou-se que os ácidos fúlvicos têm alta afinidade de complexação com o $\mathrm{Al}$, enquanto que os ácidos húmicos 
mostrou-se menos seletiva, complexando-se com vários tipos de metais, como $\mathrm{K}, \mathrm{Fe}, \mathrm{Mg}, \mathrm{Zn}$ e Al; e sua estrutura química varia bastante no perfil do solo. Em função da diversidade de metais que o AH tem afinidade, ele deve ser o principal responsável pela fertilidade do solo. Desta forma, os resultados mostraram que as três frações húmicas estão envolvidas no processo de Podzolização, e que o AF tem papel predominante no transporte de $\mathrm{Al}$ e o AH é o protagonista no transporte do Fe.

No que diz respeito ao tempo de vida das frações húmicas, pode-se ver que a variabilidade é menor para as amostras de $\mathrm{AH}$ do que para os AF. Permitindo inferir que os AF podem ser mais reativos que $\mathrm{AH}$. Assim, o AF é mais fácil de ligar a metais do que $\mathrm{AH}$, e podendo causar uma variação no tempo vida entre as frações.

Análise de Componentes Principais (ACP) mostrou que a fração de AH apresenta maiores características aromáticas que os $\mathrm{AF}$, corroborando estudos descritos na literatura. Ademais, verificou-se uma boa separação por perfil estudado nos AF, destacando-se os perfis P1, P2 e P3, que possuem a influência do lençol freático em alguns horizontes. Demonstrando assim, que os AF com características mais alifáticas possuem uma maior mobilidade e interação com a água. Os AH não foram possíveis verificar essa separação por perfil, e sim por horizonte, permitindo inferir que essa fração está associada a uma maior interação com os constituintes do solo. 
Capítulo 5 - Resultados e Discussão 
Parte III - Estudo da interação dos Ácidos Húmicos e Ácidos Fúlvicos com os metais 


\section{III.1. Interações dos Ácidos Húmicos e Ácidos Fúlvicos com os metais Cobre (II) e Al (III)}

Para entender o processo da interação matéria orgânica-metal $\left(\mathrm{M}_{\mathrm{a}} \mathrm{L}_{\mathrm{b}}\right)$ é preciso levar em consideração o seguinte equilibrio reacional:

$$
{ }_{\mathrm{a}} \mathrm{M}+{ }_{\mathrm{b}} \mathrm{L} \leftrightarrow \mathrm{M}_{\mathrm{a}} \mathrm{L}_{\mathrm{b}}
$$

que é descrito pela constante de estabilidade $\mathrm{K}$, onde:

$$
\mathrm{K}=\left(\left[\mathrm{M}_{\mathrm{a}} \mathrm{L}_{\mathrm{b}}\right]\right) /\left([\mathrm{M}]^{\mathrm{a}} \mathrm{x}[\mathrm{L}]^{\mathrm{b}}\right)
$$

A complexidade analítica da constante de estabilidade condicional depende da natureza da ligação envolvida na reação, em que há três tipos de ligação: i) ligação simples $\mathrm{M}_{\mathrm{a}} \mathrm{L}_{\mathrm{b}}$ onde $\mathrm{a}=\mathrm{b}=1$; ii) complexos mononucleares com dois substratos maiores onde $\mathrm{a}$ molécula central do complexo é o ligante ou o metal $\mathrm{M}_{\mathrm{a}} \mathrm{L}_{\mathrm{b}}, \mathrm{a}=\mathrm{b} \geq 2$; iii) ligações polinucleares onde $M_{a} L_{b}, a>1$ e $b>1$, e pode envolver um ou mais metais na ligação (Wolf, 1994).

O rendimento quântico de fluorescência de uma molécula é reduzido na presença de uma molécula de quencheur, como oxigênio ou halogênios. Se o quenching depende linearmente da concentração do agente causador do quenching, então o quenching segue uma cinética química, seguindo a teoria proposta por Stern Volmer (Lum, 1978).

Vale destacar que os resultados dessa sessão foram dividos em duas partes relativas à Supressão de Fluorescência, sendo a primeira na modalidade bidimensional e a segunda na modalidade tridimensional, sendo que nesta última, os dados foram tratados, posteriormente com a ferramenta matemática de Análise de Fatores Paralelos (CP/PARAFAC).

Sabe-se que os ácidos húmicos e ácidos fúlvicos possuem forte interação com elementos (íons metálicos) do tipo actínidos divalentes e trivalentes, pois são capazes de formarem complexos quelatos pouco fluorescentes, sendo possível determinar a quantidade de sítios capazes de participar dessa interação, bem como a força dessa interação pela determinação da capacidade de complexação e constante de estabilidade, respectivamente (Fröhlich et al. 2014). Desta forma, foram escolhidos os íons Cu (II) e Al (III) para fornecer tais informações estruturais das frações húmicas extraídas dos Espodossolos Amazônico.

A Figura 5.III.60 exibe os espectros obtidos pela Espectroscopia de Fluorescência de Supressão, também denominado Análise de Quenching, para as amostras de ácido húmico do P1 A 0-15 com diferentes concentrações do metal $\mathrm{Cu}$ (II). Pode-se verificar uma diminuição da intensidade de fluorescência com o aumento da concentração do metal adicionado à amostra. O mesmo comportamento foi observado para as demais amostras dos Perfis P2, P3 e P4 das frações de ácidos húmicos e fúlvicos, bem com a interação do metal Alumínio (III). 
Figura 5.III.60: Espectro de fluorescência na modalidade matriz emissão-excitação (MEE) para a amostra de ácido húmico extraído do P1 A 0-15, em que: (a) ácido húmico sem adição de Cu (II); (b) ácido húmico com

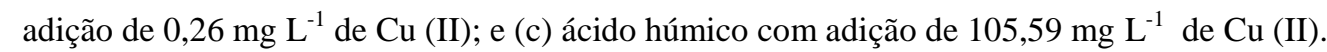

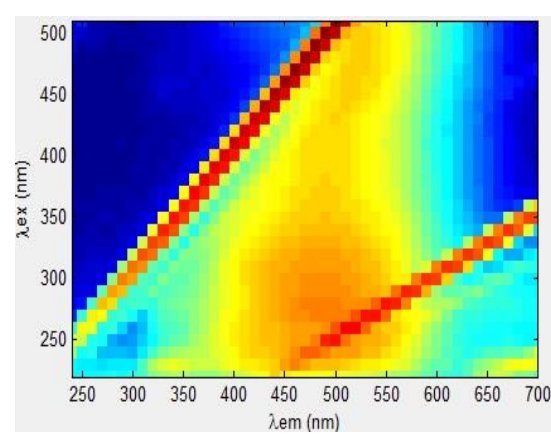

(a)

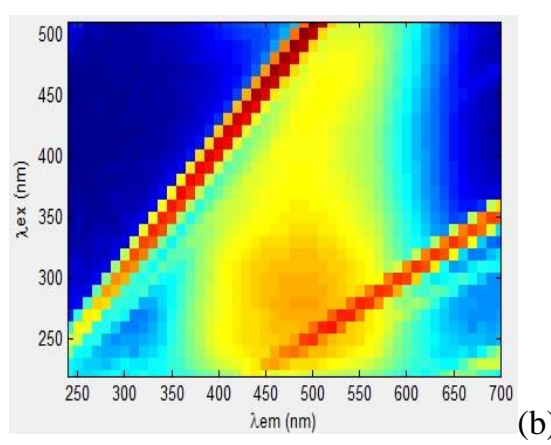

(b)

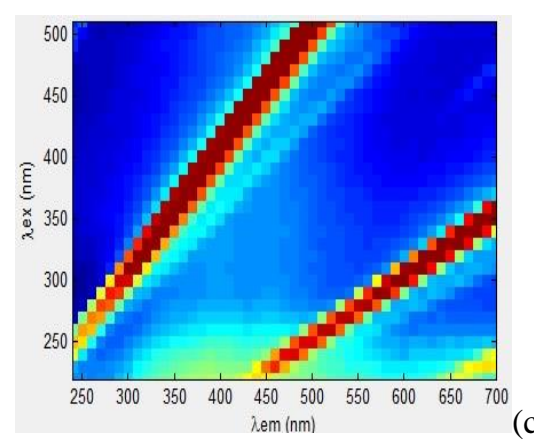

Fonte: Autoria Própria.

Os espectros foram tratados pelo CP/PARAFAC, e forneceu alguns Fluoróforos, denominados Componentes, que são responsáveis pela Fluorescência na amostra, as quais estão apresentadas na Tabela 5.III.17 para os Espodossolos Amazônico. O paramêtro utilizado para definir a probabilidade do Componente estar correto é denominado como diagnóstico de consistência de tensor (também conhecido como Concórdia). Os valores variaram de 95,30 a 98,96\% nos ácidos húmicos, de 93,93 a 99,88\% nos ácidos fúlvicos com a interação com os íons $\mathrm{Cu}$ (II), e de 97,19 a 99,57\% para os $\mathrm{AH}$ e de 95,60 a 99,65\% para os AF interagindo com os íons Al (III).

Tabela 5.III.17: Componentes obtidas pelo CP/PARAFAC para as amostras de Ácido Húmico (A e B) e Fúlvico (C, D, E e F) extraídos dos Espodossolos Amazônico com os íons Cu (II) e Al (III).

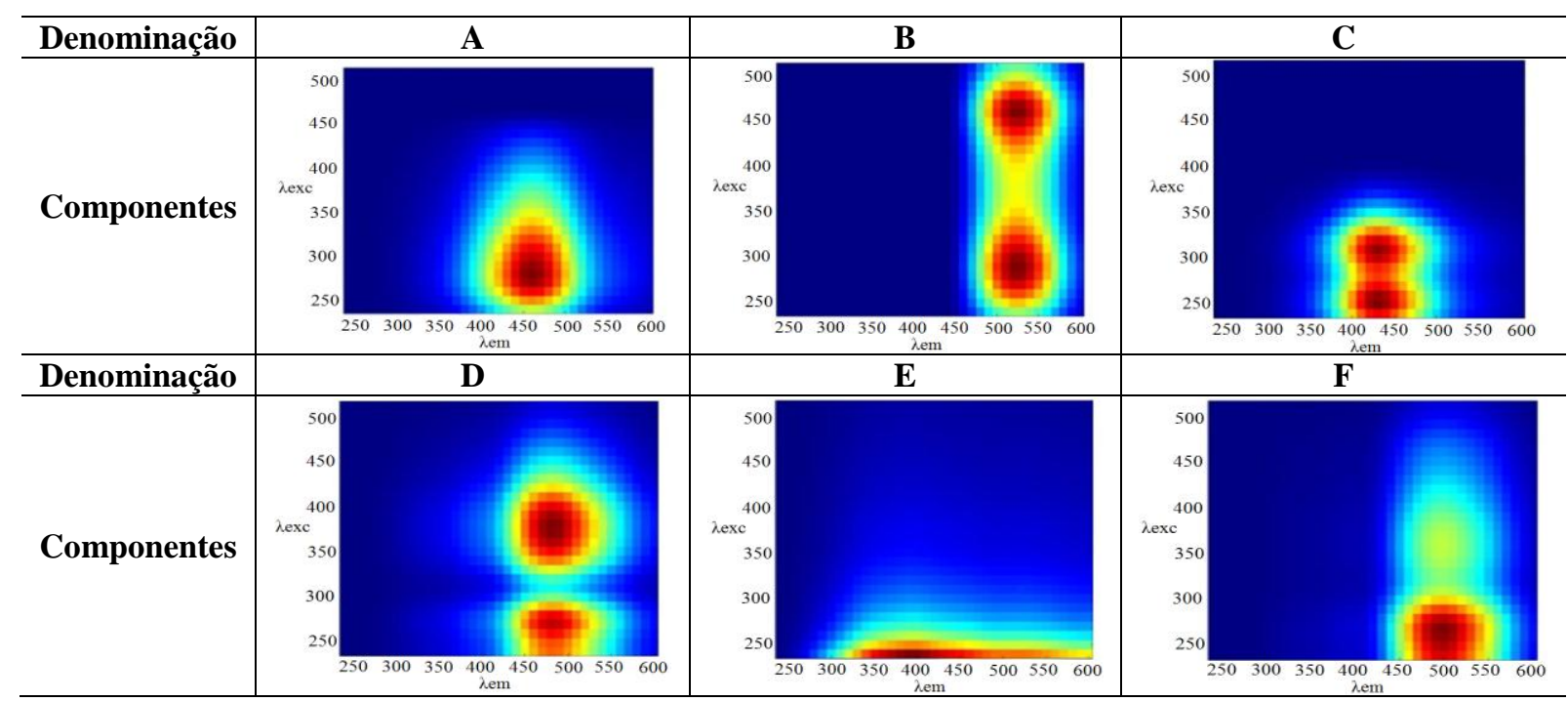

Fonte: Autoria própria.

A Tabela 5.III.17, apresenta as principais Componentes obtidas pelo CP/PARAFAC 
para as amostras de ácido húmico e fúlvico com os íons $\mathrm{Cu}$ (II) e $\mathrm{Al}$ (III) dos Espodossolos Amazônico. Se verificarmos as Componentes do CP/PARAFAC obtidas sem interação dos metais no item 5.II.3.2. (páginas 99 a 106), as CI e CII dos ácidos húmicos referem-se às letras A e B respectivamente, e as CI e CII dos ácidos fúlvicos referem-se as letras C e F respectivamente. Desta maneira, a interação com os íons metálicos, apresentou novos grupos fluorescentes apenas para amostras de ácidos fúlvicos, ou seja, os grupos que interagem com os metais são os mesmos grupos das amostras de ácido húmico sem adição de metal. Enquanto que para os ácidos fúlvicos observou-se uma maior diferenciação estrutural uma vez que ao interagir com os metais $\mathrm{Cu}$ (II) e $\mathrm{Al}$ (III) nessas amostras de solos houve o aparecimento de mais duas Componentes que estaram escondidos porque não solicitados.

Os Componentes A, C, D e E exibiram maiores intensidades de fluorescência para região do azul, caracterizando grupos fluorescentes de caráter mais alifáticos, já os Componentes B e F apresentaram maiores intensidades de fluorescência para região do vermelho, caracterizando grupos fluorescentes com características mais aromáticas. Assim, as descrições das Componentes são: letra A: atribui-se ao pico A, tipicamente húmico; letra B: refere-se a picos de baixa energia que são conhecidos por ser tipicamente de ácido húmico terrestre; letra $C$ : referem-se aos picos A e C, que são caracteríticos de substâncias húmicas provenientes de ambientes terrestres, sendo o pico A, tipicamente fúlvico, e o pico $\mathrm{C}$, tipicamente húmico; letras $D$ e F: refere-se ao pico $\mathrm{D}$ presente em ácidos fúlvicos de solos; letra E: refere-se ao pico da proteína do triptofano, também conhecida como "protein like", composto de atividade microbiana recente (Coble, 1996; Matthews et al., 1996; Stedmon et al., 2003; Coble et al., 2014).

As Componentes variaram dependendo do Perfil estudado. Assim, a Tabela 5.III.18, apresenta a ordem em que cada Componente apareceu nos Espodossolos Amazônico para os metais empregados. Conforme exibido na Tabela 5.III.18, os Componentes dos ácidos húmico foram os representados pelas letras A e B, e não houve variação com o Perfil em relação aos íons analisados.

Nas amostras de ácido fúlvico verificou-se uma variação com o Perfil, em que os Espodossolos hidromórficos (P1 e P3) os Componentes responsáveis pela Fluorescência nas amostras foram os representados pelas letras C e E (Tabela 5.III.18) para ambos os metais pesquisados. Já as Componentes C e D estão presentes nos Espodossolos hidromórfico (P1) e as Componentes C e F estão presentes nos Espodossolo bem drenado (P4) (Tabela 5.III.18). 
Tabela 5.III.18: Componentes obtidas pelo CP/PARAFAC para cada Perfil de Espodossolos Amazônico com os íons $\mathrm{Cu}$ (II) e $\mathrm{Al}$ (III).

\begin{tabular}{c|c|c|c|c}
\hline \multicolumn{5}{c}{ Cu (II) e Al (III) } \\
\hline \multirow{2}{*}{ Perfil } & \multicolumn{2}{|c}{ Ácido Húmico } & \multicolumn{2}{c}{ Ácido Fúlvico } \\
\cline { 2 - 5 } & Componente 1 & Componente 2 & Componente 1 & Componente 2 \\
\hline P1 & A & B & C & D \\
P2 & A & B & C & E \\
P3 & A & B & C & F \\
P4 & A & B & C & E \\
\hline
\end{tabular}

Fonte: Autoria Própria.

Além disso, nesse estudo foram avaliados dois tipos de modelos de interações entre os metais, o modelo 1:1 $(\mathrm{a}=\mathrm{b}=1)$ e modelo 1:2 $(\mathrm{a}=1$ e $\mathrm{b}=2)$. Para uma melhor discussão dos resultados obtidos, avaliou-se qual dos modelos se enquadraram para as frações húmicas com os metais $\mathrm{Cu}$ (II) e $\mathrm{Al}$ (III). Para isto, avaliou-se o BIAS, parâmetro que se refere à probabilidade de acerto do modelo proposto. A Figura 5.II.61, apresenta o BIAS obtidos para os modelos 1:1 (Figura 5.III.61a) e 1:2 (Figura 5.III.61b) da interação dos AH e AF com o metal $\mathrm{Cu}$ (II).

Figura 5.III.61: Comparações dos BIAS dos modelos: (a) 1:1 e (b) 1:2 com o metal Cobre (II).

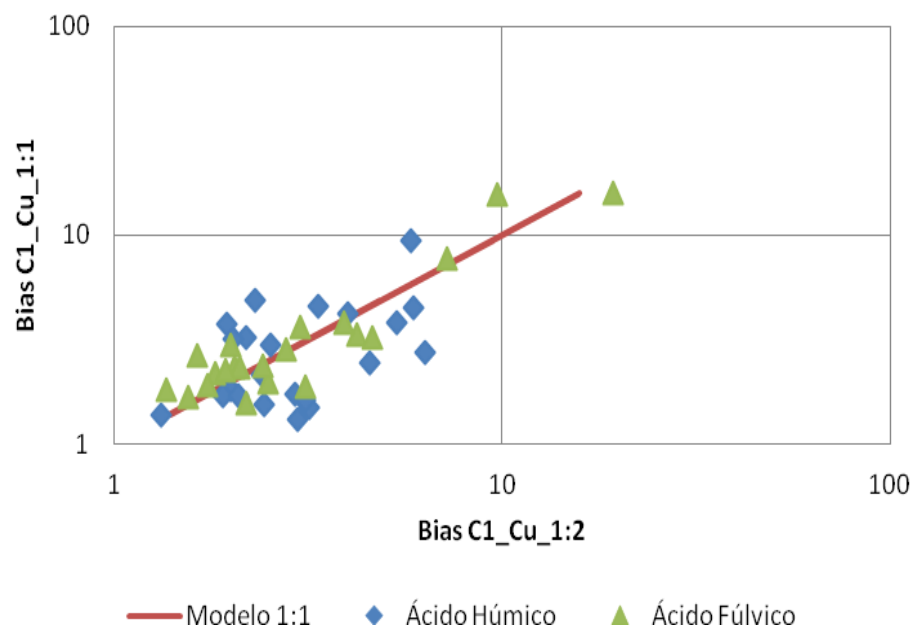

(a)

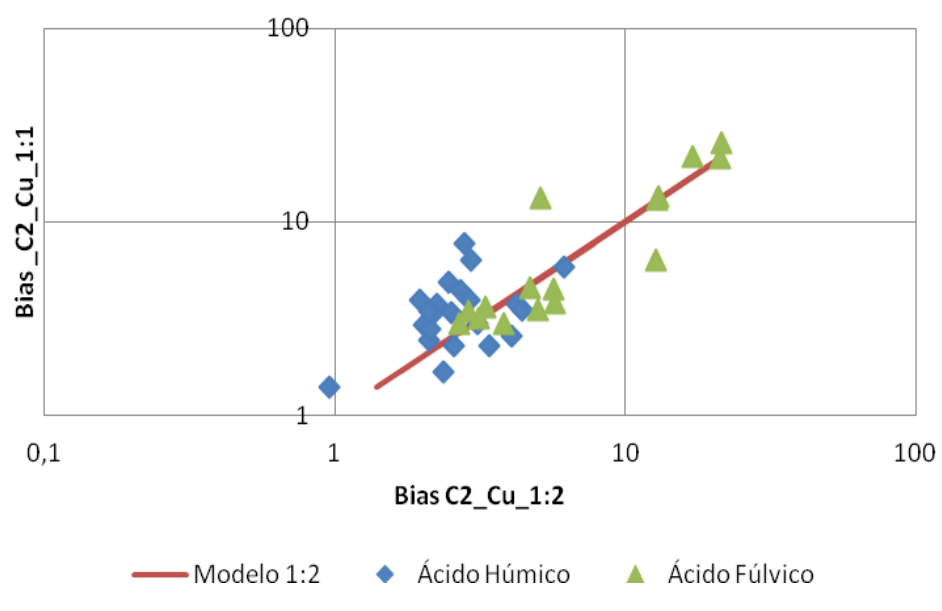

(b)

Fonte: Autoria Própria.

Conforme observado na Figura 5.III.61, não houve diferença entre os dois modelos quando avaliados os BIAS para ambos os modelos, porém o modelo 1:1 mostrou menores valores de BIAS para maioria das frações de ácido húmico e fúlvico. Desde modo, nesse 
estudo da interação do metal $\mathrm{Cu}$ (II) com as frações húmicas assumiu-se como melhor modelo o 1:1. Após assumir o modelo 1:1 avaliaram-se as constantes de estabilidade condicional obtidas para esse modelo empregando as Componentes, $\mathrm{C} 1$ e $\mathrm{C} 2$ obtidas pelo CP/PARAFAC. Este resultado está apresentado na Figura 5.III.62.

Figura 5.III.62: Avaliação da Constante de Estabilidade do Cu (II) com os ácidos húmico e ácidos fúlvico para o modelo $1: 1$.

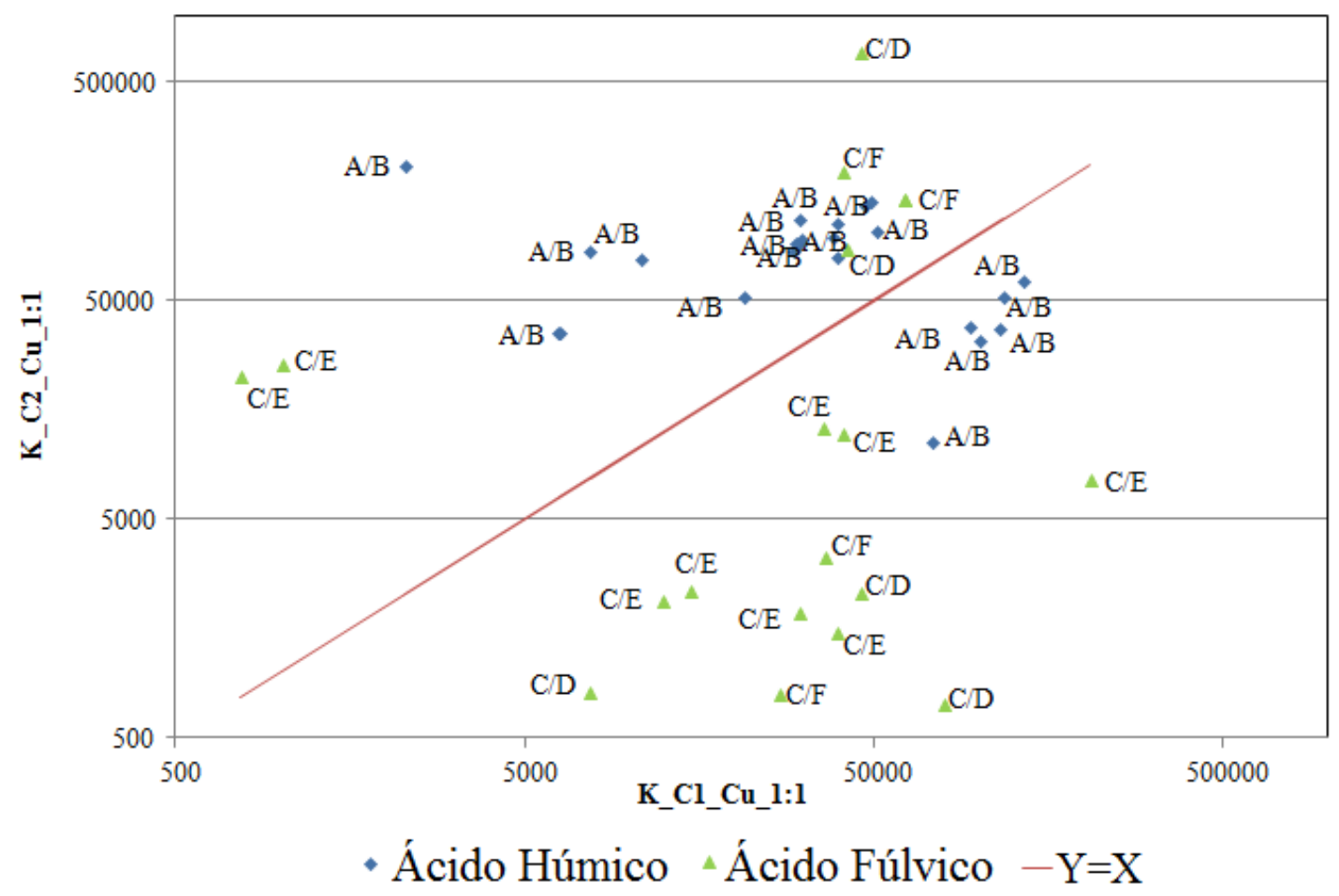

Fonte: Autoria Própria.

Na Figura 5.III.62 verifica-se que as amostras de ácido fúlvico na sua maioria apresentaram maiores valores de constante de estabilidade $(\mathrm{K})$ para o Componente 1 do CP/PARAFAC. Refere-se a uma molécula com estruturas mais simples as quais podem estar relacionadas aos Componentes descritos no gráfico "C/E" e "C/D", e ao correlacionar a Tabela 5.III.17 (página 125), pode correlacionar a Componente C dos AF (componente com emissão mais para região do azul, favorecendo grupos mais alifáticos). Nas amostras de ácido húmico (Figura 5.III.62) observou-se comportamento contrário, em que os maiores valores de $\mathrm{K}$ foram para o Componente 2, que se assemelha a estruturas mais complexas com emissão na região do vermelho (referente ao Componente letra “ $B$ ” - Tabela 5.III.17, página 125).

$\mathrm{O}$ mesmo estudo foi realizado empregando o metal Al (III). Para isto, avaliaram-se os BIAS obtidos pelos modelos matemáticos, conforme exibido na Figura 5.III.63. Pode-se observar que o melhor modelo matemático que representa a interação do metal Al (III) com as 
frações húmicas foi o modelo 1:1, visto que o BIAS variou de 1 a 10. Ao comparar esse BIAS com o BIAS do $\mathrm{Cu}$ (II) (Figura 7.61 (a)), os valores obtidos pelo metal Al (III) foram muito menores.

Figura 5.III.63: Comparações dos BIAS dos modelos: (a) 1:1 e (b) 1:2 com o metal Al (III).

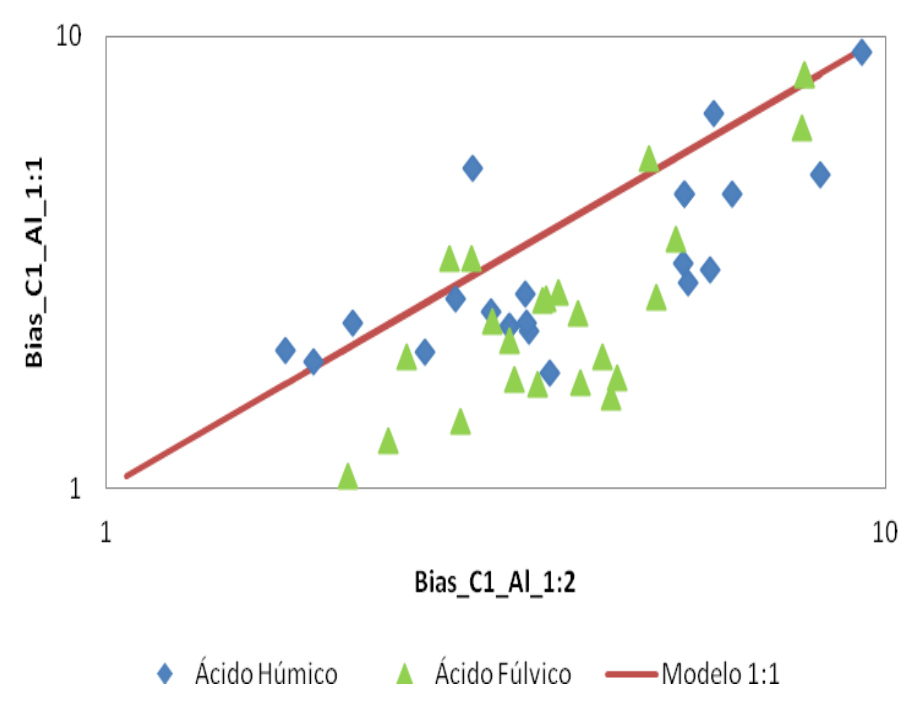

(a)

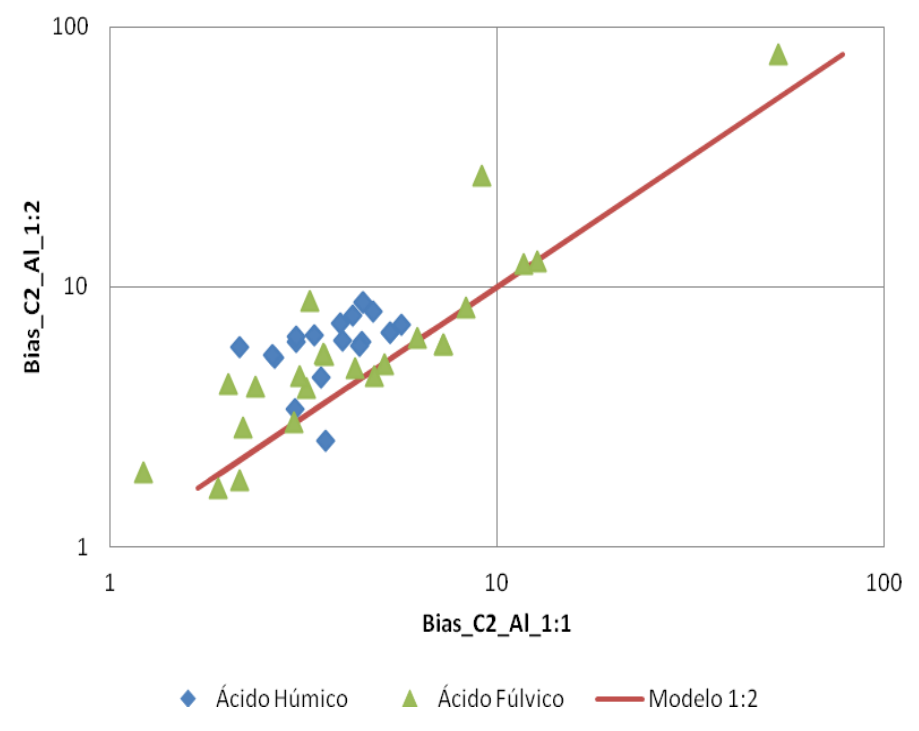

(b)

Fonte: Autoria Própria.

A Figura 5.III.64 exibe o comportamento obtido da constante de estabilidade para o metal Al (III) com as frações húmicas. Os ácidos fúlvicos apresentaram maiores valores de constante de estabilidade $(\mathrm{K})$ para o Componente 1 quando comparado aos ácidos húmicos em que não houve muita diferenciação entre os Componentes, C1 e C2.

Na Figura 5.III.64 mostra que os maiores valores de constante de estabilidade foram para as amostras de ácido fúlvico para o Componente 1, especialmente para os Componentes representados pelas letras “ $C / E$ ” e “ $C / F$ ” (Tabela 5.III.17, página 125), cujas características referem-se os compostos com estruturas mais alifáticas, as quais emitem fluorescência na região do azul. Já as amostras de ácido húmico apresentaram menores valores de K quando comparados aos ácidos fúlvicos, e as constantes de estabilidade foram maiores nos ácidos húmicos para o Componente 2, e ao verificar o Componente 2 pode ser associado a estruturas mais aromáticas, tais como o Componente representado pela letra “ $B$ ” (Tabela 5.III.17). 
Figura 5.III.64: Avaliação da constante de estabilidade do Al (III) com os ácidos húmico e ácidos fúlvico para o modelo $1: 1$.

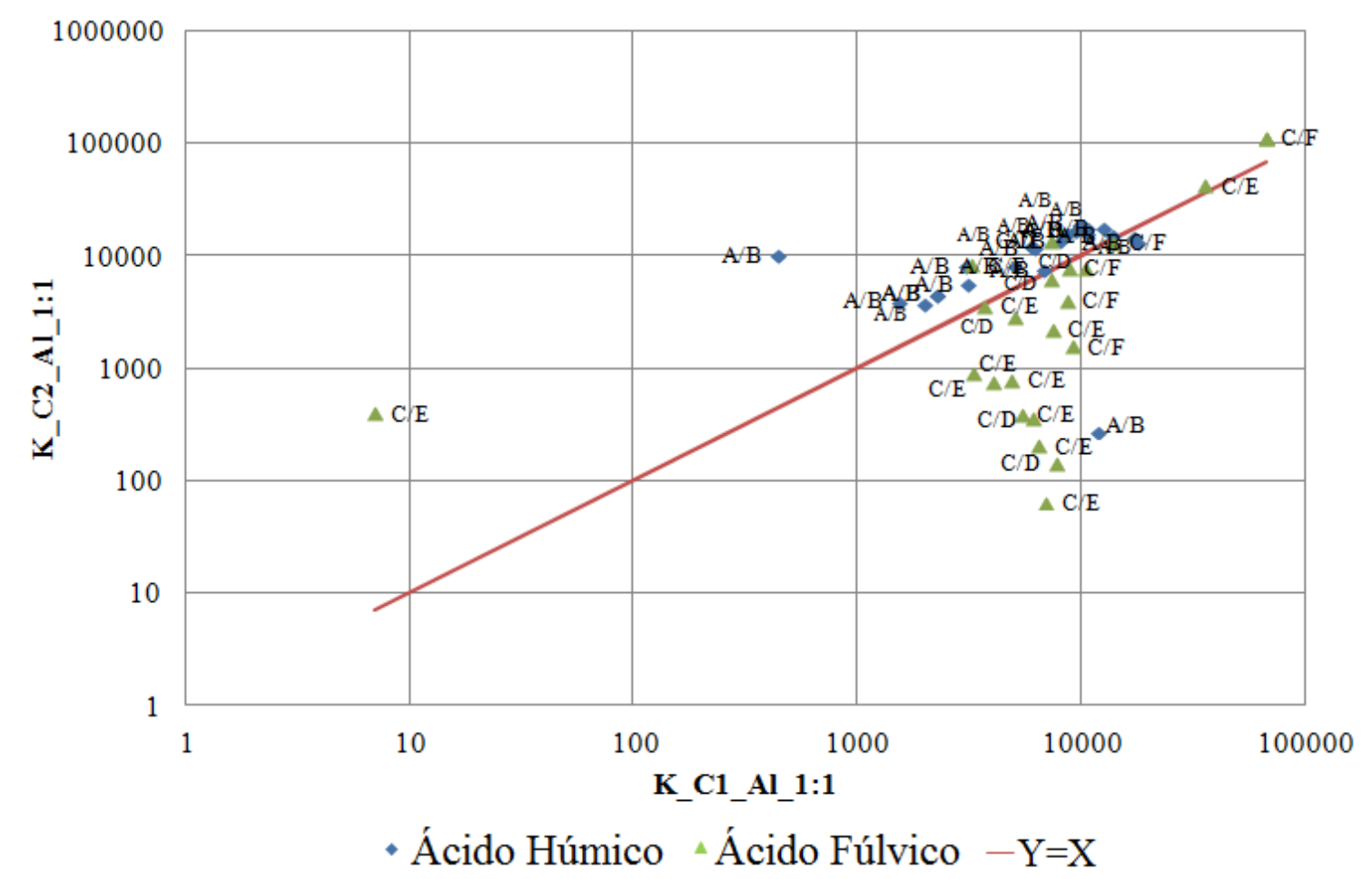

Fonte: Autoria Própria.

A quantidade de sítios capazes de complexar o metal foi avaliada através do parâmetro denominado capacidade de complexação (CL) para ambas Componentes, C1 e C2. A Figura 5.III.65 apresenta as CL dos íons metálicos, $\mathrm{Cu}$ (II) e Al (III). Os maiores valores das CL dos Componentes foram obtidos para as amostras de ácido fúlvico. Realizando a média das CL dos ácidos húmicos e fúlvicos o metal $\mathrm{Cu}$ (II) têm-se: $4,06 \mathrm{E}^{-10}$ e $3,69 \mathrm{E}^{-9}$ sítio de complexação $\mathrm{mg}^{-1}$ de $\mathrm{AH}$, respectivamente, já para o metal $\mathrm{Al}$ (III) obtiveram-se: $3,19 \mathrm{E}^{-10}$ e $3,75 \mathrm{E}^{-9}$ sítio de complexação $\mathrm{mg}^{-1}$ de AF.

Conforme observado na Figura 5.III.65, os sítios de complexação dos íons de Cu (II) e $\mathrm{Al}$ (III) tem comportamentos semelhantes, pois a maioria dos horizontes está agrupada na região de $4 \mathrm{E}^{-10}$ e $5 \mathrm{E}^{-9}$ sítio de complexação $\mathrm{mg}^{-1}$ de $\mathrm{AH}$ ou $\mathrm{AF}$ considerandos os BIAS para cada amostra. Portanto, podemos verificar que a Capacidade de Complexação relativa ao Carbono das amostras de ácido húmico é 10 vezes menor que a CL dos ácidos fúlvicos, ou seja, os ácidos húmicos precisam 10x mais carbono em sua estrutura para ter o mesmo poder de complexar que os ácidos fúlvicos apresentaram nesses horizontes. Assim, as amostras de ácidos fúlvicos tem a capacidade de complexar mais em relação ao número de carbono, pois 
esta fração possui maiores sítios de complexação para interagir com os íons metálicos Cu (II) e $\mathrm{Al}$ (III).

Figura 5.III.65: Comparação entre as CL (CL1+CL2) dos ácidos húmicos vs dos ácidos fúlvicos para os íons Cu (II) (destacado em vermelho) e os íons Al (III) (destacado em azul) com os BIAS nas barras de erros de cada horizonte.

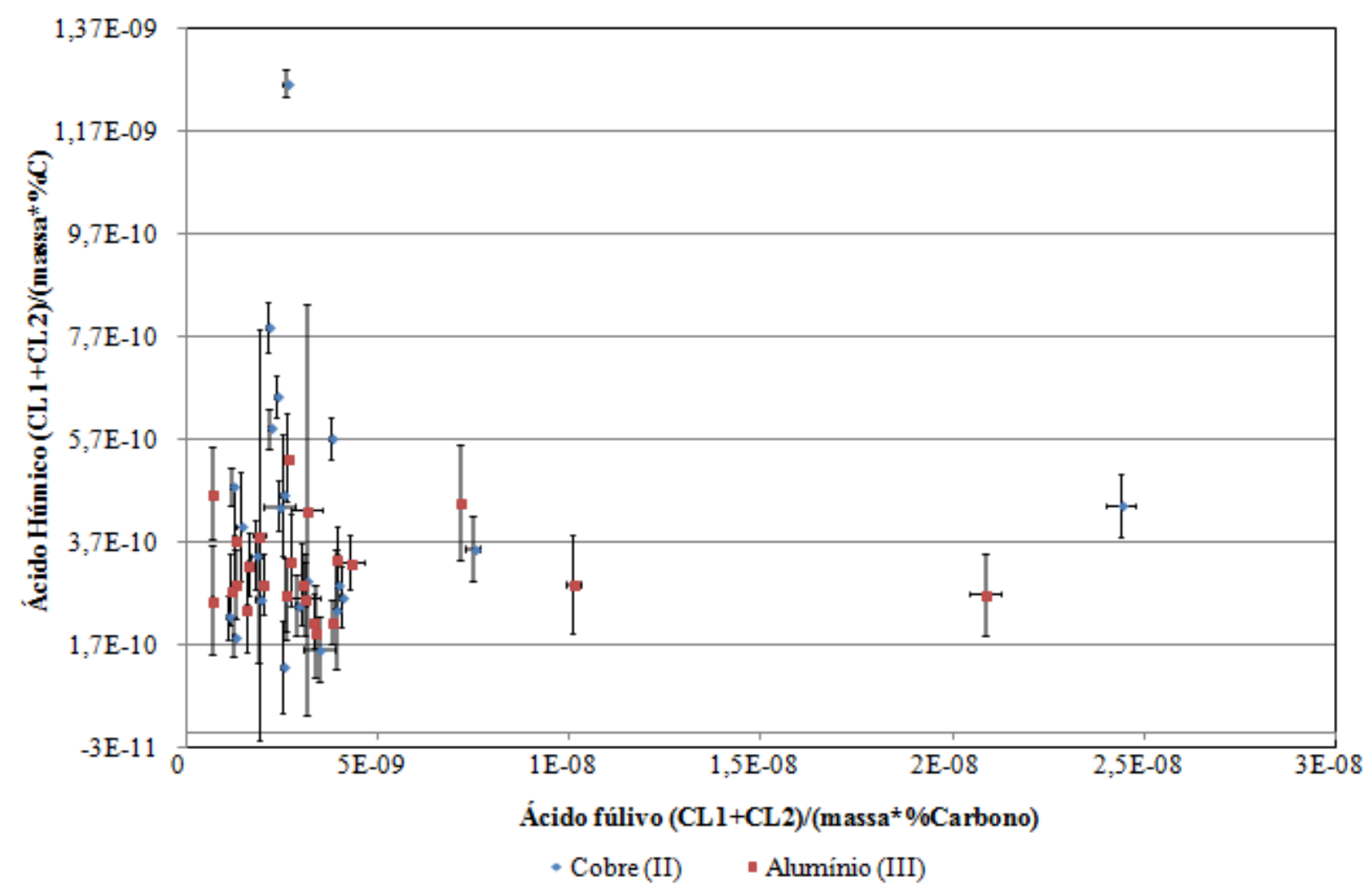

A Figura 5.III.66, apresenta a correlação entre os sítios de complexação dos íons $\mathrm{Cu}$ (II) vs Al (III) para as frações húmicas dos perfis avaliados. Pode-se observar que as amostras de ácido húmico apresentaram maior espalhamento para os íons Al (III). Demonstrando assim, uma maior especificidade para esse metal, enquanto que para os ácidos fúlvicos não há variação entres os metais analizados, ou seja, a concentração de sítios de complexação tem à mesma proporção entre os íons metálicos estudados. 
Figura 5.III.66: Correlação entre a Capacidade de Complexação (CL1+CL2) dos íons Al (III) vs Cu (II) para os Espodossolos Amazônico.

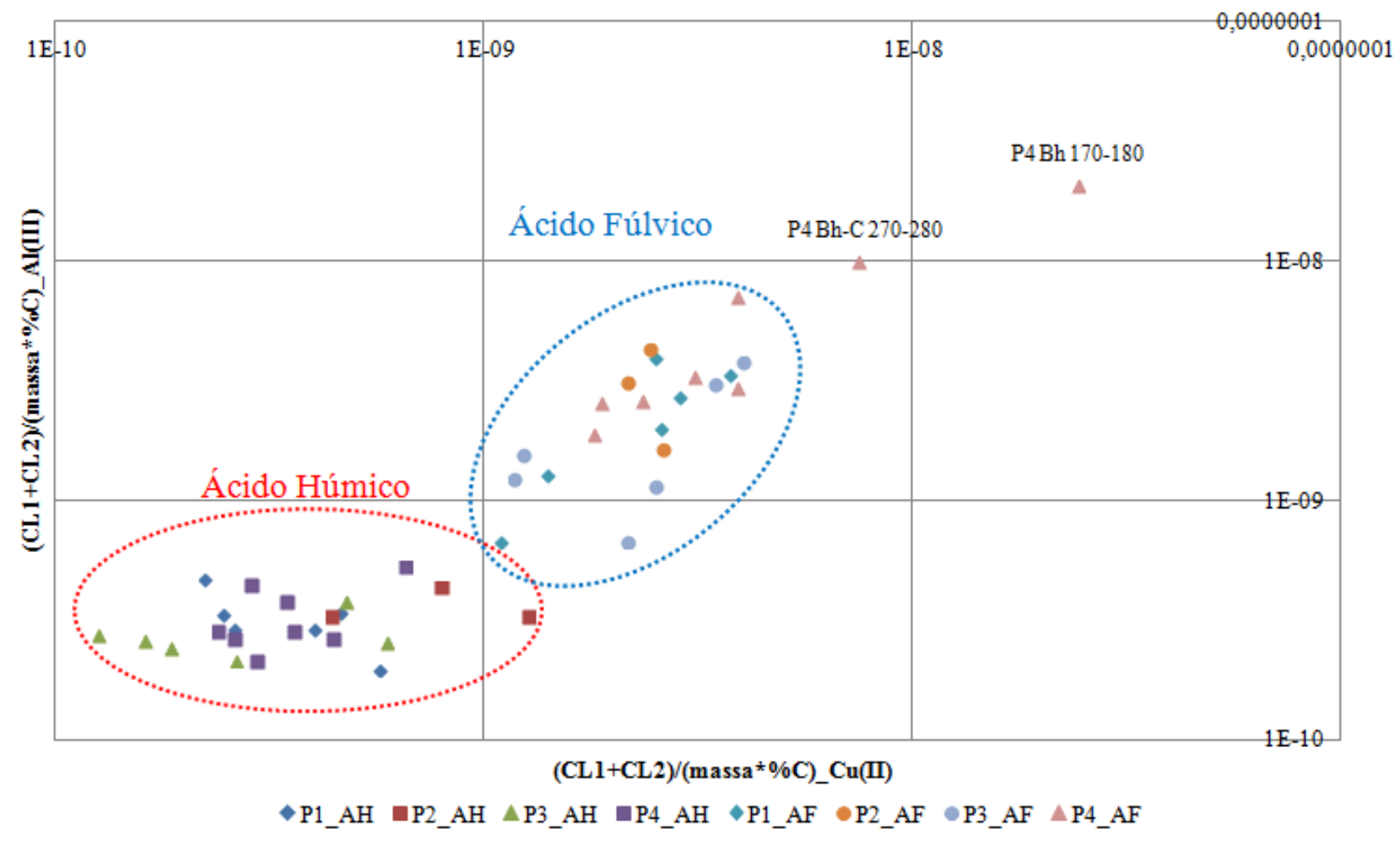

Fonte: Autoria Própria.

Afim, de finalizar o tratamento realizado nesses resultados, empregou-se a Analise de Componentes Principais (ACP) das amostras de perfis (Figura 5.III.67). A Figura 5.III.67 pode-se observar uma boa separação das frações húmicas. Os ácidos húmicos estão mais agrupados, enquanto que os ácidos fúlvicos encontram-se mais espalhados, e essa separação ocorre por influência da capacidade de complexação, ou seja, os ácidos húmicos se agrupa em direção do menor valor de capacidade de complexação. Além disso, pode-se observar uma melhor separação por perfil para as amostras de ácidos fúlvicos, e que alguns horizontes Bh dos AF apresentam características distintas, e são mais afastados correspondendo aos perfis P4 e P3. 
Figura 5.III.67: Análise de Componentes Principais (ACP) dos resultados da análise de quenching das amostras de ácidos húmicos e fúlvicos representado por perfis.

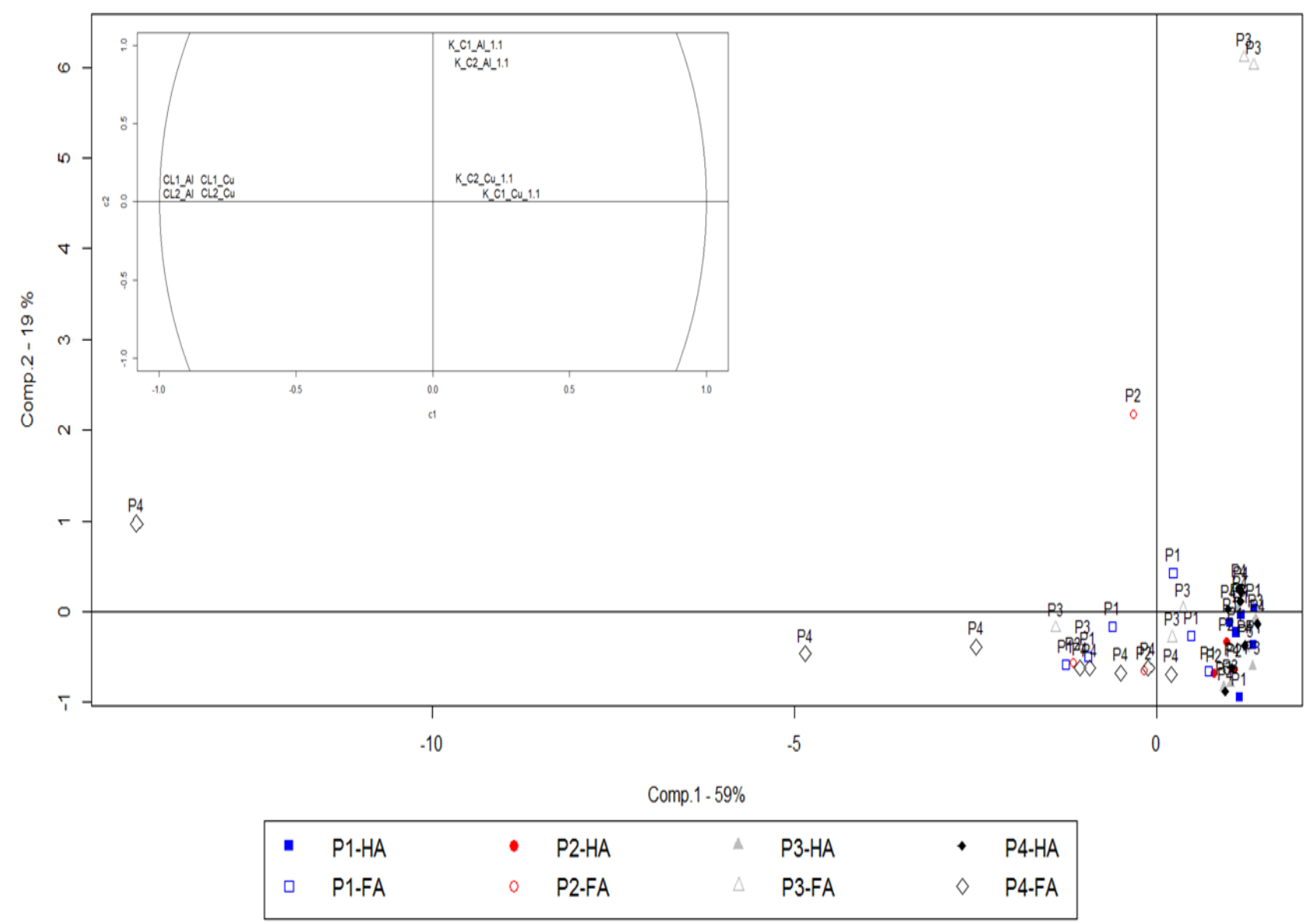

Fonte: Autoria Própria.

Portanto, os resultados da análise de quenching mostraram que as frações húmicas obtiveram como melhor modelo o 1:1 para os íons $\mathrm{Cu}$ (II) e $\mathrm{Al}$ (III). Em relação aos resultados das componentes conclui-se que os ácidos húmicos apresentaram apenas duas componentes que não variaram com o perfil, enquanto que para as amostras de ácido fúlvico observou-se uma maior variação. O Componente 1 para os metais $\mathrm{Cu}$ (II) e $\mathrm{Al}$ (III) representam mais um Componente típico húmico que complexa mais que o Componente 2 para as amostras de ácido húmico. Os ácidos húmicos apresentaram menores quantidades de sítios de complexação que as amostras de ácidos fúlvicos para ambos os metais estudados. Além disso, a constante de estabilidade para amostras de ácidos húmicos foram muito maiores que para amostras de ácidos fúlvicos.

Foi realizada uma nova ACP emglobando os resultados obtidos pela análise de quenching com as análises espectroscópicas, tais como FTIR, UV-Vis e Fluorescência Molecular, e está exibido na Figura 5.III.68. 
Figura 5.III.68: Análise de Componentes Principais (ACP) dos resultados da análise de quenching das amostras de ácidos húmicos e fúlvicos representado por parâmetros e perfis.

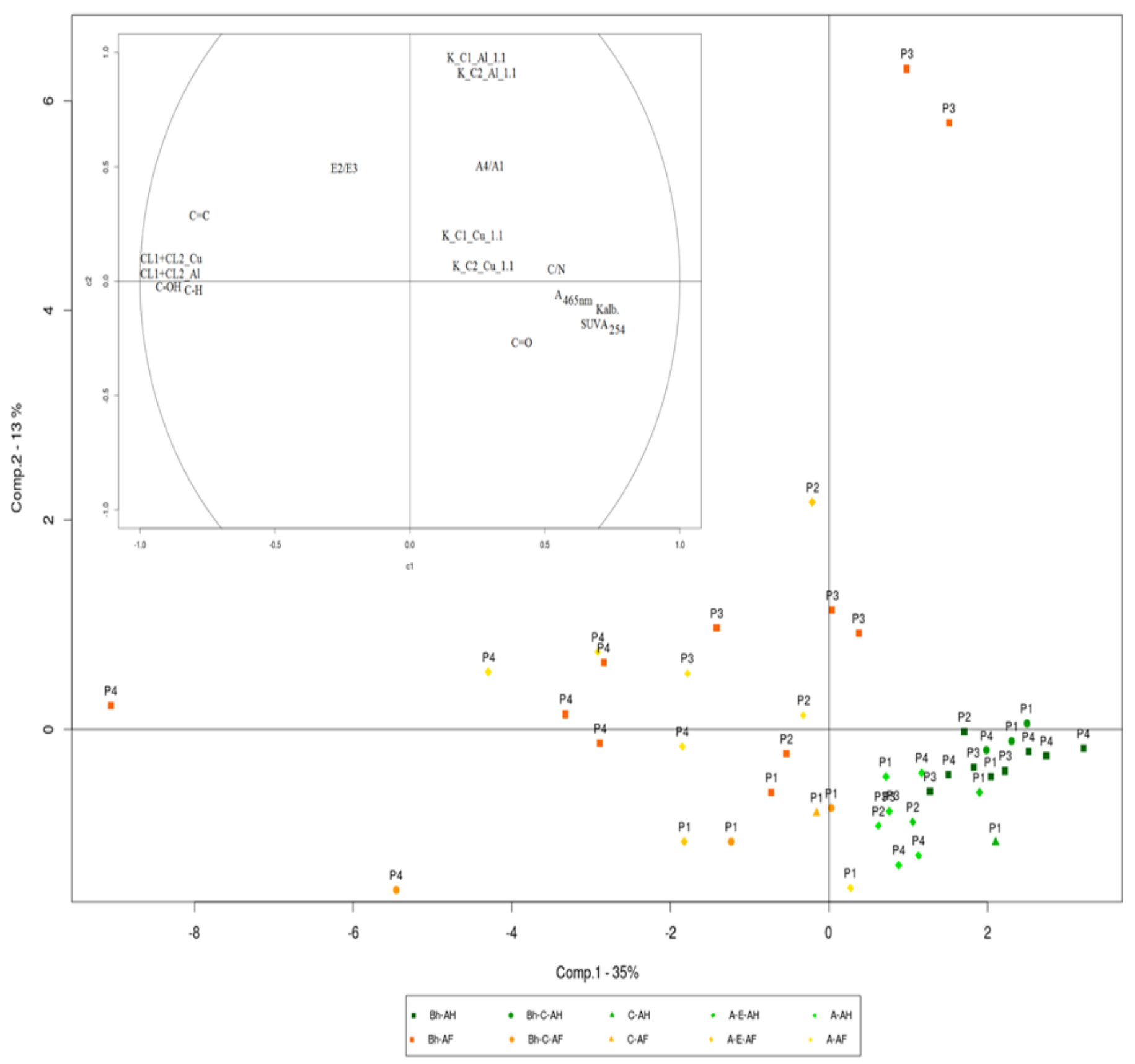

Fonte: Autoria própria.

Na Figura 5.III.68, as capacidades de complexação para os metais Cu (II) e Al (III) vão no mesmo sentido que os grupos hidroxilas $(\mathrm{C}-\mathrm{OH})$, alifáticos $(\mathrm{C}-\mathrm{H})$ e carboxílicos $(\mathrm{C}=\mathrm{C})$ obtidos pelos FTIR, enquanto que constante de estabilidade para o íon $\mathrm{Cu}$ (II) estão no sentido oposto juntamente com os índices de humificação propostos por Kalbitz et al (1999) e Milori et al. (2002), bem como $\mathrm{SUVA}_{254 \mathrm{~nm}}, \mathrm{C} / \mathrm{N}$ e carbonilas $(\mathrm{C}=\mathrm{O})$. Demonstrando assim, que os ácidos fúlvicos apresentaram maiores capacidades de complexação e têm 
características mais alifáticas quando comparados aos ácidos húmicos que possuem características mais aromáticas. Os grupos funcionais $\mathrm{C}=\mathrm{O}$ e $\mathrm{C} / \mathrm{N}$ são parâmetros que influenciam diretamente a $\mathrm{KCu}$ (II), o que permite estar associado a especificidade da complexação e uma maior interação com esses grupos funcionais especialmente para os ácidos húmicos. Enquanto que o índice de humificação $\mathrm{A}_{4} / \mathrm{A}_{1}$ e a razão $\mathrm{E}_{2} / \mathrm{E}_{3}$ estão no mesmo sentido que a constante de estabilidade para o metal Al (III), e que influenciaram na separação dos horizontes Bh, P3 Bh 180-183 e P3 Bh 210 (Figura 5.III.68). Os horizontes Bh dos ácidos húmicos possuem uma maior complexação com o metal Al (III) quando comparado aos outros horizontes, e esse comportamento não é observado para as amostras de ácido fúlvico. Além disso, pode-se verificar que há uma boa separação entre os ácidos húmicos e fúlvicos pelos horizontes, enquanto que a separação pelo perfil foi verificada apenas para os ácidos fúlvicos.

\section{III.2. Considerações parciais}

As frações húmicas do Espodossolos Amazônico mostraram que o modelo 1:1 é o melhor modelo para avaliar a interação com os íons cobre (II) ou alumínio (III). Em relação aos resultados das componentes, podemos concluir que os AH e AF apresentaram duas componentes pelo CP/PARAFAC, entretanto elas eram diferentes.

As amostras de ácido fúlvico mostraram uma maior interação com $\mathrm{Al}$ e $\mathrm{Cu}$ no perfil, sugerindo uma diferença estrutural dessa fração em relação ao AH. A interação das frações húmicas dos Espodossolos Amazônico com os íons $\mathrm{Cu}$ (II) e $\mathrm{Al}$ (III) mostrou que os ácidos húmicos apresentaram menores quantidades de sítios de complexação e uma menor constante de estabilidade quando comparados aos ácidos fúlvicos. Os ácidos fúlvicos apresentaram maior capacidade de complexação, que podem estar associado a sua estrutura química mais simples, que possibilita uma maior seletividade de interação com esses metais. Entretanto, os ácidos húmicos apresentaram uma estrutura mais complexa a sua seletividade por metais foi menor, conforme determinado pela baixa capacidade de complexação. 
Capítulo 6-Conclusão 
No Espodossolo hidromórfico (P1) observou-se um grande acúmulo de material orgânico fresco e de baixa humificação na superfície. Aparentemente as frações mais humificadas são translocadas no perfil e acumulam-se em profundidade. A disponibilidade de água em todo o perfil aumentou a mobilidade da MO, proporcionando este acúmulo.

No Espodossolo hidromórfico (P2) também verficou-se um acúmulo de carbono em horizontes mais profundos. Porém, neste caso a MO era pouco humificada. A quantidade de carbono e o índice de humificação podem estar sendo afetados pelo nível do lençol freático, principalmente nos perfis P1, P2 e P3 que sofrem ação direta do lençol freático suspenso. Além disso, pode haver um transporte horizontal de carbono pelo movimento das águas subterrâneas e um movimento vertical descendente causado pelo alto índice pluviométrico que ocorre a partir da superfície para os horizontes mais profundos.

O Espodossolo hidromórfico (P3), corresponde a um perfil interessante, pois foi verificado um horizonte impermeável em P3 Bh 180-183, em que há presença de uma matéria orgânica de baixa humificação e relativamente antiga. Enquanto que o horizonte abaixo em P3 Bh 210 tem um material orgânico muito humificado e muito antigo. Esse material orgânico humificado e extremamente antigo foi oxidado e com o auxílio do lençol freático suspenso foi deslocado em forma de moléculas mais solúveis de tamanho molecular menor e mais humificado para os horizontes Bh mais profundos, conforme verificado nos horizontes P3 Bh 280- 310 e P3 Bh 335-350 que obtiveram altos índices de humificação.

No Espodossolo bem drenado (P4), verificou-se que os maiores valores de carbono foram nos horizontes superficiais e o índice de humificação aumentou com a profundidade até $280 \mathrm{~cm}$ (P4 Bh 270-280). Abaixo desse horizonte P4 Bh 270-280 foi observado um material orgânico de baixa humificação, que pode estar associado à presença de compostos mais recalcitrantes de origem lignítica. Os compostos orgânicos do tipo lignina parecem ser preservados por muitos anos nos horizontes mais profundos desses solos.

De forma geral, foi possível verificar a existência de quatro grupos de matéria orgânica: recalcitrante, humificada e antiga; lábil e jovem; pouco humificada e antiga; e por fim humificada e jovem. Os fatores como textura, presença de água e microorganismos influenciaram nos processos de formação e humificação desse material orgânico. Assim, o processo de humificação não tem relação direta com a datação da matéria orgânica nesses solos.

De forma geral, os ácidos fúlvicos demonstraram ter uma contribuição oriunda de lençóis freáticos, cuja estrutura química varia pouco com o perfil do solo. Além de possuir maior seletividade na interação com os metais presentes nesses solos, especialmente com o 
metal Al. Em contrapartida, os ácidos húmicos, mostraram-se menos seletivos, pois apresentaram associação com vários tipos de metais, como K, Fe, Mg, Zn e Al. Além de possuir uma estrutura química que varia com o perfil do solo. Devido à diversidade de metais que os $\mathrm{AH}$ têm afinidade, eles devem ser os responsáveis pela fertilidade do solo, e estar diretamente ligados a maior interação com os constituintes do solo. Enquanto que os AF possuem uma maior mobilidade e interação com a água. Portanto, os resultados apresentados nessa Tese, mostraram que os AH e AF participam diretamente no processo de formação desses solos.

Sendo assim, este trabalho propõe o seguinte modelo para o processo de formação destes Espodossolos: o alto aporte de resíduos vegetais e animais passam por um processo de decomposição e são translocados pelo perfil por meio do movimento vertical (altos índices pluviométricos) e horizontal (lençol freático). A transformação dos resíduos em ácidos orgânicos resultam em uma diminuição do $\mathrm{pH}$ do solo, o que começa a desestabilizar as argilas. Os AF tendem a se ligar preferencialmente com o Al, enquanto que os AH se ligam com diversos metais. A presença de água aumenta a mobilidade destes ácidos complexados, que acabam por se acumular em profundidade. Em alguns perfis a presença de lençóis suspensos ou impermealização podem levar a condições favoráveis ou não da decomposição e/ou oxidação da MO. Isso acaba gerando acúmulos diferenciados, às vezes, com matéria orgância jovem e muito degradada e, em outros casos de matéria orgânica antiga com característica de lignina. Outro ponto importante foi observado que as frações húmicas solúveis possuem basicamente quatro fluoróforos. Dois tipicamente presentes nos $\mathrm{AH}$ e dois tipicamente presentes nos AF. Entretanto, a proporção destes fluorófos nos AH e AF variam no perfil, sugerindo que estes ácidos não possuem uma estrutura química bem definida, e sim parecem se estruturar de forma diferenciada a partir das condições de cada horizonte de solo. Os dados obtidos neste trabalho validam a hipótese de que as $\mathrm{SH}$ são formadas em processos de decomposição, agregação de fragmentos orgânicos e complexação com metais. Esses processos devem ser em função da textura, do $\mathrm{pH}$, da disponibilidade de água e dos microorganismos presente no solo. Portanto, essa matéria orgânica com estrutura mais simples e com maior mobilidade pode impactar muito a forma que encaramos o acúmulo de carbono no solo e sua estabilidade, pois esse modelo o carbono armazenado em solo Amazônico é mais suceptível à decomposição. Assim, a conservação desses solos torna-se fundamental para evitar grandes fluxos de emissão de carbono por exposição de perfis profundos ou alteração do regime de chuvas, impondo prolongados períodos de seca e aumentando atividade microbiológica do solo, e consequentemente emissão de $\mathrm{CO}_{2}$. 
Capítulo 7 - Referências Bibliográficas 
ABATE, G. Isolamento, purificação e estudo de complexação de substâncias húmicas. 1998. 119 f. Dissertação (Mestrado em Química Analítica) - Instituto de Química, Universidade de São Paulo, São Paulo, 1998.

ABBT-BRAUN, G.; LANKES, U.; FRIMMEL, F.H. Structural characterization of aquatic humic substances: the need for a multiple method approach. Aquatic Science, v. 66, p. 151$170,2004$.

ALBERTS, J.J.; TAKÁCS, M. Total luminescence spectra of IHSS standard and reference fulvic acids, humic acids and natural organic matter: comparison of aquatic and terrestrial source terms. Organic Geochemistry, v. 35, p. 243-256, 2004.

ALLARD, B. A comparative study on the chemical composition of humic acids from forest soil, agricultural soil and lignite deposit Bound lipid, carbohydrate and amino acid distributions. Geoderma, v. 130, p. 77-96, 2006.

ALMENDROS, G.; GUADALIX, M.E.; GONZÁLEZ-VILA, F.J.; MARTIN, F. Preservation of aliphatic macromolecules in soil humans. Organic Geochemistry, v. 24, p. 651-659, 1996.

ARAÚJO, A.B.; ROSA, A.H.; ROCHA, J.C.; ROMÃO, L.P. Distribuição de metais e caracterização das constantes de troca entre espécies metálicas e frações húmicas aquáticas de diferentes tamanhos moleculares. Química Nova, v. 25, p. 1103-1107, 2002.

ASSOCIAÇÃO BRASILEIRA DE NORMAS TÉCNICAS (ABNT). NBR 6502: rochas e solos: terminologia. Rio de Janeiro, 1995. 18p.

AZEVEDO, J.C.R; NOZAKI, J. Análise de fluorescência de substancias húmicas extraídas da água, solo e sedimento da Lagoa dos Patos - MS. Química Nova, v. 31, p. 1324-1329, 2008.

BARDY, M.; FRITSCH, E.; DERENNE, S.; ALLARD, T.; DO NASCIMENTO, N.R.; BUENO, G.T. Micromorphology and spectroscopic characteristics of organic matter in waterlogged podzols of the upper Amazon basin. Geoderma, v. 145, p. 222-230, 2008.

BAYER, C.; MARTIN-NETO, L.; MIELNICZUK, J.; CERETTA, C. A. Effect of no-till cropping system on soil organic matter in a sandy clay loam Acrisol from Southern Brazil monitored by electron spin resonance and nuclear magnetic resonance. Soil Tillage

Reseource, v. 53, p. 95-104, 2000.

BENITES, V.M.; MADARI, B.; MACHADO, P.L.O.A. Extração e fracionamento quantitativo de substâncias húmicas do solo: um procedimento simplificado de baixo custo. Rio de Janeiro: Embrapa Florestas, 2003. 7 p. (Comunicado Técnico).

BISPO, N.B. Seleção de genótipos e análise da tolerância do milho (Zea mays L.) ao encharcamento do solo. 2011. 78 f. Tese (Doutorado em Fitotecnia) - Faculdade de Agronomia, Universidade Federal do Rio Grande do Sul, Porto Alegre, 2011.

BOGUTA, P.; D’ORAZIO, V.; SOKOŁOWSKA, Z.; SENESI, N. Effects of selected chemical and physicochemical properties of humic acids from peat soils on their interaction mechanisms with copper ions at various pHs. Journal of Geochemical Exploration, v. 168, p. 119-126, 2016.

BOT, A.; BENITES, J. The importance of soil organic matter: key to drought-resistant soil and sustained food production. Food and Agriculture Organization of the United Nations. Rome, 2005. 95 p. 
BOULET, R.; CHAUVEL, A.; HUMBEL, F. X.; LUCAS, Y. Analyse structurale et cartographie en pédologie: I - Prise en compte de 1'organisation bidimensionelle de la couverture pédologique: les études de toposéquences et leurs principaux apports à la connaissance dês sols. Séries Pédologie, v. 19, n. 4, p. 309-321, 1982.

BRASIL. Ministério de Minas e Energia, Departamento Nacional de Produção Mineral (RADAMBRASIL). Levantamento de recursos naturais. Rio de Janeiro, 1978. v. 1

BRASIL. Ministério do Meio Ambiente (MMA). Mapa de cobertura vegetal. Brasília, 2013. Disponível em: <http://www.mma.gov.br/biomas/amaz\%C3\%B4nia/mapa-de-coberturavegetal>. Acesso em 27 jun. 2014.

BRAVARD, S.; RIGHI, D. Geochemical differences in an oxisolspodosol toposequence of Amazonia (Brazil). Geoderma, v. 44, p. 29-42, 1989.

BUFFLE, J. Characteristics of aquatic organic compounds. In: BUFFLE, J. Complexation reactions in aquatic systems an analytical approach. New York: Ellis Horwood, 1990. p. 427.

BURGUES, A.; HURST, H.M.; WALKDEN, S.B.; DEAN, F.M.; HIRST, M. Nature of humic acids. Nature, p. 4894, 1963.

CALACE, N.; PETRONIO, B. M.; PERSIA, S.; PIETROLETTI, M.; PACIONI, D. A new analytical approach for humin determination in sediments and soils. Talanta, v. 71, p. 14441448, 2007.

CASTRO, G.C. Carbono orgânico nas frações granulométricas e húmicas em solos de diferentes texturas sob floresta da região noroeste matogrossense. 2008. 45 f. Dissertação (Mestrado em Ciências Florestais e Ambiental) - Faculdade de Engenharia Florestal, Universidade Federal de Mato Grosso, Cuiabá, 2008.

CERRI, C.C.; BERNOUX, M.; ARROUAYS, D.; FEIGL, B.J.; PICCOLO, M.C. Carbon stocks in soils of the Brazilian Amazon. In: KIMBLE, R.L.J.M., STEWART, B.A. (Ed.). Global climate change and tropical ecosystems. Florida: Boca Raton, 2000. p. 438

CHAPMAN, S.J.; CAMPBELL, C.D.; FRASER, A. R.; PURI, G. FTIR spectroscopy of peat in and bordering scots pine woodland: Relationship with chemical and biological properties.

Soil Biology and Biochemistry, v. 33, p. 1193-1200, 2001.

CHEN, J.; BAOHUA, GU.; EUGENE, J. LEBOEUF.; HONGJUN, P.; SHENG, D.

Spectroscopic characterization of the structural and functional properties of natural organic matter fractions. Chemosphere, v. 48, p. 59-68, 2002.

CHENG, K.L. Separation of humic acid with XAD resins. Mikrochimica Acta, v. 2, p. 389396, 1977.

CHIOU, C.T.; KILE, D.E.; RUTHERFORD, D.W.; SHENG, G.; BOYD, S.A. Sorption of selected organic compounds from water to a peat soil and its humic-acid and humin fractions: potential sources of the sorption nonlinearity. Environmental Science Technology, v. 34, p. 1254-1258, 2002.

COBLE, P.; LEAD, J.; BAKER, A.; REYNOLDS, D.; SPENCER, R. G. M. Aquatic organic matter fluorescence. Cambridge: Cambridge University, 2014. 418 p.

COBLE, P.G. Characterization of marine and terrestrial DOM in seawater using excitationemission matrix spectroscopy. Marine Chemistry, v. 51, p. 325-346, 1996. 
COE, M.T.; MARTHEWS, T.R.; COSTA, M.H.; GALBRAITH, D.R.; GREENGLASS, N.R.; IMBUZEIRO, H.M.A.; LEVINE, N.M.; MALHI, Y.; MOORCROFT, P.R.; MUZA, M.N.; POWELL, T.L.; SALESKA, S.R.; SOLORZANO, L.A.; WANG, J. Deforestation and climate feedbacks threaten the ecological integrity of south-southeastern Amazonia. Philosophical Transactions of the Royal Society B, v. 368, p. 01-55, 2013.

COLLINS, R.N.; SAITO, T.; AOYAGI, N.; PAYNE, T. E.; KIMURA, T.; WAITE, T.D. Applications of time-resolved laser fluorescence spectroscopy to the environmental biogeochemistry of actinides. Journal Environmental Quality, v. 40, p. 731-741, 2011.

CONTE, P.; SPACCINI, R.; SMEJKALOVA, D.; NEBBIOSO, A.; PICCOLO, A. Spectroscopic and conformational properties of size-fractions separated from a lignite humic acid. Chemosphere, v. 69, p. 1032-103, 2007.

DIGNAC, M. F.; KNICKER, H.; KÖGEL-KNABNER, I. Effect of N content and soil texture on the decomposition of organic matter in forest soils as revealed by solid-state CPMAS NMR spectroscopy. Organic Matter, v. 33, p. 1715-1726, 2002.

DOUPOUX, C.; MERDY, P.; MONTES, C.R.; NUNAN, N.; MELFI, A.J.; PEREIRA, O.J.R.; LUCAS, Y. Modelling the genesis of equatorial podzols: age and implications for carbon fluxes. Biogeosciences, v.14, p. 2429-2440, 2017.

EMPRESA BRASILEIRA DE PESQUISA AGROPECUÁRIA (EMBRAPA). Sistema brasileiro de classificação de solos. Brasília, 2006. 306 p.

ENVIRONMENTAL PROTECTION AGENCY (EPA), Method 3052: microwave assisted acid digestion of siliceous and organically based matrices. Washington, 1996. 20 p.

ESTEVES DA SILVA, J.C.G.; MACHADO, A.A.S.C. Characterization of the binding sites for $\mathrm{Al}(\mathrm{III})$ and $\mathrm{Be}(\mathrm{II})$ in a sample of marine fulvic acids. Marine Chemistry, v. 54, p. 293302, 1996.

ESTEVES DA SILVA, J.C.G.; MACHADO, A.A.S.C.; FERREIRA, M.A.; REY, F. Method for the differentiation of leaf litter extracts and study of their interaction with $\mathrm{Cu}$ (II) by molecular fluorescence. Canadian Journal Chemistry, v. 76, p. 1197-1209, 1998.

ESTEVES DA SILVA, J.C.G.; MACHADO, A.A.S.C.; OLIVEIRA, C.J.S. Fluorescence quenching of anthropogenic fulvic acids by $\mathrm{Cu}(\mathrm{II}), \mathrm{Fe}(\mathrm{III})$ and UO22+. Talanta, v. 45, p. 1155-1165, 1998.

ESTEVES, V.I.; OTERO, M.; DUARTE, A.C. Comparative characterization of humic substances from the open ocean,estuarine water and fresh water. Organic Geochemistry, v. 40, p. 942-950, 2009.

FANNING, D.S.; FANNING, M.C.B. Soil: morphology, genesis and classification. New York: John Willey \& Sons, 1989. 395p.

FAVORETTO, C.M.; GONÇALVES, D.; MILORI, D.M.B.P.; ROSA, J.A.; LEITE, W.C.; BRINATTI, A.M.; SAAB, S.D.C. Determinação da humificação da matéria orgânica de um latossolo e de suas frações organo-minerais. Química Nova, v. 31, p. 1994-1996, 2008.

FERNANDES, A.N. Caracterização química e reatividade de substâncias húmicas, solo e turfas. 2007. 149 f. Tese (Doutorado em Química Analítica) - Instituto de Química, Universidade Federal de Santa Catarina, Florianópolis, 2007. 
FERREIRA, E.C.; MILORI, D.M.B.P.; FERREIRA, E.J.; DOS SANTOS, L.M.; MARTINNETO, L.; NOGUEIRA, A.R.D.A. Evaluation of laser induced breakdown spectroscopy for multielemental determination in soils under sewage sludge application. Talanta, v. 85, p. 435-440, 2011.

FILELLA, M.; PARTHASARATHY, N.; BUFFLE J. Humic and fulvic compounds. In: WORSFOLD P.J.; TOWNSHEND, A.; POOLE, C.F. (Ed.). Encyclopedia of Analytical Science. 2. ed. Amsterdam: Elsevier, 2005. v. 4, p. 288-298

FLAIG, W. Biochemical factors in coal formation. In: YON GAERTNER, H.R.; WEHNER, $\mathrm{H}$. (Ed.). Advances in organic geochemistry. Oxford-Braunschweig: Pergamon Press, p. 197-232, 1972. p. 197-232

FONTANA, A. Fracionamento da matéria orgânica e caracterização dos ácidos húmicos e sua utilização no sistema brasileiro de classificação de solos. 2009. 82 f. Tese (Doutorado em Agronomia) - Instituto de Agronomia, Universidade Federal Rural do Rio de Janeiro, Seropédica, 2009.

FONTANA, A. Caracterização química e espectroscópica da matéria orgânica em solo do Brasil. 2006. 70 f. Dissertação (Mestrado em Agronomia) - Instituto de Agronomia, Universidade Federal Rural do Rio de Janeiro, Seropédica, 2006.

FRITSCH, E.; ALLARD, T.; BENEDETTI, M.F.; BARDY, M.; NASCIMENTO, N. R.; LUCAS, Y.; CALAS, G. Organic complexation and translocation of ferric iron in podzols of the Negro River watershed. Separation of secondary Fe species from Al species. Geochimica et Cosmochimica Acta, v. 73, p. 1813-1825, 2009.

FRITSCH, E.; HERBILLON, A.J.; NASCIMENTO, N.R.; GRIMALDI, M.; MELFI, M.J. From Plinthic Acrisols to Plinthosols and Gleysols: iron and groundwater dynamics in the tertiary sediments of the upper Amazon basin. European Journal of Soil Science, v. 58, p. 989-1006, 2007.

FRÖHLICH, D.R.; SKERENCAK-FRECH, A.; GAST, M.; PANAK, P.J. Fulvic acid complexation of Eu(III) and $\mathrm{Cm}$ (III) at elevated temperatures studied by time-resolved laser fluorescence spectroscopy. Dalton Transactions, v. 43, p. 15593-15601, 2014.

FU, H.; QUAN, X. Complexes of fulvic acid on the surface of hematite, goethite, and akaganeite: FTIR observation. Chemosphere, v. 63, p. 403-410, 2006.

GALVES, M.V.; LOMBARDI, K.C. Caracterização de humina de floresta ombrófila mista, plantio de Araucaria angustifólia e Pinus elliottii na floresta nacional de Irati, PR. In: ENCONTRO ANUAL DE INICIAÇÃO CIENTÍFICA, 19. , 2010, Guarapuava. Anais... Guarapuava: Unicentro, 2010. Disponível em <anais.unicentro.br/xixeaic/pdf/2680.pdf>. Acesso em: 29 ago. 2017.

GHAFFAR, S.H.; FAN, M. Lignin in straw and its applications as an adhesive. International Journal of Adhesion and Adhesives, v. 48, p. 92-101, 2014.

GIOVANELA, M.; CRESPO, J.S.; ANTUNES, M.; ADAMATTI, D.S.; FERNANDES, A.N.; BARISON, A.; DILVA, C.W. P.; GUÉGAN, R.; MOTELICA-HEINO, M.; SIERRA, M.M.D. Chemical and spectroscopic characterization of humic acids extracted from the bottom sediments of a Brazilian subtropical microbasin. Journal of Molecular Structure, v. 981, p. 111-119, 2010. 
GONZÁLEZ PÉREZ, M.; MARTIN-NETO, L.; SAAB, S.C.; NOVOTNY, E.H.; MILORI, D.M.B.P.; BAGNATO, V.S.; COLNAGO, L. A.; MELO, W.J.; KNICKER, H.

Characterization of humic acids from a Brazilian Oxisol under different tillage systems by EPR, 13C NMR, FTIR and fluorescence spectroscopy. Geoderma, v. 118, p. 181-190, 2004.

GONZÁLEZ-PÉREZ, M.; MILORI, D.M.B.P.; COLNAGO, L.A.; MARTIN-NETO, L.; MELO, W.J.A. Laser-induced fluorescence spectroscopic study of organic matter in a Brazilian Oxisol under different tillage systems. Geoderma, v. 138, p. 20-24, 2007.

GRASSET, L.; AMBLÈS, A. Structure of humin and humic acid from an acid soil as revealed by phase transfer catalyzed hydrolysis. Organic Geochemistry, v. 29, p. 881-891, 1998.

GUIMARÃES, F.S. Ecologia e dinâmica vegetal quaternária no contato entre campinarana e campina sobre espodossolos - bacia do Rio Demini- AM. 2014. 143 f. Dissertação (Mestrado em Geografia) - Pós-Graduação em Geografia, Pontíficia Universidade Católica de Minas Gerais, Belo Horizonte, 2014.

GUO, X.J.; ZHU, N.; CHEN, L. Characterizing the fluorescent properties and copper complexation of dissolved organic matter in saline-alkali soils using fluorescence excitationemission matrix and parallel fact. Journal Soils Sediments, v. 15, p. 1473-1482, 2015.

HAHN, D.W.; OMENETTO, N. Laser-Induced Breakdown Spectroscopy (LIBS), part I: review of basic diagnostics and plasma-particle interactions: still-challenging issues within the analytical plasma community. Apply Spectroscopy, v. 64, p. 335-366, 2010.

HARMON, R.S.; RUSSO, R.E.; HARK, R.R. Applications of laser-induced breakdown spectroscopy for geochemical and environmental analysis: A comprehensive review.

Spectrochimica Acta - Part B Atomic Spectroscopy, v. 87, p. 11-26, 2013.

HATCHER, P.G.; MACIEL, G.E.; DENNIS, L.W. Aliphatic structure of humic acids; a clue to their origin. Organic Geochemistry, v. 3, p. 43-48, 1981.

HAVERS, N.; BURBA, P.; LAMBERT, J.; KLOCKOW, D. Spectroscopic characterization of humic-like substances in airborne particulate matter. Journal of Atmospheric Chemistry, v. 29, p. 45-54, 1998.

HAYES, M.H.B. Extraction of Humic Substances from soil. In: AIKEN, G.R.; MCKNIGHT, D. M.; WERSHAW, R.L.; MACCARTHY, P. (Ed.). Humic substances in soil, sediment, and water. New York: John Wiley, 1985. 329 p.

HEDGES, J.; ERTEL, J.R. The lignin component of humic substances: Distribution among soil and sedimentary humic, fulvic, and base-insoluble fractions. Geochimica et Cosmochimica Acta, v. 48, p. 2065-2074, 1984.

HESSE, P.R. A Textbook of soil chemical analysis. New York: Chemical Publishing, 1972. $520 \mathrm{p}$.

INSTITUTO BRASILEIRO DE GEOGRAFIA E ESTATÍSTICA (IBGE). Manual técnico da vegetação brasileira. Rio de Janeiro, 2012. 271 p.

ISHIDA, D. Caracterização e Gênese de Solos e de Depósito de Caulim Associado, São Gabriel da Cachoeira - AM. 2010. 192 f. Tese (Doutorado em Geoquímica de Processos) Instituto de Geociências, Universidade de São Paulo, São Paulo, 2010.

JACOMINE, P.K.T.; CAMARGO, M.N. Classificação pedológica nacional em vigor. In: ALVAREZ, V.H.; FONTES, L.E.F.; FONTES, M.P.F. (Ed.). Solos nos grandes domínios morfoclimáticos do Brasil e o desenvolvimento sustentado. Rio de Janeiro: Embrapa, 1996. p. 675-689. 
JAIN, A.; MOHAPATRA, M.; GODBOLE, S.V.; TOMAR, B.S. Time resolved fluorescence spectroscopy of Eu(III) complexation with alfa-hydroxy isobutyric acid. Spectrochimica Acta Part A: Molecular and Biomolecular Spectroscopy, v. 71, p. 1007-1010, 2008.

JENNY, H. Factors of soil formation: a system of quantitative pedology. Chicago: Courier Corporation, 1994. $281 \mathrm{p}$.

JEX, C.N.; PATE, G.H.; BLYTH, A.J.; SPENCER, R.G.M.; HERNES, P.J.; KHAN, S.J.; BAKER, A. Lignin biogeochemistry: From modern processes to Quaternary archives.

Quaternary Science Reviews, v. 87, p. 46-59, 2014.

JOURAIPHY, A.; AMIR, S.; WINTERTON, P.; EL GHAROUS, M.; REVEL, J.C.; HAFIDI, M. Structural study of the fulvic fraction during composting of activated sludge-plant matter: elemental analysis, FTIR and 13C NMR. Bioresource Technology, v. 99, p. 1066-1072, 2008.

KALBITZ, K.; GEYER, W.; GEYER, S. Spectroscopic properties of dissolved humic substances - a reflection of land use history in a fen area. Biogeochemistry, v. 47, p. 219238, 1999.

KHESHGI, H. S.; JAIN, A. K. Projecting future climate change: implications of carbon cycle model Intercomparisons. Global Biogeochem. Cycles, v. 17, p. 1047, 2003.

KLEBER, M.; JOHNSON, M.G. Advances in understanding the molecular structure of soil organic matter: implications for interactions in the environment. Amsterdam: Elsevier, 2010. v. 106, p. 77-142

KÖGEL-KNABNER, I. 13C and 15N NMR spectroscopy as a tool in soil organic matter studies. Geoderma, v. 80, p. 243-270, 1997.

KONONOVA, M. M. Soil organic matter: its nature role in soil formation and in soil fertility. New York: Pergamon Press, 1966. 544 p.

KUMKE, M.U.; TISEANU, C.; BRAUN, A.G.; FRIMMEL, F.H. Fluorescence decay of natural organic matter (NOM) e influence of fractionation, oxidation, and metal ion complexation. Journal of Fluorescence, v. 8, p. 309-318, 1998.

LAKOWICZ, J.R. Principles of fluorescence espectroscopy. 2. ed. New York: Kluwer Academic/ Plenum Publisher, 1999. 954 p.

LANDGRAF, M.D.; ALVES, M.R.; SILVA, S.C.; REZENDE, M.O.O. Caracterização de Ácidos Húmicos de Vermicomposto de esterco bovino compostado durante 3 e 6 meses. Química Nova, v. 22, p. 483-486, 1999.

LEHMANN, J.; KLEBER, M. The contentious nature of soil organic matter. Nature, v. 528, p. 60-8, 2015.

LI, X.; DAI, X.; TAKAHASHI, J.; LI, N.; JIN, J.; DAI, L.; DONG, B. New insight into chemical changes of dissolved organic matter during anaerobic digestion of dewatered sewage sludge using EEM-PARAFAC and two-dimensional FTIR correlation spectroscopy.

Bioresource Technology, v. 159, p. 412-420, 2014.

LICHTENTHALER, H.; WENZEL, O.; BUSCHMANN, C.; GITTELSON A. Plant stress detection by reflectance and fluorescence. Annals of the New York Academy of Sciences, v. 851, p. 271-285, 1999. 
LOMBARDI, K.C.; MANGRICH, A.S.; WYPYCH, F.; RODRIGUES-FILHO, U.P.; GUIMARÃES, J.L.; SCHREINER, W.H. Sequestered carbon on clay mineral probed by electron paramagnetic resonance and X-ray photoelectron spectroscopy. Journal Colloid Interface Science, v. 295, p. 135-140, 2006.

LUCAS, Y. Systèmes pédologiques en Amazonie brésilienne. Equilibres, déséquilibres et transformations. 1989. 182 f. Thèse (Doctorat em Geochimie de la Surface) - Université de Poitiers, 1989.

LUCAS, Y.; AMBROSI, J.P.; DESJARDINS. T. Transfer of dissolved Al, Fe and Si in two Amazonian forest environments in Brazil. European Journal of Soil Science, v. 49, n. 3, p. 377-384, 1998.

LUCAS, Y.; BOULET, R.; CHAUVEL, A. Intervention simultanée des phénomènes d'enfoncement vertical et de transformation latérale dans la mise en place des systèmes de sols de la zone tropicale humide. Cas des systèmes sols ferrallitiques-podzols de l'Amazonie Brésilienne. C. R. Academie des Sciences de Paris, v. 306, p. 1395-1400, 1988.

LUCAS, Y.; MONTES, C.R.; MOUNIER, S.; CAZALET, M.L.; ISHIDA, D.; ACHARD, R.; GARNIER, C.; MELFI, A.J. Biogeochemistry of an Amazonian podzol-ferralsol soil system with white kaolin. Biogeosciences, v. 9, p. 3705-3720, 2012.

LUCIANI X.; MOUNIER, S.; REDON, R.; BOIS, A. A simple correction method of inner filter effects affecting FEEM and its application to the PARAFAC decomposition. Chemometrics and Intelligent Laboratory Systems, v. 96, n. 2, p. 227-238, 2009.

LUKMAN, S.; SAITO, T.; AOYAGI, N.; KIMURA, T.; NAGASAKI, S. Speciation of Eu3+ bound to humic substances by time-resolved laser fluorescence spectroscopy (TRLFS) and parallel factor analysis (PARAFAC). Geochimica et Cosmochimica Acta, v. 88, p. 199-215, 2012.

LUMB, M.D. Luminescence spectroscopy. London: Academic Press, 1978. 70 p.

LUNDSTROM, U.S. The role of organic acids in the soil solution chemistry of a podzolized soil. European Journal of Soil Science, v. 44, p. 121-133, 1993.

LUSTER, J.; LLOYD, T.; SPOSITO, G. Multi-wavelength molecular fluorescence spectrometry for quantitative characterization of copper(II) and aluminum(III) complexation by dissolved organic matter. Environmental Science Technology, v. 30, p. 1565-1574, 1996.

MANCIULEA, A.; BAKER,A.; LEAD, J.R. A fluorescence quenching study of the interaction of Suwannee River fulvic acid with iron oxide nanoparticles. Chemosphere, v. 76, p. 1023-1027, 2009.

MARTINS, T.; SAAB, S.C.; MILORI, D.M.B.P.; BRINATTI, A.M.; ROSA, J.A.; CASSARO, F.A.M.; PIRES, L.F. Soil organic matter humification under diferente tillage managements evaluated by Laser Induced Fluorescence (LIF) and C/N ratio. Soil Tillage Research, v. 111, p. 231-235, 2011.

MATTHEWS, B.J.H.; JONES, A.C.; THEODOROU, N.K.; TUDHOPE, A.W. Excitationemission-matrix fluorescence spectroscopy applied to humic acid bands in podzolized soil.

Journal Soil Science, v. 44, p. 121-133, 1996.

MCKNIGHT, D.; THURMAN, E.M.; WERSHAW, R.L.; HEMOND, H. Biogeochemistry of aquatic humic substances in thoreau's bog, Concord, Massachusetts. Ecology, v. 66, p. 1339$1352,1985$. 
MILLAR, D.P. Time-resolved fluorescence spectroscopy. Current Opinion in Structural Biology, v. 6, p. 637-642, 1996.

MILLER, J.C.; MILLER, J.N. Statistics for analytical chemistry. 6. ed. Gosport: Ashford Colour Press, 2010. 238 p.

MILORI, D.M.B.P.; GALETI, H.V.A.; MARTIN-NETO, L.; DIECKOW, J.; GONZÁLEZPÉREZ, M.; BAYER, C.; SALTON, J. Organic matter study of whole soil samples using laser-induced fluorescense spectroscopy. Soil Science Society of America Journal, v. 70, p. 57-63, 2006.

MILORI, D.M.B.P.; MARTIN-NETO, L.; BAYER, C.; MIELNICZUK, J.; BAGNATO, V.S. Humification degree of soil humic acids determined by fluorescence spectroscopy. Soil Science, v. 167, p. 739-749, 2002.

MILORI, D.M.B.P.; SEGNINI, A.; SILVA, W.T.L.; POSADAS, A.; MARES, V.; QUIROZ, R.; MARTIN-NETO, L. Emerging techniques for soil carbon measurements.

Copenhagem: CCAFS, 2011. (CCAFS Wnking Paper, 2). Disponível em: < https://ccafs.cgiar.org/publications/emerging-techniques-soil-carbonmeasurements\#.WaXgFNFJnIU> Acesso em: 29 ago. 2017.

MONTES, C.R.; LUCAS, Y.; MELFI, A.; ISHIDA, D. Systèmes sols ferrallitiques-podzols et genèse des kaolins. Geosciences, v. 339, n. 1, p. 50-56, 2007.

MONTES, C.R.; LUCAS, Y.; PEREIRA, O.J.R; ACHARD, R.; GRIMALDI, M.; MELFI, A.J. Deep plant-derived carbon storage in Amazonian podzols. Biogeosciences, v. 8, p. 113$120,2011$.

MOUNIER, S.; BRAUNCHER, R.; BENAIM, J.Y. Differentiation of organic matter`s properties of the Rio Negro basin by cross-flow ultrafiltration and UV-spectrofluorescence. Water Research, v. 33, p. 2363-2373, 1999.

MOUNIER, S.; PATEL, N.; QUILICI, L.; BENAIM, J. Y.; BENAMOU, C. Fluorescence 3D de la matière organique dissoute du fleuve amazone : (three-dimensional fluorescence of the dissolved organic carbon in the Amazon river). Water Research, v. 33, n. 6, p. 1523-1533, 1999.

MOUNIER, S.; ZHAO, H.; GARNIER, C.; REDON, R. Copper complexing properties of dissolved organic matter: PARAFAC treatment of fluorescence quenching. Biogeochemistry, v. 106, p. 107-116, 2011.

MUNSELL. Munsell soil color charts. New York: Munsell Color/GretagMacBeth, 2000. P. 30

NAM, K.; KIM, J.Y. Role of loosely bound humic substances and humin in the bioavailability of phenanthrene aged in soil. Environmental Pollution, v. 118, n. 3, p. $427-$ 433, 2002.

NASCIMENTO, N.R.; BUENO, G.T.; FRITSCH, E.; HERBILLON, A.J.; ALLARD, T.; MELFI, A.J.; ASTOLFO, R.; BOUCHER, H.; LI, Y. Podzolization as a deferralitization process: a study of an Acrisol-Podzol sequence derived from Palaeozoic sandstones in the northern upper Amazon Basin. European Journal of Soil Science, v. 55, n. 3, p. 523-538, 2004.

NASCIMENTO, N.R.; FRITSCH, E.; BUENO, G.T.; BARDY, M.; GRIMALDI, C.; MELFI, A.J. Podzolization as a deferralitisation process: dynamics and chemistry of ground and surface waters in an Acrisol-Podzol sequence of the upper Amazon Basin. European Journal of Soil Science, v. 59, p. 911-924, 2008. 
NEARPASS, D.C. Adsorption of picloramby humic acids and humin. Soil Science, v. 121, p. 272-277, 1976.

NEILL, C.; COE, M.T.; RISKIN, S.H.; KRUSCHE, A.V.; ELSENBEER, H.; MACEDO, M.N.; MCHORNEY, R.; LEFEBVRE, P.; DAVIDSON, E.A.; SCHEFFLER, R.; FIGUEIRA, A.M.S.; PORDER, S.; DEEGAN, L.A. Watershed responses to Amazon soya bean cropland expansion and intensification. Philosophical Transactions of the Royal Society B, v. 368, p. 04-25, 2013.

NICHOLS, K.A.;WRIGHT, S.F. Carbon and nitrogen in operationally defined soil organic matter pools. Bioliogy Fertility of Soils, v. 43, p. 215-220, 2006.

NICOLODELLI, G.; COE, M.T.; RISKIN, S.H.; KRUSCHE, A.V.; ELSENBEER, H.; MACEDO, M.N.; MCHORNEY, R.; LEFEBVRE, P.; DAVIDSON, E.A.; SCHEFFLER, R.; FIGUEIRA, A.M.S.; PORDER, S.; DEEGAN, L.A. Quantification of total carbon in soil using laser- induced breakdown spectroscopy: amethod to correct interference lines. Apply Optics, v. 53, p. 2170-2176, 2014.

NICOLODELLI, G.; TADINI, A.M.; NOGUEIRA, M.S.; PRATAVIEIRA, S.; MOUNIER, S.; HUAMAN, J.L.C.; SANTOS, C.H.; MONTES, C.R.; MILORI, D.M.B.P. Fluorescence lifetime evaluation of whole soils from the Amazon rainforest. Applied Optics, v. 56, 24, p. 6936-6941, 2017.

OLIVEIRA, A.A.; DALY, D.C. VICENTINI, A.; COHN-HAFT, M. Florestas sobre areia: campinaranas e igapós. In: OLIVEIRA, A.A.; DALY, D.C. Florestas do Rio Negro. São Paulo: UNIP, 2001, v. 1, p. 1-42.

OLIVEIRA, J.B. Pedologia aplicada. 4. ed. Piracicaba: Fealq, 2011. 592 p.

PAN, B.; XING, B.S.; LIU, W.X.; TAO, S.; LIN, X.M.; ZHANG, X.M.; ZHANG, Y.X.; XIAO, Y.; DAI, H.C.; YUAN. H.S. Distribution of sorbed phenanthrene and pyrene in different humic fractions of soils and importance of humin. Environmental Pollution, v. 143, n. 1, p. 24-33, 2006.

PATEL-SORRENTINO, N.; LUCAS, Y.; EYROLLE, F.; MELFI, A. J. Fe, Al and Si species and organic matter leached off a ferrallitic and podzolic soil system from Central Amazonia. Geoderma, v. 137, p. 444-454, 2007.

PAUL, E.A. The nature and dynamics of soil organic matter: Plant inputs, microbial transformations, and organic matter stabilization. Soil Biology and Biochemistry, v. 98, p. 109-126, 2016.

PÉDROT, M.; DIA, A.; DAVRANCHE, M. Dynamic structure of humic substances: rare earth elements as a fingerprint. Journal of Colloid and Interface Science, v. 345, p. 206$213,2010$.

PEREIRA, O.J.R.; MONTE, C.R.; LUCAS, Y.; MELFI, A.J. A multisensor approach for mapping plant-derived carbon storage in Amazonian podzols. International Journal of Remote Sensing, v. 36, n. 8, p. 2076-2092, 2015.

PEREIRA, O.J.R.; MONTE, C.R.; LUCAS, Y.; MELFI, A.J. Use of remote sense imagery for mapping deep plant-derived carbon storeage in Amazonian podzols in regional scale. In: IEEE INTERNATIONAL SYMPOSUM ON GEOSCIENCE AND REMOTE SENSING, 3770, 2013, Melbourne. Abstract... Melbourne: IEEE, 2013. Disponível em: < http://ieeexplore.ieee.org/document/6723651/>. Acesso em: 29 ago. 2017. 
PEURAVUORI, J.; KOIVIKKO, R.; PIHLAJA, K. Characterization, differentiation and classification of aquatic humic matter separated with different sorbents: synchronous scanning fluorescence spectroscopy. Water Research, v. 36, p. 4552-4562, 2002.

PEURAVUORI, J.; PIHLAJA, K. Molecular size distribution and spectroscopic properties of aquatic humic substances. Analytica Chimica Acta, v. 337, n. 2, p. 133-149, 1997.

PICCOLO, A. Humus and Soil Conservation. In: HUMIC substances in terrestrial ecosystems. Amsterdam: Elsevier, 1996. p. 225-264.

PICCOLO, A. In memoriam Prof. F.J. Stevenson and the question of humic substances in soil. Chemical Biological Technologies in Agriculture, v. 3, p. 23, 2016.

PICCOLO, A. The supramolecular structure of humic substances. Soil Science, v. 166, p. 810-832, 2001.

PICCOLO, A.; CONTE, P.; TRIVELLONE; E.; VAN LAGEN, B. Reduced heterogeneity of a lignite humic acid by preparative HPSEC following interaction with an organic acid.

Characterization of size-separates by Pyr-GC-MS and ${ }^{1} \mathrm{H}-\mathrm{NMR}$ spectroscopy.

Environmental Science Technology, v. 36, p. 76-84, 2002.

PRENDERGAST, F.G. Time-resolved fluorescence techniques: methods and applications in biology. Current Opinion in Structural Biology, v. 1, p. 1054-1059, 1991.

RESENDE, M.; CURI, N.; REZENDE, S. B.; CORRÊA, G.F. Pedologia: base para distinção de ambientes. 5. ed. Lavras: Editora UFLA, 2009. 321p.

RIBEIRO, A. M. B. Indicadores químicos e microbiológicos de qualidade do solo em ambientes naturais e antropizados do Complexo Vegetacional de Campo Maior-PI. 2007. 51f. Dissertação (Mestrado em Desenvolvimento e Meio Ambiente) - Programa de PósGraduação em Desenvolvimento e Meio Ambiente/UFPI, Teresina, 2007.

RICE, J.; MACCARTHY, P. Isolation of humin by liquid-liquid partitioning. Science Total Environmental, v. 81/82, p. 61-69, 1989.

RICE, J.A. Humin. Soil Science, v. 166, p. 848-857, 2001.

ROCHA, J.C.; ROSA, A.H. Substâncias húmicas aquáticas: interações com espécies metálicas. São Paulo: Ed. UNESP, 2003. p. 200

ROCHA, J.C.; ROSA, A.H.; CARDOSO, A.A. Introdução a química ambiental. Porto Alegre: Ed. Bookman, 2004. p.155

RODRÍGUEZ, F.J.; NÚÑEZ, L.A. Characterization of aquatic humic substances. Water and Environment Journal, v. 25, p. 25163-170, 2011.

RODRÍGUEZ-ZÚÑIGA, U.F.; MILORI, D.M.B.P.; DA SILVA, W.T.L.; MARTIN-NETO, L.; OLIVEIRA, L.C.; ROCHA, J.C. Changes in optical properties caused by UV-irradiation of aquatic humic substances from the Amazon River basin: Seasonal variability evaluation.

Environmental Science and Technology, v. 42, p. 1948-1953, 2008.

RUSSEL, J.D.; FRASER, A.R. Infrared methods. In: WILSON, M. J., CHAPMAN, H. Clay mineralogy. London: Chapman and Hall, 1994. 11-44 p.

RYAN, D.K. Liquid chromatography: humic substances. In: ENCYCLOPEDIA of separation science. London: Academic Press, 2000. p. 3033-3039

RYAN, D.K.; WEBER, J.H. Fluorescence quenching titration for determination of complexing capacities and stability constants of fulvic acid. Analytical Chemistry, v. 54, p. 986-990, 1982. 
SAADI, I.; BORISOVER, M.; ARMON, R.; LAOR, Y. Monitoring of effluent DOM biodegradation using fluorescence, UV and DOC measurements. Chemosphere, v. 63, p. 530-539, 2006.

SALVADOR, J.T.; CARVALHO, T.C. Relações cálcio e magnésio presentes no solo e teores foliares de macronutrientes. Revista Acadêmica, Ciência Agrária Ambiental, v. 9, p. 27 32, 2011.

SANTÍN, C.; YAMASHITA, Y.; OTERO, X.L.; ÁLVAREZ, M.Á.; JAFFÉ, R. Characterizing humic substances from estuarine soils and sediments by excitation-emission matrix spectroscopy and parallel factor analysis. Biogeochemistry, v. 96, p. 131-147, 2009.

SANTOS, C.H. Estudo da matéria orgânica e composição elementar de solos arenosos de regiões próximas a São Gabriel da Cachoeira no Amazonas. 2014. 155 f. Tese (Doutorado em Química Analítica) - Instituto de Química de São Carlos, Universidade de São Paulo, São Carlos, 2014.

SANTOS, C.H.; ROMANO, R.A.; NICOLODELLI, G.; CARVALHO, C.M.; VILLASBOAS, P.R.; MARTIN-NETO, L.; MONTES, C.R.; MELFI, A.J.; MILORI, D.M.B.P. Performance Evaluation of a Portable Laser-Induced Fluorescence Spectroscopy System for the Assessment of the Humification Degree of the Soil Organic Matter. Journal of Brazilian Chemical Society, v. 26, p. 775-783, 2015.

SANTOS, R.D.; LEMOS, R.C.; SANTOS, H.G.; KER, J.C.; ANJOS, L.H.C. Manual de descrição e coleta de solo no campo. Viçosa: Sociedade Brasileira de Ciência do Solo, 2005. P. 100.

SARGENTINI JUNIOR, E.; ROCHA, J.C.; ROSA, A.H.; ZARA, L.F.; DOS SANTOS, A. Substâncias húmicas aquáticas: fracionamento molecular e caracterização de rearranjos internos após complexação com íons metálicos. Química Nova, v. 24, p. 339-344, 2001.

SCHIAVO, J.A.; CANELLAS, L.P.; MARTINS, M.A. Extração de cava de extração de argila com Acacia mangium. I - atributos químicos do solo, ácido fúlvico e húmico. Revista

Brasileira de Ciência do Solo, v. 31, n. 5, p. 1153-1162, 2007.

SCHMIDT, M.W.I.; TORN, M.S.; ABIVEN, S.; DITTMAR, T.; GUGGENBERGER, G.; JANSSENS, I. A.; KLEBER, M.; KÖGEL-KNABNER, I.; LEHMANN, J.; MANNING, D.A.C.; NANNIPIERI, P.; RASSE, D.P.; WEINER, S.; TRUMBORE, S.E. Persistence of soil organic matter as an ecosystem property. Nature, v. 478, p. 49-56, 2011.

SCHULTEN, H.R.; SCHNITZER, M. A state of the art structural concept for humic substances. Naturwissenschaften, v. 80, p. 29-30, 1993.

SCHULTEN, H.R.; SCHNITZER, M. Chemical model structures for soil organic matter and soils. Soil Science, v. 162, p. 115-130, 1997.

SEGNINI, A.; DE SOUZA, A.A.; NOVOTNY, E.H.; MILORI, D.M.B.P.; DA SILVA, W.T.L.; BONAGAMBA, T.J.; POSADAS, A.; QUIROZ, R. Characterization of peatland soils from the high andes through c nuclear magnetic resonance spectroscopy. Soil Science Society of America Journal, v. 77, p. 673, 2013.

SENESI, G.S.; MARTIN-NETO, L.; VILLAS-BOAS, P.R.; NICOLODELLI, G. MILORI, D.M.B.P. Laser-based spectroscopic methods to evaluate the humification degree of soil organic matter in whole soils: a review. Journal of Soils and Sediments, p. 1-11, 2016.

SENESI, G.S.; SENESI, N. Laser-induced breakdown spectroscopy (LIBS) to measure quantitatively soil carbon with emphasis on soil organic carbon. A review. Analytica Chimica Acta, v. 938, p. 7-17, 2016. 
SENESI, N.; LOFFREDO, E. The Chemistry of soil organic matter. Soil Physical Chemistry, v. 2, p. 239-370, 2013.

SENESI, N.; MIANO, T. M.; PROVENZANO, M. R.; BRUNETTI, G. Spectroscopic and Compositional Comparative Characterization of I.H.S.S. Reference and Standard Fulvic and Humic Acids of Various Origin. The Science of the Total Environment, v. 81/82, p. 143-56, 1989.

SENESI, N.; MIANO, T.M.; PROVEZANO, M.R.; BRUNETTI, G. Characterization, differentiation, and classification of humic substances by fluorescence spectroscopy. Soil Science, v. 152, p. 259-271, 1991.

SIERRA, M.M.D.; GIOVANELA, M.; PARLANTI, E.; SORIANO-SIERRA, E.J. Fluorescence fingerprint of fulvic and humic acids from varied origins as viewed by singlescan and excitation/emission matrix techniques. Chemosphere, v. 58, p. 715-733, 2005.

SILVERSTEIN, R.M.; BASSLER, G.; MORRIL, T.C. Identificação espectrométrica de compostos orgânicos. Rio de Janeiro, Guanabara-Koogan, 1994. p. 387.

SIMPSON, A.J.; SIMPSON, M.J. Nuclear magnetic resonance analysis of natural organic matter. In: SENESI, N.; XING, N.; HUANG, P.M. (Ed). Biophysico-chemical processes involving natural organic matter in environmental systems. Hoboken: Wiley, 2009. p. $589-650$

SKOOG, D.A. Analytical chemistry. 6. ed. Cole: Brooks, 2005. 1000 p.

SLOBODA, E. Influência do tamanho molecular aparente das substâncias húmicas aquáticas na eficiência da coagulação com sulfato de alumínio e cloreto férrico. 2007. 108 f. Dissertação (Mestrado em Hidraulica e Saneamento) - Escola de Engenharia de São Carlos, Unversidade de São Paulo, São Carlos, 2007.

SLOBODA, E.; VIEIRA, E. M.; DANTAS, A.D.B.; BERANDO, L.D. Influência das características das substâncias húmicas aquáticas na eficiência da coagulação com o cloreto férrico. Química Nova, v.32, n. 4, p. 976-982, 2009.

SMIDT, H.; DE VOS, W.M. Anaerobic microbial dehalogenation. Annual Review of Microbiology, v. 58, p. 43-73, 2004.

SMITH, D.S.; KRAMER, J.R. Multisite metal binding to fulvic acid determined using multiresponse fluorescence. Analytical Chemical Acta, v. 416, p. 211-220, 2000.

SONG, G.; NOVOTNY, E.H.; SIMPSON, A.J.; CLAPP, C.E.; HAYES, M.H.B. Sequential exhaustive extraction of a Mollisol soil, and characterizations of humic components, including humin, by solid and solution state NMR. European Journal of Soil Science, v. 59, p. 505$516,2008$.

SOUSA, R.; CAMARGO, F.A.O.; VAHL, L.C. Solos alagados: reações de redox. In: MEURER, E.J. (Ed.). Fundamentos de química do solo. Porto ALegre: Evangraf, 2010. p. 171-195.

SPACCINI, R.; PICCOLO, A. Molecular characteristics of humic acids extracted from compost at increasing maturity stages. Soil Biology \& Biochemistry, v. 41, p. 1164-1172, 2009 .

STEDMON, C.A.; MARKAGER, S.; BRO, R. Tracing dissolved organic matter in aquatic environments using a new approach to fluorescence spectroscopy. Marine Chemistry, v. 82, p. $239-254,2003$. 
STEVENSON, F.J. Cicles of soil: carbon, nitrogen, phosphorus, sulfur, micronutrients. New York: John Wiley, 1986. p. 380

STEVENSON, F.J. Humus chemistry: genesis, composition and reaction. 2. ed. New York: John Wiley, 1994. p. 390

STEVENSON, F.J. Humus chemistry: genesis, composition and reaction. New York: John Wiley, 1982. p. 390

SUTTON, R.; SPOSITO, G. Molecular structure in soil humic substances: The new view. Environmental Science and Technology, v. 39, p. 9009-9015, 2005.

SWIFT, R.S. Organic matter characterization. In: SPARKS, D.L; PAGE, A.L.; HELMKE, P.A.; LOEPPERT, R.H.; SOLTANPOUR, P.N.; TABATABAI, M.A.; JOHNSTON, C.T.; SUMMER, M.E. (Ed). Methods of soil analysis: chemical methods. Madison: Soil Science Society of America, 2009. Cap. 35, p. 1018-1020. (Soil Science Society of America book series, v. 5).

TADINI, A.M. Substâncias húmicas aquáticas : caracterização e interação com íons crômio e proposta de um indicador de matéria orgânica lábil. 2013. 128 f. Dissertação (Mestrado em Química Analítica) - Departamento de Química e Ciências Ambientais, Universidade Estadual Paulista, "Júlio de Mesquita Filho", São José do Rio Preto, 2013.

TADINI, A.M.; HAJJOUL, H.; NICOLODELLI, G.; MOUNIER, S.; MONTES, C.R.; MILORI, D.M.B.P. Characterization of Organic Matter in Spodosol Amazonian by Fluorescence Spectroscopy. World Academy of Science, Engineering and Technology, v. 11, p. 352-355, 2017.

TADINI, A.M.; NICOLODELLI, G.; MOUNIER, S.; MONTES, C.R.; MILORI, D.M.B.P. The importance of humin in soil characterisation: A study on Amazonian soils using different fluorescence techniques. Science of the Total Environment, v. 537, p. 152-158, 2015.

TADINI, A.M.; PANTANO, G.; DE TOFFOLI, A.L.; FONTAINE, B.; SPACCINI, R.; PICCOLO, A.; MOREIRA, A.B.; BISINOTI, M.C. Off-line TMAH-GC/MS and NMR characterization of humic substances extracted from river sediments of northwestern São Paulo under different soil uses. Science of the Total Environment, v. 506-507, p. 234-240, 2015.

TIVET, F.; SÁ, M.J.C.; LAL, R.; MILORI, D.M.B.P.; BRIEDIS, C.; LETOURMY, P.; PINHEIRO, L. A.; BORSZOWSKEI, P.R.; HARTMAN, D.C. Assessing humification and organic $\mathrm{C}$ compounds by laser-induced flurescence and FTIR spectroscopies under conventional and no-till management in Brazilian Oxisols. Geoderma, v. 207/208, p. 71-81, 2013.

TRUMBORE, S.; CAMARGO, P.B. Dinâmica do carbono do solo. Amazonia and Global Change, p. 451-462, 2009.

VALE JÚNIOR, J.F.; SUZA, M.I.L.; NASCIMENTO, P.P.R.R.; CRUZ, D.L.S. Soils of the Amazon: etnopedology and sustainable development. Centro de Ciências Agrárias -

Universidade Federal de Roraima, Boa Vista. Revista Agroambiente On-line, v. 5, n. 2, p. 158-165, 2011.

VALENCIA, S.; MARÍN, J.M.; RESTREPO, G.; FRIMMEL, F.H. Application of excitationemission fluorescence matrices and UV/Vis absorption to monitoring the photocatalytic degradation of commercial humic acid. Science of the Total Environment, v. 442, p. 207$214,2013$. 
VANLOON, G.W.; DUFFY, S.J. Environmental chemistry a global perspective. Oxford: University Press, 2000. p. 560

VAZ, S.; LOPES, W.T.; MARTIN-NETO, L. Study of molecular interactions between humic acid from Brazilian soil and the antibiotic oxytetracycline. Environmental Technology and Innovation, v. 4, p. 260-267, 2015.

VOLIKOV, A.B.; KHOLODOV, V.A.; KULIKOVA, N.A.; PHILIPPOVA, O.I.; PONOMARENKO, S.A.; LASAREVA, E.V.; PARFYONOVA, A.M.; HATFIELD, K.; PERMINOVA, I.V. Silanized humic substances act as hydrophobic modifiers of soil separates inducing formation of water-stable aggregates in soils. Catena, v. 137, p. 229-236, 2016.

VON LUTZOW, M.; KOGEL-KNABNER, I.; EKSCHMITT, K.; MATZNER, E.; GUGGENBERGER, G.; MARSCHNER, B.; FLESSA, H. Stabilization of organic matter in temperate soils: mechanisms and their relevance under different soil conditions: a review.

European Journal of Soil Science, v. 57, n. 4, p. 426-445, 2006.

WEI, Z.; ZHAO, X.; ZHU, C.; XI, B.; ZHAO, Y.; YU, X. Assessment of humification degree of dissolved organic matter from different composts using fluorescence spectroscopy technology. Chemosphere, v. 95, p. 261-267, 2014.

WEISHAAR, J.; AIKEN, G.R.; BERGAMASCHI, B.A.; FRAM, M.S.; FUJIL, R.; MOPPER, K. Evaluation of specific ultraviolet absorbance as an indicator of the chemical composition and reactivity of dissolved organic carbon. Environmental Science Technology, v. 37, p. 4702-4708, 2003.

WOLF, J.D. Soil solution chemistry: applications to environmental science and agriculture. New York: John Wiley, 1994. p. 360

WU, F.; BAI, Y.; MU, Y.; PAN, B.; XING, B.; LIN, Y. Fluorescence quenching of fulvic acids by fullerene in water. Environmental Pollution, v. 172, p. 100-107, 2013.

WU, J.; ZHAO, Y.; ZHAO, W.; YANG, T.; ZHANG, X.; XIE, X.; CUI, H.; WEI, Z. Effect of precursors combined with bacteria communities on the formation of humic substances during different materials composting. Bioresources Technology, v. 226, p. 191-199, 2017.

YAMASHITA, Y.; JAFFE, R. Characterizing the interactions between trace metals and dissolved organic matter using excitation-emission matrix and parallel factor analysis. Environmental Science Technology, v. 42, p. 7374-7379, 2008.

YANG, Z.; SINGH, B.R.; SITAULA, B.K. Fractions of organic carbon in soils under different crop rotations, cover crops and fertilization practices. Nutrient Cycling Agroecosystems, v. 70, p. 161-166, 2004.

ZECH, W.; SENESI, N.; GUGGENBERGER, G.; KAISER, K.; LEHMANN, J.; MIANO, T.M.; MILTNER, A.; SCHROTH, G. Factors controlling humification and mineralization of soil organic matter in the tropics. Geoderma, v. 79, p. 117-161, 1997.

ZHANG, Y.; HAN, G.; JIANG, T.; HUANG, Y.; LI, G.; GUO, Y.; YANG, Y. Structure characteristics and adhesive property of humic substances extracted with different methods. Journal Central South University Technology, v. 18, p. 1041-1046, 2011.

ZHU, B.; PENNELL, S. A.; RYAN, D.K. Characterizing the interaction between uranyl ion and soil fulvic acid using parallel factor analysis and a two-site fluorescence quenching model. Microchemical Journal, v. 115, p. 51-57, 2014. 
ZIEGELGRUBER, K.L.; ZENG, T.; ARNOLD, W.A.; CHIN, Y. Sources and composition of sediment pore-water dissolved organic matter in prairie pothole lakes. Limnology and Oceanography, v. 58, p. 1136-1146, 2013.

ZÚÑIGA, U.F.R. Avaliação da influência de fatores ambientais na estrutura, dinâmica, propriedades ópticas das substâncias húmicas aquáticas do rio Negro. 2006. 160 f. Dissertação (Mestrado em Química Analítica) - Instituto de Química de São Carlos, Universidade de São Paulo, São Carlos, 2006. 


\section{Capítulo 8 - Anexos}


ANEXO - A: Rendimento do Carbono

Tabela 5.II.9: Rendimento do Carbono obtido pelo processo de extração dos ácidos húmicos, ácidos fúlvicos e humina dos Espodossolos Amazônico.

\begin{tabular}{c|c|c|c}
\hline Amostras & $\begin{array}{c}\text { Acido Húmico } \\
\text { \% Rendimento* }\end{array}$ & $\begin{array}{c}\text { Acido Fúlvico } \\
\text { \% Rendimento* }\end{array}$ & $\begin{array}{c}\text { Humina } \\
\text { \% Rendimento* }\end{array}$ \\
\hline P1 A 0-15 & 15,84 & 0,50 & 24,21 \\
P1 A 15-30 & 51,02 & 1,68 & 38,92 \\
P1 Bh 40-50 & 38,79 & 0,90 & 15,35 \\
P1 Bh-C 240 & 2,09 & 4,13 & 0,85 \\
P1 Bh-C 260 & 1,52 & 3,42 & 13,57 \\
P1 C 350 & 7,30 & 3,02 & 12,67 \\
\hline P2 A 0-15 & 15,27 & 3,06 & 3,82 \\
P2 A-E 15-30 & 17,58 & 2,71 & 1,99 \\
P2 Bh 290 & 6,01 & 0,20 & 0,10 \\
\hline P3 A 0-15 & 25,07 & 3,63 & 6,48 \\
P3 Bh 165-175 & 20,99 & 3,49 & 0,23 \\
P3 Bh 180-183 & 6,61 & 0,22 & 0,38 \\
P3 Bh 210 & 2,42 & 3,63 & 1,50 \\
P3 Bh 280-310 & 6,91 & 3,49 & 0,25 \\
P3 Bh 335-350 & 12,91 & 0,22 & 0,28 \\
\hline P4 A 0-20 & 5,49 & 0,52 & 1,14 \\
P4 A 20-30 & 18,37 & 1,43 & 6,34 \\
P4 A 30-40 & 3,64 & 0,06 & 5,17 \\
P4 Bh 110-120 & 3,30 & 6,82 & 7,34 \\
P4 Bh 170-180 & 8,63 & 1,12 & 6,63 \\
P4 Bh-C 270-280 & 20,05 & 24,42 & 93,57 \\
P4 Bh 370-380 & 2,47 & 1,24 & 2,10 \\
P4 Bh 380-390 & 2,55 & 4,51 & 1,53 \\
\hline
\end{tabular}

*Cálculo utilizado está representado pela equação abaixo:

$$
\% \text { Rendimento }=\left(\frac{\text { MFração } \mathrm{X} \% \text { CFração }}{\text { MSolo } \mathrm{X} \% \text { CSolo }}\right) \times 100
$$

\% Rendimento: porcentagem do rendimento de carbono obtido pelo processo de extração;

MFração: Massa obtida no final da extração da Fração Ácido Húmico ou Ácido Fúlvico ou Humina;

\%CFração: Porcentagem de Carbono obtido da fração Ácido Húmico ou Ácido Fúlvico ou Humina;

MSolo: Massa utilizada para extração da Fração Ácido Húmico ou Ácido Fúlvico ou Humina;

\%CSolo: Porcentagem de Carbono obtido no solo.

Fonte: Autoria Própria. 


\section{Anexos 2017}

ANEXO - B: Teores de Cinzas

Tabela 5.II.11: Valores obtidos pelo teste de cinza das amostras de ácido húmico, ácido fúlvico e humina extraído dos Espodossolos Amazônico.

\begin{tabular}{|c|c|c|c|c|c|c|}
\hline \multirow[b]{2}{*}{ Amostras } & \multicolumn{2}{|c|}{ HUMINA } & \multicolumn{2}{|c|}{ ÁCIDO HÚMICO } & \multicolumn{2}{|c|}{ ÁCIDO FÚLVICO } \\
\hline & $\%$ Cinzas & $\% \mathrm{MO}$ & $\%$ Cinzas & $\% \mathrm{MO}$ & $\%$ Cinzas & $\% \mathrm{MO}$ \\
\hline P1 A 0-15 & 87,7 & 12,3 & 14,9 & 85,1 & - & - \\
\hline P1 A 15-30 & 98,4 & 1,6 & 3,3 & 96,7 & 84,4 & 15,6 \\
\hline P1 Bh 40-50 & 99,1 & 0,9 & 6,1 & 93,9 & 86,7 & 13,3 \\
\hline P1 Bh-C 240 & 100,0 & 0,0 & 0,0 & 100,0 & 78,9 & 21,1 \\
\hline P1 Bh-C 260 & 96,0 & 4,0 & 7,7 & 92,3 & 82,7 & 17,3 \\
\hline P1 C 350 & 97,1 & 2,9 & 5,2 & 94,8 & 80,6 & 19,4 \\
\hline P2 A 0-15 & 100,0 & 0,0 & 32,4 & 67,6 & 73,8 & 26,2 \\
\hline P2 A-E 15-30 & 98,8 & 1,2 & 26,1 & 73,9 & 82,0 & 18,0 \\
\hline P2 Bh 290 & 100,0 & 0,0 & 4,8 & 95,2 & 76,0 & 24,0 \\
\hline P3 A 0-15 & 100,0 & 0,0 & 1,1 & 98,9 & 87,5 & 12,5 \\
\hline P3 Bh 165-175 & 98,2 & 1,8 & 3,4 & 96,6 & 73,6 & 26,4 \\
\hline P3 Bh 180-183 & 45,9 & 54,1 & 0,0 & 100,0 & 48,0 & 52,0 \\
\hline P3 Bh 210 & 99,5 & 0,5 & 16,9 & 83,1 & 75,5 & 24,5 \\
\hline P3 Bh 280-310 & 97,6 & 2,4 & 1,4 & 98,6 & 75,4 & 24,6 \\
\hline P3 Bh 335-350 & 99,4 & 0,6 & 1,0 & 99,0 & 98,0 & 2,0 \\
\hline P4 A 0-20 & 99,3 & 0,7 & 8,6 & 91,4 & 79,7 & 20,3 \\
\hline P4 A 20-30 & 100,0 & 0,0 & 4,8 & 95,2 & 81,0 & 19,0 \\
\hline P4 A 30-40 & 94,1 & 5,9 & 20,0 & 80,0 & 76,0 & 24,0 \\
\hline P4 Bh 110-120 & 100,0 & 0,0 & 47,4 & 52,6 & 81,4 & 18,6 \\
\hline P4 Bh 170-180 & 98,5 & 1,5 & 4,0 & 96,0 & 80,7 & 19,3 \\
\hline P4 Bh-C 270-280 & 100,0 & 0,0 & 0,0 & 100,0 & 89,5 & 10,5 \\
\hline P4 Bh 370-380 & 96,9 & 3,1 & 6,7 & 93,3 & 87,2 & 12,8 \\
\hline P4 Bh 380-390 & 100,0 & 0,0 & 7,1 & 92,9 & 85,5 & 14,5 \\
\hline
\end{tabular}

Fonte: Autoria Própria. 


\section{Anexos 2017}

ANEXO - C: Espectros de Infravermelho com Transformada de Fourier

Figura 5.II.16: Espectro típico de Infravermelho das amostras (a) Ácido Húmico, (b) Ácido Fúlvico e (c) Humina extraídos do Espodossolo Hidromórfico (P2).
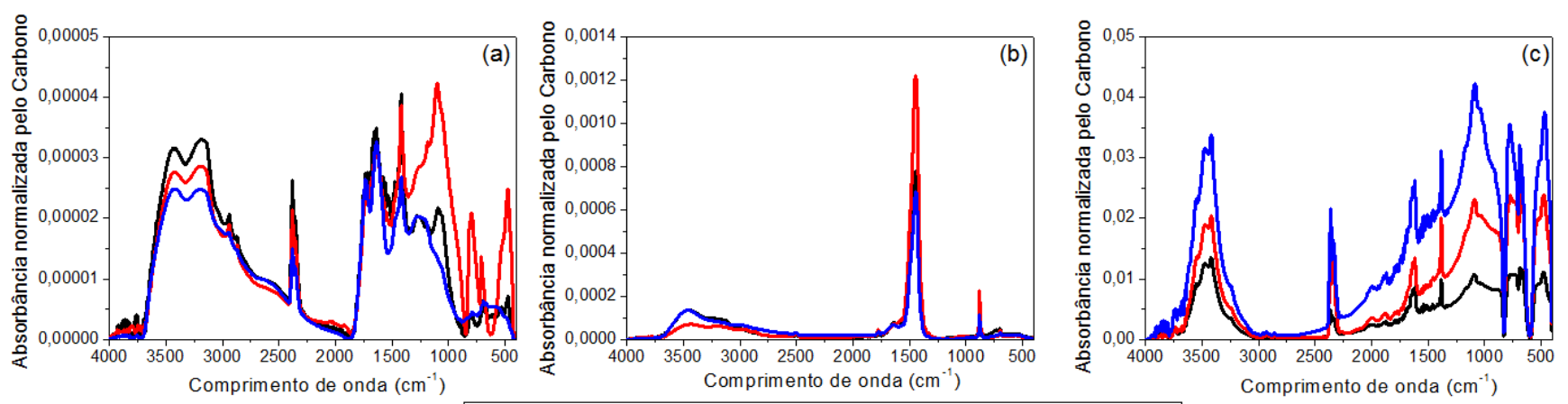

Fonte: Autoria Própria.

Figura 5.II.17: Espectro típico de Infravermelho das amostras (a) Ácido Húmico, (b) Ácido Fúlvico e (c) Humina extraídos do Espodossolo Hidromórfico (P3).
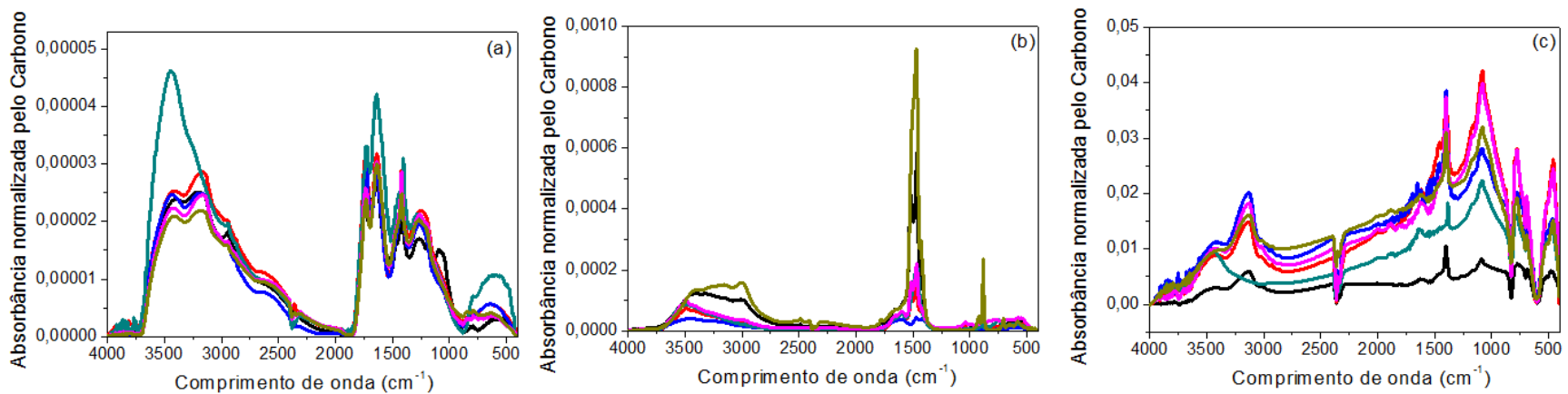

-P3 A 0-15 —P3 Bh 165-175 —P3 Bh 180-183 —P3 Bh 210 —P3 Bh 280-310 —P3 Bh 335-350

Fonte: Autoria Própria.

Figura 5.II.18: Espectro típico de Infravermelho das amostras (a) Ácido Húmico, (b) Ácido Fúlvico e (c) Humina extraídos do Espodossolo Bem Drenado (P4).
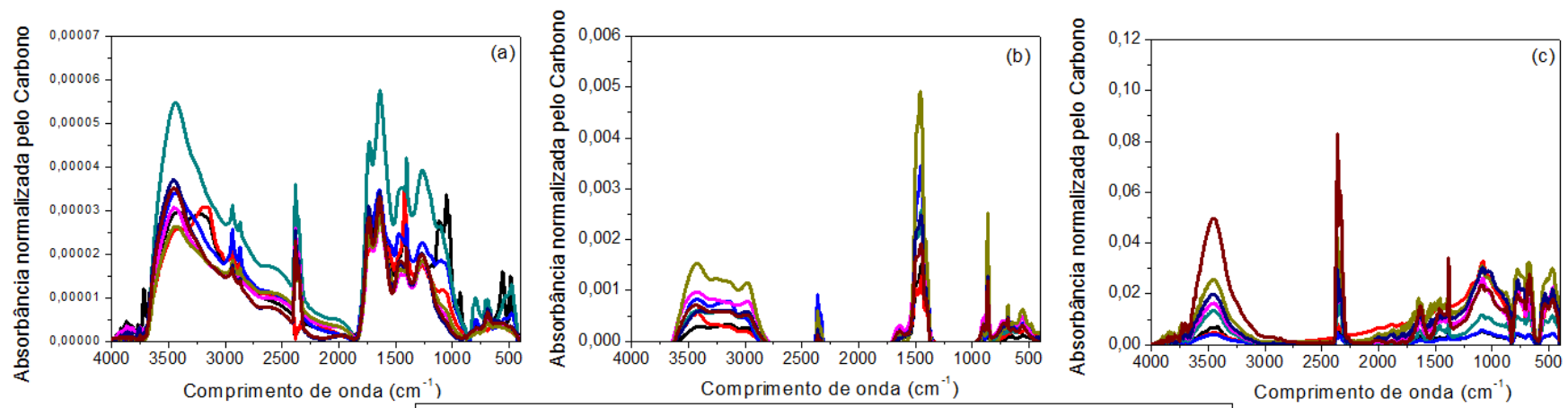

-P4 A 0-20 —P4 A 20-30 —P4 A 30-40 — P4 Bh 110-120 Comprimento de onda $\left(\mathrm{cm}^{-1}\right)$ P4 Bh 170-180 —P4 Bh-C 270-280 —P4 Bh 370-380 —P4 Bh-C 380-390

Fonte: Autoria Própria. 
ANEXO - D: Espectros de fluorescência bidimensional empregando a Espectroscopia de Fluorescência Molecular

Figura 5.II.23: Espectros de Fluorescência bidimensional utilizando a metodologia proposta por Kalbitz et al. (1999) para as amostras de (a) ácido húmico e (b) ácido fúlvico do Espodossolo Hidromórfico (P1).

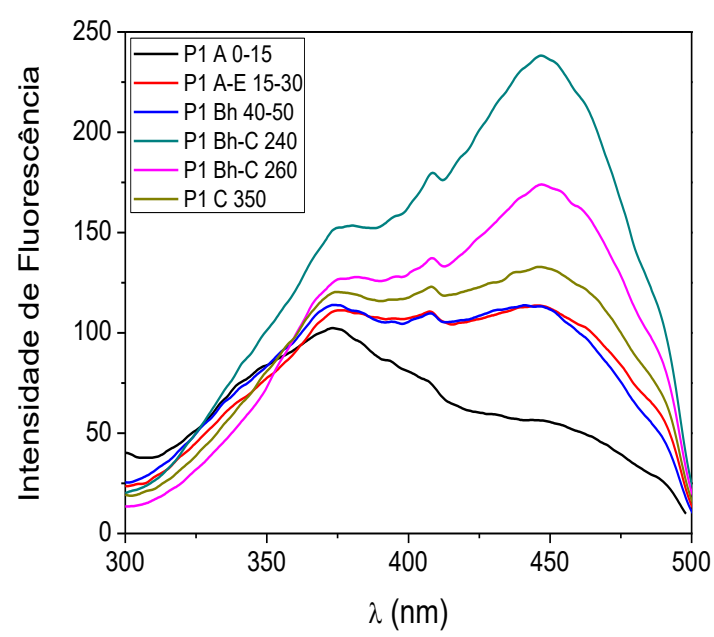

(a)

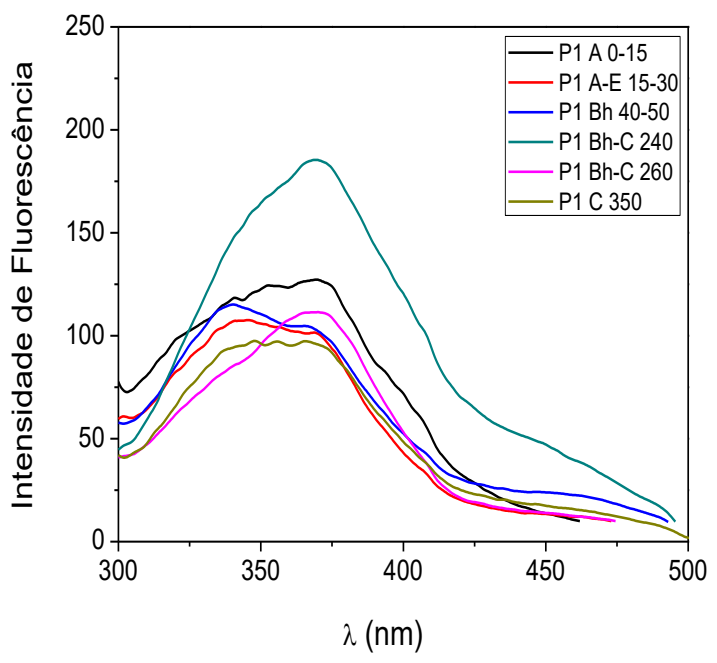

(b)

Fonte: Autoria Própria.

Figura 5.II.24: Espectros de Fluorescência bidimensional utilizando a metodologia proposta por Kalbitz et al. (1999) para as amostras de (a) ácido húmico e (b) ácido fúlvico do Espodossolo Hidromórfico (P2).

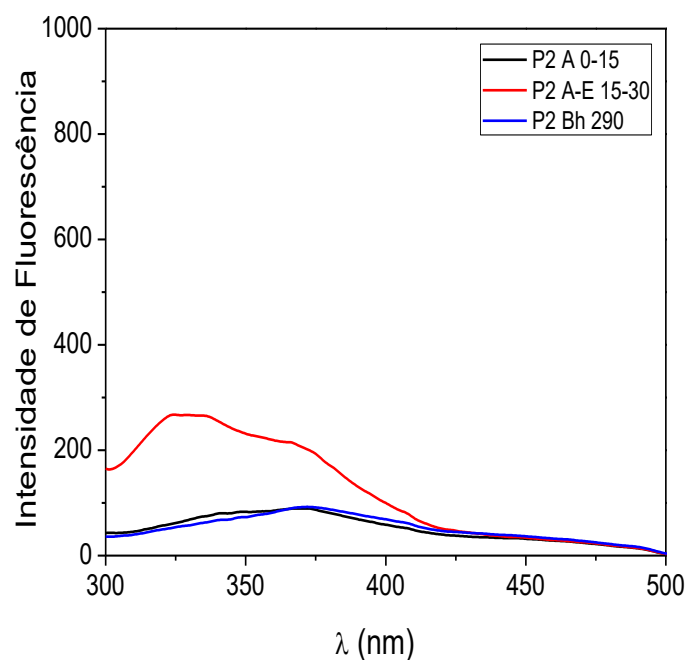

(a)

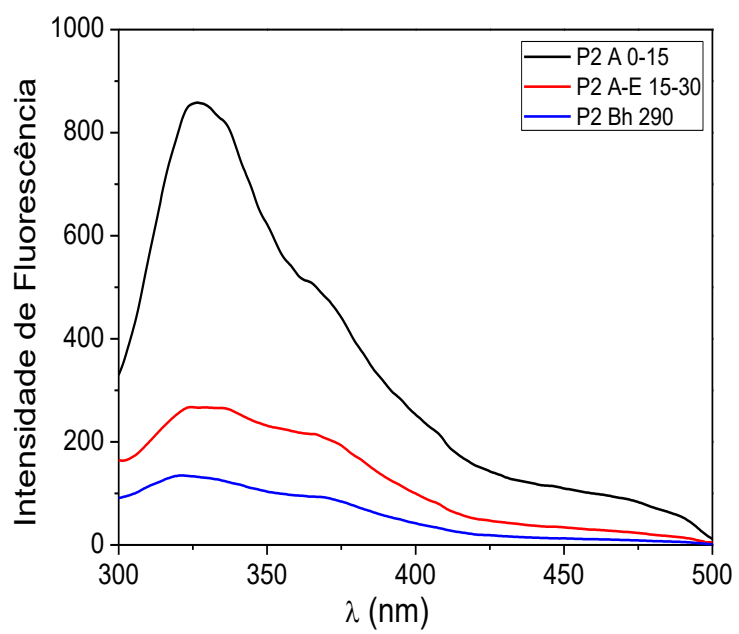

(b)

Fonte: Autoria Própria. 
ANEXO - D: Espectros de fluorescência bidimensional empregando a Espectroscopia de Fluorescência Molecular

Figura 5.II.25: Espectros de Fluorescência bidimensional utilizando a metodologia proposta por Kalbitz et al. (1999) para as amostras de (a) ácido húmico e (b) ácido fúlvico do Espodossolo Hidromórfico (P3).

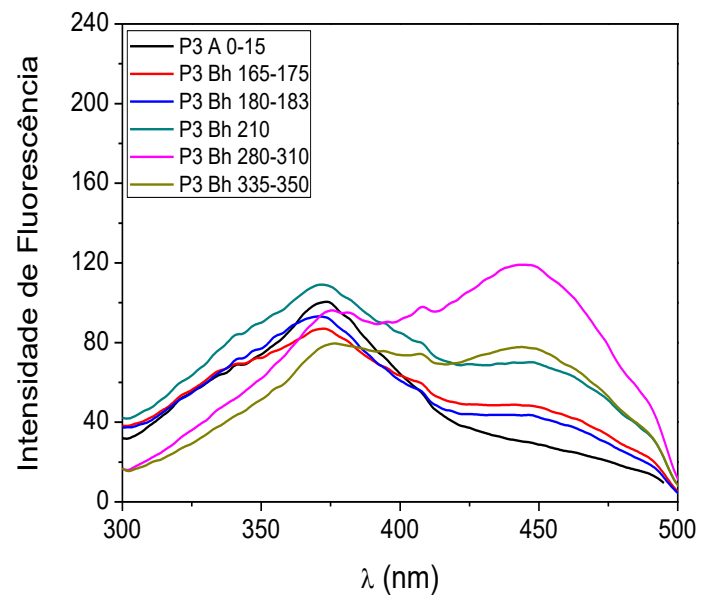

(a)

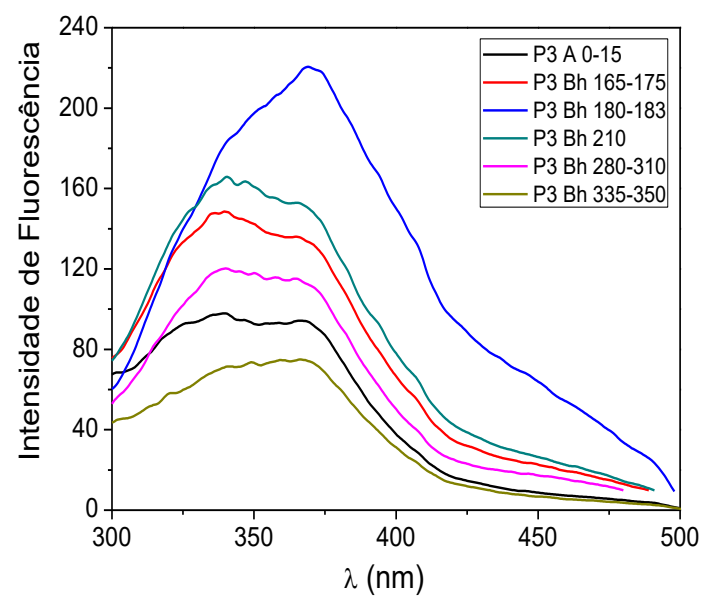

(b)

Fonte: Autoria Própria.

Figura 5.II.26: Espectros de Fluorescência bidimensional utilizando a metodologia proposta por Kalbitz et al. (1999) para as amostras de (a) ácido húmico e (b) ácido fúlvico do Espodossolo Bem Drenado (P4).

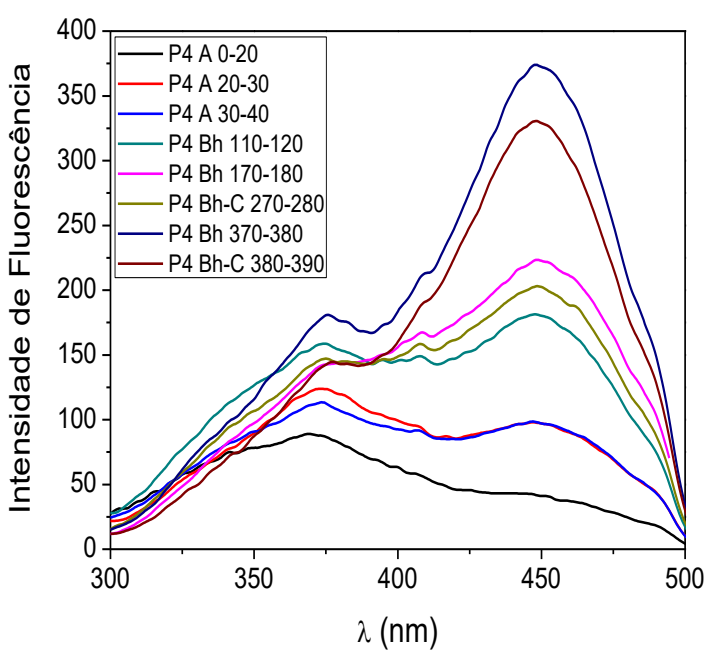

(a)

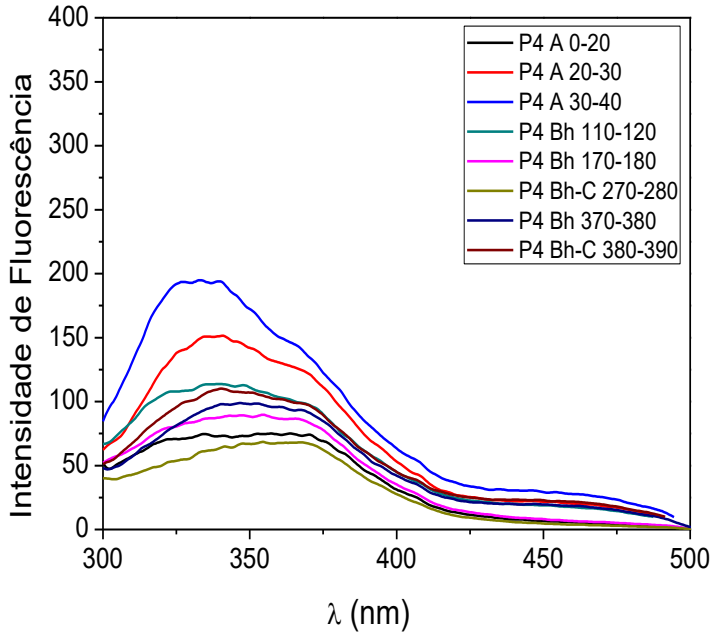

(b)

Fonte: Autoria Própria. 
ANEXO - D: Espectros de fluorescência bidimensional empregando a Espectroscopia de Fluorescência Molecular

Figura 5.II.27: Espectros de Fluorescência bidimensional utilizando a metodologia proposta por Milori et al. (2002) para as amostras de (a) ácido húmico e (b) ácido fúlvico do Espodossolo Hidromórfico (P1).

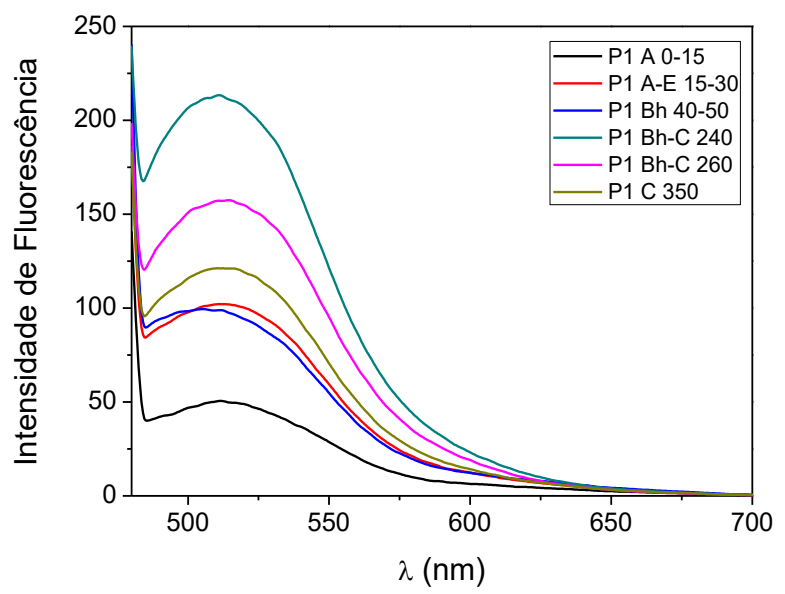

(a)

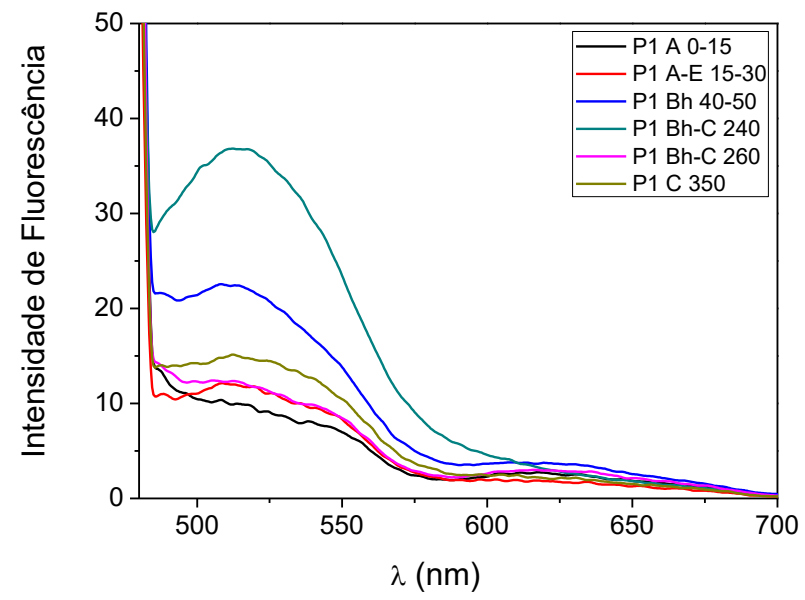

(b)

Fonte: Autoria Própria.

Figura 5.II.28: Espectros de Fluorescência bidimensional utilizando a metodologia proposta por Milori et al. (2002) para as amostras de (a) ácido húmico e (b) ácido fúlvico do Espodossolo Hidromórfico (P2).

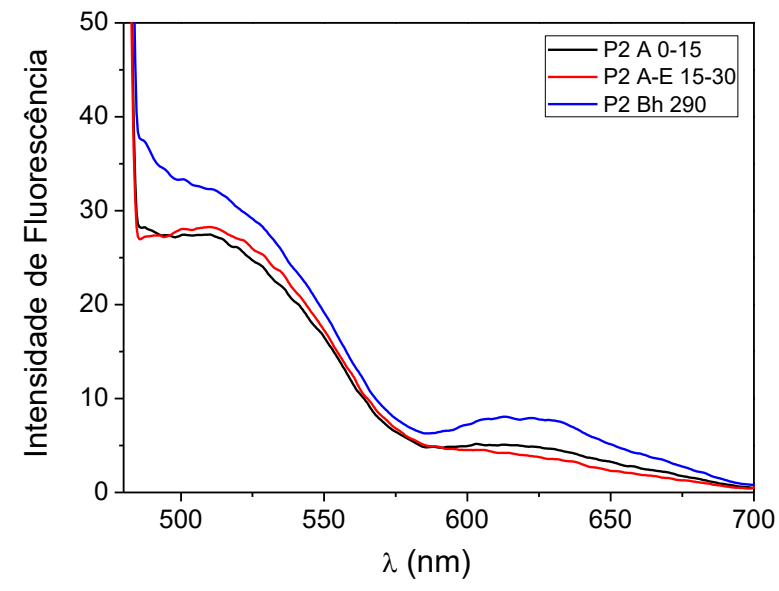

(a)

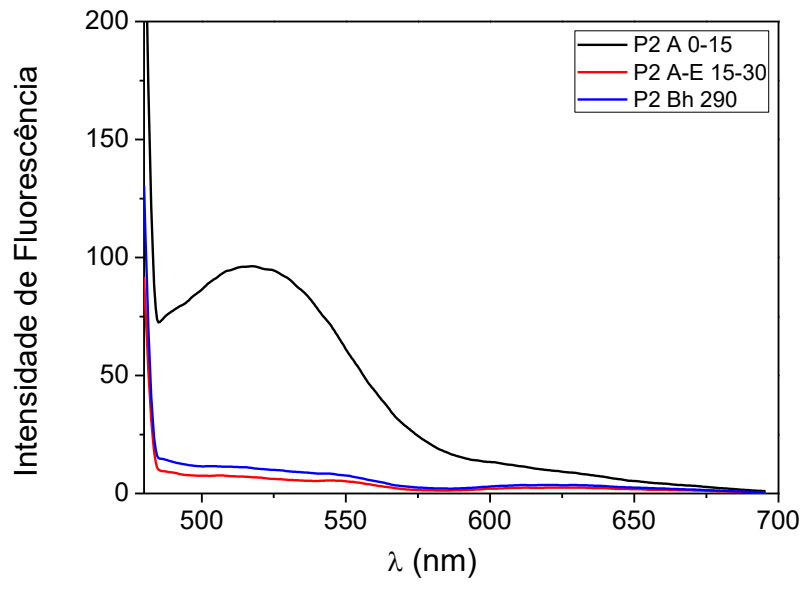

(b)

Fonte: Autoria Própria. 
ANEXO - D: Espectros de fluorescência bidimensional empregando a Espectroscopia de Fluorescência Molecular

Figura 5.II.29: Espectros de Fluorescência bidimensional utilizando a metodologia proposta por Milori et al. (2002) para as amostras de (a) ácido húmico e (b) ácido fúlvico do Espodossolo Hidromórfico (P3).

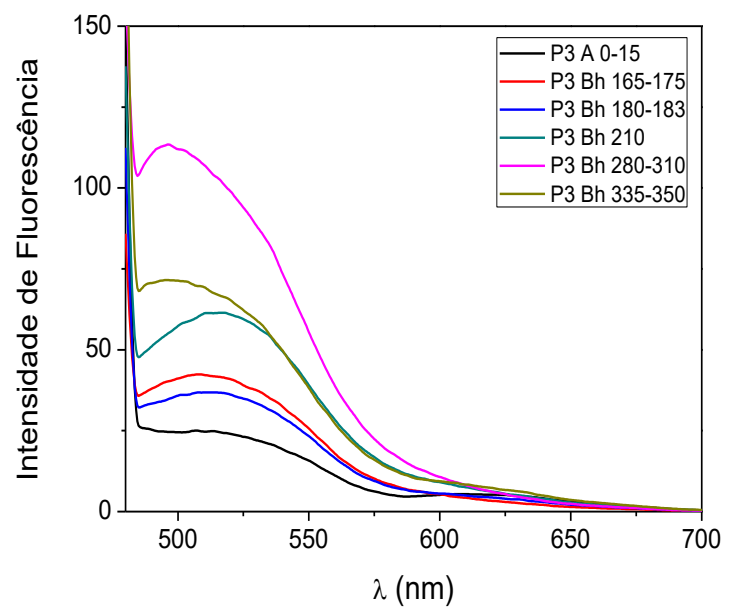

(a)

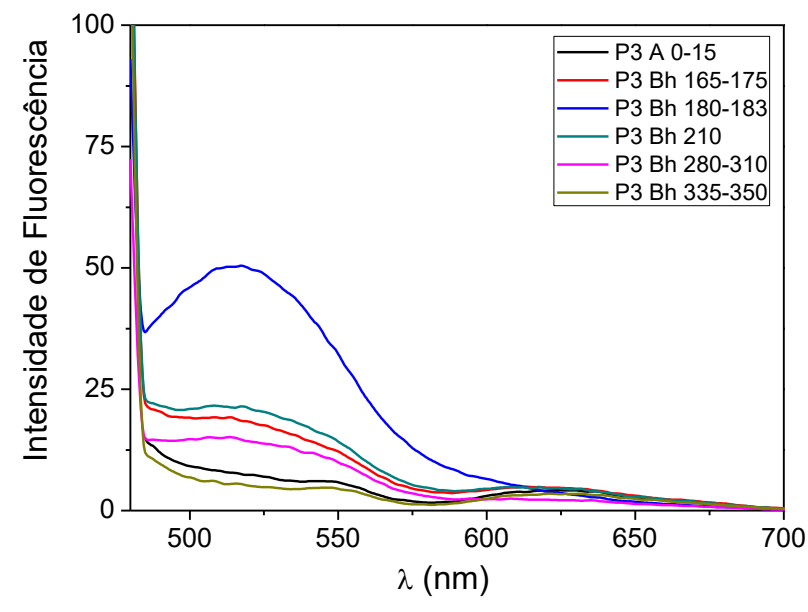

(b)

Fonte: Autoria Própria.

Figura 5.II.30: Espectros de Fluorescência bidimensional utilizando a metodologia proposta por Milori et al. (2002) para as amostras de (a) ácido húmico e (b) ácido fúlvico do Espodossolo Bem Drenado (P4).

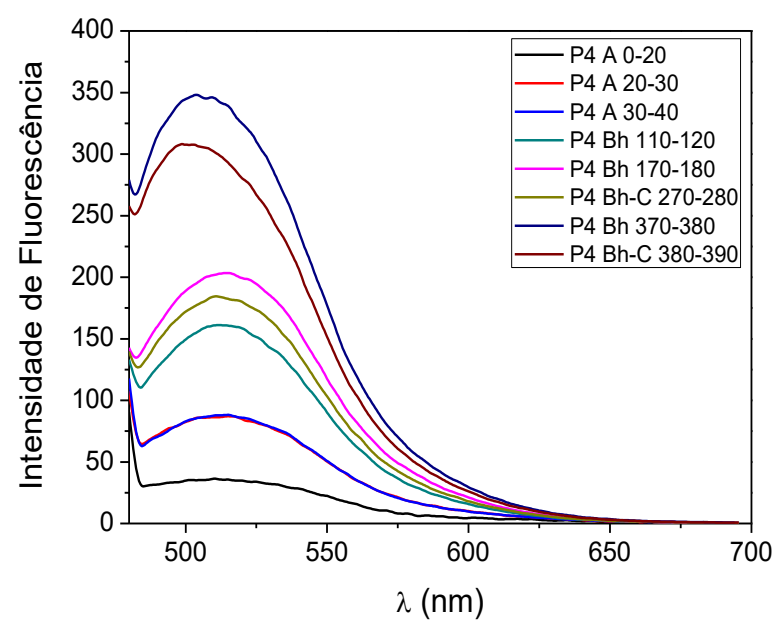

(a)

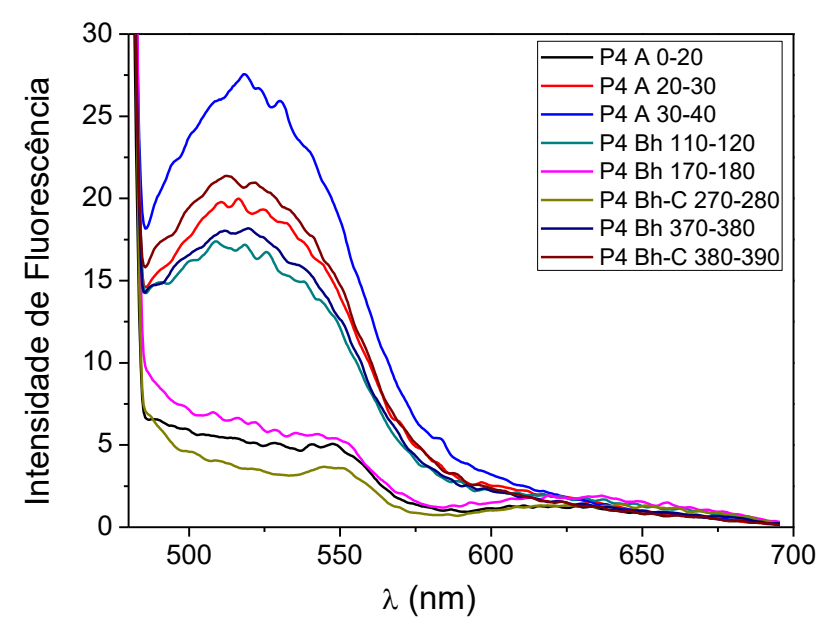

(b)

Fonte: Autoria Própria. 


\section{Anexos 2017}

ANEXO - E: Espectros de Fluorescência Tridimensional empregando a Espectroscopia de Fluorescência Molecular

Figura 5.II.37: Espectros na modalidade emissão-excitação para as amostras de ácido húmico do Espodossolos Hidromórfico (P2) para as diferentes profundidades: (a) P2 A 0-15, (b) P2 A-E 15-30 e (c) P2 Bh 290.
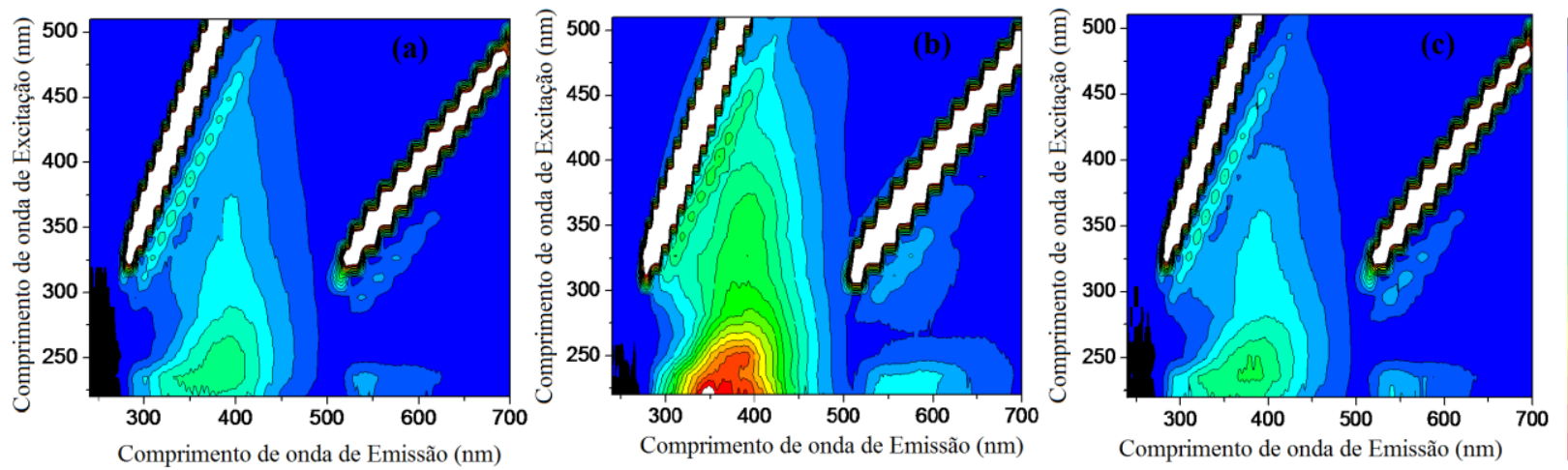

Fonte: Autoria Própria.

Figura 5.II.38: Espectros na modalidade emissão-excitação para as amostras de ácido fúlvico do Espodossolos Hidromórfico (P2) para as diferentes profundidades: (a) P2 A 0-15, (b) P2 A-E 15-30 e (c) P2 Bh 290.
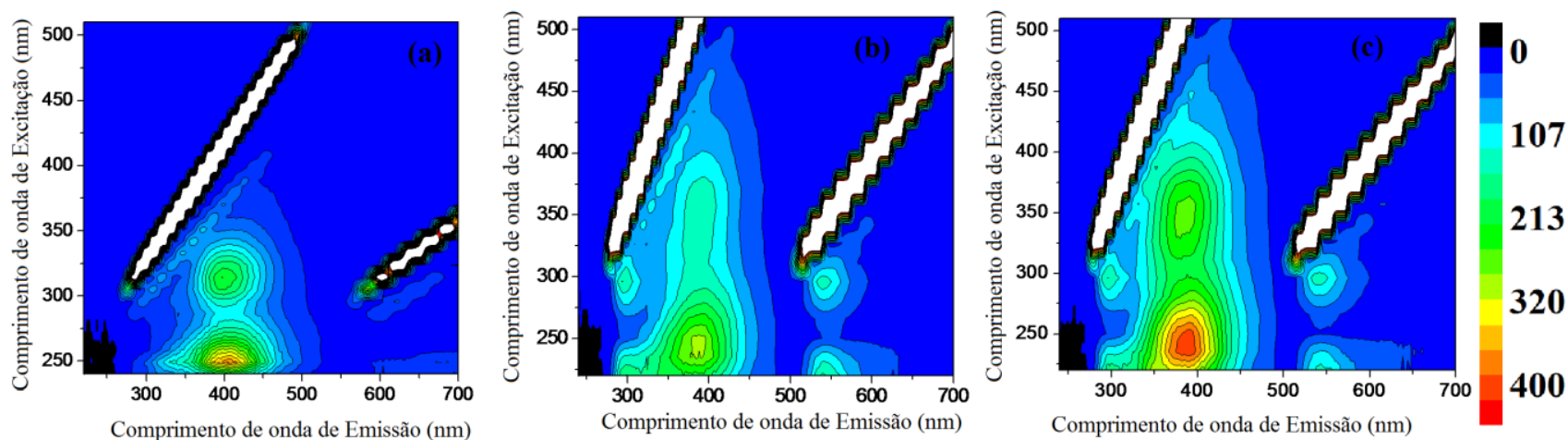

Fonte: Autoria Própria.

Figura 5.II.39: Espectros na modalidade emissão-excitação para as amostras de Humina do Espodossolos Hidromórfico (P2) para as diferentes profundidades: (a) P2 A 0-15, (b) P2 A-E 15-30 e (c) P2 Bh 290.
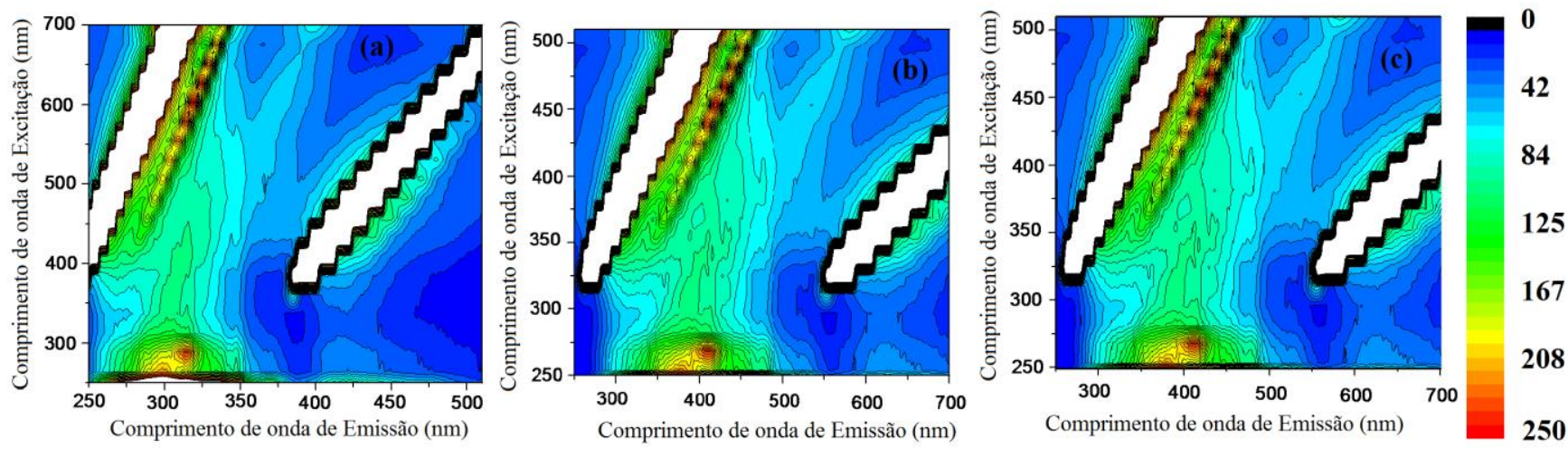

Fonte: Autoria Própria. 


\section{Anexos 2017}

ANEXO - E: Espectros de Fluorescência Tridimensional empregando a Espectroscopia de Fluorescência Molecular

Figura 5.II.40: Espectros na modalidade emissão-excitação para as amostras de Ácido Húmico do Espodossolos Hidromórfico (P3) para as diferentes profundidades: (a) P3 A 0-15, (b) P3 Bh 165-175, (c) P3 Bh 180-183, (d) P3 Bh 210, (e) P3 Bh 280-310 e (f) P3 Bh 335-350.
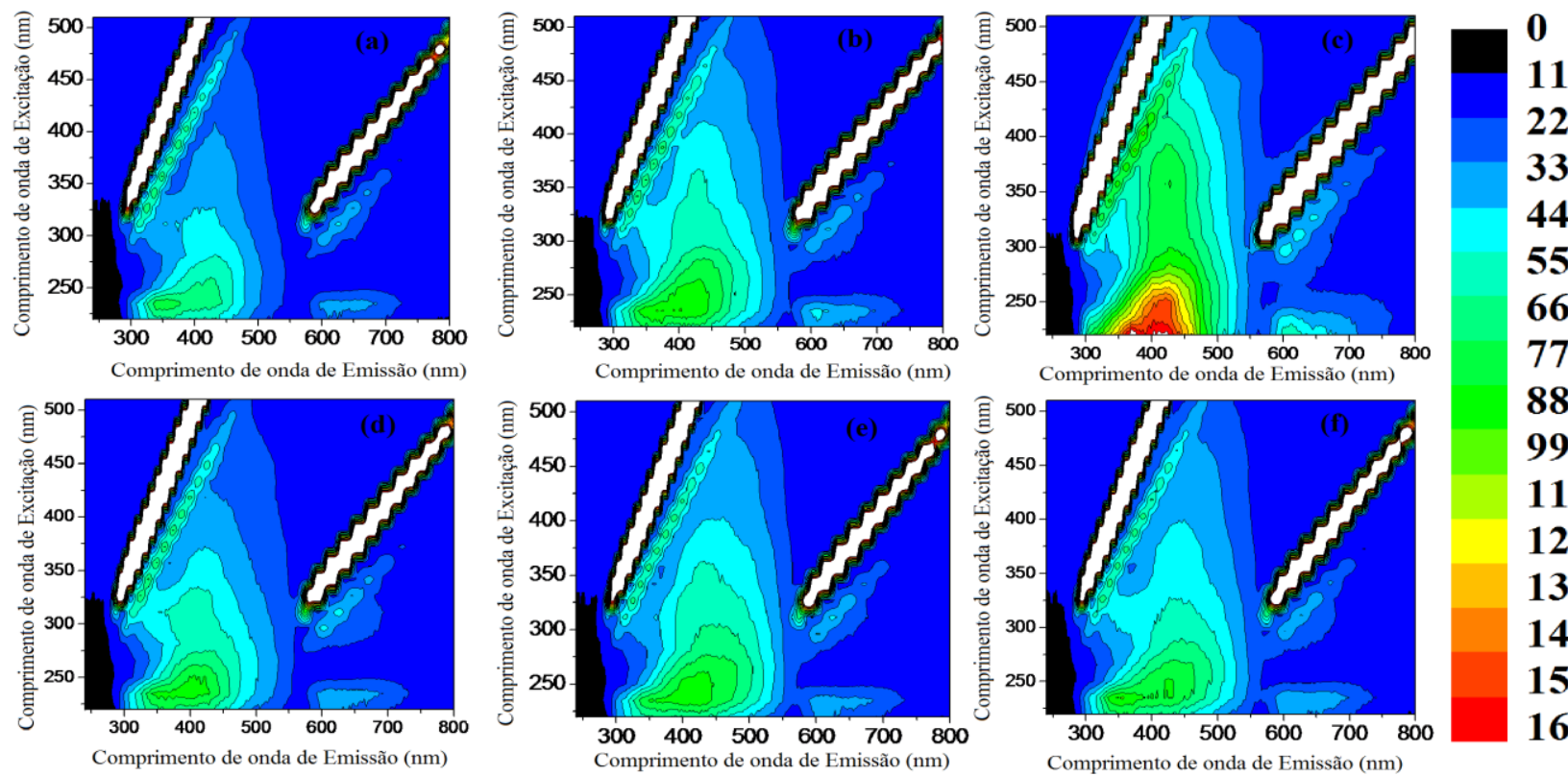

88

Fonte: Autoria Própria.

Figura 5.II.41: Espectros na modalidade emissão-excitação para as amostras de Ácido Fúlvico do Espodossolos Hidromórfico (P3) para as diferentes profundidades: (a) P3 A 0-15, (b) P3 Bh 165-175, (c) P3 Bh 180-183, (d) P3 Bh 210, (e) P3 Bh 280-310 e (f) P3 Bh 335-350.
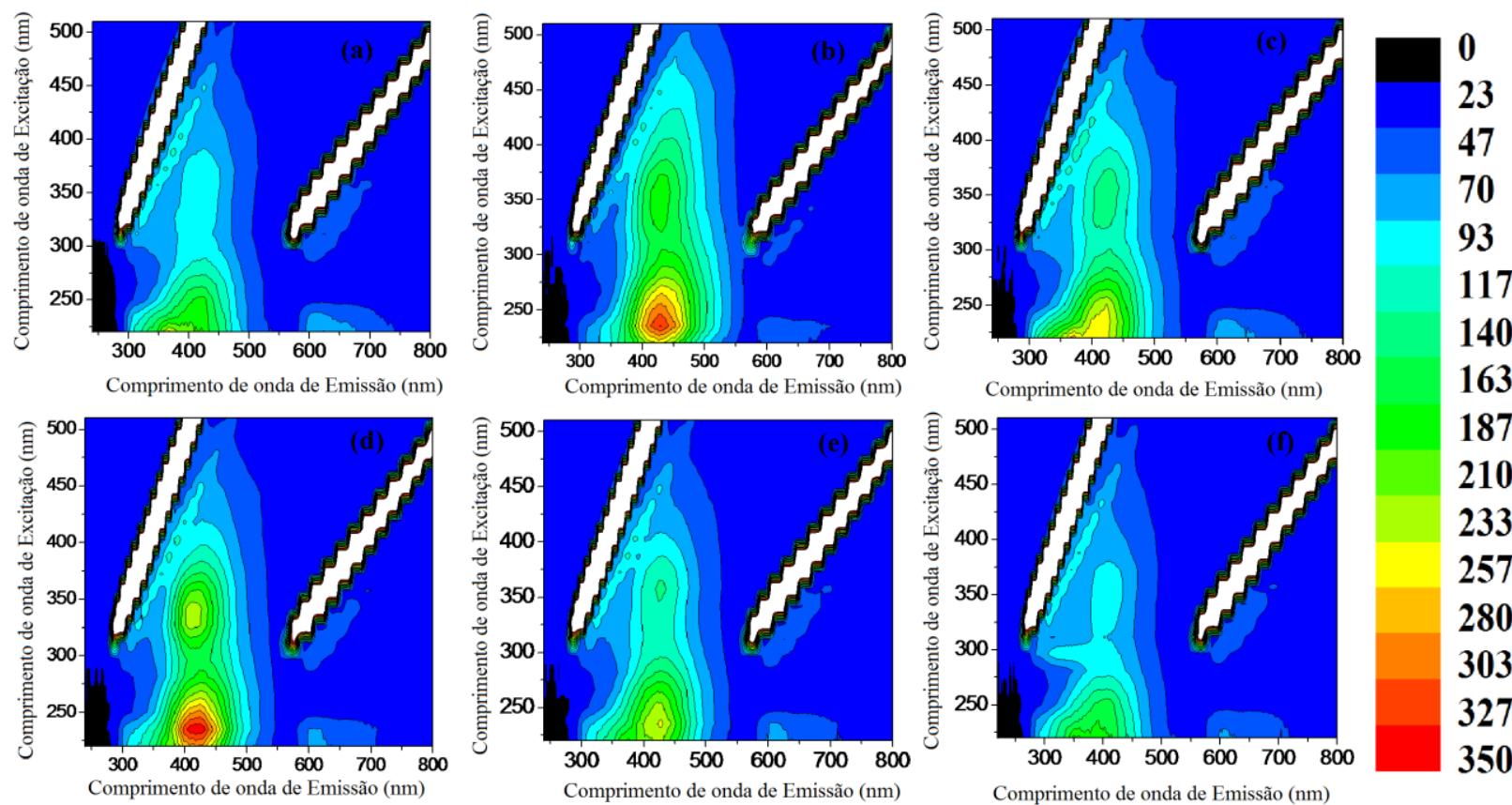

Fonte: Autoria Própria. 


\section{Anexos 2017}

ANEXO - E: Espectros de Fluorescência Tridimensional empregando a Espectroscopia de Fluorescência Molecular

Figura 5.II.42: Espectros na modalidade emissão-excitação para as amostras de Humina do Espodossolos Hidromórfico (P3) para as diferentes profundidades: (a) P3 A 0-15, (b) P3 Bh 165-175, (c) P3 Bh 180-183, (d) P3 Bh 210, (e) P3 Bh 280-310 e (f) P3 Bh 335-350.
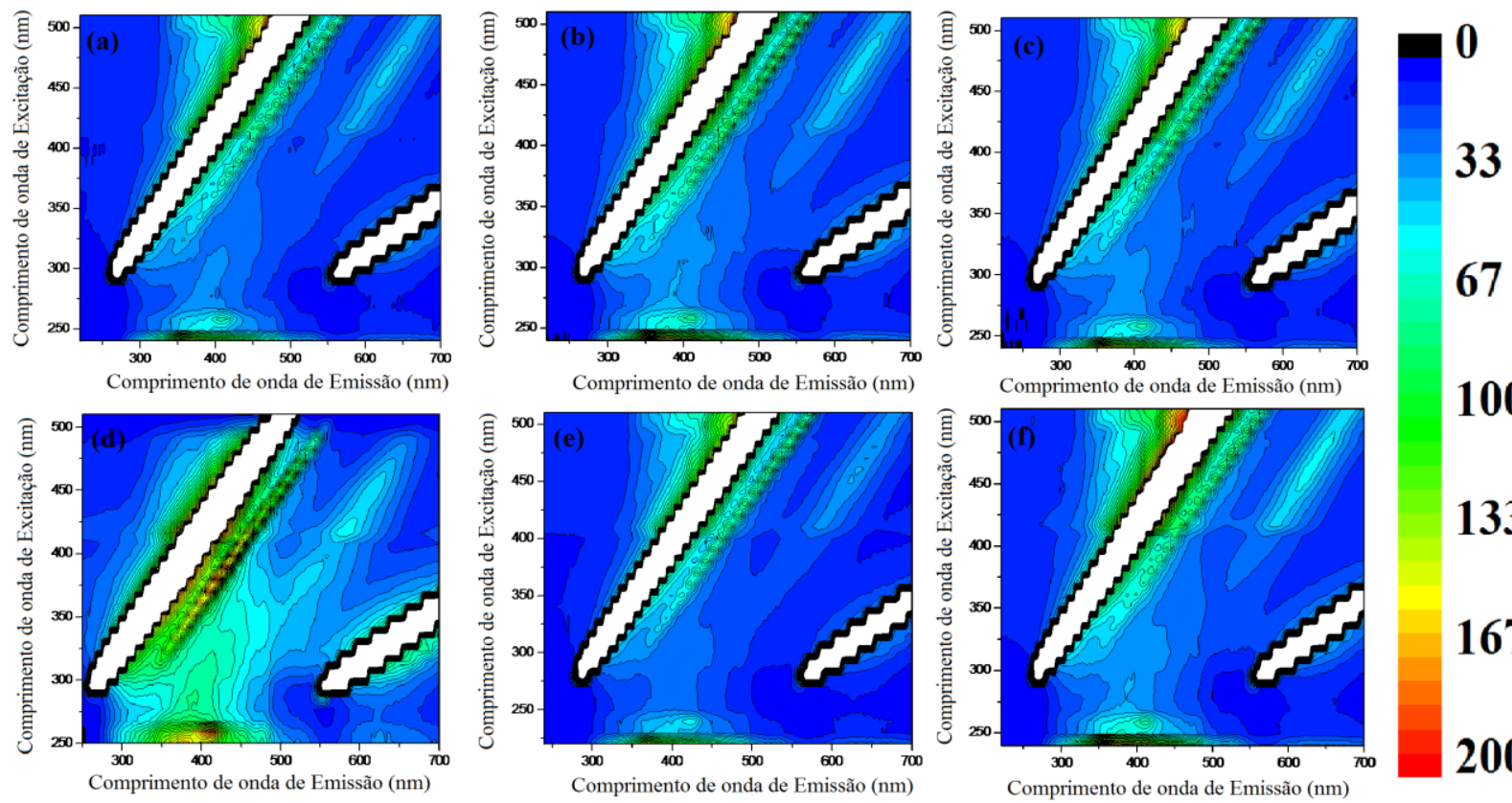

100

133

167

200

Fonte: Autoria Própria.

Figura 5.II.43: Espectros na modalidade emissão-excitação para as amostras de Ácido Húmcio do Espodossolos Bem Drenado (P4) para as diferentes profundidades: (a) P4 A 0-20, (b) P4 A 20-30, (c) P4 A 30-40, (d) P4 Bh 110-120, (e) P4 Bh 170-180, (f) P4 Bh-C 270-280, (g) P4 Bh 370-380 e (h) P4 Bh-C 380-390.
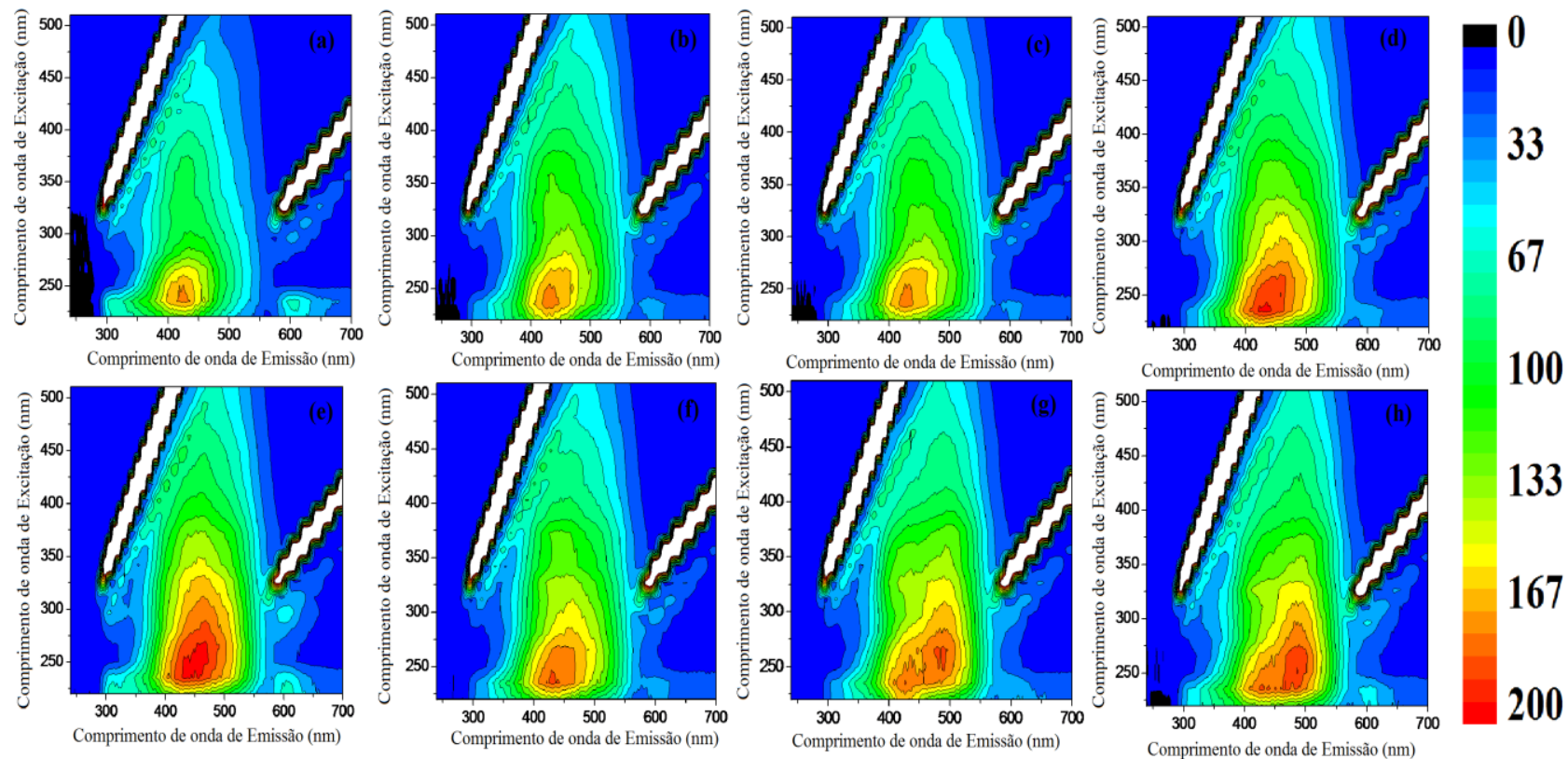

Fonte: Autoria Própria. 


\section{Anexos 2017}

ANEXO - E: Espectros de Fluorescência Tridimensional empregando a Espectroscopia de Fluorescência Molecular

Figura 5.II.44: Espectros na modalidade emissão-excitação para as amostras de Ácido Fúlvico do Espodossolos Bem Drenado (P4) para as diferentes profundidades: (a) P4 A 0-20, (b) P4 A 20-30, (c) P4 A 30-40, (d) P4 Bh 110-120, (e) P4 Bh 170-180, (f) P4 Bh-C 270-280, (g) P4 Bh 370-380 e (h) P4 Bh-C 380-390.
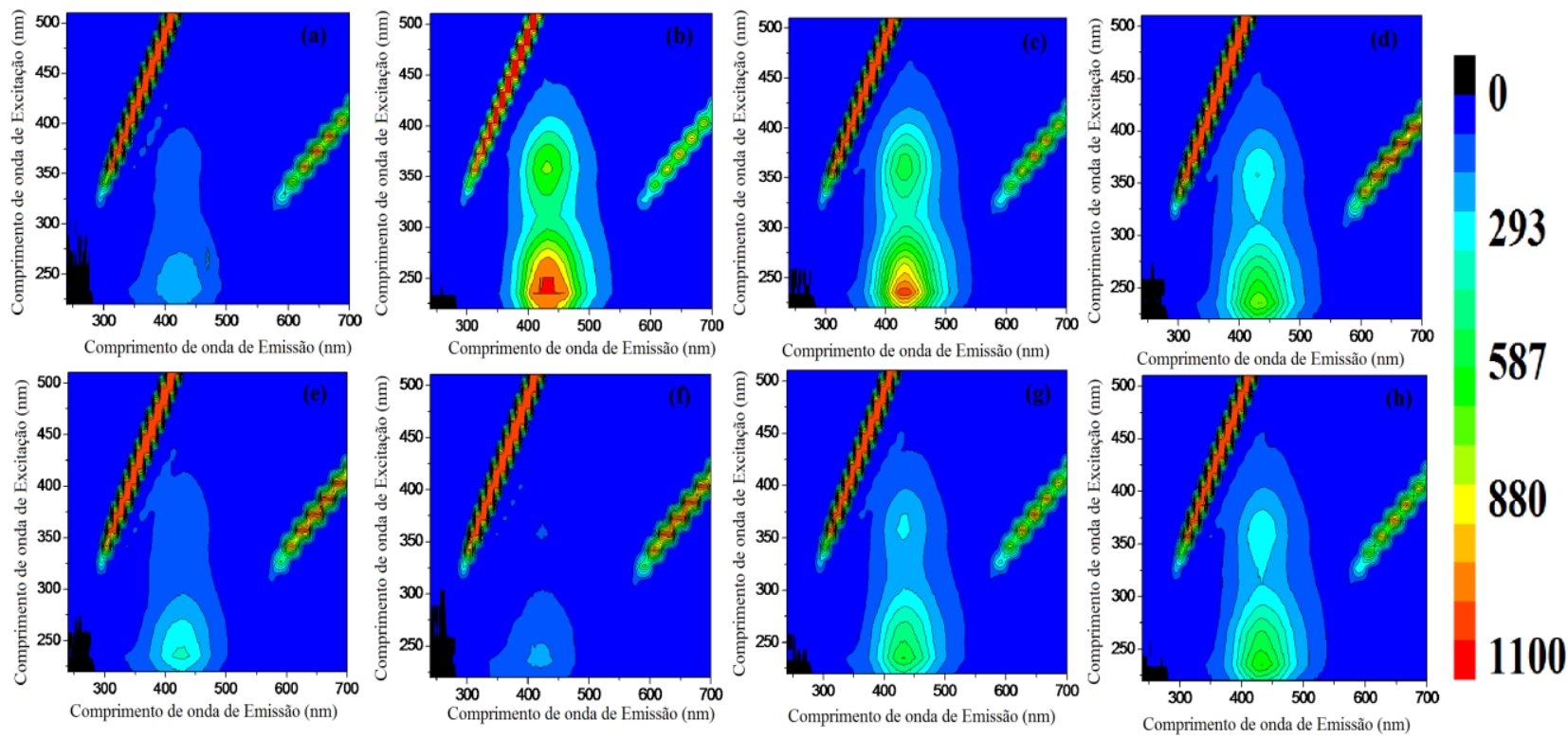

Fonte: Autoria Própria.

Figura 5.II.45: Espectros na modalidade emissão-excitação para as amostras de Humina do Espodossolos Bem Drenado (P4) para as diferentes profundidades: (a) P4 A 0-20, (b) P4 A 20-30, (c) P4 A 30-40, (d) P4 Bh 110120, (e) P4 Bh 170-180, (f) P4 Bh-C 270-280, (g) P4 Bh 370-380 e (h) P4 Bh-C 380-390.
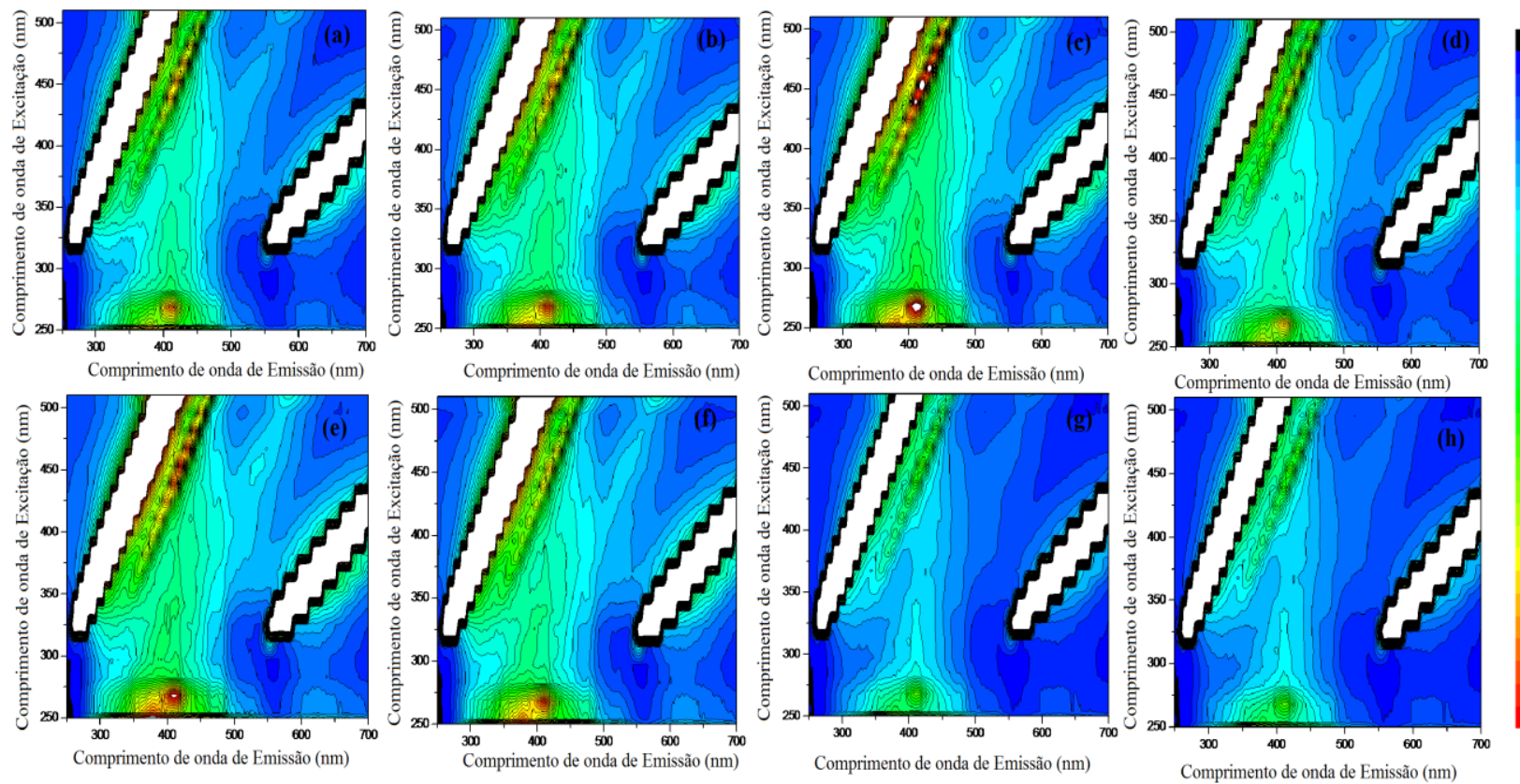

Fonte: Autoria Própria. 


\section{ANEXO - F: Publicações}

Science of the Total Environment 537 (2015) 152-158

\section{The importance of humin in soil characterisation: A study on Amazonian} soils using different fluorescence techniques

Amanda Maria Tadini a,b,*, Gustavo Nicolodelli ${ }^{a}$, Stephane Mounier ${ }^{c}$,

Célia Regina Montes ${ }^{\mathrm{d}}$, Débora Marcondes Bastos Pereira Milori ${ }^{\mathrm{a}}$

a Embrapa Agricultural Instrumentation, São Carlos, SP, Brazil

' Institute of Chemistry of São Carlos, University of São Paulo, São Carlos, SP, Brazil

c Institute of Chemistry of São Carlos, University of Säo Paulo, São Carlos, SP, Brazil
${ }^{2}$ Laboratoire PROTEE, EA3819, Université de Toulon, CS 60584, 83041 Toulon CEDEX 9, France

'Laboratoire PROTEE, EA3819, Université de Toulon, CS 60584, 83041 Toulon CEDEX 9, France
"Centro de Energia Nuclear na Agricultura and NUPEGEL, University of São Paulo, Piracicaba, SP, Brazil

H I G H L I G H T S

- Two fluorophores were observed in the structures of humin and the whole soil

- The fluorescence of the soil is strongly related to the fluorescence of the humin. - Humin fraction can represent $80-93 \%$ of fraction of the Amazonian SOM.

\section{A R T I C L E I N F O}

\section{Article history:}

Received 29 April 2015

Received in revised form 24 July 2015

Accepted 25 July 2015

Available online $x x x x$

Editor: D. Barcelo

\section{Keywords:}

Humin

Hum

Humification

Humification
Fluorescence

CP/PARAFAC

\section{GRA P H I CA L A B S T R A C T}

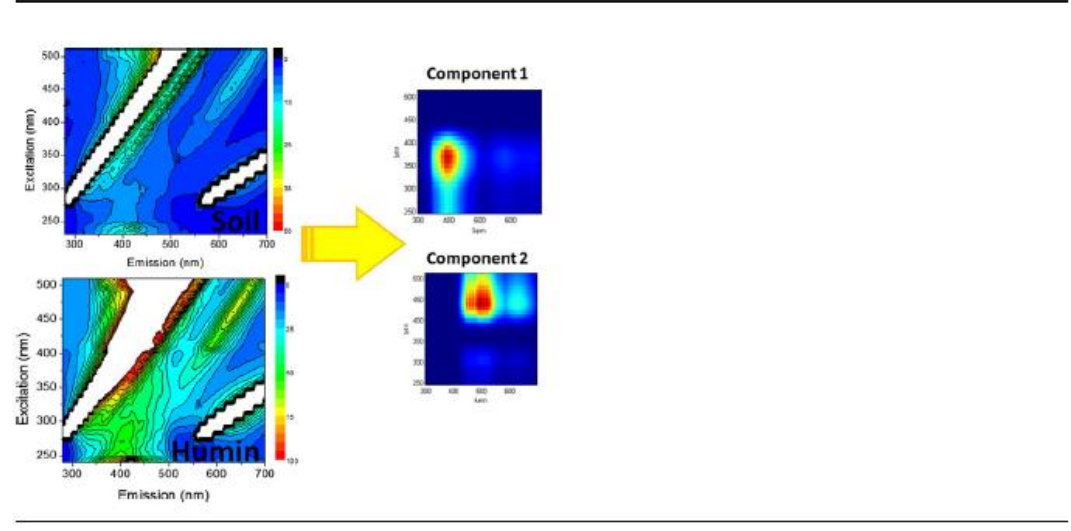

\section{A B S T R A C T}

Soil organic matter (SOM) is a complex mixture of molecules with different physicochemical properties, with humic substances (HS) being the main component as it represents around $20-50 \%$ of SOM structure. Soil of the Amazon region is considered one of the larger carbon pools of the world; thus, studies of the humic fractions are important for understanding the dynamics of organic matter $(\mathrm{OM})$ in these soils. The aim of this study was to use laser-induced fluorescence spectroscopy (UFS) and a combination of excitation-emission matrix (EEM) fluorescence with Parallel Factor Analysis (CP/PARAFAC) to assess the characteristics of humin (HU) extracted from Amazonian soils. The results obtained using LFS showed that there was an increasing gradient of humification degree with depth, the deeper horizon presenting a higher amount of aromatic groups in the structure of HU. From the EEM, the contribution of two fluorophores with similar behaviour in the structures of $\mathrm{HU}$ and whole soil was assessed. Additionally, the results showed that the $\mathrm{HU}$ fraction might represent a larger fraction of SOM than previously thought: about $80-93 \%$ of some Amazon soils. Therefore, HU is an important humic fraction, thus indicating its role in environmental analysis, mainly in soil analysis.

(C) 2015 Elsevier B.V. All rights reserved.

\footnotetext{
- Corresponding author at: Embrapa Agricultural Instrumentation, São Carlos, SP, Brazil. E-mail address: amandatadini@hotmail.com (A.M. Tadini).
} 


\title{
ANEXO - F: Publicações
}

\section{Characterization of Organic Matter in Spodosol Amazonian by Fluorescence Spectroscopy}

\author{
Amanda M. Tadini, Houssam Hajjoul, Gustavo Nicolodelli, Stéphane Mounier, Célia R. Montes, Débora M. B. P.
} Milori

\begin{abstract}
Soil organic matter (SOM) plays an important role in maintaining soil productivity and accounting for the promotion of biological diversity. The main components of the SOM are the humic substances which can be fractionated according to its solubility in humic acid (HA), fulvic acids (FA) and humin (HU). The determination of the chemical properties of organic matter as well as its interaction with metallic species is an important tool for understanding the structure of the humic fractions. Fluorescence spectroscopy has been studied as a source of information about what is happening at the molecular level in these compounds. Specially, soils of Amazon region are an important ecosystem of the planet. The aim of this study is to understand the molecular and structural composition of HA samples from Spodosol of Amazonia using the fluorescence Emission-Excitation Matrix (EEM) and Time Resolved Fluorescence Spectroscopy (TRFS). The results showed that the samples of HA showed two fluorescent components; one has a more complex structure and the other one has a simpler structure, which was also seen in TRFS through the evaluation of each sample lifetime. Thus, studies of this nature become important because it aims to evaluate the molecular and structural characteristics of the humic fractions in the region that is considered as one of the most important regions in the world, the Amazon.
\end{abstract}

Keywords-Amazonian soil, characterization, fluorescence, humic acid, lifetime.

\section{INTRODUCTION}

$T_{1}$ HE Amazon forest provides important services to humanity, such as high biodiversity, climate regulation, carbon sequestration, and regulation of water cycles and nutrients. Therefore, Amazon has become an area for the research mainly related to the area of the soil in order to understand its soil development process in the region and possible consequences of land use change and occupation of soils. The main soil formations found in the Negro River basin are Oxisols, Podzols, and hydromorphic soils. Podzols are

Amanda Maria Tadini, $\mathrm{PhD}$ student at the Institute of Chemistry of São Carlos, University of São Paulo (USP); Brazil and Embrapa Instrumentation, São Carlos, SP, Brazil (corresponding author; e-mail: amandatadini@hotmail.com).

Houssam Hajjoul, $\mathrm{PhD}$, Stéphane Mounier, Professor, in Laboratory of 'Processus de Transferts et d'Echanges dans l'Environnement', University of Toulon, CS 60584, 83041 Toulon, Cedex 9, France (e-mail: houssam.hajjoul@gmail.com, mounier@univ-tln.fr).

Gustavo Nicolodelli, Post-doctoral fellow in Optics and Photonics Laboratory, Instrumentation Embrapa, São Carlos, SP; Brazil (email: gunicolodelli@hotmail.com)

Célia Regina Montes, Professor at the Center for Nuclear Energy in Agriculture and NUPEGEL, University of São Paulo, Piracicaba, SP, Brazil (e-mail: crmlauar@usp.br).

Débora Marcondes Bastos Pereira Milori, Researcher at Embrapa Instrumentation, São Carlos, SP, Brazil (e-mail: debora.milori@embrapa.br). soils that have a strong vertical differentiation diagnosed by the presence of spodic horizon $(\mathrm{Bh})$, which accumulates organic matter [1].

SOM plays an important role in environmental sustainability and participation in the formation and transformation processes of soil, especially in the carbon cycle. The main components of the SOM are humic substances (HS), having well defined physical and chemical characteristics and are composed of fractioned HA. FA, and $\mathrm{HU}$ according to their solubility. Thus, understanding the dynamics of SOM is essential for assessing the quality and capacity of the soil to resist the changes in their physical and chemical properties according to the weather conditions and the nature of the source material [2].

The amount of organic carbon stored in the surface layer $(0$ to $1.0 \mathrm{~m}$ ) in hydromorphic podzols the upper Rio Negro is $87 \pm 7 \mathrm{~kg} \mathrm{~m}^{-2}$ for all soils, and corresponds to $14 \pm 1 \mathrm{Pg}$ of the Carbon [3]. SOMs in these soils are not homogeneous, and studies to evaluate the dynamics of this matter are important mainly in this ecosystem that is considered one of the most important carbon sinks in the world [4]

The determination of the optical properties of SOM is an important process for understanding their structural fractions. The use of this technique can contribute to analyze the composition and interactions of HS which reflect on the future changes of these substances with changes in land uses. Fluorescence EEM is a selective and sensitive spectroscopic technique which allows a simple assembly or a mixture of fluorescent components present in humic fractions which can be measured, thereby providing a digital sample print [5], [6]. Furthermore, the EEM spectra can be used for the qualitative and quantitative characterization of fluorescent organic matter when combined with the advanced multivariate statistical techniques such as Parallel Factor Analysis (CP/PARAFAC), which can decompose the signal complex of fluorescence spectra into simple components.

EEM-CP/PARAFAC is a potentially useful technique in the evaluation of complex samples such as HS. This technique enables the evaluation of the decomposition of fluorescent components, regardless of complex formed in EEM, which represent groups called fluorescent components [5]-[8]

Suppression fluorescence, also known as quenching analysis, is a process which decreases the fluorescence intensity of a sample, which can result in decay due to molecular interactions [8]. These interactions include reactions in the excited state, molecular rearrangements, energy transfer, complex formation in the ground state and the collision energy 
ANEXO - F: Publicações

Science of the Total Environment 613-614 (2018) 160-167

\begin{tabular}{cc} 
Contents lists available at ScienceDirect \\
ELSEVIER & Science of the Total Environment \\
\hline
\end{tabular}

Soil organic matter in podzol horizons of the Amazon region: Humification, recalcitrance, and dating

Amanda M. Tadini a,b,f,*, Gustavo Nicolodelli a , Giorgio S. Senesi ${ }^{c}$, Débora A. Ishida ${ }^{\mathrm{d}}$, Célia R. Montes ${ }^{\mathrm{e}}$, Yves Lucas ${ }^{\mathrm{f}}$, Stéphane Mounier ${ }^{\mathrm{f}}$, Francisco E.G. Guimarães ${ }^{\mathrm{g}}$, Débora M.B.P. Milori ${ }^{\text {a }}$

a Embrapa Instrumentação, São Carlos, SP, Brazil

b Instituto de Química de São Carlos, Universidade de São Paulo, São Carlos, SP, Brazil

c CNR - Institute of Nanotechnology (NANOTEC), PLasMI Lab, Bari, Italy

${ }^{a}$ Instituto de Energia e Ambiente e Núcleo de Pesquisa em Geoquímica e Geofísica da Litosfera, Universidade de São Paulo, Piracicaba, SP, Brazil

e Centro de Energia Nuclear na Agricultura e Núcleo de Pesquisa em Geoquímica e Geofisica da Litosfera, Universidade de São Paulo, Piracicaba, SP, Brazil

' Laboratoire PROTEE, Université de Toulon - CS 60584, 83041 TOULON, CEDEX 9, France

${ }^{\mathrm{g}}$ Instituto de Fisica de São Carlos, Universidade de São Paub, São Carlos, SP, Brazil

\section{H I G H L I G H T S}

- Structural variation in the humic acids for the depth profile.

- Humic acids originated from lignin-

derived compounds.

- Lignin can accumulate in some Bh horizons.

- Amazonian podzols there are four kinds of the organic matter.

- Humification process has not direct association with the dating of organic matter.
GRAPHICAL ABSTRACT

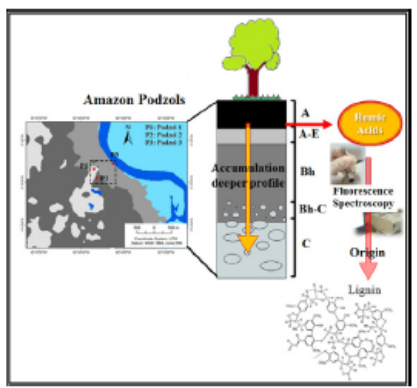

